\title{
Threatened Primates
}

of Africa

The IUCN Red Data Book -1)
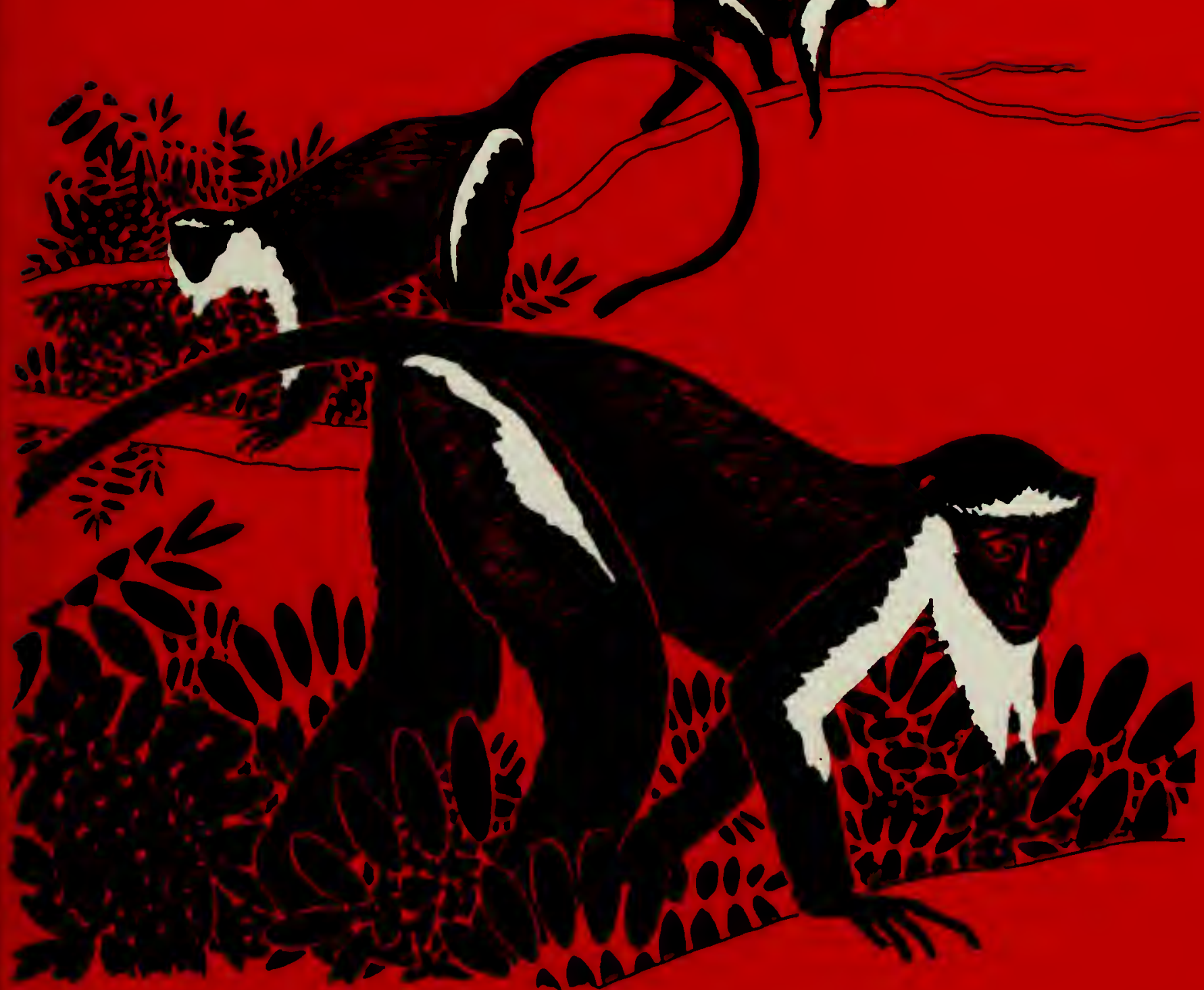

Digitized by the Internet Archive in 2010 with funding from UNEP-WCMC, Cambridge 

THREATENED PRIMATES OF AFRICA THE IUCN RED DATA BOOK 


\section{IUCN}

IUCN (International Union for Conservation of Nature and Natural Resources) is a membership organisation comprising governments, non-governmental organisations (NGOs), research institutions, and conservation agencies, whose objective is to promote and encourage the protection and sustainable use of living resources.

Founded in 1948, IUCN has nearly 600 members representing 116 countries. Its six Commissions comprise a global network of experts on threatened species, protected areas, ecology, environmental planning, environmental law, and environmental education. Its thematic programmes include tropical forests, wetlands, marine ecosystems, plants, oceanic islands, the Sahel, Antarctica, and population and sustainable development.

\section{THE IUCN CONSERVATION MONITORING CENTRE}

The Conservation Monitoring Centre (CMC) is the division of IUCN that provides an information service to the Union, its members, and the conservation and development communities. CMC has developed an integrated and cross-referenced global database on animals, plants and habitats of conservation concern, on protected areas throughout the world, and on the international trade in wildlife species and products. CMC produces a wide variety of specialist outputs and reports based on the analysis of this data, including such major publications as the Red Data Books and Protected Areas Directories which are now recognised as the authoritative reference works in their field.

Other IUCN Centres focus on Environmental Law, and Conservation for Development. Collectively, this information and expertise is used to assist IUCN and its members to develop conservation policy and implement programmes, and to promote a greater awareness of the need for sound conservation practice by the international development community.

Should you wish to consult these services please contact:

The IUCN Secretariat, World Conservation Centre, Avenue du Mont-Blanc, CH-1196 Gland, Switzerland

\section{UNEP}

The United Nations Environment Programme (UNEP) is a Secretariat within the United Nations which was established to serve as a focal point for environmental action and co-ordination within the UN system.

\section{GEMS}

The Global Environment Monitoring System (GEMS), co-ordinated by UNEP, is a collective effort of the world community to acquire, through global monitoring, the data which are needed for rational management of the environment. Monitoring activities fall into five major programmes: climate-related monitoring, long range transport of air pollutants, health-related monitoring, oceans and terrestrial renewable resources. 


\title{
THREATENED PRIMATES OF AFRICA THE IUCN RED DATA BOOK
}

\author{
Compiled by the \\ IUCN Conservation Monitoring Centre \\ Cambridge U.K.
}

\author{
By \\ Phyllis C. Lee \\ Jane Thornback \\ and \\ Elizabeth L. Bennett
}

1988

IUCN Gland, Switzerland and Cambridge, U.K. 
Published by IUCN, Gland, Switzerland and Cambridge, UK with financial support from the World Wildlife Fund (U.S.) Primate Program.

Prepared in collaboration with the United Nations Environment Programme and the World Wide Fund for Nature.

\section{A CONTRIBUTION TO GEMS - THE GLOBAL ENVIRONMENT MONITORING SYSTEM}
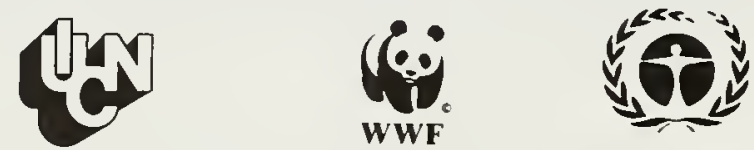

Copyright: 1988 International Union for Conservation of Nature and Natural Resources/United Nations Environment Programme

Reproduction of this publication for educational or other non-commercial purposes is authorised without prior permission from the copyright holder[s].

Reproduction for resale or other commercial purposes is prohibited without the prior written permission of the copyright holder[s].

Citation: Lee, P.C., Thornback, J. and Bennett, E.L. (1988). Threatened Primates of Africa. The IUCN Red Data Book. IUCN Gland, Switzerland and Cambridge, U.K.

ISBN:

Printed by:

Cover illustration:

Typesetting by:

Available from:
2-88032-955-6

Page Bros (Norwich) Ltd. U.K.

Diana Monkeys by: Brian Groombridge

Jo Taylor, IUCN Publications Services Unit

IUCN Publications Services, 219c Huntingdon Road, Cambridge CB3 0DL, UK.

The designations of geographical entities in this book, and the presentation of the material, do not imply the expression of any opinion whatsoever on the part of IUCN, UNEP or other participating organisations concerning the legal status of any country, territory, or area, or of its authorities, or concerning the delimitation of its frontiers or boundaries.

The views of the authors expressed in this publication do not necessarily reflect those of IUCN or other participating organisations. 


\title{
PREFACE
}

With the publication of this volume we see the steady evolution of the Red Data Book approach which in no small part is in response to the steadily changing needs of conservation and the user community.

This volume on primates also reflects the great depth of knowledge that exists for this high profile group of species. The three Authors are to be congratulated on sifting so meticulously the data to provide the succinct and information packed pages. With the ever increasing pressure on primates both by habitat loss and at the other end of the spectrum for biomedical research etc we must have available the latest and indepth research to conserve species by species action plans and programmes, in fact we actually see in this volume the traditional RDB data related to the Action Plans. Research and data are the essential tools for the modern conservation manager, whether of a reserve or a zoo. The essential partnership between the laboratory scientist, the field worker and decision makers is essential for these and all other species to have a long term future. The 14 pages of Black-\&-white photographs help us to realise what beautiful and special creatures the primates are, and why the public at large are concerned for them.

W.W.F. (U.S.) provided the majority of the financial support for the publication costs of this book and the Jersey Wildlife Preservation Trust also provided a contribution.

It is, as usual, the partnership of so many individuals and organisations that has ensured the successful outcome of this so vital document. One can only say well done and congratulate all the partners in the IUCN family for its successful outcome.

\author{
G.LI. Lucas \\ Chairman of the IUCN Species Survival Commission
}

\section{Note on Authors}

Jane Thornback has been compiler of Mammal Red Data Books for some 13 years and is Head of the IUCN Species Conservation Monitoring Unit based at Cambridge, UK.

Phyllis Lee is an affiliated lecturer in Biological Anthropology at the University of Cambridge, she has worked on African primates for many years.

Elizabeth Bennett has worked extensively on primate conservation issues. She is currently working on a Proboscis Monkey and Mangrove Conservation Project in Sarawak. 


\section{ACKNOWLEDGEMENTS}

IUCN and the compilers are very grateful to the many individuals who provided essential information about the African primate species and their conservation status. Without their time, energy and generous response to seemingly endless requests for further clarifications, the inaccuracies would have been even more apparent! Special thanks are due to all the members of the IUCN/SSC Primate Specialist Group and to the members of the Conservation Working Group of the Primate Society of Great Britain.

Many people commented on the draft data sheets, sent reports from field sites, allowed access to unpublished data, and provided information on national conservation strategies and policies. We thank all those who contributed to this book and especially the following: P. Agland, C. Aveling, N. \& A. Badrian, R. Barnes, T. Butynski, P. \& S. Curtin, G. Davies, R. Dunbar, G. Drucker, J. Fa, M. Fernandez, S. Gartlan, J.-P. Gautier, J. Goodall, C. Groves, P. Grubb, C. Harcourt, A. Harcourt, M. Harrison, A. Kortlandt, H. Kummer, W. McGrew, C. Marsh, A. Mertz, J. Moore, J. Mshelbwala, F. Mturi, A. Peal, A. Rodgers, J. Sabater Pi, F. Silkilwasha, D. Starin, K. Stewart, C. Spinage, T. Struhsaker, R. Susman, G. Teleki, C. Tutin, A. Vedder, J. Verschuren and G. Whitesides

Special thanks are owed to Dr John Oates who generously provided much data for the drafting of the sheets, and took his valuable time to comment on the final versions in addition to writing an introductory section. His help has been invaluable in the production of the book.

Dr Russell Mittermeier (W.W.F.-U.S.) also assisted by commenting on drafts, providing photographs, and securing the essential financial assistance. We thank him for his committment to the project.

Without the patient work of IUCN/CMC staff, Rosina Abudulai and Julie Gray in typing the drafts and tolerating last minute changes, the book would not have been finished. Jo Taylor painstakingly translated the computer disks into print for the typesetters. We are very grateful for all the help.

Phyllis C. Lee

Jane Thornback

Elizabeth L. Bennett 


\section{CONTENTS}

INTRODUCTION

iii

The Red Data Books

The African Primates: Issues in conservation

Primate conservation and biomedical research

Applications of the African Primate Red Data Book

iii

iii

iv

$\mathrm{v}$

IUCN/SSC ACTION PLAN FOR AFRICAN PRIMATE CONSERVATION:

A SYNOPSIS

vii

Table of projects for priority action $\quad$ xi

THE IUCN/SSC PRIMATE SPECIALIST GROUP Xiii

DATA SHEETS $\quad \mathrm{xV}$

The organization of the data sheets $\quad x v$

Legislation covering African Primates $\quad$ xv

Request for further information $\quad x v$

The taxonomic classification followed xvi

CATEGORIES OF THREAT X XVii

THE AFRICAN PRIMATES AND THEIR DEGREE OF THREAT ～xix

DATA SHEETS OF THREATENED AFRICAN PRIMATES 1-145

$\begin{array}{ll}\text { APPENDICES } & 147\end{array}$

$\begin{array}{ll}\text { A. Inventory report form } & 147\end{array}$

B. Endangered primates covered by international conservation 149

C. WHO policy statement on the use of threatened primates in biomedical research

INDEX 
The IUCN Red Data Book

\section{INTRODUCTION}

\section{The Red Data Books}

The Red Data Books are designed to provide an inventory of threatened species and to focus attention on the earth's vanishing wildlife. The concept originated with Sir Peter Scott in the mid-1960s, and has expanded both as new information has become available and, unfortunately, as the number of species adversely affected by human activities grows. The purpose of the data sheets is to focus attention on species or groups of plants and animals that currently appear to be at risk of declining or disappearing as a result of contact with humans, and to encourage appropriate conservation action.

The regional emphasis of this volume is a further response to the increased amount of information available on threatened species. Focusing on a single geographic region allows for the more rapid publication and dissemination of data essential for developing conservation priorities. It also takes cognizance of the fact that conservation needs, problems and solutions often differ between regions. Conservation priorities are better addressed at a regional level and national priorities need to be determined within this context. It is for this reason that the IUCN/SSC Primate Specialist Group has drawn up Regional Action Plans for the conservation of primates. A discussion of the African Plan is presented in Section 4. An Asian Plan has recently been published. This volume is seen as complementary to the African Primate Action Plan and it is hoped that both will be regularly revised.

\section{The African Primates: Issues in conservation}

The African continent is probably the source of the higher primates in evolutionary terms, and is the home of a large proportion of extant species. Thus the survival and extinction of the African primates is of particular conservation concern. Primates are large-bodied species, in comparison to insects or birds, and environmental changes can have a great impact on the potential survival of a long-lived, large-bodied and slowly reproducing animal. Most primates tend to live in or near the area of their birth and thus cannot migrate to escape the effects of deleterious habitat changes. Behaviourally they are complex, living in structured social groups, often recognizing kin over several generations, forming long-lasting relationships with other individuals, and many require the exchange of individuals between groups before reproducing. The survival of primate taxa is thus markedly affected by individual reproductive potential, which in turn is influenced by an individual's ability to maintain long-term relationships within the context of its social group as well as that of the surrounding groups. Environmental changes habitat destruction or hunting pressures - all decrease the reproductive potential of primates, and can lead to rapid local extinctions. Small, genetically and socially isolated populations tend to result from the fragmentation of habitats. Such populations show increased vulnerability to the problems of disease, inbreeding and human pressures, potentially resulting in rapid local extinctions.

Primates thus can be indicators of the severity of the changes in a habitat. It is interesting that among the African primates, high levels of local genetic diversity and endemism have resulted from changes on the geological, rather than the human, time scale, and reflect the adaptations of primates to local ecological changes. Monitoring of the populations of primate species may allow us to assess the longer-term impact of human resource exploitation on the habitat as a whole.

Primates are a major component of the tropical ecosystems within which they live, and in some areas make up a large proportion of the mammalian biomass. They can affect leaf production on tree species and serve as dispersal agents for many species of seeds. They are both predators of other small mammals (and some birds), and prey for large carnivores such as leopards, many species of raptors and snakes. Unfortunately, they are also prey for the human species, and this has led to declines in their numbers. 
Most African primates do not exist as isolated taxa within an area of habitat but are intimately inter-related to the community as a whole. Many primate species associate with other primates while foraging and travelling; such associations can serve to minimize the effects of predation or increase information exchange about the locations of foods. Indeed, in some forests such as those in Sierra Leone, in the Côte d'Ivoire, the Nyungwe Forest in Rwanda and Kibale Forest in Uganda, as many as nine primate species co-exist, interact, and live at high densities. The mammalian diversity of these forests is accounted for primarily by the primates. With the maintenance of biological diversity being of the highest conservation concern, then an understanding of the role of primates within their community is an essential conservation priority. The community dynamics of African forest ecosystems are in the process of being examined, and are still poorly understood. Primates play a major role in structuring the community in some forested habitats, through interactions with trees and other food plants, in their role as predators, and as prey. Their removal through extinctions will increase the vulnerability of the entire system. Primates thus cannot be viewed as isolated components of a community; their presence or absence has implications for the continuance of a variety of plant, invertebrate and vertebrate species.

\section{Primate conservation and biomedical research}

The morphological, physiological and genetical similarities between humans and primate species has led to their extensive use in research seeking to improve the health and welfare of human populations. Understanding of disease transmission and control, of reproductive biology, of the workings of the brain, and of parasite-host relationships would not be possible without the use of primates kept in controlled laboratory conditions. The cost and benefits of such biomedical and behavioural research can be endlessly debated from the perspective of either the humans who benefit or the primates who suffer as a result of experimentation. These ethical considerations must also include the issue of the source of the primates for biomedical research. The live capture and international trade in primates for research is a major factor in the declines of some populations. In India, the Rhesus Macaque (Macaca mulatta) was under severe pressure from the trade with the export of as many as 200000 animals per year. The trade was banned in 1978. In western Africa, the export of Chimpanzees (Pan troglodytes) has probably led to drastic reductions in numbers. While this trade is currently relatively controlled, the demand for primate and particularly ape models for the study of disease could increase at any time and rapidly cause local or complete extinctions.

The conservation problem is the unpredictability of the demand for live-capture of primates. Global health issues such as major epidemics of communicable disease cannot be ignored by conservationists, but rather than open the flood gates to export, the burden of supplying the necessary numbers of primates for research must fall on the existing stocks of captive primates in breeding colonies. Some live capture may indeed be necessary for the maintenance of genetic diversity within long-term breeding facilities: such levels of capture are unlikely to pose a threat and can be carefully monitored. Wild populations cannot sustain the levels of offtake previously experienced in the face of threats from loss of habitat and hunting within source countries. The role of self-sustaining captive colonies in providing primates for essential biomedical research is now recognized as an urgent conservation priority.

The importance of minimizing trade in primates for biomedical research is emphasized by the World Health Organization (UN) policy statement on the use of threatened primate species for biomedical purposes (see Appendix C). Where possible, the emphasis should be in vitro rather than in vivo research, "Endangered" primates should not be used in projects and those primates that are used should come from captive bred populations. Such policies should apply equally to primates exported or used in institutions established in source countries.

The use of primate models remains critical to enhancing the welfare of humans. It must not, however, be accomplished at the expense of future generations of humans through the loss of their global resources - the extinction of primates in the wild. 


\section{Applications of the African Primate Red Data Book}

The primary aim in the production of this book is to identify species that are at risk, to pinpoint the sources of that risk where possible and to highlight areas within the continent where conservation efforts are either necessary or could potentially have a major effect on the survival of species. The evolutionary history of the primates in Africa has produced a taxonomist's nightmare (see below), and there are many more rare forms - subspecies, races, or local variants - than are dealt with in the following data sheets. The focus of this book is at the species, or occasionally, at the subspecies level. Furthermore, the approach is regional rather than national. In some cases, locally threatened species have been omitted: for example the deBrazza's Monkey (Cerco pithecus neglectus) appears to be relatively common in central Africa, while on the verge of extinction in Kenya. Priorities for the conservation of primate species or for the maintenance of primate diversity may differ from nation to nation; the development of these priorities is of major concern to conservationists and should be assisted in all possible ways. While the information presented here should aid in the development of such national conservation strategies, it is not specific to any nation. However, the ommission of a species that is rare or even endangered in one country while common in others should not be grounds for refusing to view that species as of valid and urgent conservation concern within a country's development strategy. The aim here is to cover as large an area as possible, and thus provide the background for regional strategies. Indeed, one of the main uses of the data sheets has been to assist in the development of the IUCN/SSC Primate Specialist Group's Action Plan for African Primate Conservation: 1986-90, written by Dr J.F. Oates (see below). The data sheets provided basic information for drafting the recommended conservation actions and for defining areas and habitats of specific conservation concern. Funding for primate conservation projects can thus be targeted to areas of high priority on a regional basis.

The identification of species at risk, and the causes of that risk can help provide the basic information needed to integrate local development needs and national development priorities with conservation priorities. We also hope that the information presented here can be used in projects designed to promote conservation education, for without the support of people living in close proximity to primates, the non-human primates are unlikely to survive. The importance of initiating programmes for conservation education can be seen in the changes in attitudes to pest species of primates (crop-raiders, urban pests), where simple removal of the pest can be avoided if the human influences causing the conflict can be understood by those involved. Education directed towards habitat management, combined with targeted species of primates, has been shown to decrease local conflict with conservation priorities as in the case of the Mountain Gorillas in Rwanda.

The IUCN/WWF/UNEP World Conservation Strategy has emphasized the need for environmental education as one method for influencing perceptions of environmental problems. Local conservation education programmes offer the potential for directing public attention to a specific problem and the role of the local population in finding solutions to these problems. With respect to the primates of Africa, education programmes to reduce the impact of hunting and to promote the development of natural resources within a framework of conservation priorities are urgently needed. 


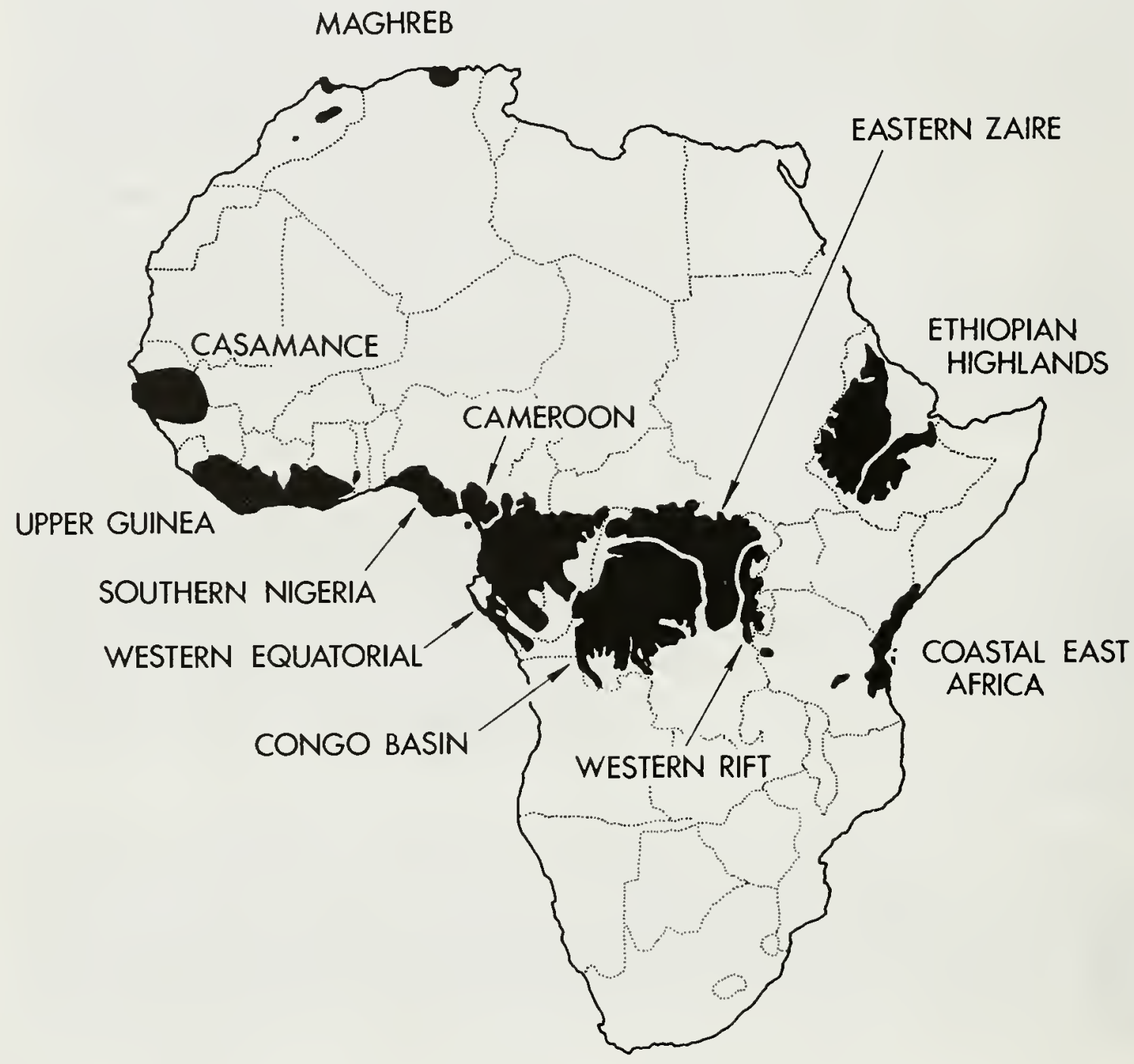

Except for desert areas, much of the rest of Africa carries savannah vegetation with a relatively uniform community of primates that is not currently under great threat. With the exception of the Casamance and Maghreb, regions are mapped here on the basis of vegetation distributions shown by White (1983) (map: Stephen Nash). 
The IUCN Red Data Book

THE IUCN/SSC ACTION PLAN FOR AFRICAN PRIMATE CONSERVATION: A SYNOPSIS

\author{
by \\ John F. Oates \\ Hunter College, New York
}

The Red Data Books serve very important functions in identifying threats to the survival of individual species and subspecies, and in summarizing conservation measures needed or underway, to ameliorate these threats. In a conservationist's ideal world, all those measures would be acted upon immediately. In reality, resources of money and suitably trained personnel for conservation are scarce, and limit the range of actions that can be taken at any particular time. This is especially true in the generally impoverished nations of tropical Africa. Thus it is necessary to plan carefully the use of such resources as are available. As far as possible, resources should be directed where they are most urgently required and allocated in such a way that a maximum number of conservation goals are achieved by any one project. There is also a need for objective scientifically-based overview of patterns of biological diversity across large regions (and of threats to the survival of that diversity). Such overviews can help to identify localized conservation needs that might be neglected in conservation plans generated largely from information on a set of existing projects. For instance, because biologists and conservationists have until now paid rather little attention to one particular area (such as the Republic of Congo), this does not necessarily mean that this area is insignificant in terms of its wildlife resources, or that conservation activities there would not yield valuable results.

This thinking lay behind the Action Plan for African Primate Conservation: 1986-90, published by the IUCN/SSC Primate Specialist Group (PSG) in 1986. The plan grew out of the Global Strategy for Primate Conservation, prepared by PSG Chairman Russell A. Mittermeier in 1978, and from a planning paper written by J. Stephen Gartlan, Thomas T. Struhsaker and myself in 1981 (a published version of this paper, "A Framework for African Rain Forest Primate Conservation," may be found in Primate Conservation in the Troipical Rain Forest, edited by C.W. Marsh and R.A. Mittermeier, 1987). The chief aim of the Action Plan is to provide those responsible for planning conservation strategies and allocating funds with a relatively unbiased guide to projects that could protect the existing diversity of the African primate fauna in a representative set of ecosystems (especially those containing a high species diversity and/or abundant populations). The plan also attempts to assess the relative priority of these projects. It focuses on the maintenance or establishment of protected areas as keystones for continent-wide conservation efforts. Of course, broader conservation efforts, such as national conservation strategies, education and awareness programmes, the management of non-reserved areas, and the revision or better implementation of laws covering hunting, trapping and trade are all essential for the effective long-term conservation of primates and other wildlife populations. In drawing up the Action Plan, the PSG was aware of these broader needs, but also felt that there was an urgent need to identify special natural areas for protection-oriented management before these areas are destroyed or radically modified. Because relatively large areas are required for the effective conservation of primate populations, the actions proposed in the plan for primate conservation would also safeguard a large variety of other animal and plant species and the systems on which they depend.

The primary sources of information used in identifying projects for special conservation attention were the members of the African Section of the PSG and the database of the IUCN Conservation Monitoring Centre. The first step taken in organizing this information into a planning framework was to draw up a species-level classification of African primates, a classification laying particular emphasis on differences between populations. Any population or set of populations that had been considered by respected authorities to belong to a distinct species or genus is in general given that status in the plan. The PSG wished to avoid neglecting any population "lumped" with others by some taxonomists, only to find it recognized as unique when it is too late to save it from extinction. The plan also takes note of a number of especially marked subspecies. With a few exceptions, this Red Data Book follows the same classification as the Action Plan. 
Having established a classification, the Action Plan proceeds to rank the African primate species in terms of their priority for conservation attention. A numerical score is given to each species based on:

(1) the degree of threat to the survival of its populations (scored on a scale from 1, for no known present threat, to 5, signifying a highly endangered species);

(2) the taxonomic uniqueness of the species (scored from 1, for a member of a group of closely-related species, to 3 , for members of a genus with only one or two species); and

(3) geographical association with other threatened forms (scored as 1 , for a species having little overlap with other threatened forms or a wide geographic range, or 2 , for a species with much of its range overlapping with one or more threatened forms).

On this basis, the six species receiving the highest rating (a total score of 9) for conservation action are the Gorilla (Gorilla gorilla), the Pygmy Chimpanzee (Pan paniscus), Gordon's or Uhehe Red Colobus monkey (Procolobus [badius] gordonorum), the Drill (Mandrillus leucophaeus), Preuss's Guenon (Cercopithecus preussi) and Sclater's Guenon (sometime regarded as a distinct species Cercopithecus sclateri, and in this book as a subspecies of C. erythrotis).

Next, the plan identifies geographical areas worthy of special attention from the viewpoint of primate conservation. The Action Plan recognizes that primates, like other animal and plant species, do not occur in random distributions but belong to distinct regional communities. Effective conservation of each regional community is necessary if patterns of continent-wide diversity are to be maintained. In general, the primates of African savanna-zone commmunities do not at this time require special conservation attention. Most of the savanna primates have wide geographical distributions, reasonable population sizes and occur in several national parks or other protected areas. These species tend to be ecologically flexible which makes them less susceptible to environmental change. However, in agricultural areas they are often regarded as pests, which could pose a threat for the future. Currently, the Action Plan focuses on forest primates, which tend to be ecological specialists, to occur at low population densities, and to be threatened in varying degrees by habitat destruction and hunting (monkeys and apes are an important sources of animal protein for many human communities in the African rain forest zone).

A review of existing patterns of distribution and diversity suggests that the most threatened African primates are located in 11 regional communities (see map). Seven of these are areas of lowland and/or montane rain forest which show high levels of endemism at the species and subspecies level among primates and other wildlife (the areas are Upper Guinea, southern Nigeria, Cameroon, Western Equatorial Africa, the Congo Basin, Eastern Zaire, and the western Rift Valley). The four other special areas are the Casamance and Fouta Djalon woodlands of West Africa, the Maghreb of North Africa, the Ethiopian Highlands, and the dry forests in coastal regions of East Africa. Effective conservation action at sites in each of these regionscould protect a major part of the present diversity of African primates (assuming the continued health of populations in other, savannah, areas). More than one site needs attention in each region, in part because there can be no guarantee for the long term security of any one site, and in part because of diversity within regions. For instance, the Upper Guinea forests support two sets of primate diversity in the form of subspecies, one distributed between Sierra Leone and western Côte d'Ivoire, and the other between western Côte d'Ivoire and Ghana. The forests of the western Rift Valley and of coastal East Africa are highly fragmented and different fragments support different sets of primate species and subspecies.

Forty-two different project areas are identified in the Action Plan as requiring priority attention in the 1986-90 period if the present diversity of African primates and primate habitats is to be maintained into the next century. Between them, these areas support all the Endangered and Vulnerable forms listed in the Red Data Book. Twenty-four of the areas contain sites that are either already protected sites, or have been identified as worthy of protection. In these cases, the Action Plan outlines management projects needed to provide more effective primate 
conservation. In 18 other areas, survey projects are proposed to investigate the status of primate populations and to make recommendations for their protection. The relative priority of the 42 projects is established in the Action Plan by a similar ranking system to that used for individual species. Each project area is scored on four parameters:

(1) the total number of threatened primate species present (scored on a scale from 1, for one or two high priority species, to 4 for seven to eight species;

(2) the imminence of threat to the area's ecosystem (scored from 1 for low present threat, to 4 for a very high degree of threat);

(3) the overall primate species diversity in the area (scored from 1, for five or fewer species, to 3 for ten or more species); and

(4) the number of endemic species or subspecies in the area (scored from 1, for one or two subspecies, to 3 for two or more endemic species).

Based on this scoring system, the two highest-scoring projects (with 13 points each) are surveys of the area between Mamfe in Cameroon and Obudu in Nigeria (home to an isolated population of Western Gorillas), and of Bioko Island (Fernando Po) in Equatorial Guinea. In addition to estimating their relative priority for conservation action, the Action Plan also provides an estimate of the cost of each project in the $1986-90$ period. These estimates are provided as a guide only, both to planners such as representatives of national governments, officers of international organizations, and to individuals seeking to become involved in worthwhile projects. They are rough estimates only, often very rough estimates. Project priorities and estimated costs are listed in Table 1. The total estimated cost, $\$ 2290000$, is relatively modest by the standards of most international development plans.

To what extent has the Action Plan been implemented since its publication in 1986? At the outset, it was hoped that one or more large conservation organizations would adopt the Action Plan and endeavour to implement it in whole or in part. While no organization has attempted to realize the plan in total, many parts of it nonetheless are being implemented. Since the initial circulation of a draft of the plan in 1985, primatologists and wildlife biologists (both students and professionals) have been stimulated to undertake projects listed in the plan. In other cases, the listing has been used to support applications for funds on the part of existing or proposed projects. At the same time, a number of organizations (notably WWF and Wildlife Conservation International) have paid special attention to the plan when deciding whether to support proposals submitted to them. Thus, many projects recommended by the plan have been completed, are in progress, or are being planned, albeit in a somewhat less systematic fashion than was originally envisaged. An example of this is the survey of primates on Bioko Island carried out by Thomas M. Butynski (a PSG member) and Stanley H. Koster in January-March 1986. This survey, stimulated in significant part by the Action Plan, was funded by the WWF and Chicago Zoological Society.

There had never been a careful survey of Bioko primates, most of which are endemic species or subspecies. However, concern for their survival was expressed as long ago as 1969, when it was reported that "unrelenting persecution by local hunters threatens five of the island's monkeys" (Oryx, 10:146-147). Butynski \& Koster found that Bioko primates were less seriously threatened than had been feared. Two decades of political and economic difficulties on Bioko had actually led to a decline in hunting pressure and a regrowth of some forest areas, so that the status of primate populations had improved. As a result of their survey, Butynski \& Koster recommended several actions to secure the future of Bioko's unique fauna of primates and other animals. These recommendations included the establishment of a conservation education programme and a research station (T.M. Butynski \& S.H. Koster, paper presented at XIth Congress of the International Primatological Society, Göettingen, 1986).

Preliminary surveys have also been conducted within the other very high priority area identified by the Action Plan, the forested area straddling the Cameroon-Nigeria border between Mamfe and Obudu. This is an area of especially high faunal and floral endemism containing an overlooked population of Western Gorillas (Gorilla gorilla gorilla), whose survival 
had been in doubt. Several other primates thought to be "Endangered" or "Vulnerable" (including the Drill, Mandrillus leuco phaeus) were also believed to occur here. Two surveys of the area were recently completed by PSG members. In May 1987, in Cameroon, J. Michael Fay trekked from Mamfe to Mbilishe and then on into the Takamanda Forest Reserve adjacent to the Nigerian border. He saw Gorillas, Preuss's Guenons (Cercopithecus preussi), Red-eared Guenons ( $C$. erythrotis), Mona and Putty-nose Guenons ( $C$. mona and $C$. nictitans), Red-capped Mangabeys (Cercocebus torquatus), and the nests of Chimpanzees (J.M. Fay, personal communication). Fay is planning a follow up to this WWF funded project. With support from the Nigerian Conservation Foundation, A.H. Harcourt and K.J. Stewart visited the Nigerian part of this forest area in December 1987 and January 1988. Gorillas, Chimpanzees and Drills were all found to be present, and plans for their better conservation are being formulated (A.H. Harcourt, personal communication).

Over half the projects listed in the Action Plan are (in mid 1988) in progress or completed. These include a study of the effects of logging on ape populations in the Lope Reserve of Gabon by Caroline Tutin and others, and conservation-oriented research programmes on the Tana River of Kenya (Barbara Decker), in the Nyungwe Forest of Rwanda (Amy Vedder), and in the Impenetrable (Bwindi) Forest of Uganda (Thomas Butynski). Significant gaps still exist, however, in the implementation of the plan. The Upper Guinea forests of West Africa remain relatively neglected, and the status of forests and primates in the Republic of Congo and in much of the Congo Basin of Zaire are still very poorly known. This Red Data Book should stimulate interest both in the completion of the unfulfilled elements of the Action Plan, and in the production of a subsequent plan. Such a plan will need to take account of new knowledge of African primate populations, which this publication reflects. In addition, the Plan's scope could sensibly be broadened beyond surveys and the management of protected areas to encompass projects aimed at spreading awareness of conservation issues, training personnel, studying interactions between human and nonhuman primate populations, promoting the survival of primate populations outside reserved areas, and breeding threatened primates in captivity for possible subsequent reintroduction to the wild. 
TABLE 1. Projects identified for priority action in the IUCN/SSC Action Plan for African Primate Conservation: 1986-90.

\section{PROJECT}

Survey of Mamfe-Obudu area

Survey of Bioko

Regional survey: eastern and central areas

Survey of Oban Hills

Nationwide survey

Survey of Lofa-Mano region

Survey of Wamba region

Management of Tai Forest

Survey of proposed Dja

National Park

Development of Lomako reserve

Conservation of Bwindi Forest

Research on Tana River

Survey of Ituri Forest

Survey of Maiko region

Survey of Ogun and Ondo

Survey of Niger-Cross region

Development of Sapo Park

Conservation of Gola Forest

Conservation of Nini-Souhien and Bia Parks

Development of Korup Park

Conservation of Lopé Reserve

Reserve development, north-eastern region

Reserve development, southern region

Conservation of Okomu Forest

Conservation of Kibale Forest

Survey of Salonga Park

Survey, Lukenie-Sankuru region

Survey, north-east region

Nationwide survey

Survey of V:'. Rift forests

Conservation of Kahuzi-Biega Park

Conservation of Uzungwa Mts

Survey of coastal forests

Conservation of Nyungwe Forest

Survey of Harrar area

Barbary macaque conservation

Protection of Virunga Volcanoes

Conservation of Simen Mountains

Study of Bale Mountains

Protection of Zanzibar forests

Chimpanzee research at Gombe

Development of Mahale Park

\section{COUNTRY}

on, Nigeria

Equatorial Guinea

Côte d'Ivoire

Nigeria

Congo Republic

Liberia

Zaire

Côte d'Ivoire

Cameroon

Zaire

Uganda

Kenya

Zaire

Zaire

Nigeria

Nigeria

Liberia

Sierra Leone

Ghana

Cameroon

Gabon

Gabon

Central African

Republic

Nigeria

Uganda

Zaire

Zaire

Angola

Guinea

Zaire

Zaire

Tanzania

Kenya

Rwanda

Ethiopia

Morocco, Algeria

Tunisia

Zaire,Uganda,Rwanda

Ethiopia

Ethiopia

Tanzania

Tanzania

Tanzania

\section{PRIORITY ESTIMATED \\ RATING COST \\ (See text) (U.S.\$)}

13

30,000

20,000

25,000

25,000

50,000

25,000

50,000

100,000

50,000

50,000

100,000

65,000

50,000

30,000

20,000

20,000

160,000

150,000

40,000

150,000

120,000

30,000

25,000

60,000

100,000

40,000

25,000

25,000

60,000

50,000

20,000

40,000

15,000

100,000

25,000

60,000

100,000

50,000

25,000

20,000

60,000

30,000 



\section{THE IUCN/SSC PRIMATE SPECIALIST GROUP}

The IUCN/SSC Primate Specialist Group (PSG) has been in existence since the late $1960 \mathrm{~s}$ and has been under the leadership of its present Chairman, Dr Russell A. Mittermeier, since 1977. The group is one of numerous specialist groups of the Species Survival Commission of IUCN and its membership has grown to nearly 200 primate scientists and conservationists from 45 different countries. The PSG is organized into six main subdivisions, corresponding to the four regions where primates occur, together with a captive breeding division and a special division for miscellaneous activities (i.e. conservation education, satellite imagery analysis, veterinary medicine, wildlife trade).

The goal of the PSG is to maintain the current diversity of the order Primates, with dual emphasis placed on:

1. ensuring the survival of threatened species wherever they occur;

2. providing effective protection for large numbers of primates in areas of high primate diversity and/or abundance.

Activities underway in many parts of the world make it inevitable that a certain portion of the world's forests and the primates which reside in them will disappear. The role of the PSG is to minimize this loss wherever possible by:

1. setting aside special protected areas for threatened species;

2. creating large national parks and reserves in areas of high primate diversity and/or abundance;

3. maintaining parks and reserves that already exist and enforcing protective legislation in them;

4. creating public awareness of the need for primate conservation and the importance of primates as a natural heritage in the countries where they occur.

The PSG places particular emphasis on conservation of habitat and furtherance of conservation education as both these measures are considered essential and in large part inseparable. Regardless of how broadly one wishes to define conservation, long-term survival of natural populations will not be possible if habitats are not preserved and if local people in the areas where primates occur do not fully support conservation efforts. Additional measures taken by the PSG include:

5. determining ways in which man and his fellow primates can coexist in multiple use areas;

6. establishing conservation oriented captive breeding programs for "Endangered species";

7. ending all illegal and otherwise destructive traffic in primates;

8. ensuring that research institutions using primates are aware of the conservation problems and that they are using primates as prudently as possible, without threatening the survival of any wild populations.

Among the many functions of the PSG are production of the newsletter/journal Primate Conservation (formerly the IUCN/SSC Primate Specialist Group Newsletter), edited by Isabel Constable, which is a major means of communication among the world's primate conservationists and is distributed free of charge to PSG members. The PSG is also responsible for the production of Action Plans for Primate Conservation, which update the original Global Strategy for Primate Conservation, produced in 1977. These Action Plans are intended to determine priorities in global primate conservation, to estimate the costs of conserving the world's primate fauna and to serve as tools in the fundraising efforts to make these projects possible. The first two regional Action Plans, the Action Plan for African Primate Conservation 1986-1990 by John Oates (as already mantioned), and the Action Plan for Asian Primate 


\section{Threatened Primates of Africa}

conservation 1987-1991 by Ardith Eudey, have already been published and others for the Neotropical region and Madagascar are in preparation.

For further information on the IUCN/SSC Primate Specialist Group, please contact:

Russell A. Mittermeier

World Wildlife Fund Primate Program

Dept. of Anatomical Sciences, HSC

State University of New York

Stony Brook, NY 11794-8081

USA 


\section{DATA SHEETS}

\section{The organization of the data sheets}

The data sheets usually describe a single species. Each listing gives the common English name (where known), the scientific name, the assessment of its IUCN category (see below) and a brief summary of the information available on the species' distribution, population sizes, habitats and ecology, threats, and conservation measures. Each of these topics is then covered in detail, and followed by a statement of captive breeding, and remarks on description of the species, taxonomy and acknowledgements. References to published information and correspondence with consulting experts complete each sheet (see Appendix A). In cases where a subspecies is known to be "Endangered" while the species as a whole is less at risk, information is given separately for that subspecies. In some cases, the data sheets present information for a species on a country by country basis, since the laws pertaining to wildlife and the problems faced by a species may be specific to a particular nation. This is especially true when a species is found in many different countries - such as the Chimpanzee (Pan troglodytes) which occurs in 25 nations.

\section{Legislation covering African Primates}

Many of the species considered in this book are covered by national wildlife, conservation, or hunting regulations. Wherever possible, the relevant legislation has been presented. The IUCN Environmental Law Centre: Wildlife Laws has been consulted for appropriate national laws and regulations. A further source of information is the IUCN/WWF (Traffic (U.S.A.) publication The International Primate Trade, Vol. 1. (1984), edited by D. Mack and R.A. Mittermeier.

Two international agreements restrict the killing, capture and trade in African primate species. The first is that of the African Convention (1969), signed by 28 nations and signed but not ratified by a further 14 . This agreement undertakes the signatories to adopt measures necessary to ensure conservation, utilization and development, and to accord special protection to those animal and plant species that are threatened with extinction, or which may become so, and to the habitats necessary for their survival. Protected species are designated in Class $A$ of the Convention, and may be hunted, killed, captured or collected only on the authorization of the highest competent authority, if required in the national interest or for scientific purposes. All other primates, except the common Baboon (Pa pio species) are considered under Class $B$ of the Convention, and may be hunted, killed, captured or collected only under special authorization granted by the competent authority.

The second international agreement is that of the 1973 Convention on International Trade in Endangered Species of Wild Fauna and Flora (CITES). Species are listed in two appendices. Appendix 1 lists species threatened with extinction. Trade in the species or their products listed on Appendix 1 is subject to strict regulation by ratifying nations, and trade for primarily commercial purposes is banned. Appendix 2 lists species that could become endangered if trade is not controlled. Trade between ratifying nations in species or their products listed on Appendix 2 is subject to regulation and monitoring of its effects. Species that are difficult to distinguish from listed species are also included on Appendix 2, to prevent illegal trade through misidentification.

The protection given to each species under the two agreements is listed on the separate data sheets. In Appendix B, those species protected from trade, and from hunting or capture are presented, along with a number of "Endangered" species whose status should be reconsidered.

\section{Request for further information}

The data sheets are continually reviewed and updated. No statement is definitive - except, possibly, for that of extinction. While the data sheets are as accurate as possible, they do rely on information that must be provided by those in the field, and conditions are seldom constant 
between intervals of publication. Thus, there will be omissions and errors, and probably annoyance over differences of opinion. It is hoped that these will stimulate people to provide the missing information, and update records at the address and in the format of the sample Inventory Report Form given in Appendix A.

\section{The taxonomic classification followed}

The system of classification used here primarily follows that of Oates (1986) in the Action Plan for African Primate Conservation. In dealing with conservation issues, it is often of more use to recognize the differences between groups of similar animals, especially when there are major regional distinctions. As such, a classification that retains the maximum level of diversity may have more applications to conservation problems.

This raises the problem of subspecies: should a subspecies be considered as an appropriate category for conservation? Should conservation priorities be based on the minor variation within a group of similar primates, or on the major divisions of region, habitat, behaviour and genetics? Among the African primates, the advance and retreat of the tropical forests throughout the last two million years has led to high levels of endemism among primates, especially the cercopithecines and colobines. However, for many groups their evolution in the face of such habitat fragmentation and rejoining has been relatively recent and may be less reflected in genetic differences than in morphological variability. Thus, the conservation status of those subspecies with marked regional, behavioural or morphological differences has been taken into account below.

The classification followed here has the following characteristics:

1) In keeping with Oates, the Galago demidovii group is separated into Galago demidovii and $G$. thomasi. The taxonomy of the Galagos is under revision, but the differences in body size, locomotor patterns, vocalizations, pelage, and distribution suggest that $G$. thomasi is a valid taxon.

2. Taxonomy of the Papio group is also confused; some authors consider all common or "savannah" Baboons to be subspecies of $P$. cynoce phalus since they readily interbreed in the wild. Furthermore, Mandrills and Drills are often placed in the genus Papio rather than separately in Mandrillus. We have followed the conservative classificatioin in this respect, and kept the different types of Papio as separate species, and have retained the designation of Mandrillus.

3) We have accepted the designation of Cercopithecus preussi and C. albogularis as full species, and have included the recently (1988) named $C$. solatus, which was referred to as "Harrison's monkey" by Oates. We have, however, excluded C. sclateri as a full species, since there is little recent information available on the taxonomic affinities of this animal. It is considered as a subspecies of $C$. erythrotis, an extremely endangered species.

4) Unlike Oates, we have not separated the Miopithecus into the northern and. southern species, as there is insufficient evidence at present for either its taxonomic status or conservation concern. It should however be monitored closely.

5) We have followed Oates' classification of the Colobus monkeys - another extraordinarily confused group. The genus Colobus is reserved for the species of Black-and-white monkeys, while the Olive and Red Colobus are grouped together as Procolobus. The Red Colobus Procolobus badius present yet another taxonomic nightmare: there are at least 14 subspecies, or possible species. We have used Oates' separation of the badius group into five separate forms - the Eastern Red rufomitratus species group, the Western Red or badius group, the Pennant's Red or pennanti group, the Uhehe or gordonorum form, and the Zanzibar or kirkii form (the latter two may be full species). All are designated as part of the superspecies [badius]. The subspecies included in each group also follow Oates. 


\section{CATEGORIES OF THREAT}

The species identified as threatened by IUCN are assigned a category indicating the degree of threat as follows:

\section{ENDANGERED (E)}

Taxa in danger of extinction and whose survival is unlikely if the causal factors continue to operate.

This category includes taxa whose numbers have been reduced to a critical level or whose habitats have been so drastically reduced that they are deemed to be in immediate danger of extinction.

\section{VULNERABLE (V)}

Taxa believed likely to move into the "Endangered" category in the near future should the causal factors continue to operate.

This category includes taxa whose populations are decreasing because of over-exploitation, extensive habitat destruction or other environmental disturbance; taxa with populations that have been seriously reduced and whose ultimate security has not yet been assured; and taxa with populations that are still abundant but are under threat from severe adverse factors throughout their range.

\section{RARE (R)}

Taxa with small world populations that are not at present "Endangered" or "Vulnerable", but are at risk.

These taxa tend to be localized within restricted geographical areas or habitats, or are thinly dispersed over a more extensive range.

\section{INDETERMINATE (I)}

Taxa known to be "Endangered", "Vulnerable", or "Rare" but where there is not enough information to say which of the three categories is appropriate.

\section{INSUFFICIENTLY KNOWN (K)}

Taxa that are suspected but not definitely known to belong to any of the above categories, because of lack of information.

\section{NOT THREATENED (nt)}

Taxa that are not considered to be threatened at the present time. 


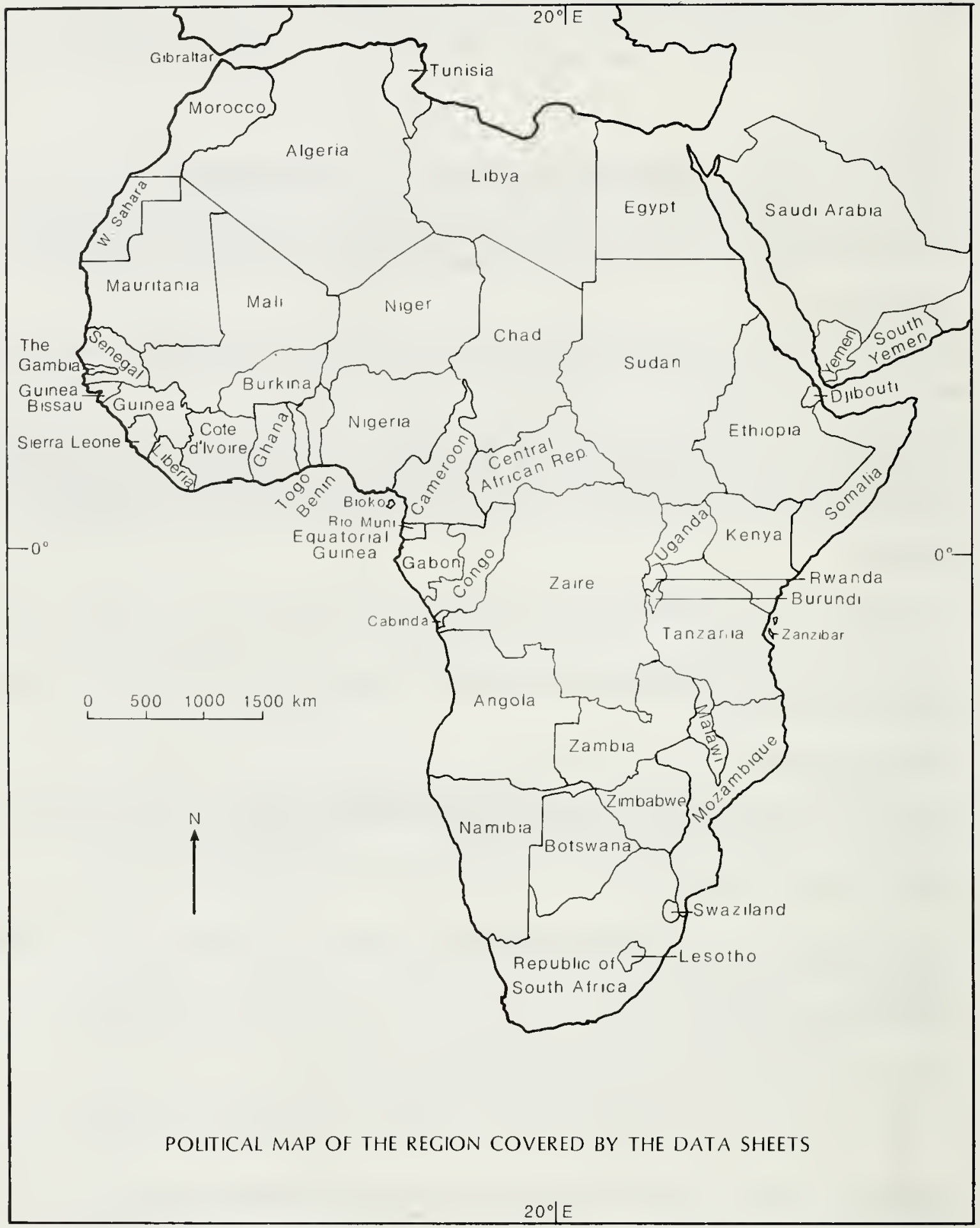


TABLE 2: THE AFRICAN PRIMATES AND THEIR DEGREE OF THREAT

Family LORISIDAE

Subfamily Lorisinae Arctocebus calabarensis Perodicticus potto

Subfamily Galaginae

Galago alleni

Galago demidovii

Galago thomasi

Galago inustus

Galago senegalensis

Galago zanzibaricus

Galago elegantulus

Galago crassicaudatus

Galago garnettii

\section{Family CERCOPITHECIDAE}

Subfamily Cercopithecinae

Macaca sylvanus

Cercocebus atys

Cercocebus torquatus

Cercocebus galeritus

C. g. galeritus

C. galeritus

subspecies "sanjei"

Cercocebus albigenia

Cercocebus aterrimus

Papio papio

Papio cynoce phalus

Papio ursinus

Papio hamadryas

Thero pithecus gelada

Mandrillus sphinx

Mandrillus leuco phaeus

Cerco pithecus diana

Cerco pithecus salongo

Cerco pithecus neglectus

Cerco pithecus hamlyni

Cerco pithecus lhoesti

Cerco pithecus preussi

Cerco pithecus solatus

Cerco pithecus albogularis

Cerco pithecus mitis

Cerco pithecus nictitans

Cerco pithecus petaurista

Cerco pithecus erythrogaster

Cerco pithecus erythrotis

Cerco pithecus ce phus

Cerco pithecus ascanius

Cercopithecus mona

Cerco pithecus aethio ps

Mio pithecus tala poin

Alleno pithecus nigroviridis

Erythrocebus patas
Angwantibo $\mathrm{K}$

Potto nt

Allen's Galago nt

Dwarf Galago nt

Thomas's Galago K

Eastern Needle-clawed Galago nt

Bushbaby nt

Zanzibar Galago V

Western Needle-clawed Galago nt

Thick-tailed Galago nt

Garnett's Galago nt

Barbary Macaque V

Sooty Mangabey nt

Red-capped Mangabey V

Crested Mangabey nt

Tana River Mangabey E

Sanje Mangabey E

Grey-cheeked Mangabey nt

Black Mangabey K

Guinea Baboon nt

Yellow Baboon nt

Chacma Baboon nt

Hamadryas Baboon $\quad$ R

Gelada Baboon R

Mandrill V

Drill E

Diana Monkey V

Salongo Monkey V

DeBrazza's Monkey nt

Owl-faced Guenon V

L'Hoest's Guenon V

Preuss's Guenon E

Sun-tailed Guenon V

Sykes's Monkey nt

Blue Monkey nt

Putty-nosed Guenon nt

Spot-nosed Guenon nt

White-throated Guenon E

Red-eared Guenon E

Moustached Guenon nt

Red-tailed Guenon nt

Mona Monkey nt

Vervet, Green Monkey nt

Talapoin nt

Allen's Swamp Monkey K

Patas Monkey nt 
Subfamily Colobinae

[Superspecies badius] Procolobus badius

P.b. waldroni

P.b. temminckii

P.b. badius

Procolobus pennanti

P.p. bouvieri

P.p. pennanti

P.p. preussi

Procolobus rufomitratus

P.r. ellioti

P.r. foai

P.r. oustaleti

P.r. tholloni

P.r. te phrosceles

P.r. rufomitratus

Procolobus gordonorum

Procolobus kirkii

Procolobus verus

Colobus satanas

Colobus polykomos

Colobus guereza

Colobus vellerosus

Colobus angolensis

Family Pongidae

Pan troglodytes
P.t. verus
P.t. troglodytes
P.t. schweinfurthi
Pan paniscus
Gorilla gorilla
G.g. gorilla
G.g. berengei
G.g. graueri

Red Colobus V

Western Red Colobus V

Miss Waldron's Bay Colobus E

Temminck's Red Colobus R

Bay Colobus V

Pennant's Red Colobus E

Bouvier's Red Colobus E

Pennant's Red Colobus E

Preuss' Red Colobus

Eastern Red Colobus $\quad$ V

Elliot's Red Colobus K

Foa Red Colobus K

Oustalet's Red Colobus $\quad$ K

Thollon's Red Colobus K

Uganda Red Colobus V

Tana River Red Colobus E

Gordon's Red Colobus E

Zanzibar Red Colobus E

Olive Colobus $\quad \mathrm{R}$

Black Colobus E

Western Black-\&-white Colobus nt

Guereza nt

Geoffroy's Black-\&-white Colobus nt

Angola Black-\&-white Colobus nt

Chimpanzee V

Western Chimpanzee E

Central Chimpanzee V

Eastern Chimpanzee V

Pygmy Chimpanzee V

Gorilla V

Western Lowland Gorilla

Mountain Gorilla E

Eastern Lowland Gorilla E 
The IUCN Red Data Book

INSUFFICIENTLY KNOWN

\author{
Arctocebus calabarensis (Smith, 1860)
}

Order PRIMATES

Family LORISIDAE

SUMMARY Angwantibos occur in rain forest in western Equatorial Africa from Nigeria to Zaire. They are nocturnal, insectivorous and solitary. Habitat destruction is thought to pose a threat since they are localized and specialized in their habitat preferences. Comparatively little is known about the abundance or conservation status of the species and further studies are needed. They do not survive or breed well in captivity. Included in both the African Convention (Class B) and on CITES (Appendix 2).

DISTRIBUTION The species is widespread, but localized in coastal and lowland Equatorial rain forests between the Niger and Zaire Rivers. It occurs from south-eastern Nigeria, through Cameroon, Rio Muni (Equatorial Guinea), Gabon, and Congo (Brazzaville) to Zaire $(8,9,10)$. Even within a single forest area, its distribution is extremely patchy (4). Two subspecies are commonly recognized: $A$ c. aureus from Gabon, and $A$. c. calabarensis (7). For a map see (10).

POPULATION No overall population estimates exist. It is considered rare in Gabon, where densities of 2 per sq. $\mathrm{km}$ were found in dense primary forest and 7 per sq. $\mathrm{km}$ in thickets in secondary forest. It was absent from large areas of apparently suitable habitat $(3,4)$. In the late 1960s it was thought to be abundant but vulnerable in Nigeria (6), and was common in Rio Muni in the early 1970s (10). No information is available from Cameroon, Congo or Zaire. This species lives at one of the lowest densities reported for members of the Lorisidae (1).

HABITAT AND ECOLOGY Angwantibos are found primarily in tree-fall zones in primary and secondary forests, at farmland edges and in some forestry plantations $(1,2,3,4)$. Their preferred habitat is lianas and small branches in low, dense undergrowth $(2,4,6)$. Typically, they are found below $5 \mathrm{~m}$ and never above $15 \mathrm{~m}$ in primary forest $(2,3,6)$ and seldom venture across more than a few metres of open ground. A nocturnal, slow moving and cautious climber, feeding mainly on insects $(85 \%)$ which are located by scent $(2,3)$. The most common prey is caterpillars, but beetles and other insects are eaten, along with some fruit $(15 \%)(2,3)$. Most foraging is solitary, but two adults or a mother and infant are occasionally seen together (2). Dense patches of foliage are used as sleeping sites $(2,3)$. No data are yet available on home range sizes or associations between the sexes (1). Births are aseasonal, with a slight reduction in frequency in the dry season (3). Females give birth to single infants, and may breed twice a year $(1,3)$. Gestation length is between 131-136 days (1), and the infant clings to the mother or is parked while she forages (2).

THREATS Major threats are habitat destruction from forestry and clearance for cultivation, as well as some hunting for meat in Nigeria (6). Similar threats from habitat loss probably exist in other countries within its range. The Angwantibo's ability to inhabit secondary forests may improve its chances of survival, as long as dense undergrowth remains and inter-tree distances are not so great as to inhibit its ability to cross open ground.

CONSERVATION MEASURES The species is totally protected by law in Gabon, but is not known to be legally protected in the other countries within its range. Further studies are needed to assess its occurrence in protected areas, as well as its distribution and population sizes before adequate conservation measures can be recommended.

All members of the Family Lorisidae are included in Class B of the African Convention (1969); they may be hunted, killed, captured or collected only under special authorization granted by the competent authority.

It is listed on Appendix 2 of the 1973 Convention on International Trade in Endangered Species of Wild Fauna and Flora, trade in it between acceding nations being subject to regulation and monitoring of its effects. 
CAPTIVE BREEDING It does not breed well in captivity and appears not to be suited to captive conditions (7).

REMARKS For a description of the species see $(3,5,7)$.

IUCN is grateful to Caroline Harcourt who prepared the draft data sheet for this species.

\section{REFERENCES}

1. Bearder, S.K. (1987). Lorises, bushbabies and tarsiers: Diverse societies in solitary foragers. In: Smuts, B.B., Cheney, D.L., Seyfarth, R.M., Wrangham, R.W. and Struhsaker, T.T. (Eds), Primate Societies. University of Chicago Press, Chicago.

2. Charles-Dominique, P. (1974). Ecology and feeding behaviour of five sympatric lorisids in Gabon. In: Martin, R.D., Doyle, G.A. and Walker, A.C. (Eds), Prosimian Biology. Duckworth, London.

3. Charles-Dominique, P. (1977). Ecology and Behaviour of Nocturnal Primates. Duckworth, London.

4. Charles-Dominique, P. and Bearder, S.K. (1979). Field studies of loris behaviour: Methodological aspects. In: Doyle, G.A. and Martin, R.D. (Eds), The Study of Prosimian Behaviour. Academic Press, London.

5. Hill, W.C.O. (1953). Primates: Comparative Anatomy and Taxonomy, Vol. 1: Strepsirhini. Edinburgh University Press, Edinburgh.

6. Jewell, P.A. and Oates, J.F. (1969). Ecological observations on the lorisoid primates of African lowland forest. Zoologica A fricana 4:231-248.

7. Napier, J.R. and Napier, P.H. (1967). A Handbook of Living Primates. Academic Press, New York.

8. Petter, J. and Petter-Rousseaux, A. (1979). Classification of the prosimians. In Doyle, G.A. and Martin, R.D. (Eds), The Study of Prosimian Behaviour. Academic Press, London.

9. Oates, J.F. and Jewell, P.A. (1967). Westerly extent of the range of three African lorisoid primates. Nature (Lond.) 215: 778-779.

10. Wolfheim, J.H. (1983). Primates of the World: Distribution, Abundance and Conservation. University of Washington Press, Seattle and London. 
The IUCN Red Data Book

INSUFFICIENTLY KNOIVN

Galago thomasi Elliot, 1907

Order PRIMATES

Family LORISIDAE

SUMMARY This little known Bushbaby occurs north and east of the Zaire River as far east as Uganda, and inhabits a variety of dense lowland and montane forests. Little is known of its distribution, habitat, or populations, and its taxonomy is confused. It is often considered a subspecies of Galago demidovii, but is thought to have a more eastern distribution. Nocturnal and insectivorous, it is potentially vulnerable to widespread deforestation throughout its range. None are known to occur in captivity (although the picture is unclear because of the taxonomic confusion). It is listed on both the Afican Convention (Class B) and CITES (Appendix 2).

DISTRIBUTION G. thomasi has the most eastern distribution of the G. demidovii group, and is found north and east of the Zaire River in central Africa, east into Uganda, with possible records of its occurrence from Mt Marsabit in Kenya and in Malawi (8). The species appears to have a discontinuous distribution in the eastern parts of its range $(4,8)$. Its exact distribution will remain unclear while the taxonomy of the group is uncertain.

POPULATION The population sizes are unknown. The species may be common in some forests in Uganda, but is generally rare throughout eastern forests (8).

HABITAT AND ECOLOGY The species lives in a wide variety of montane and lowland forests, typically in areas of dense vegetation (T. Olson pers. comm., 1987). They are nocturnal and insectivorous, with a secondary reliance on gums or resins, and eating some seeds and fruits (8). In Uganda, they associate in large parties of 10-12 animals (8), apparently more sociable than G. demidovii (2). Births peak in December-February, with a second possible peak in June, but births can occur throughout the year $(2,8)$. Twins appear common, in contrast to the single births of $G$. demidovii $(1,2,8)$. The species makes untidy leaf nests from ground level up to $18 \mathrm{~m}$ in the vegetation, which can be shared by $3-4$ animals (8).

THREATS Since the distribution and abundance of the species is poorly known, its status cannot yet be assessed. However, the widespread deforestation of montane and central-eastern forests poses a major threat to a species requiring dense primary or secondary forest habitats, especially when populations are discontinous, isolated and exist at low densities. Deforestation for timber, charcoal production and cultivation are the primary causes of disturbance (9).

CONSERVATION MEASURES Effective management of forested areas will increase the long-term prospects for species such as G. thomasi. Bushbabies are widely used in biomedical and behavioural research (7) and thus are captured for trade, as well as for pets. The trade in the taxon therefore needs monitoring; at present CITES follows Honacki et al. (6) whose nomenclature of Galago is confused. Further information is needed on the species before adequate conservation measures can be recommended and in this regard a survey to determine the taxonomic and conservation staus of the taxon will be undertaken in the summer of 1988 by Harcourt and Bearder.

The species is included in Class B of the African Convention (1969); it may be hunted, killed, captured or collected only under special authorization granted by the competent authority.

The species is included in Appendix 2 of the 1973 Convention on International Trade in Endangered Species of Wild Fauna and Flora, trade in it between acceding nations being therefore subject to regulation and monitoring of its effects.

CAPTIVE BREEDING Not known to be kept in captivity, although the situation is unclear owing to the taxonomic confusion. 


\section{Threatened Primates of Africa}

REMARKS Description of the type specimen is given in (3), with further descriptions in $(4,5,8)$. It is distinguished from $G$. demidovii by larger size (95-120 $\mathrm{g} \mathrm{(8)} ; 130-145 \mathrm{~mm}$ in length (4)), as well as a distinctive light brown colour (4). The animals appear to move rapidly by hopping bipedally (10) rather than by running quadrapedally (1).

IUCN is grateful to Caroline Harcourt for preparing the draft data sheet of this species.

\section{REFERENCES}

1. Bearder, S.K. (1987). Lorises, bushbabies and tarsiers: Diverse societies in solitary foragers. In: Smuts, B.B., Cheney, D.L., Seyfarth, R.M., Wrangham, R.W. and Struhsaker, T.T. (Eds), Primate Societies. University of Chicago Press, Chicago.

2. Charles-Dominique, P. (1977). Ecology and Behaviour of Nocturnal Primates. Duckworth, London.

3. Elliot, D.G. (1907). Ann. Mag. Nat. Hist. 7: 189.

4. Groves, C. (1974). Taxonomy and phylogeny of prosimians. In: Martin, R.D., Doyle, G.A. and Walker, A.C. (Eds), Prosimian Biology. Duckworth, London.

5. Hill, W.C.O. (1953). Primates: Comparative Anatomy and Taxonomy. Vol. 1: Stre psirhini. Edinburgh University Press, Edinburgh.

6. Honacki, J.H., Kinman, K.E. and Koeppl, J.W. (Eds) (1982). Mammal Species of the World. A Taxonomic and Geographic Reference. Allen Press Inc. and The Association of Systematics Collections.

7. Izard, M.K. and Simons, E.L. (1986). Management of reproduction in a breeding colony of bushbabies. In: Else, J.G. and Lee, P.C. (Eds), Primate Ecology and Conservation. Cambridge University Press, Cambridge.

8. Kingdon, J. (1971). East African Mammals: An Atlas of Evolution in Africa. Vol. 1. Academic Press, London.

9. Struhsaker, T.T. (1987). Forestry issues and conservation in Uganda. Biological Conservation 39: 209-234.

10. Walker, A. (1979). Prosimian locomotor behaviour. In: Doyle, G.A. and Martin, R.D. (Eds), The Study of Prosinian Behaviour. Academic Press, New York. 


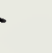




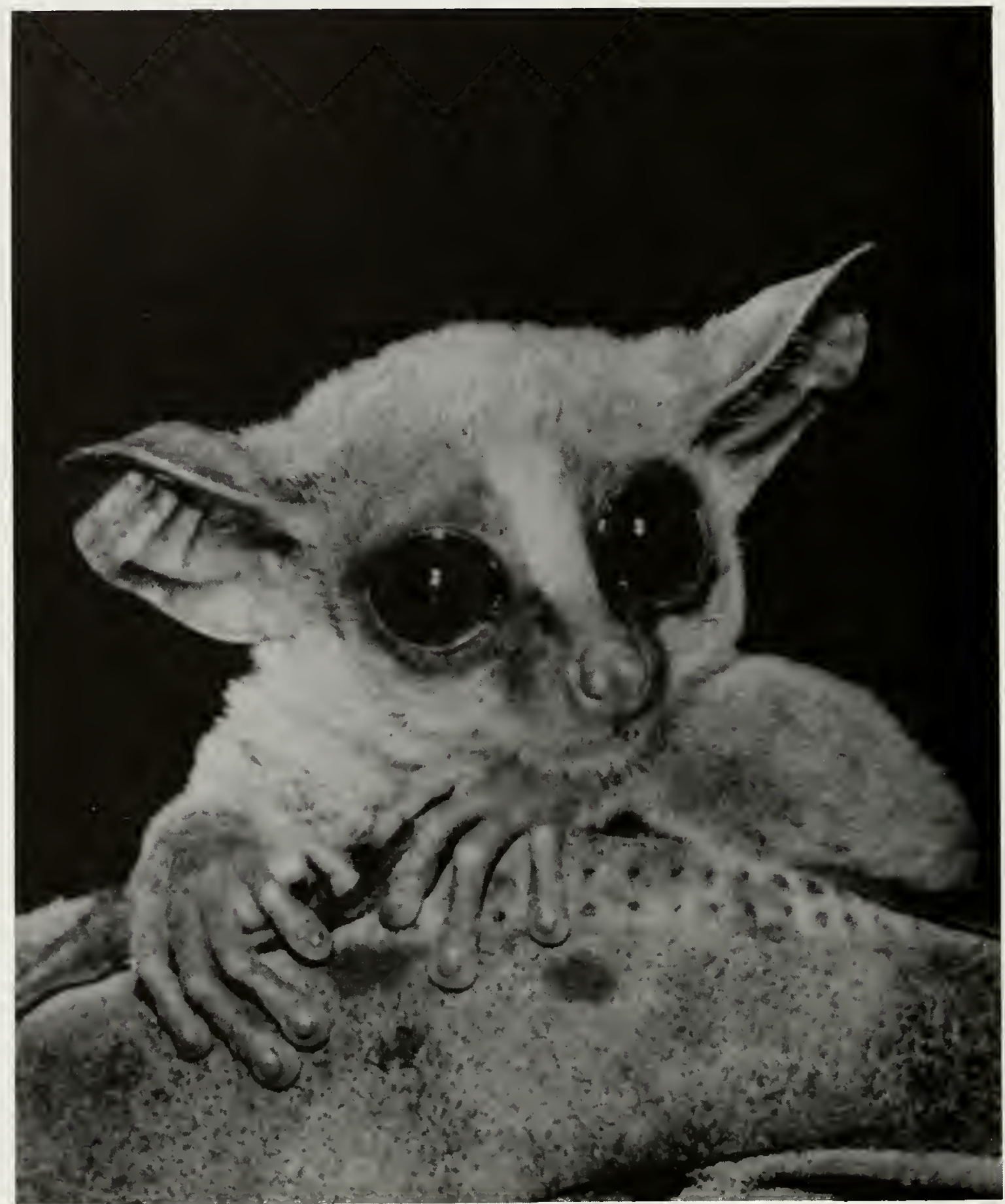

The Zanzibar Galago Galago zanzibaricus is a nocturnal prosimian found in coastal and inland forest in eastern and central-sounthern Africa. It is threatened by deforestation in much of its range.

Photo by Caroline Harcourt 
The IUCN Red Data Book

VULNERABLE

Galago zanzibaricus Matschie, 1893

Order

PRIMATES

Family LORISIDAE

SUMMARY The Zanzibar Galago can be found in lowland coastal forest in Kenya, Tanzania and on Zanzibar Island and in higher altitude forests in Tanzania and Malawi. It may occur in Mozambique but this has to be confirmed. Its distribution and population sizes remain uncertain due to confusion over its taxonomic status. In the coastal forests, habitat loss as a result of deforestation and tourist development are major threats to this nocturnal, arboreal Bushbaby. The species is protected by law in Kenya and is found in reserve areas. No information is available on its conservation status elsewhere and further studies are necessary before recommendations can be made. Due to the taxonomic confusion, it is difficult to assess the extent to which this species is housed in zoos, however the species is definitely known to have bred at Wroclaw Zoo in Poland. Included in the African Convention (Class B) and on CITES (Appendix 2).

DISTRIBUTION The species is known to occur in the coastal forests of Kenya and Tanzania, and on Zanzibar Island $(3,12)$. It is also found in high altitude forest in Tanzania (12), and in forests from the lakeshore up to $2200 \mathrm{~m}$ on the Nyika plateau in Malawi (1,6). It may occur in Mozambique (16) but this needs confirmation. Little information is available on its distribution due to confusion over the taxonomic status of the species.

POPULATION No overall estimates exist. Densitites can be high in the coastal forests of Kenya, at about 1.3 animals per ha (15) or up to 150 animals per sq. km $(5,14)$. Numbers thoughout its range, especially in the coastal forests, are thought to be decreasing along with the decline in forest cover.

HABITAT AND ECOLOGY The species can be found in both disturbed and undisturbed forest, typically in lowland coastal areas $(5,9,10)$. They are nocturnal and arboreal, tending to remain below $5 \mathrm{~m}$ in height in thick undergrowth (10). Individuals forage alone, but associate in groups of one male with one or two adult females and their offspring when sleeping in tree holes $(5,9,15)$. Home range size for both sexes is about 2.5 ha and related females tend to share territories and exlude other females from their non-overlapping ranges $(5,9,15)$. Diet consists primarily $(70 \%)$ of insects with some fruits $(5,9)$. Gestation length is approximately 120 days (4). Females can reproduce twice each year, in February/March or September/October, with a single infant each time $(5,7,13)$.

THREATS Habitat destruction, especially in the coastal forests of Kenya and Tanzania, is the major known threat. Indigenous forest is being cut and replaced by exotic conifers even in some reserve areas such as Shimba Hills National Reserve in Kenya (6). Coastal forest are also being cut to make way for developments such as hotels associated with the tourist industry (6). Although the Government of Kenya has a policy to halt deforestation, this has had little effect as yet in coastal forest. No information on the status of coastal forests in Tanzania or habitats in other areas of its range is available. Forest reserves do exist on Zanzibar Island, but the status of Galagos in these reserves has not yet been determined.

CONSERVATION MEASURES All wild animals are protected from hunting by law in Kenya, and it is illegal to keep Bushbabies as pets. The enforcement of this latter regulation is unknown. It is known to occur in the Shimba Hills National Reserve (6), and in the protected Gedi National Monument in Kenya (15). Its legal status or occurrence in protected areas in mainland Tanzania or Zanzibar Island are unknown. In Malawi it is found in one national park and at least one forest reserve $(1,6)$. Further studies are needed before adequate conservation measures can be recommended. 
All members of the Family Lorisidae are included in Class B of the African Convention (1969), and may be hunted, killed, captured or collected only under special authorization granted by the competent authority.

Listed on Appendix 2 of the 1973 Convention on International Trade in Endangered Species of Wild Fauna and Flora, trade in it between acceding nations being therefore subject to regulation and monitoring of its effects.

CAPTIVE BREEDING Due to the taxonomic confusion, it is difficult to assess if this species is kept in captivity in zoos. It has been bred in Wroclaw Zoo in Poland (4). Closely related species (e.g. G. senegalensis and $G$. demidovii) breed well in captivity (2) so it is probable that this species would also.

REMARKS For description see $(3,5,12)$. The taxon is frequently included in the distribution of $G$. demidovii (17), or as a subspecies of $G$. senegalensis (11); both Kingdon and Groves however have considered it to be a separate species $(3,12)$. Harcourt and Bearder (in press) have reviewed the differences between $G$. zanzibaricus and the South African Lesser Bushbaby (G. moholi) and confirmed that they should be regarded as two species (8).

IUCN is grateful to Caroline Harcourt who prepared the draft data sheet of this species.

\section{REFERENCES}

1. Courtenay, D.O. and Bearder, S.K. (in press). The taxonomic status and distribution of bushbabies in Malawi with emphasis on the significance of vocalisations. International Journal of Primatology.

2. Doyle, G.A., Andersson, A.B. and Bearder, S.K. (1971). Reproduction in the Lesser Bushbaby (Galago senegalensis moholi) under semi-natural conditions. Folia Primatologica 14: 15-22.

3. Groves, C.P. (1974). Taxonomy and phylogeny of prosimains. In: Martin, R.D., Doyle, G.A. and Walker, A.C. (Eds), Prosimian Biology. Duckworth, London.

4. Gucwinska, H. and Gucwinski, A. (1968). Breeding the Zanzibar Galago, Galago senegalensis zanzibaricus, at Wroclaw Zoo. International Zoo Yearbook 8: 111-114.

5. Harcourt, C.S. (1984). The behaviour and ecology of galagos in Kenyan coastal forest. Ph.D thesis, University of Cambridge.

6. Harcourt, C.S. (1985). Pers. obs.

7. Harcourt, C.S. (1986). Galago zanzibaricus: Birth seasonality, litter size and perinatal behaviour of females. Journal of Zoology, London 210: 451-457.

8. Harcourt, C.S. and Bearder, S.K. (in press). A comparison of Galago zanzibaricus in Kenya with Galago moholi in South Africa. International Journal of Primatology.

9. Harcourt, C.S. and Nash, L.T. (1986). Social organization of galagos in Kenyan coastal forests: I. Galago zanzibaricus. American Journal of Primatology 10: 339-355.

10. Harcourt, C.S. and Nash, L.T. (1986). Species differences in substrate use and diet between sympatric galagos in two Kenyan coastal forests. Primates 27(1): 41-52.

11. Hill, W.C.O. (1953). Primates: Comparative Anatomy and Taxonomy, Vol. 1: Stre pshirhini. Edinburgh University Press, Edinburgh.

12. Kingdon, J. (1971). East African Mammals: An Atlas of Evolution in Africa. Vol. 1. Academic Press, London.

13. Nash, L.T. (1983). Reproductive patterns in Galagos (Galago zanzibaricus and Galago garnettii) in relation to climatic variability. American Journal of Primatology 5: 181-196.

14. Nash, L.T. (1984). Pers. comm.

15. Nash, L.T. (1986). Social organization of two sympatric galagos at Gedi, Kenya. In: Else, J.G. and Lee, P.C. (Eds), Primate Ecology and Conservation. Cambridge University Press, Cambridge.

16. Olson, T. (1984). Pers. comm.

17. Petter, J. and Petter-Rousseaux, A. (1979). Classification of the Prosimians. In: Doyle, G.A. and Martin, R.D. (Eds), The Study of Prosimian Behaviour. Academic Press, London. 


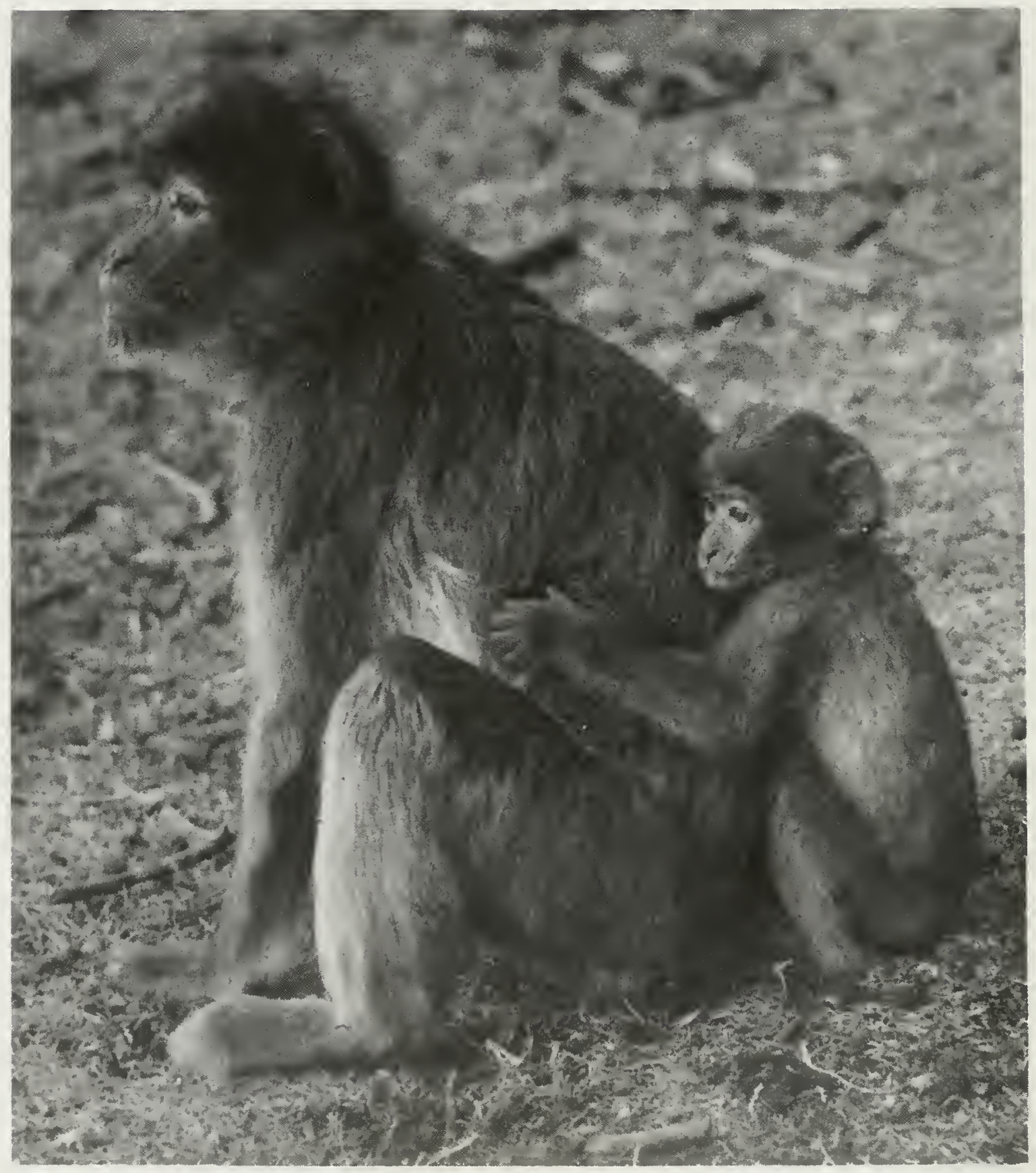

The Barbary Macaque Macaca sylvanus is the only African representative of its genus. It is threatened by widespread deforestation of cedar forests in Northern Africa.

Photo by Russell A. Mittermeier, WWF-US. 
The IUCN Red Data Book

VULNERABLE

Macaca sylvanus (Linnaeus, 1758)

Order PRIMATES

Family CERCOPITHECIDAE

SUMMARY The Barbary Macaque was once widespread throughout North Africa but is now restricted to small patches of forest and scrub in Morocco and northern Algeria. A small feral population also occurs on Gibraltar. Population estimates vary between 9000 and about 24000 ; $75 \%$ of the wild population occurs in the Middle Atlas, Morocco. An eclectic feeder, with a marked reliance on cedar and oak forests, numbers have declined dramatically in the past century due mainly to habitat destruction and degradation. Throughout its range, remaining areas of habitat require protection. The species breeds well in captivity and attempts have been made to reintroduce surplus stock into areas where it occurred previously but is now extinct. It is listed in Class A of the African Convention and on Appendix 2 of CITES.

DISTRIBUTION Barbary Macaques are documented as historically occurring widely across north-west Africa from Morocco to Tunisia and western Libya. However, since medieval times, they have been confined to small pockets in Morocco and northern Algeria (8). The species now has a discontinuous distribution in five general regions: the High Atlas, Middle Atlas and Rif in Morocco, and the Grande Kabylie and Petite Kabylie in Algeria $(17,18,28)$. A small population occurs on Gibraltar, whose origin is unknown but which could stem from pre-glacial eras since ancient skulls were found in the 18 th century (8). The Gibraltar population has been augmented with introduced animals over the past 200 years $(8,17)$. Escapees from the Vigo Zoo were reported to survive in northern Spain in the early 1980 s (18).

Morocco The only surviving populations in the High Atlas are found in the Bou Tferda and Ourika Valleys near Marrakech $(6,8,18)$. At $31^{\circ} 18^{\prime} \mathrm{N}, 7^{\circ} 47^{\prime} \mathrm{W}$, the Ourika population represents the southern and westernmost limit of the species $(6,8,33)$. The population in the Middle Atlas is relatively continuous and extensive $(8,17,18,29)$. In the Rif, Macaca sylvanus is restricted to small forest patches primarily on Mounts Lakraa, Tissouka, Tazoute and Bouhassim (25).

Algeria The species occurs in seven small isolated regions between Blida in the west and Djijel in the east: the forests of Djurdjura, Akgfadou, Guerrouch, Mount Babor, Chiffa Gorge, Kerrata and the Pic des Singes near Bejaia $(18,21,26)$. The eastern limit of the species' range is now $5^{\circ} 41^{\prime} \mathrm{E}(21,29,32)$.

Tunisia Barbary Macaques were found in coastal forest around Tabarka until the end of the 19 th century $(22,23)$.

POPULATION Estimates of the total wild population range from 12000 to 23000 animals $(17,28,30)$. Numbers have undoubtedly declined greatly in the past century $(17,28,32)$.

Morocco The population is thought to number between 9000-17 000 (28). The majority of the total population (75\%) occurs in the Middle Atlas, where numbers are estimated to be between $15000-16000.2 \%$ of the total is found in the Rif $(17,18,28)$.

Algeria The population probably represents $23 \%$ of the overall total, at up to 5500 animals $(18,28)$.

Gibraltar The population currently numbers 68; previously, it was maintained at 30 animals by periodic removals to zoos by military authorities $(15,34)$.

The total number in captivity at the end of 1981 was greater than $900(17,27)$.

HABITAT AND ECOLOGY Barbary Macaques can live in a variety of wooded habitats, but are now confined primarily to inaccessible scrub-clad rocky areas and gorges and to montane forests $(17,28)$. They are found up to $3500 \mathrm{~m}$ in elevation $(1,8)$ in montane forests composed of 
deciduous and evergreen oaks and conifers. Cedar (Cedrus atlantica) and the oak species (Quercus ilex and Quercus faginea) can account for over $50 \%$ of all dietary intake (5). The species has an eclectic diet, tending to concentrate on fruits (33\%), with $16 \%$ tree leaves and $24 \%$ of other plant parts such as annual herbs, roots and bulbs $(2,5,9,14,35)$. Animal matter forms a small, but important part of the diet $(5,8)$. The extreme seasonal nature of the higher elevation habitats has a marked influence on diets; cedar (Cedrus atlantica) seems to be a critical resource during winter months when the availability of other foods is low (5). Groups are multi-male $(2,17,28,30)$, ranging in size from $7-40$ depending on the habitat quality $(9,17)$. In the cedar forests of Ain Kahla in the Middle Atlas, groups average 24 (2), while those in oak and fir woods in the Rif average 14 (9). In gorge habitats of the High Atlas, the mean group size was 11 (35). Home ranges vary in size from 25-1200 ha (17), depending on multiple factors such as habitat quality and food availability, the distribution of water, the degree of human disturbance and predator pressure $(5,8,17,35)$. The size of the home range increases in low resource habitats such as oak, scrub or gorge sites (5).

Breeding is seasonal, with births restricted to the spring months of February to June $(5,15)$. In the wild, births tend to follow the harsh winter months and precede summer droughts $(5,8)$. Males are noted for their frequent contacts with young infants $(4,30,36)$.

THREATS The major threat to the species is habitat destruction, although hunting may be significant in some isolated areas. Expanding human numbers and widespread logging operations have greatly reduced the area of forests in both Morocco and Algeria $(17,28)$ and the remaining essential cedar forest habitat accounts for only $4 \%$ of the land area, but contains $78 \%$ of the total Macaque population (17). Levels of logging even up to 1977 were too high for the forests to withstand $(10,21,28)$. Forests are also cut to provide local firewood and charcoal $(3,4)$. Some cedar reafforestation has occurred, but by 1988 it was still insufficient to meet the demands for timber and fuelwood (21). In forests containing Macaca sylvanus, intensive grazing by goats, sheep and cattle depresses the amount of herbaceous foods necessary for the Macaques, thereby reducing their populations further $(5,17)$. Competition between the monkeys and grazing stock has been an additional factor in the reduction of primate populations (5) and the major remaining populations are found in the higher altitude forests which tend to be more inaccessible to humans and livestock $(28,29,32)$.

The species has become rare or extinct in some areas such as eastern Kaybylie where they were hunted for meat in past centuries (23). In Morocco, Barbary Macaques have sometimes been shot as agricultural crop pests, and because they damage timber trees by stripping the bark and eating the cambium layer $(3,5)$. In general, hunting currently does not have a major effect on the populations (29), nor is the export trade a threat at present. Most of the international trade involves animals culled from the Gibraltar population $(3,32)$ or bred in captivity (17). A local trade in animals captured for pets is however an increasing threat: $10-30 \%$ of newborn infants were captured in six study groups in the Middle Atlas in 1980-1981 (6,7).

CONSERVATION MEASURES Remaining areas of habitat throughout the range of the species need protection against further exploitation. The development and maintenance of national parks and forest reserves in both Algeria and Morocco is a high priority. A further measure, that of introducing Macaca sylvanus from surplus captive stock into areas where the species was known to occur but is now extinct, has been proposed and projects are underway.

Morocco Macaca sylvanus is legally protected against hunting, trapping and other forms of exploitation (7,31). A limited system of national parks exists, and an IUCN/WWF project to survey and initiate an enlargement of the system is underway (1988) following an FAO project undertaken in 1982 (21). The Barbary Macaque is distributed in habitats which are largely unprotected and continue to be exploited for timber or livestock grazing $(11,12,16)$. The species is found in two protected areas, Talassemtane Reserve and Toubkal National Park (21). These sites require additional resources if they are to become effective protected areas; measures to improve their status have been proposed (21). To protect the small remaining populations in the Rif, Fa recommended that the forests on Mount Lakraa, Tissouka, Tazoute and Bouhassim should be made nature reserves $(9,10,12,13)$. A national park in the Middle Atlas region of Ifrane/Azrou cedar forests has also been proposed (8) and is being considered by the Forestry Service, as well as ways to reduce the degree of habitat destruction and reduce the effects of 
livestock grazing (21). Taub (28) also suggested the development of strict controls on timber operations and a programme of reforestation.

The reintroduction of captive bred Macaques from France has been attempted in four trials between 1981-1986. Over 400 animals were released (6,7). Stress factors led to the immediate loss of $15 \%$ of the animals in the 1980 project (7). The long-term success of these trials has yet to be evaluated.

Algeria Barbary Macaques are protected by law, and their killing, capture and export is prohibited (28). The majority of the Algerian population is protected within national parks or reserves: in Djurdjura National Park, Taza National Park (Guerrouch), Babor Reserve, Chrea National Park (Chiffa Gorge) and Gouraya National Park (Pic des Singes) (7,21). The major exceptions are the Akfadou and Kerrata Gorge populations where parks have been recommended (7). The Algerian parks are currently well protected and the main Macaque habitats are little disturbed or exploited (21).

Gibraltar The population of Macaques on Gibraltar is protected by law, and their killing, capture and export are strictly controlled by the British military authorities. A regional park for the upper Rock is being considered by the Gibraltar Government (19). A total of 85 Macaques were exported between 1936-1983; under British Army policy they were sent only to zoos $(7,24)$.

Tunisia Proposals to introduce Barbary Macaques have not been acted upon by the Tunisian authorities (37).

Libya Introductions of Macaques have been proposed for the Tripoli Reserve and Kouf National Park (21). IUCN is currently unaware of the outcome of these proposals.

The species is included in Class A of the African Convention (1969); it may be hunted, killed, captured or collected only on the authorization of the highest competent authority, if required in the national interest or for scientific purposes.

The Barbary Macaque is also listed on Appendix 2 of the 1973 Convention on International Trade in Endangered Species of Wild Fauna and Flora, trade in it between acceding nations being therefore subject to regulation and monitoring of its effects.

CAPTIVE BREEDING At the end of 1981, over 900 Macaca sylvanus were found in 28 captive colonies, where they breed extremely successfully (17). The majority of the captive animals are found in three zoological parks in France and West Germany run by G. de Turckheim (17). Close contact between humans and Macaques, such as a dependence on garbage, has occasionally led to illness or stress in the monkeys (17). On Gibraltar, outbreaks of communicable diseases such as pneumonia have been frequent since the $1930 \mathrm{~s}$ (7).

REMARKS For a description see (20). Although commonly called Barbary Apes because they do not have tails, they are true Macaques, and are the only African representative of this genus which is widespread in Asia.

IUCN is grateful to Graham Drucker who contributed to the drafting of this data sheet.

\section{REFERENCES}

1. Alvarez, F. and Hiraldo, F. (1975). Distribution and habitat of the Barbary Macaque (Macaca sylvana L.) in North Morocco. Donana. Acta Vertebrata 2: 253-259.

2. Deag, J.M. (1974). A study of the social behaviour and ecology of the wild Barbary Macaque (Macaca sylvanus L.). Ph.D. thesis, University of Bristol.

3. Deag, J.M. (1977). The status of the Barbary Macaque (Macaca sylvanus L.) in captivity and factors influencing its distribution in the wild. In: Rainier, H.R.H. III and Bourne, G.H. (Eds), Primate Conservation. Academic Press, New York.

4. Deag, J.M. and Crook, J.H. (1971). Social behaviour and "agonistic buffering" in the wild Barbary Macaque Macaca sylvanus L. Folia Primatologica 15: 183-200. 
5. Drucker, G.R. (1984). The feeding ecology of the Barbary Macaque and cedar forest conservation in the Moroccan Moyen Atlas. In: Fa, J.E. (Ed), The Barbary Macaque - A Case Study in Conservation. Plenum Press, New York and London.

6. Drucker, G.R.F. (1985). Ecology of the Bou Tferda gorge: A feasibility study relating to the release of captive bred mammals. Unpublished report for the Montagne de Singes Zoological Park, France.

7. Drucker, G.R.F. (1988). Pers. comm.

8. Drucker, G.R.F. (In prep.). Habitat utilization and feeding ecology of the Barbary Macaque (Macaca sylvanus L.). University of London.

9. Fa, J.E. (1982). A survey of population and habitat of the Barbary Macaque Macaca sylvanus L. in North Morocco. Biological Conservation 24: 45-66.

10. Fa, J.E. (1982). International conference for the conservation of the Barbary Macaque. Report of WWF/IUCN Project 1613. Unpublished report.

11. Fa, J.E. (1983). An analysis of status of the Barbary Macaque (Macaca sylvanus L.) in the wild - steps towards its conservation. In: Harper, D. (Ed.), Symposium on the Conservation of Primates and their Habitats. Vaughan Paper 31, University of Leicester.

12. Fa, J.E. (1983). Recommendations from the Gibralter conference on the conservation of the Barbary Macaque. IUCN/SSC Primate Specialist Newsletter 3.

13. Fa, J.E. (1984). Conclusions and Recommendations. In: Fa, J.E. (Ed.), The Barbary Macaque - A Case Study in Conservation. Plenum Press, New York and London.

14. Fa, J.E. (1984). Habitat distribution and habitat preference in Barbary Macaques (Macaca Sylvanus L.). International Journal of Primatology 5(3): 273-286.

15. Fa, J.E. (1984). Structure and dynamics of the Barbary Macaque population in Gibraltar. In: Fa, J.E. (Ed.), The Barbary Macaque - A Case Study in Conservation. Plenum Press, New York and London.

16. Fa, J.E. (1984). The Barbary Macaque - The Future. Oryx 17(2): 62-67.

17. Fa, J.E. (1986). Balancing the wild/captive equation - the case of the Barbary Macaque (Macaca sylvanus L.). In: Benirschke, K. (Ed.), Primates: The Road to Self-Sustaining Po pulations. Springer-Verlag, London.

18. Fa, J.E., Taub, D.M., Menard, N. and Stewart, P.J. (1984). The distribution and current status of the Barbary Macaque in North Africa. In: Fa, J.E. (Ed), The Barbary Macaque - A Case Study in Conservation. Plenum Press, New York and London.

19. Finlayson, C. (1988). In litt.

20. Hill, W.C.O. (1974). Primates: Comparative Anatomy and Taxonomy, Vol. VII: Cerco pithecoidea. Edinburgh University Press, Edinburgh.

21. IUCN (1988). Draft Directory of the Protected Areas in North Africa.

22. Joleaud, L. (1926). Les vestiges des anciennes associations biologiques de la Berberie. Compte Rendue Congr. Int. Geogr. Le Caire IV: 128-1930.

23. Joleaud, L. (1931). Etudes de geographie zoologique sur la Berberie. Les primates: Le Magot. Congr. Inter. de Geog. Paris, Trav sect. III.

24. Mack, D. and Mittermeier, R.A. (Eds) (1984). International Trade in Primates. Traffic (U.S.A.).

25. Mehlman, P.T. (1984). Aspects of the ecology and conservation of the Barbary Macaque in the fir forest habitat of the Moroccan Rif mountains. In: Fa, J.E. (Ed.), The Barbary Macaque - A Case Study in Conservation. Plenum Press, New York and London.

26. Menard, N., Amroun, M., Mohamed Said, R. and Gautier-Hion, A. (1986). Status of the Barbary Macaque (Macaca sylvanus) in Tikjda Forest, Algeria. Primate Conservation 7: 35-38.

27. Stevenson, M. (1984). The sense and direction of captive breeding programmes - the position of the Barbary Macaque. In: Fa, J.E. (Ed.), The Barbary Macaque - A Case Study in Conservation. Plenum Press, New York and London.

28. Taub, D.M. (1975). A report on the distribution of the Barbary Macaque in Morocco and Algeria. Unpublished report.

29. Taub, D.M. (1977). Geographic distribution and habitat diversity of the Barbary Macaque (Macaca sylvanus L.). Folia Primatologica 27: 108-133.

30. Taub, D.M. (1978). Aspects of the Biology of the Wild Barbary Macaque (Macaca sylvanus L.): Biogeography, the Mating System and Male-Infant Associations. Ph.D. thesis, University of California, Davis.

31. Taub, D.M. (1978). The Barbary Macaque in North Africa. Oryx 14(3): 245-254. 
32. Taub, D.M. (1984). A brief historical account of the recent decline in geographic distribution of the Barbary Macaque in North Africa. In: Fa, J.E. (Ed.), The Barbary Macaque - A Case Study in Conservation. Plenum Press, New York and London.

33. Wolfheim, J.H. (1983). Primates of the World: Distribution, Abundance, and Conservation. University of Washington Press, Seattle and London.

34. Burton, F.D. and Sawchuk, L.A. (1974). Demography of Macaca sylvanus of Gibraltar. Primates 15: 271-278.

35. Drucker, G.R.F. (1985). The leopards of Bou Tferda gorge. Report prepared for the Eaux et Fôrets Department, Rabat.

36. Taub, D.M. (1982). Sexual behaviour of wild Barbary Macaque males (Macaca sylvanus). American Journal of Primatology 2: 109-115.

37. Portas, P. (1982). In litt. 


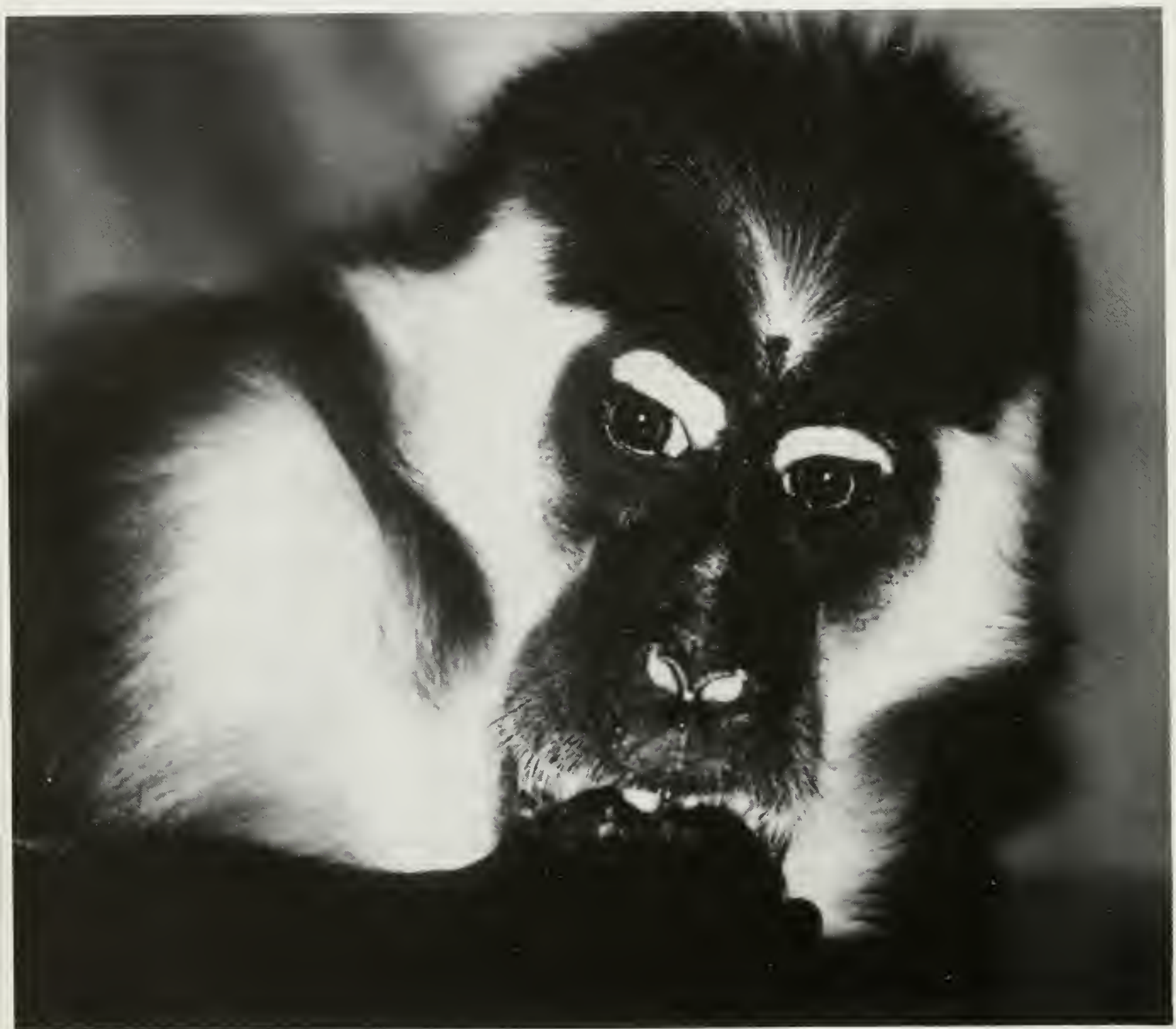

Figure 4: The Red-Capped Mangabey Cercocebus torquatus is a semi-terrestrial, frugivorous species living in high canopy rain forest from Nigeria to Congo. It is threatened by hunting and habitat destruction throughout its range.

Photo by Russell A. Mittermeier, WWF-US. 
The IUCN Red Data Book

VULNERABLE

\author{
Cercocebus torquatus (Kerr, 1792)
}

Order PRIMATES

Family CERCOPITHECIDAE

SUMMARY The Red-Capped Mangabey inhabits primary forest in Equatorial Africa from Nigeria to Congo (Brazzaville). Total numbers are unknown. It is threatened by habitat destruction and hunting. Some protected areas contain the species, but many of these areas are under increasing pressure from logging, and hunting is extensive. The species is semi-terrestrial and frugivorous, dependent on high canopy forests and living in relatively large groups. It breeds well in captivity and is listed on Class B of the African Convention and on Appendix 2 of CITES.

DISTRIBUTION C. torquatus is found in Nigeria, southern Cameroon, Rio Muni (Equatorial Guinea), Gabon and Congo (Brazzaville) $(6,28)$. In Nigeria, it is distributed throughout the south $(11,19,23)$, with a western limit in the relict forests near the Dahomey Gap (11). It is restricted to southern Cameroon, but occurs throughout Rio Muni, Gabon and Congo (Brazzaville), its southern limit being the Congo River (28).

POPULATION No overall population estimates exist. It was considered uncommon in Nigeria in 1982 (19). In Cameroon, it was reported to be common in Doula-Edea and Korup Reserves in 1972 (25). It was thought to be locally abundant, but declining in all areas of Rio Muni in 1974 (13). No estimates are available from Gabon, but it may be abundant in the Sette-Cama Forest area (29). A 1982 assessment of threats to African primates considered this species to be susceptible to a decline in numbers (20).

HABITAT AND ECOLOGY C. torquatus is primarily resident in high canopy primary forest areas $(6,11)$. However, it is also found in mangrove, gallery and inland swamp forests (28), as well as young secondary forests and around cultivated areas $(14,23,28)$. It occurs in relict forests in the derived savannah zone of western Nigeria (11). Group size in Rio Muni was reported to be 14-23 animals; larger groups contained several males and subgrouping was observed (14). In common with many Mangabey species, $C$. torquatus forms polyspecific associations with other primates $(10,14)$. The species is semi-terrestrial $(10,14)$ and primarily frugivorous, but may eat significant amounts of animal matter (14). It is considered to be a major agricultural pest and commonly forages for fruit in plantations (14). Home ranges are large, and groups forage over greater areas in the dry season than in the rains (14). Little is known of reproductive parameters in the wild.

THREATS Habitat destruction and hunting are major threats throughout most of its range; conflict with humans over crop raiding in agricultural areas is an additional pressure.

Nigeria C. torquatus is hunted extensively, particularly in the west where it had become very rare by 1973 (11). Much of the forest in southern Nigeria has been reduced to small patches which continue to be exploited for timber extraction (both legal and illegal), oil extraction, and hunting, and to be cleared for cultivation or plantations $(2,18,19)$.

Cameroon Selective logging and forest clearance have been extensive since the early 1960 s, and reforested areas are often planted with unpalatable exotics (8). Commercial logging and its attendent developments such as roads open new areas for cultivation and increase hunting pressures to supply local workers (8).

Equatorial Guinea In Rio Muni virtually all commercially valuable timber had been removed by 1972 (25). No current information is available on either hunting pressures or the nature and extent of forestry in primate habitats.

Gabon Large areas of relatively undisturbed forest remain intact, but hunting pressures are intense in areas of human habitation $(7,29)$. 
Congo (Brazzaville) Game meat is the second most important source of local protein (after fish), and hunting is widespread $(24,27)$. Verschuren (1982) has stated that continued high levels of hunting could lead to the creation of a "zoological desert" (27). Much of the forest has been destroyed and replaced with fire-maintained grasslands (24). Even within reserve areas, illegal logging continues (24).

CONSERVATION MEASURES Practical and effective controls on hunting of $C$. torquatus are needed throughout its distribution. The protected status of forest reserves also needs enforcement. Education programmes designed to alert residents to the effects of hunting, and to minimize conflict between agriculturalists and the Mangabeys should also be initiated.

Nigeria The species can only be hunted or exported with a permit from the Chief Game Warden (15); this needs to be enforced. The Okomu Forest Reserve is within the range of the species and a wildlife sanctuary of $67 \mathrm{sq} . \mathrm{km}$ in the centre of the reserve was declared in 1985 (30) within which hunting and tree-felling are prohibited $(2,19)$.

Cameroon Permits are required to trap or export the species (15). It occurs in the Douala-Edea, Campo, and Dja Reserves and in Korup National Park $(10,25)$. Douala-Edea has been proposed as a national park (9) and illegal loggers were expelled in 1976 (3); oil exploration was a threat in 1983 (1). Campo Reserve has been heavily logged and further exploitation is planned (1). The Dja Reserve in south-central Cameroon has also been proposed as a national park (1). Korup National Park in the south-west appears to have low levels of hunting (25) and contains several threatened species of primate. The development of the park is being financed by a grant from the British Overseas Development Agency and from World Wide Fund for Nature (U.K.). An extensive conservation education programme was conducted in its vicinity between 1981-1983 (22).

Equatorial Guinea The species is not protected by law and does not occur in a protected area.

Gabon While $C$. torquatus can only be exported with a permit from the Director of Wildlife and Hunting (15), it is not protected from hunting (29). It is listed as occurring only in the Sette Cama Forest Reserve and appears to be absent from most other forest reserve areas (29).

Congo (Brazzaville) Wildlife protection is administered by the Ministère des Eaux et Forêts; however their task is restricted by lack of adequate budget and staff, thus legal protection cannot be effectively enforced $(24,27)$. Without considerable outside assistance and funding, the situation is unlikely to improve (24). The presence of $C$. torquatus within protected areas is unknown.

C. torquatus is included in Class B of the African Convention (1969); it may be hunted, killed, captured or collected only under special authorization granted by the competent authority.

It is also listed in Appendix 2 of the 1973 Convention on International Trade in Endangered Species of Wild Fauna and Flora (CITES), trade in it between acceding nations being therefore subject to regulation and monitoring of its effects.

CAPTIVE BREEDING In 1983, 9 were bred in four collections, at least some of which were second generation births (21).

REMARKS C. torquatus is here considered a monotypic species following $(4,5,11,16,26)$, and Cercocebus atys atys and $C$. a. lunulatus are considered a distinct species. However, some authorities $(12,17)$ place both atys and lunulatus in $C$. torquatus, it then having three subspecies. For description see (6).

\section{REFERENCES}

1. Agland, P.C. (1983-84). Pers. comm.

2. Anadu, P.A. and Oates, J.F. (1982). The status of wildlife in Bendel State, Nigeria, with recommendations for its conservation. Report of IUCN/WWF Project 1613.

3. Anon. (1976). Cameroon rainforest. Oryx 13(4): 340. 
4. Booth, A.H. (1956). The Cercopithecidae of the Gold and Ivory Coasts: Geographic and systematic observations. Ann. Mag. Nat. Hist. 12: 476-480.

5. Booth, A.H. (1958). The zoogeography of West African primates: A review. Bull. Inst. Fondam. Afr. Noire 20: 587-622.

6. Dandelot, P. (1974). Part 3: Order Primates. In: Meester, J. and Setzer, H.W. (Eds), (1971-77). The Mammals of Africa: An Identification Manual. Smithsonian Institution Press, Washington, D.C.

7. Gandini, G. (1979). In litt.

8. Gartlan, J.S. (1975). The African coastal rain forest and its primates - threatened resources. In: Bermant, G. and Lindburg, D.G. (Eds), Primate Utilization and Conservation. John Wiley and Sons, New York.

9. Gartlan, J.S. and Agland, P.C. (1980). A proposal for a program of rain-forest conservation and national park development in Cameroun, West-Central Africa. Unpublished report to the Gulf Oil Corporation.

10. Gartlan, J.S. and Struhsaker, T.T. (1972). Polyspecific associations and niche separation of rain-forest anthropoids in Cameroon, West Africa. Journal of Zoology 168: 221-266.

11. Happold, D.C.D. (1973). The Red Crowned Mangabey, Cercocebus torquatus, in Western Nigeria. Folia Primatologica 20: 423-428.

12. Honacki, J.H., Kinman, K.E. and Koeppl, J.W. (1982). Mammal Species of the World. Allen Press Inc. and the Association of Systematics Collections, Lawrence, Kansas.

13. Jones, C. (1974). Pers. comm. In: Wolfheim, J.H. (1983), Primates of the World: Distribution, Abundance and Conservation. University of Washington Press, Seatle and London.

14. Jones, C. and Sabater Pi, J. (1968). Comparative ecology of Cercocebus albigena (Gray) and Cercocebus torquatus (Kerr) in Rio Muni, West Africa. Folia Primatologica 9: 99-113.

15. Kavanagh. M. and Bennett, E.L. (1984). A synopsis of legislation and the primate trade in habitat and user countries. In: Mack, D. and Mittermeier, R.A. (Eds), International Trade in Primates. TRAFFIC (U.S.A.).

16. Napier, J.R. and Napier, P.H. (1967). A Handbook of Living Primates. Academic Press, New York.

17. Nowak, R.M. and Paradiso, J.L. (1983). Walker's Mammals of the World. The Johns Hopkins University Press, Baltimore and London.

18. Oates, J.F. (1982). In search of rare forest primates in Nigeria. Oryx 16(5): 431-436.

19. Oates, J.F. (1983). Primates of the Nigerian rainforest. Report of Project 1613. WWF Monthly Report January: 399-402.

20. Oates, J.F., Gartlan, J.S. and Struhsaker, T.T. (1982). A framework for planning rain-forest primate conservation. International Primate Society Newsletter No. 1.

21. Olney, P.J.S. (Ed.) (1986). International Zoo Yearbook 24/25. Zoological Society of London.

22. Parrot, J. (1981). Cameroon forest parks conservation education programme, report 1980/81. Unpublished report.

23. Schlitter, D.A., Phillips, J. and Kemp, G.E. (1973). The distribution of the White-collared Mangabey, Cercocebus torquatus, in Nigeria. Folia Primatologica 19(5): 380-383.

24. Spinage, C.A. (1980). Parks and reserves in Congo Brazzaville. Oryx 15(3): 292-295.

25. Struhsaker, T.T. (1972). Rain-forest conservation in Africa. Primates 13: 103-109.

26. Tappen, N.C. (1960). Problems of distribution and adaptation of the African monkeys. Current Anthro pology 1: 91-120.

27. Verschuren, J. (1982). Republique Populaire de Congo. Relance de la conservation de la nature. Unpublished report.

28. Wolfheim, J.H. (1983). Primates of the World: Distribution, Abundance, and Conservation. University of Washington Press, Seattle and London.

29. Nicoll, M. and Langrand, O. (1986). Conservation et utilization rationnelle des ecosystemes forestiers du Gabon. Unpublished report to WWF/IUCN.

30. Oates, J.F. (1988). In litt. 


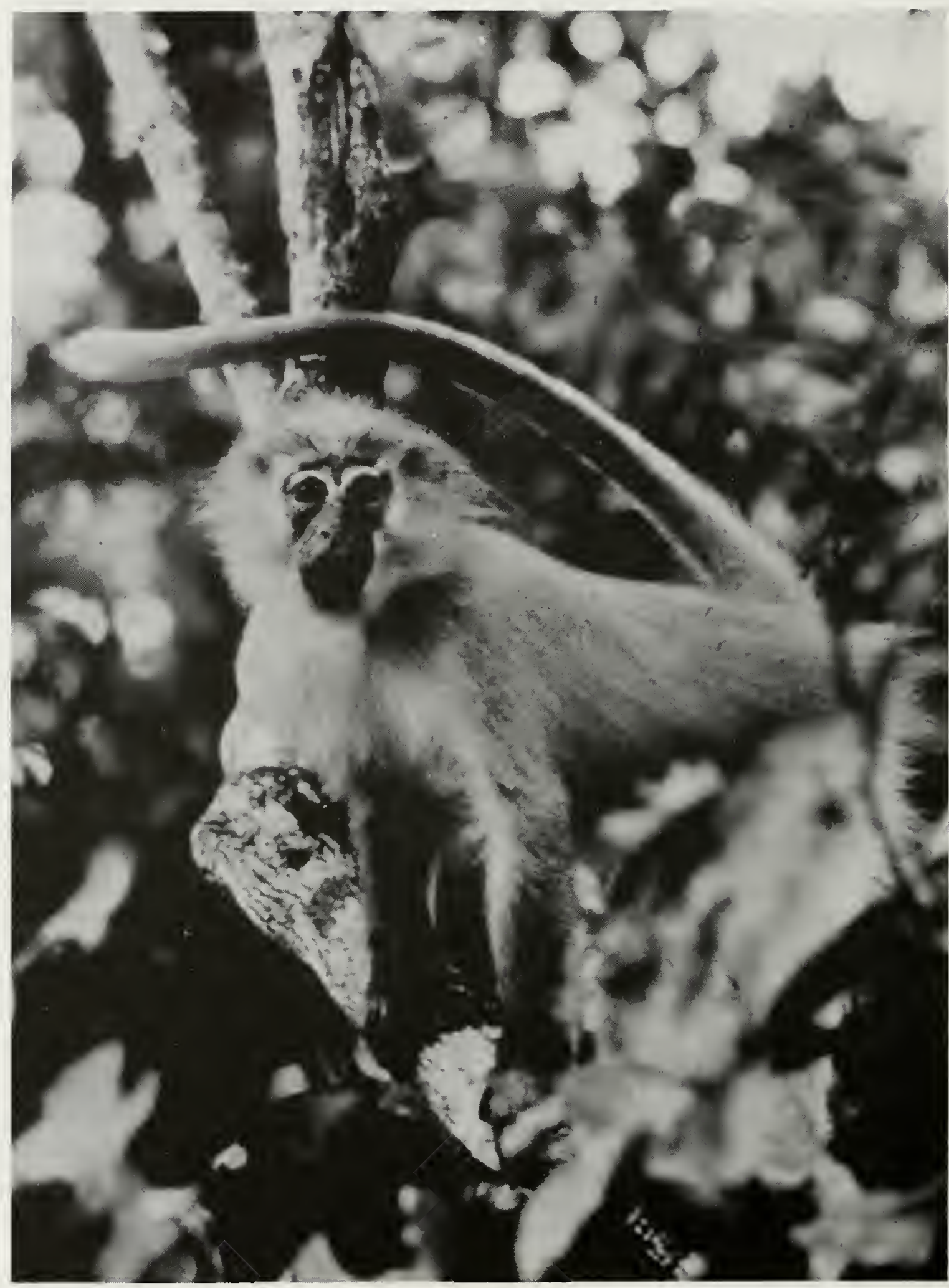

The Tana River Mangabey Cercocebus galeritus galeritus is endemic to gallery forest along the Tana River, Kenya. Numbers have declined drastically in the past 10 years as a result of changes in the river regime affecting forest regeneration.

Photo by C. Marsh. 
The IUCN Red Data Book

TANA RIVER MANGABEY

ENDANGERED

Cercocebus galeritus galeritus Peters, 1879

Order PRIMATES

Family CERCOPITHECIDAE

SUMMARY The Tana River Mangabey is endemic to small patches of gallery forest along the Tana River in Kenya. It is one of four subspecies of the Crested Mangabey, another subspecies the recently discovered Sanje Crested Mangabey is also considered to be "Endangered". The two western subspecies are little known. The Tana River population was thought to number less than 1100 in 1985. It is an opportunistic feeder with a diverse diet and flexible ranging and social behaviour. It is threatened by changes in river management of the Tana River which are causing a reduction in riverine woodland regeneration leading to loss of habitat and food species for the Mangabey. Although the majority of the population is protected within the Tana River Primate Reserve, the subspecies is unlikely to survive without effective protection of the gallery forests from human-caused changes in river regimes and habitat disturbance. It is not maintained in captivity. It is listed in Class A of the African Convention and on Appendix 1 of CITES.

DISTRIBUTION The subspecies is endemic to gallery forest along the flood plain of the Tana River, Kenya $(3,6,7,14,16)$. The known range of the taxon covers a straight-line distance of $56 \mathrm{~km}$, from Wenje in the north to Lango la Simba in the south, where the Lamu-Garsen road enters the Tana River floodpain $(3,13)$. It also occurs a short distance away from the river at Maziwa (3).

POPULATION Surveys by Clive Marsh in 1985 estimated a surviving population of only 800-1000 Mangabeys (12). This indicates a 25\% decline (12) since 1975 when similar surveys by Marsh gave minimum and maximum estimates of 1161 and $1566(13,14)$. Estimates of the population in 1972 suggested a total of 2245 animals (3), but 1000-1500 animals was thought to be a more reliable number (6).

HABITAT AND ECOLOGY The subspecies is confined to small patches of gallery forest and adjacent bush, often only a few hectares in size, that are seasonally innundated by flooding from the Tana River $(3,6,7)$. The monkeys will travel across open ground between the patches $(6,7)$. They exhibit preferences for patches dominated by Pachystela, and are found in $100 \%$ of such forest types, but only in $72 \%$ of patches dominated by Mimuso ps / Acacia (13). C. g. galeritus are behaviourally flexible and seem to be specifically adapted to a cyclic, fluctuating ecosystem (7). They are highly opportunistic feeders, eating more than 100 items of more than 50 species, the main part of the diet comprising fruits, seeds and insects, and they occasionally catch and eat small vertebrates such as frogs and lizards $(6,7)$. They are semi-terrestrial $(3,7)$ and ranging patterns vary between forest patches and seasonally, depending on the distribution of food (7). Social behaviour is also flexible; they usually live in groups of 13 to 36 individuals containing one to six adult males, but occasionally two or more groups join to form aggregations of 50 to 60 individuals (7). The reproductive rate is relatively slow: the inter-birth interval is 18 months to two years, and females attain sexual maturity at four to five years (7). There is a discrete birth season between November and February (4).

THREATS Habitat destruction by Man was once considered the major threat to $C$. g. galeritus within its very restricted range. Homewood and Marsh $(6,13,14,15)$ stated that hunting was not a problem to the animals but they identified five main threats to the forest habitat: i) Clearance for agriculture; there was a net loss of at least $16.9 \%$ of forest within the range of $C$. g. galeritus between 1960 and 1974, due mainly to clearance for shifting agriculture. ii) Large trees were felled for dugout canoes; the same trees often constituting major food sources for the Mangabeys. Marsh (14) calculated that, on average, 13 Ficus sycomorus were cut between Wenje and Mnazini each year; potentially significant as $F$. sycomorus is an important food source. iii) Grass on the floodplains adjacent to the forest is commonly burnt by pastoral tribes to stimulate growth, maintaining grassland in areas which would otherwise have developed into forest. Fires also encroach into the forest edges, possibly causing as much forest loss or conversion to bush land as does direct clearance. iv) Undergrowth of many forest patches could 
be altered by large herbivores, and this was likely to affect rates of regeneration. v) Changes to the river regime were likely to have major long-term detrimental effects on the forest. In 1978, Marsh (14) reported that two such schemes were projected upstream of the floodplain forests. First, the construction of a large reservoir affecting the height and frequency of flooding downstream. Second, a scheme to irrigate 13000 ha at Bura greatly decreasing the overall flow of the river. The effects of these schemes on the downstream ecology was not predicted accurately, but it was thought that a lowering of the water table would kill some sensitive species, and seed germination and sapling growth would decrease (14).

The resurvey in 1985 (12) demonstrated that item (V) had become the most significant threat to the habitat of the Tana River Mangabey. Since 1975 forest clearance by humans had been negligible with only two significant areas, Mnazini South and Guru West, being lost. Neither of these losses were due to human cutting but resulted from severe floods and fire (12). In contrast, the composition of the forest had changed radically between 1975 and 1985 with older trees not being replaced by younger ones. Seedlings were being produced but did not survive to the sapling stage without regular flooding. The effects of upstream damming was that occasional small floods had become infrequent whilst the occasional severe flood still occurred in the normal manner. Large floods may kill off trees by developing anoxic conditions in the soil. In addition, damming reduces the sediment load in the river; occurrence of meanders, ox-bow lakes and levée deposition become less frequent and thus reduce the potential for the regeneration of the habitat as the river becomes more entrenched in its present course (12). Increasing senescence of the forest has led to the decline of food species for the primate.

CONSERVATION MEASURES Marsh (12) recommended a study of forest regeneration to incorporate quantitative sampling of seedling, saplings and trees with experiments to establish germination and requirements for the principal species. In addition, a study of the traditional agricultural systems of the Pokomo people was recommended to assess the impact of reduced flooding on crop yields. It was suggested that the Tana and Athi Rivers Development Authority should fund and support this work. Funding is required to complete a headquarters and entrance gate for the reserve plus funding for maintenance of buildings, roads and cut lines within the reserve. Personnel for the two studies have been identified but require funding; a warden and three rangers work on the reserve but require an infrastructure.

The Tana River Game Reserve was gazetted in 1976 (1). It is about 170 sq. km $(1,16)$ and even though only $12 \mathrm{sq}$. $\mathrm{km}$ of that comprises forest, it includes the majority of the remaining population of C. g. galeritus (16). No exports of primates are allowed without the written permission of the Minister for Environment and Natural Resources (9).

C. g. galeritus is included in Class A of the African Convention, (1969); it may be hunted, killed, captured or collected only on the authorization of the highest competent authority, if required in the national interest or for scientific purposes.

C. g. galeritus is also listed in Appendix 1 of the 1973 Convention on International Trade in Endangered Species of Wild Fauna and Flora (CITES), and therefore any trade in it or its products is subject to strict regulation by ratifying nations, and trade for primarily commercial purposes is banned.

CAPTIVE BREEDING Not known to be held in captivity.

REMARKS For photographs see (7) and for description see (10).

The full species, Cercocebus galeritus, has a discontinous distribution, occurring in the Congolese forest block (2) from Cameroon through Gabon, Congo (Brazzaville), and Zaire as far east as Uganda, with two completely separated populations in East Africa, the Tana River population in Kenya and the other in the Uzungwa Mountains of Tanzania. Four subspecies are now recognized $(2,5)$ and the two distinctive East African subspecies are considered by IUCN to be "Endangered" as a result of habitat alteration within their restricted ranges $(5,11,12)$. Little is known of the status of the two western subspecies, but it is possible that they are also threatened as a result of habitat loss and hunting throughout their range-common problems to the survival of most primates in the West African forests (16); additional data are required to determine 
their status. Crested Mangabeys tend to be found in riverine forests, relying on a diet of fruits. They are semi-terrestrial and highly social. Specimens of some subspecies are held in captivity. The species as a whole is included in Class B of the African Convention and on Appendix 2 of CITES. Details of the "Endangered" Tanzanian subspecies, the Sanje Mangabey, are provided on a separate data sheet.

\section{REFERENCES}

1. Anon. (1976). Kenyans demand new reserves. Oryx 13(3): 232.

2. Dandelot, P. (1974). Part 3: Order Primates. In: Meester, J. and Setzer, H.W. (Eds), (1971-77). The Mammals of Africa: An Identification Manual. Smithsonian Institution Press, Washington, D.C.

3. Groves, C.P., Andrews, P. and Horne, J.F.M. (1974). Tana River Colobus and Mangabey. Oryx 12(5): 565-575.

4. Homewood, K.M. (1976). The Ecology and Behaviour of the Tana Mangabey. Ph.D. thesis, University College, London.

5. Homewood, K.M. and Rodgers, W.A. (1981). A previously undescribed Mangabey from southern Tanzania. International Journal of Primatology 2: 47-55.

6. Homewood, K.M. (1975). Can the Tana Mangabey survive? Oryx 13(1): 53-59.

7. Homewood, K.M. (1975). Monkey on a riverbank. Natural History 84(1): 68-73.

8. Hughes, F.M.R. (1984). A comment on the impact of development schemes on the floodplain forests of the Tana River of Kenya. The Geographical Journal 150(2): 230-244.

9. Kavanagh, M. and Bennett, E.L. (1984). A synopsis of legislation and the primate trade in habitat and user countries. In: Mack, D. and Mittermeier, R.A. (Eds), International Trade in Primates. TRAFFIC (U.S.A.).

10. Kingdon, J. (1971). East African Mammals, Volume 1. Academic Press, New York.

11. Lovett, J.C. (1983). Tanzania; habitat evaluation in Uzungwa and Usambara Mountains. Unpublished report to WWF/IUCN.

12. Marsh, C.W. (1985). A Resurvey of Tana River Primates. Report to Institute of Primate Research, Kenya and Departement of Wildlife Conservation and Management. Offset litho. $27 \mathrm{pp}$.

13. Marsh, C.W. (1978). Ecology and social organisation of the Tana River Red Colobus, Colobus badius rufomitratus. Ph.D thesis, University of Bristol.

14. Marsh, C.W. (1978). Problems of primate conservation in a patchy environment along the lower Tana River, Kenya. In: Chivers, D.J. and Lane-Petter, W. (Eds), Recent Advances in Primatology, Vol. 2. Conservation. Academic Press, London and New York.

15. Marsh, C.W. (1980). Primates and economic development on the Tana River, Kenya: The monkeys in the works. In: Furtado, J.I. (Ed.), Tropical Ecology and Develo pment: Tro pical Ecology. International Society of Tropical Ecology.

16. Struhsaker, T.T. (1972). Rain-forest conservation in Africa. Primates 13: 103-109.

17. Struhsaker, T.T. (1981). Forest and primate conservation in East Africa. African Journal of Ecology 19: 99-114. 

The IUCN Red Data Book

ENDANGERED

Cercocebus galeritus subspecies "san jei" Homewood and Rodgers, 1981

Order PRIMATES

Family CERCOPITHECIDAE

SUMMARY The Sanje Crested Mangabey was described only as recently as 1981 . It is endemic to the Uzungwa Mountains of Tanzania. It is one of four subspecies of the Crested Mangabey, another subspecies - the Tana River Mangabey, C. g. galeritus, is also considered to be "Endangered". The two western subspecies are little known. Populations of the Sanje Mangabey are estimated to be less than 3000 in a restricted area. While protected in the Mwanihana Forest Reserve, they are threatened by habitat loss due to timber extraction and charcoal production. Without adequate forest management and protection, the future of this small restricted population of Mangabeys remains in grave doubt. No captive colony exists. Cercocebus galeritus as a full species is listed on Class B of the African Convention and in Appendix 2 of CITES.

DISTRIBUTION Known from only a small area on the eastern scarp of the Uzungwa Mountains $\left(7^{\circ} 76^{\prime} \mathrm{S}, 36^{\circ} 54^{\prime} \mathrm{E}\right)$ in Tanzania. Individuals have been observed in the Mwanihana Forest Reserve at between 400-1230 $\mathrm{m}$ in elevation $(2,3)$.

POPULATION In 1981, preliminary estimates within the reserve suggested 15-16 animals per sq. km, and a total of between 1800-3000 animals (2). Homewood and Rodgers (2) thought that numbers were "satisfactory".

HABITAT AND ECOLOGY The Mangabeys appear to be restricted to the scarp forests and live in multi-male, multi-female groups of between 15-40 animals (3), averaging about 20-25 (2). They forage from ground level to the top of the canopy, possibly preferring understory vegetation with high fruit availability (2). Most feeding takes place on the ground, once fruits have been obtained (3). They have been observed foraging along stream beds (2). They are not known to raid cultivated areas (2). They form polyspecific associations with Blue Monkeys, Cercopithecus mitis, while feeding (3). The Mangabeys are sexually dimorphic and give characteristic long calls $(2,3)$.

THREATS The population is protected within the $200 \mathrm{sq} . \mathrm{km}$ Mwanihana Forest Reserve. However, pressure on the reserve is increasing in order to expand areas of cultivation and for timber and charcoal extraction (2). Much of the forest below $1000 \mathrm{~m}$ in elevation has been cut (3). All primates in the area are hunted for meat by the Wahehe people, and the Mangabeys are trapped or caught by dogs (2). They are also occasionally killed when mistaken for crop-raiding species such as Baboons, Papio anubis.

CONSERVATION MEASURES The subspecies has an extremely limited distribution and even within the reserve exists at low densities. Observations of the animals in the less disturbed forests above $1000 \mathrm{~m}$ in elevation suggest a greater area of forest may be available as habitat than was previously thought (3). However, effective management and protection of the reserve is critical to the survival of the subspecies. Practical assistance to the Forestry Department would help maintain the reserve in the face of increasing pressure for resource utilization. The reserve has been proposed as the Uzungwa National Park, which would enhance its protected status (3). Schemes for finding alternative sources of fuel wood and timber, and better equipped patrols within the reserve, combined with conservation education projects to alert local residents to the value of forests as watersheds, would assist with the conservation of the forest of the Uzungwa Mountains along with their endemic fauna. Further studies of the densities and distribution of the subspecies would be of use in determining conservation priorities.

The subspecies has no specific legal protection since it was only recently described, its inclusion in Tanzanians wildlife protection laws would be advantageous.

It is covered under C. galeritus in Class B of the African Convention (1969); thus it may be hunted, killed, captured or collected only under special authorization issued by the competent authority. 
C. galeritus is also listed in Appendix 2 of the 1973 Convention on International Trade in Endangered Species of Wild Fauna and Flora, trade in it between acceding nations being therefore subject to regulation and monitoring of its effects.

CAPTIVE BREEDING Unknown; one juvenile was kept in captivity at the Mt Meru Animal Sanctuary near Arusha in Tanzania.

REMARKS For a description see (2). Since no type specimens yet exist and the description is based on live animals only, the designation "sanjei" has not formally been accepted. The name "sanjei" is commonly associated with the subspecies at present (6).

The full species, Cercocebus galeritus, has a discontinous distribution, occurring in the Congolese forest block (1) from Cameroon through Gabon, Congo (Brazzaville), and Zaire as far east as Uganda, with two completely separated populations in east Africa, one in Kenya on the Tana River and the other in the Uzungwa Mountains of Tanzania. Four subspecies are now recognized $(1,2)$ and the two distinctive East African subspecies are considered by IUCN to be "Endangered" as a result of habitat alteration within their restricted range $(2,3,4,5)$. Little is known of the status of the two western subspecies, but it is possible that they are also threatened as a result of habitat loss and hunting throughout their range - common problems to the survival of most primates in the West African forests (7); additional data are required to determine their status. Crested Mangabeys tend to be found in riverine forests, relying on a diet of fruits. They are semi-terrestrial and highly social. Specimens of some subspecies are held in captivity. The species as a whole is included in Class B of the African Convention and on Appendix 2 of CITES. Details of the "Endangered" Tana River subspecies, C. g. galeritus, are provided on a separate data sheet.

\section{REFERENCES}

1. Dandelot, P. (1974). Part 3: Order Primates. In: Meester, J. and Setzer, H.W. (Eds), (1971-77). The Mammals of Africa: An Identification Manual. Smithsonian Institution Press, Washington, D.C.

2. Homewood, K.M. and Rodgers, W.A. (1981). A previously undescribed Mangabey from southern Tanzania. International Journal of Primatology 2: 47-55.

3. Lovett, J.C. (1983). Tanzania; habitat evaluation in Uzungwa and Usambara Mountains. Unpublished report to WWF/IUCN.

4. Marsh, C.W. (1985). A Resurvey of Tana River Primates. Report to Institute of Primate Research, Kenya and Departement of Wildlife Conservation and Management. Offset litho. $27 \mathrm{pp}$.

5. Marsh, C.W. (1980). Primates and economic development on the Tana River, Kenya: The monkeys in the works. In: Furtado, J.I. (Ed.), Tro pical Ecology and Development: Tro pical Ecology. International Society of Tropical Ecology.

6. Mittermeier, R.A. (1986). A global overview of primate conservation. In: Else, J.G. and Lee, P.C. (Eds), Primate Conservation. University of Cambridge Press, Cambridge.

7. Struhsaker, T.T. (1972). Rain-forest conservation in Africa. Primates 13: 103-109. 
The IUCN Red Data Book

INSUFFICIENTLY KNOWN

Cercocebus aterrimus (Oudemans, 1890)

Order PRIMATES

Family CERCOPITHECIDAE

SUMMARY The Black Mangabey is an arboreal primate restricted to the left bank of the Lualaba-Zaire River in central Zaire and possibly extending into Angola. The species inhabits the upper canopy levels of secondary forests, swamp forests and gallery forests. It is hunted for meat and is probably vulnerable to deforestation due to its reliance on upper layers in the canopy. Total numbers are unknown, and its distribution is uncertain. It is not known to be protected in reserves or national parks. Further information on the species is needed before adequate conservation measures can be proposed. Few animals are held in captivity. The species is listed in Class B of the African Convention and in Appendix 2 of CITES.

DISTRIBUTION The exact distribution of the Black Mangabey is still uncertain. They are known from the left bank of the Lualaba-Zaire River (5), but do not occur north of the river, where they are replaced by the Grey-Cheeked Mangabey (Cercocebus albigena) (4). The range of the species appears to be from $0^{\circ} 15^{\prime} \mathrm{S}, 20^{\circ} 51^{\prime} \mathrm{E}$ to $7^{\circ} 30^{\prime} \mathrm{S}, 17^{\circ} 30^{\prime} \mathrm{E}$, possibly as far as $9^{\circ} \mathrm{S}$ in Angola $(2,12)$. For map see (5). Two subspecies are recognised: $C$. a. aterrimus and C. a. opdenboschi (1), although the affinities of the subspecies are questioned (4).

POPULATION No information on total population size exists. They are known to be common in only two areas: near Lake Tumba $(5,12)$ and in the Haut-Zaire Province of central Zaire (12). They can be found at densities of up to 69 animals (or four social groups) per sq. $\mathrm{km}$ in those areas where they are abundant (5).

HABITAT AND ECOLOGY Black Mangabeys inhabit a variety of forest types: rain forest $(2,12)$, secondary and semi-deciduous forest $(3,5)$ and gallery and swamp forests $(5,12)$. A primarily arboreal species (12), they are active in the upper levels of the canopy from $12-30 \mathrm{~m}$ (5). The main dietary components are fruits and nuts, although insects, immature leaves and bark are also eaten (5). In the Lake Tumba area, multi-male, multi-female groups average 17-18 animals with a range of 14-19 (5). Group composition while foraging appears to be flexible, and takes place in small sub-groups (5). Home ranges are small (between $0.5-0.7 \mathrm{sq} . \mathrm{km}$ ) and overlap between groups is extensive (5). The species commonly associates with other primates, especially the Cerco pithecus species (5), as is typical of all the Mangabeys (11). Vocalizations appear to be similar to those of the closely-related Grey-Cheeked Mangabey, C. albigena, $(4,5)$. Reproductive parameters are unknown from the wild.

THREATS The main threat is hunting for meat (this is true for all primates in the central Zaire forests) $(5,10)$. Mangabeys are preferred prey, even though they are more difficult to catch than the slower moving Colobus monkeys (5). Increasing reliance on shotguns and heavy hunting pressure near villages has drastically reduced the density of all primate species $(5,10)$. The arboreal nature of the Black Mangabey is likely to make it vulnerable to forest loss $(8,12)$ and logging activities are occurring in the areas west of Lake Tumba (12). The species appears able to tolerate subsistence agriculture since it can be found in areas of secondary forest which have been disturbed by human agricultural activity for at least the last 100 years (3). However this will remain true for only as long as human densities remain low enough to allow forest regeneration in previously cultivated areas.

CONSERVATION MEASURES The species has no legal protection in Zaire and hunting of primates remains uncontrolled $(6,10)$. It is not known to occur in any protected area, although it is possible that it occurs in the Salonga National Park. The development of the Lomako Forest as a conservation area for Pygmy Chimpanzees, Pan paniscus, (9) will also protect the Black Mangabeys found there. Surveys of the distribution and conservation status of the species are needed before appropriate conservation measures can be proposed. 
The species is included in Class B of the African Convention (1969); it may be hunted, killed, captured or collected only under special authorization granted by the competent authority.

It is listed on Appendix 2 of the 1973 Convention on International Trade in Endangered Species of Wild Fauna and Flora (CITES); trade in it between acceding nations being therefore subject to regulation and monitoring of its effects.

CAPTIVE BREEDING In 1987, four adults were known to be held in captivity in the United States (5); the International Zoo Yearbook lists two males at Colorado Zoo in 1982 (7).

REMARKS C. aterrimus is sometimes considered to be a subspecies of C. albigena (see Ref. 4 for a discussion). For a description see $(2,4)$.

\section{REFERENCES}

1. Dandelot, P. (1974). Part 3: Order Primates. In: Meester, J. and Setzer, H.W. (Eds), (1971-77). The Mammals of Africa: An Identification Manual. Smithsonian Institution Press, Washington, D.C.

2. Hill, W.C.O. (1974). Primates Vol. VII. Edinburgh University Press, Edinburgh.

3. Horn, A.D. (1980). Some observations on the ecology of the Bonobo Chimpanzee (Pan paniscus Schwarz, 1929) near Lake Tumba, Zaire. Folia Primatologica 34: 145-169.

4. Horn, A.D. (1987). Taxonomic assessment of the allopatric Gray-cheeked Mangabey (Cercocebus albigena) and Black Mangabey (C. aterrimus): Comparative socioecological data and the species concept. American Journal of Primatology 12: 181-187.

5. Horn, A.D. (1987). The socioecology of the Black Mangabey (Cercocebus aterrimus) near Lake Tumba, Zaire. American Journal of Primatology 12: 165-180.

6. Kavanagh, M. and Bennett, E.L. (1984). A synopsis of legislation and the primate trade in habitat and user countries. In: Mack, D. and Mittermeier, R.A. (Eds), The International Primate Trade. TRAFFIC (U.S.A.).

7. Olney, P.J.S. (Ed.) (1986). International Zoo Yearbook 24/25. Zoological Society of London.

8. Skorupa, J.P. (1986). Responses of rainforest primates to selective logging in Kibale Forest, Uganda: A summary report. In: Benirschke, K. (Ed.), Primates: The Road to Self-Sustaining Po pulations. Springer-Verlag, London.

9. Susman, R.L. and Badrian, N. (1982). A proposed protected area for the Pygmy Chimpanzee in Zaire. IUCN/SSC Primate S pecialist Group Newsletter 2: 18.

10. Verschuren, J. (1975). Wildlife in Zaire. Oryx 13(2): 149-163.

11. Wasser, P.M. (1980). Polyspecific associations of Cercocebus albigena: Geographic variation and ecological correlates. Folia Primatologica 33: 57-76.

12. Wolfheim, J.H. (1983). Primates of the World: Distribution, Abundance and Conservation. University of Washington Press, Seattle and London. 
SUMMARY Hamadryas Baboons are found only in the Horn of Africa and on the opposite coast of the Arabian Peninsula; 90\% of the population occurs in Ethiopia. No population estimates are available, but since the species occupies semi-desert habitats, its densities are invariably low. The species is at present classed as vermin under Ethiopian legislation. Consequently, it risks persecution wherever it comes into contact with agriculture. Measures aimed at formalizing the status of the proposed conservation areas in which the species occurs are urgently needed. Hamadryas breed well in captivity. The species is classified as "vermin" under the African Convention. It is listed on Appendix 2 of CITES.

DISTRIBUTION Hamadryas Baboons are restricted to the Horn of Africa and the Arabian Peninsula $(7,11,22)$, although they are principally found in Ethiopia (22).

Ethiopia The species can be found in a wide band throughout the eastern lower-lying part of the country extending from the Sudan border in the north down through Eritrea and the eastern deserts into the Ogaden region on the Somali border (22). The most southerly known population is on the Ganale River $\left(4^{\circ} 30^{\prime} \mathrm{N}, 41^{\circ} 45^{\prime} \mathrm{E}\right)$ just north of the junction of the Kenya/Ethiopia/Somali borders (15). The western limit of its distribution is more or less defined by the western wall of the Ethiopian Rift Valley $(10,22)$.

Sudan Reported to occur in the Red Sea Hills just north of the Ethiopian border (7), but its current status is unknown.

Somalia Occurs in the north along the Red Sea littoral (22).

Djibouti Reported to occur (22) but current status unknown.

Yemen Isolated populations are reported from along the Red Sea littoral and into the Haudramaut as far east as Wadi Masila $\left(15^{\circ} 32^{\prime} \mathrm{N}, 50^{\circ} 50^{\prime} \mathrm{E}\right)(11)$.

Saudi Arabia Recent surveys have confirmed populations in several localities on the Red Sea littoral from the Yemen border as far north as Taif $\left(21^{\circ} 21^{\prime} \mathrm{N}\right)(11)$. The eastern limit is probably the edge of the Arabian desert, approximately $100 \mathrm{~km}$ inland from the coast (11).

POPULATION No estimate of total number exists. The Ethiopian population probably accounts for more than $90 \%$ of the total; this population is abundant and in no immediate danger of extinction (21). The population on the Arabian peninsula is extremely small and very scattered (11).

HABITAT AND ECOLOGY Hamadryas Baboons live in semi-desert habitats at all altitudes up to $1500 \mathrm{~m}(10,11)$. They appear to be seasonally migratory in at least some parts of their range in Ethiopia, wherebands may move up into neighbouring mountainous areas during the wet season (10). The species has been recorded regularly at altitudes of $3300 \mathrm{~m}$ in the Sinen Mountains during the wet season $(4,5)$. Since it is dependent on water, it never moves far from water sources (17). Like all Pa pio baboons, the Hamadryas is an omnivore with a preference for fruits if these are available; it may also raid crops $(10,13)$. The basic social unit is the one male unit (one breeding male with $1-3$ reproductive females and their dependent offspring), several of which associate together to form a band that typically numbers 60 animals $(10,18)$. Each band ranges over an area of c. $30 \mathrm{sq}$. km. The band usually sleeps together on a cliff or rocky outcrop, from which it disperses to forage out into the surrounding thornscrub during the day, often travelling $8-13 \mathrm{~km}$ in the process $(10,17)$. Bands seem to be less cohesive in the Saudi Arabian population, where one male units may commonly move on their own; this may reflect the virtual absence of significant predators on the Arabian Peninsula (11). The Hamadryas interbreeds 
fertilely with $P$. anubis in areas where their distributions overlap in Ethiopia (19). One hybrid zone occurs in the Awash National Park $(12,13,20)$; another is reported to occur at Goro to the south (9).

THREATS Hamadryas are not differentiated from other Papio species under Ethiopian law and are therefore classed as vermin (2), although they are protected within the confines of conservation areas (21). Hitherto, the Hamadryas's preference for arid habitats has kept it away from cultivated areas, thereby minimising its contact with Man. During the past two decades, however, development programmes have used irrigation schemes to convert the margins of the deserts in eastern Ethiopia from nomadic pastoral economies to large scale agricultural enterprises (6). This has probably tended to bring the Hamadryas into more frequent conflict with farming interests, as a result of which it is of ten killed and harassed for crop-raiding (3). It has also been exported for commercial purposes (3). At present, the Simen Mountains National Park in Ethiopia is the only gazetted park that contains a "pure" population of Hamadryas Baboons (8). The Awash National Park contains only hybrids between Hamadryas and $P$. anubis (16). Hamadryas also occur in both the proposed Yangudi Rassa National Park and the Harar Wildlife Sanctuary, as well as in a number of Wildlife Reserves in the lower Awash Valley and in northern Eritrea. The unsettled political situation in these areas makes the status of these populations uncertain and therefore a cause for concern. The fact that the lower Awash agricultural schemes all lie within the Reserve areas (1) raises potential problems over the status of the Hamadryas when they engage in crop-raiding. There are no conservation areas within the known distribution of Hamadryas in Arabia. Most of the populations surveyed (11) seem to live as commensals of Man and apparently derive a large proportion of their diet from settlement rubbish dumps. No information is available on the populations in Sudan or Somalia.

CONSERVATION MEASURES Ethiopia The primary conservation concern must be to ensure the survival and integrity of those conservation areas that contain populations of Hamadryas. Efforts must be made to formalize the status of the Yangudi Rassa National Park and the Harar Sanctuary. The relationship between development and conservation priorities in the lower Awash Valley needs to be clarified so that regulations governing the Game Reserves in this area can be properly enforced. The legal status of the Hamadryas should be reviewed: if special efforts are to be made to conserve it, it should be distinguished clearly from Common Baboons and be given full legal protection from hunting and exploitation. Surveys are needed to ascertain the population size and distribution of the species.

Arabian Peninsula The Arabian populations do not seem to differ significantly from those in Ethiopia (11), so that there may be no intrinsic reason to ensure their protection, aside from the fact that they are the only primates in Arabia. Conservation of these populations may, in any case, be difficult owing to their very low densities and dispersed distribution. The only feasible possibility would be to capture as many groups as possible and translocate them to an existing conservation area elsewhere in Arabia. The low density at which Hamadryas generally live, even in Ethiopia, constitutes the most serious problem for their future survival since very large areas are needed to provide a reasonable population for breeding.

At present, Hamadryas appear to be included with "common baboons" in the African Convention (1969); classed as vermin subject to no formal protection. In view of its status, it might be appropriate to include it in Class $\mathrm{A}$ of the Convention.

Hamadryas are also listed on Appendix 2 of the 1973 Convention on International Trade in Endangered Species of Wild Fauna and Flora, trade in it between acceding nations being therefore subject to regulation and monitoring of its effects.

CAPTIVE BREEDING Hamadryas have been bred to several generations in a number of institutions around the world (14).

REMARKS For description of animal see (7). The Hamadryas has a long history of association with Man. It earned its alternative common name, the Sacred Baboon, from its use in a formal capacity as priests in the temple of Thoth in Ancient Egypt (7). It appears on many murals in pyramid tombs and other Egyptian monuments of the period. 
IUCN is grateful to Dr Robin Dunbar who prepared the data sheet for this species.

\section{REFERENCES}

1. Anon. (1975). Safari Ethiopia. Ethiopian Government Wildlife Conservation Organization, Addis Ababa.

2. Berhanu, L. (1976). Present status of primates in Ethiopia and their conservation. Proceedings of 5th Congress of the International Primatological Society. Karger, Basel.

3. Berhanu, L. and Iwamoto, M. (1977). The distributional states of Cercopithecoid primates in Ethiopia. In: Kawai, M. (Ed.), Report of Kyoto University Primate Expedition in Ethio pia 1975-76. Primate Research Institute, Inuyama.

4. Crook, J.H. and Aldrich-Blake, F.P.G. (1968). Ecological and behavioural contrasts between sympatric ground dwelling primates in Ethiopia. Folia Primatologica 8: 192-227.

5. Dunbar, R.I.M. and Dunbar, P. (1974). Mammals and birds of the Simien Mountains National Park. Walia 5: 4-5.

6. Hill, G., Hill, M., Santi, G. and Robertson, L. (1970). Dubte plantation check list of birds. Walia 2: 41-65.

7. Hill, W.C.O. (1970). The Primates, Comparative Anatomy and Taxonomy. VIII. Cyno pithecinae. Edinburgh University Press, Edinburgh.

8. Hurni, H. (1986). Management Plan: Simen Mountains National Park and surrounding Area. Ministry of Agriculture, Natural Resourcers Conservation and Development Main Department; Wildlife Conservation Organisation; Unesco World Heritage Committee.

9. Iwamoto, M. (1980). On the distribution of baboons in Ethiopia. Journal of the Anthro pological Societ y of Nippon 88: 387-396.

10. Kummer, H. (1968). Social Dynamics of Hamadryas Baboons. Karger, Basel.

11. Kummer, H., Banaja, A.A., Abo-Khatwa, A.N. and Ghandour, A.M. (1981). A survey of Hamadryas Baboons in Saudi Arabia. Fauna of Saudi Arabia 3: 441-471.

12. Müller, H. (1980). Variations of Social Behaviour in a Baboon Hybrid Zone (Papio anubis x Papio hamadryas) in Ethio pia. Ph.D. thesis, University of Zurich.

13. Nagel, U. (1973). A comparison of Anubis Baboons, Hamadryas Baboons and their hybrids at a species border in Ethiopia. Folia Primatologica 19: 104-165.

14. Olney, P.J.S. (Ed.) (1982). International Zoo Yearbook 22. Zoological Society of London.

15. Reynolds, G.W. (1954). Notes on the aloes of southern Ethiopia and Somalia. Journal of the East African Natural History Society 22: 102-104.

16. Shotake, T. (1977). Gene exchange and genetic distance between Papio anubis, Papio hamadryas and their hybrids. In: Kawai, M. (Ed.), Report of Kyoto University Primate Expedition in Ethio pia, 1975-76. Primate Research Institute, Inuyama.

17. Sigg, H. and Stolba, A. (1981). Home range and daily march in a Hamadryas Baboon troop. Folia Primatologica 36: 40-75.

18. Sigg, H., Stolba, A., Abegglen, J.-J. and Dasser, V. (1982). Life history of Hamadryas Baboons: Physical development, infant mortality, reproductive parameters and family relationships. Primates 23: 473-487.

19. Starck, D. and Frick, H. (1958). Beobachtungen an aethiopischen primaten. Zool. Jb. (Syst.) 86: 41-70.

20. Sugawara, K. (1979). Sociological study of a wild group of hybrid baboons between Papio anubis and $P$. hamadryas in the Awash Valley, Ethiopia. Primates 20: 21-56.

21. Teshome Ashine (1985). In litt.

22. Yalden, D.W., Largen, M.J. and Kock, D. (1977). Catalogue of the mammals of Ethiopia. 3. Primates. Monitore Zoologica Italiano 9: 1-52. 


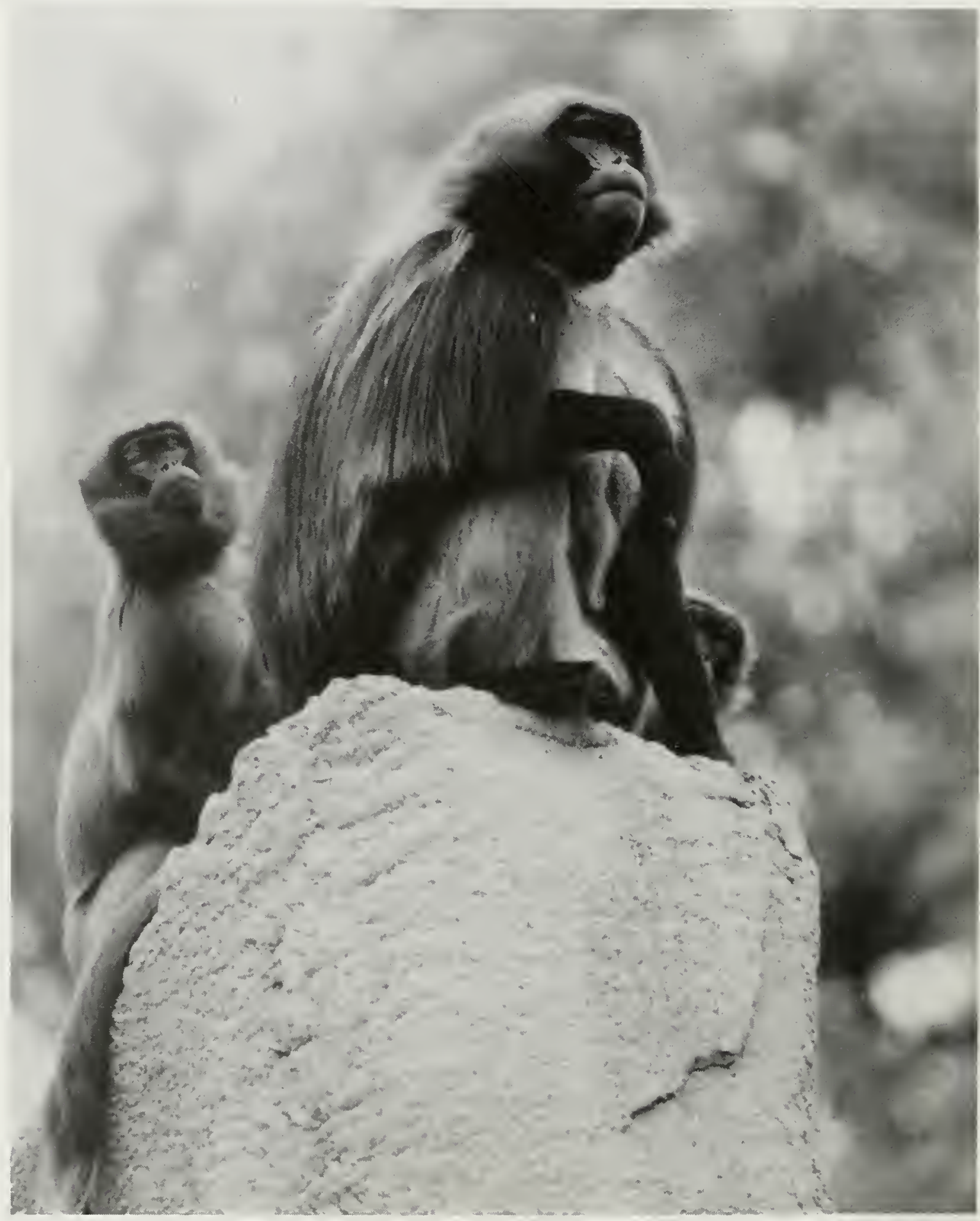

The Gelada Baboon Thero pithecus gelada is a specialised grass-eater, confined to high elevation plateaux of Ethiopia. It is a rare species, currently protected in only one conservation area. Photo by Russell A. Mittermeier, WWF-US. 
The IUCN Red Data Book

RARE

Theropithecus gelada (Rüppell, 1835)

Order PRIMATES

Family CERCOPITHECIDAE

SUMMARY Gelada Baboons are found only in the central highlands of Ethiopia. The total population was thought to number around 500000 in the early 1970 s, but may have declined during the droughts of the 1980s. Socially flexible and highly dependent on grass, the species is currently protected within only one conservation area, and is vulnerable to changes in development priorities within its restricted distribution. An increased agricultural production is critical for a country faced with shortages of arable land, periodic droughts and consequent famines. Integration of conservation priorities and development needs are essential for the survival of Gelada Baboons. The possibility of establishing another suitable conservation area in uninhabited regions should be explored. The species breeds well in captivity. It is listed on Class A of the African Convention and on Appendix 2 of CITES.

DISTRIBUTION The species is restricted to Ethiopia and is found only in the deep gorges of the central plateau, in the Provinces of Tigre, Begemdir, Wolo and Shewa $(5,8,23,24)$. It is not found in Gojjam Province on the western bank of the Blue Nile, despite the inclusion of this area in distribution maps (e.g. 8,19), since the species cannot cross the river gorge (24). Two subspecies are sometimes distinguished $(8,24)$ : the southern race, $T$. g. obscurus, is darker and smaller than the northern $T$. g. gelada (8). The boundary between the subspecies appears to lie between $10^{\circ}$ and $11^{\circ} \mathrm{N}$, but this may reflect the inaccesibility of the mountains in that region (24).

POPULATION Surveys in a number of areas give overall densities varying between 15 and 60 animals per sq. $\mathrm{km}(2)$, although densities of animals within home ranges commonly exceed 70 per sq. $\mathrm{km}$ (10). An aerial survey of the central Ethiopian highlands during the early 1970s yielded an estimate of 440000 for the total population (22). An alternative estimate based on known ground densities and the total area of gorge face on the plateau yielded a figure of 880000 (5). The true value probably lies somewhere between these two extremes. Although numbers may have declined recently due to the droughts that have affected the Horn of Africa during the 1980s, the species was reported in 1985 to be abundant throughout its present range (21).

HABITAT AND ECOLOGY The Gelada occurs exclusively in montane grasslands at altitudes of between 2000 and $4400 \mathrm{~m}$ above sea level $(5,24)$. It seldom enters forested areas and rarely climbs trees, being a poor climber $(2,4)$. It is probably the most terrestrial of all the primates, spending c. $99 \%$ of its time on the ground $(5,11)$. This is partly a consequence of its extreme dietary specialization as a grazer (7): all populations so far studied have diets thet are more than $90 \%$ grass, the bulk of this being grass blades $(4,10)$. In most areas, Gelada can be observed in large herds of up to 600 individuals $(1,3,13)$. Herds are, however, loosely structured and may form or break up easily, according to local habitat conditions $(1,6)$. The basic unit of population is the band, which consists of 50-250 animals formed into 2-30 one male reproductive units with 1-3 associated all-male groups (14). Each band occupies a home range that overlaps extensively with those of neighbouring bands (14). The core areas of primary use are $1-3 \mathrm{sq} . \mathrm{km}$ in size (10), but bands may wander widely over areas of up to $10 \mathrm{sq} . \mathrm{km}(3,13)$. Day journeys are short $(1-2 \mathrm{~km})$ and rarely involve movements of more than $0.5 \mathrm{~km}$ away from the safety of the gorge sides $(1,13)$. Gelada depend on access to cliffs for refuge from predators (now mainly native dogs and other canids) and for sleeping sites $(1,6)$. Although a long-established commensal of Man in the heavily populated central highlands, the Gelada seldom raids crops preferring to pick over abandoned threshing floors for fallen grain (1).

THREATS Increasing density of human population on the central highlands continues to place more and more land under cultivation: the human population has been growing at a rate of $2-3 \%$ per year for the last two decades at least (with some evidence to suggest that the rate has been accelerating with time) and virgin land has been put under cultivation at a similar rate (18). 
Deforestation and soil erosion are serious problems throughout the area (25). Grazing pressure is intense and competition from domestic stock has forced the Gelada to remain on the less productive gorge slopes in some areas (5). Gelada densities are considerably lower in heavily populated areas than in undisturbed habitats (5). The species is not hunted to any significant extent, though intermittent shooting of males occurs in the southern part of the species' range, largely for ritual purposes (5). Only one conservation area (the Simen Mountains National Park) contains Gelada (5). Although encroachments into the Park have been very serious in the past, the problem was brought under control during the mid-1970s. The war in northern Ethiopia forced the temporary closure of the Park in 1976, but an improving political situation has recently permitted the wildlife authority to press ahead with management plans. Most of the villages within the Park have been resettled elsewhere (21).

CONSERVATION MEASURES Gelada have been protected from hunting within conservation areas for more than a decade under Ethiopian legislation. The species' long-term future however, could be threatened by the more general problems associated with the high density and growth rate of the human population. Continued protection within established conservation areas is therefore essential (5). The Simen Mountains National Park (a Unesco World Heritage Site) has been given considerable support over the years (notably by WWF and the Swiss Pro-Simen Foundation) but it remains vulnerable to a variety of outside pressures because of its small size $(15,16)$. A management plan has being drawn up by the UNESCO World Heritage Committee (9). Every means should be adopted to ensure the integrity and survival of the Park which also includes virtually the entire population of the highly endangered Walia Ibex, Capra walia (16). Essential measures should include the introduction of a land-use programme that takes into account the needs of the local human population, improvements in agricultural practices using simple technology, the planting of trees for firewood, enforcement of the Park's boundaries and control over tree-cutting and the ploughing of new land within a buffer zone around the Park $(15,16)$. Ideally, there ought to be at least one other conservation area holding a population of the species, but at present no other suitable areas are earmarked as possible sites for conservation. It has been suggested (5) that a population of Gelada be translocated to another existing conservation area within Ethiopia. Such a measure seems unnecessary at the current time, and detailed surveys would be necessary to assess the feasibility of this proposal. An alternative possibility would be to consider establishing a new reserve or park within the spectacular Blue Nile gorge where Gelada now occur. Though difficult for access, the main gorge in the upper reaches has the advantage of being virtually uninhabited.

The species is listed in Class A of the African Convention, (1969); it may be hunted, killed, captured or collected only on the authorization of the highest competent authority, if required in the national interest or for scientific purposes.

It is also listed on Appendix 2 of the 1973 Convention on International Trade in Endangered Species of Wild Fauna and Flora, trade in it between acceding nations being therefore subject to regulation and monitoring of its effects.

CAPTIVE BREEDING Gelada have been successfully bred to several generations at a number of institutions around the world (17).

REMARKS For description see $(8,23)$. There has been some uncertainty about the taxonomic affinities of the Gelada, but it is now generally accepted that it constitutes a unique monotypic genus that is most closely related to the African baboons (Papio spp.) (11,20). Included in the genus Theropithecus are at least three extinct species that were once widely distributed throughout the savannah grasslands of Africa from the Cape of Good Hope to the Mediterranean. The last of these became extinct as recently as 50000 years ago, leaving the small and somewhat primitive Gelada as the sole surviving representative of the taxon (11). The Gelada is thought to be the original model on which the Egyptian Great Sphinx of Gaza was based (12).

IUCN is grateful to Robin Dunbar who prepared the draft data sheet for this species 


\section{REFERENCES}

1. Crook, J.H. (1966). Gelada Baboon herd structure and movement: A comparative report. Symposium of the Zoological Society of London 18: 237-258.

2. Dunbar, R. and Dunbar, P. (1974). Ecological relations and niche separation between sympatric terrestrial primates in Ethiopia. Folia Primatologica 21:36-60.

3. Dunbar, R. and Dunbar, P. (1975). Social Dynamics of Gelada Baboons. Karger, Basel.

4. Dunbar, R.I.M. (1977). Feeding ecology of Gelada Baboons: A preliminary report. In: Clutton-Brock, T. (Ed.), Primate Ecology. Academic Press, London.

5. Dunbar, R.I.M. (1977). The Gelada Baboon: Status and conservation. In: H.R.H. Prince Rainier and Bourne, G. (Eds), Primate Conservation. Academic Press, New York.

6. Dunbar, R.I.M. (1983). Theropithecines and hominids: Contrasting solutions to the same ecological problem. Journal of Human Evolution 12: 647-658.

7. Dunbar, R.I.M. (1985). The social ecology of Gelada Baboons. In: Rubenstein, D. and Wrangham, R. (Eds), Ecological Aspects of Social Evolution. Princeton University Press, Princeton.

8. Hill, W.C.O. (1970). Primates: Comparative Anatomy and Taxonomy. Vol. VIII. Cyno pithecinae. Edinburgh University Press, Edinburgh.

9. Hurni, H. (1986). Management Plan: Simen Mountains National Park and surrounding Area. Ministry of Agriculture, Natural Resourcers Conservation and Development Main Department; Wildlife Conservation Organisation; Unesco World Heritage Committee.

10. Iwamoto, I. and Dunbar, R. (1983). Thermoregulation, habitat quality and the behavioural ecology of Gelada Baboons. Journal of Animal Ecology 52: 357-366.

11. Jolly, C.J. (1972). Classification and natural history of Theropithecus (Simopithecus) (Andrews 1916): Baboons of the African Plio-Pleistocene. Bulletin of the British Museum of Natural History (Geology) 22: 1-123.

12. Jolly, C.J. and Ucko, P. (1969). The riddle of the sphinx-monkey. In: Douglas, M. and Kaberry, L. (Eds), Man in Africa. Tavistock Publications, London.

13. Kawai, M. (Ed.) (1979). Ecological and Sociological Studies of Gelada Baboons. Karger, Basel.

14. Kawai, M., Dunbar, R., Ohsawa, H. and Mori, U. (1983). Social organisation of Gelada Baboons: Social units and definitions. Primates 24: 1-13.

15. Klotzli, F. (1975). Simen - a review of its problems. Walia 6: 18-19.

16. Nievergelt, B. (1981). Ibexes in an African Environment. Springer, Berlin.

17. Olney, P.J.S. (Ed.) (1986). International Zoo Yearbook 24/25. Zoological Society of London.

18. Stähli, P. (1978). Changes in settlement and land use in Simen, Ethiopia, especially from 1954 to 1975. In: Messerli, and Aerni, (Eds), Simen Mountains - Ethiopia. Vol. 1. Geographical Institute, University of Bern.

19. Stark, D. and Frick, H. (1958). Beobachtungen an aethiopischen Primaten. Zool. Jb. (Syst.) 86: 41-70.

20. Szalay, F. and Delson, E. (1979). Evolutionary History of the Primates. Academic Press, New York.

21. Teshome Ashine (1985). In litt.

22. Watson, R., Tippett, C., Tippett, M. and Marrian, S. (1973). Aerial livestock, land-use and land potential surveys for the central highlands of Ethiopia. Mimeo report, Livestock and Meat Board, Addis Ababa.

23. Wolfheim, J.H. (1983). Primates of the World: Distribution, Abundance and Conservation. University of Washington Press, Seattle and London.

24. Yalden, D., Largen, M. and Kock, D. (1977). Catalogue of the mammals of Ethiopia. 3. Primates. Monitore Zoologico Italiano 9(1): 1-52. 


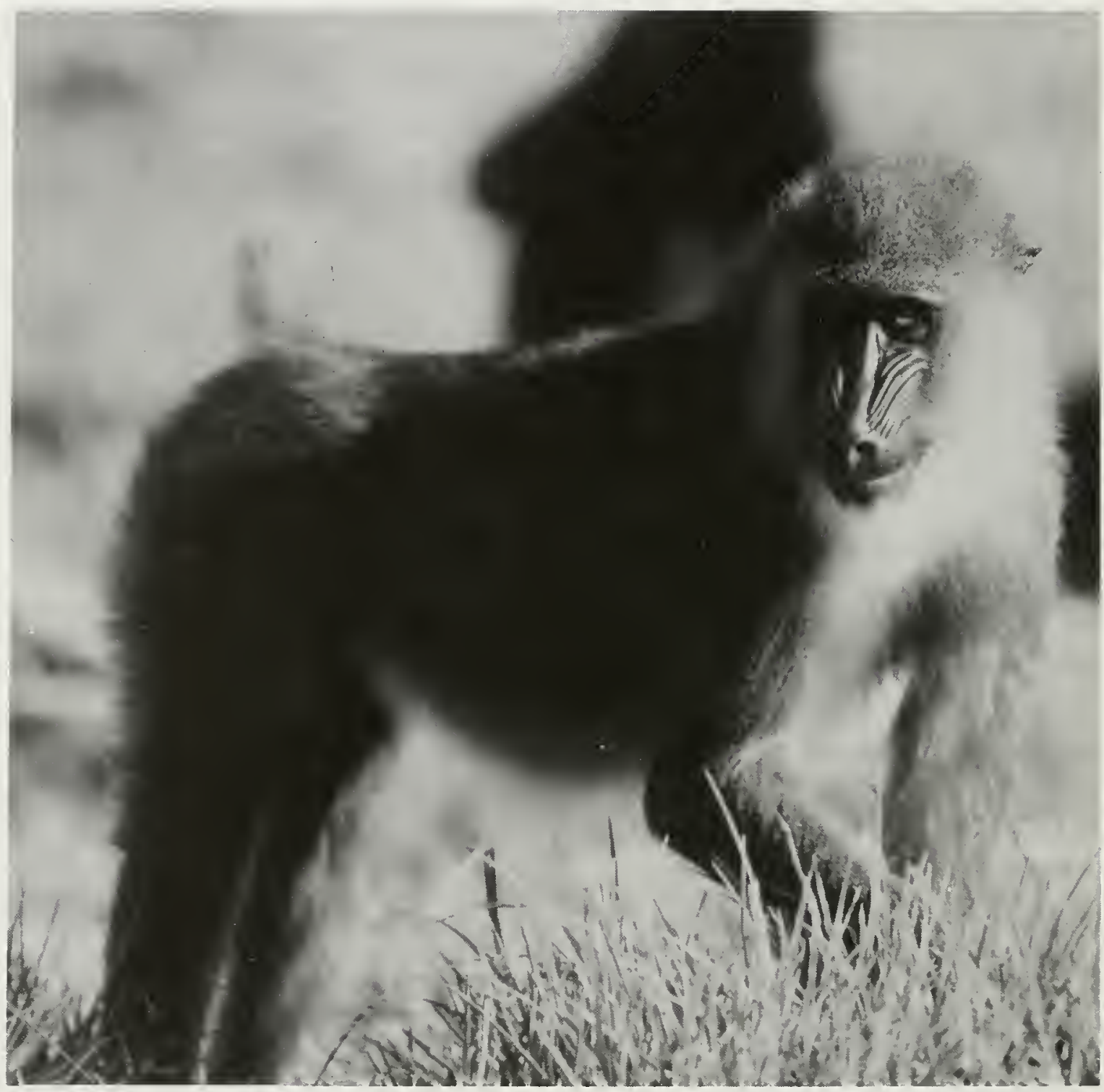

The Mandrill Mandrillus sphinx is found from south-western Cameroon to south-western Congo. A semi-terrestrial, opportunistic feeder sometimes found in large aggregations, the species is threatened by intense hunting and habitat destruction. Photo by Russell A. Mittermeier, WWF-US. 
The IUCN Red Data Book

SUMMARY Mandrills are restricted to forest areas south of the Sanaga River in south-western Cameroon, Rio Muni (Equatorial Guinea), western Gabon and south-western Congo (Brazzaville). No estimates of numbers are available, but drastic declines are thought to have occurred in recent years. Habitat destruction and hunting are the main threats to this semi-terrestrial, opportunistic feeder, and effective protection is lacking in most areas. Surveys are urgently needed to determine the location of viable populations; these habitats need practical and legal protection especially against hunting and logging. The species breeds well in captivity. It is listed in Class B of the African Convention and on Appendix 1 of CITES.

DISTRIBUTION Mandrills are restricted to the Gabon forest block, and according to Grubb (9), are separated from the Drill (M. leuco phaeus) in occurring south of the Sanaga Riger. They are found in southern Cameroon, Rio Muni (Equatorial Guinea), western Gabon, and south-western Congo (Brazzaville) $(4,8,10,20,23)$. The existence of the subspecies $M$. s. sphinx reported $(5,6)$ from Togo, southern Nigeria and Cameroon north of the Sanaga remains uriclear. The subspecies, $M$. s. insularis, is identified as endemic to the island of Bioko (Fernando Po) $(5,6)$. In Gabon, the Mandrill's (M. s. madarogaster) distribution is limited by the Ivindo and Ogooue Rivers in the east, and it is unlikely to occur east of the Dja River in Cameroon $(9,10,11)$ since it is not found as far east as the Dja Reserve. It has been exterminated locally throughout much of its range in south-western Cameroon $(15,23)$, particularly to the south of Yaounde (15). It does not occur in the forests of south-eastern Cameroon (11) or east of the Zaire River $(9,19)$. Its distribution is probably limited by savannah zones to the east and the Zaire River to the south (11).

POPULATION Total numbers are unknown but have undoubtedly declined in recent years $(8,10)$. The species is generally rare, and in some places has been locally exterminated $(8,10,23,24)$. The largest remaining populations are probably to be found in Gabon (11) and in the mid-1970s, numbers in the Wonga-Wongue National Park were thought to be "fair-sized" (3). A small population at low densities exists in the Campo Reserve in southern Cameroon $(12,13)$.

HABITAT AND ECOLOGY Mandrills are found in tropical rain forest, montane forest, thick secondary forest and thick bush $(10,13,14,15,20,23)$. They are semi-terrestrial $(23,26)$ and forage primarily at less than $5 \mathrm{~m}$ off the ground (12). Diets are diverse and include fruits, buds, leaves, roots, insects, fungus and seeds $(11,12,20,23)$. Oil palm fruits (Elaeis guineensis) are frequently eaten from local plantations $(20,23)$. When food is scarce, during and at the end of the dry season, Mandrills raid crops from farms $(20,23)$. They readily eat small vertebrates in captivity (23), and have been observed to eat them in the wild (17). Ranging patterns are poorly known; home ranges may be $30-50 \mathrm{sq} . \mathrm{km}$ (11). Mandrills are now thought to have a flexible social organization, living in single-male harem groups of $15-50$ animals $(10,11)$ that may associate with other such units to form large aggregations of 100-200 animals $(13,23)$. Their complex vocalizations may serve to maintain group cohesion and facilitate the formation of large aggregations $(13,23)$.

THREATS The major threats are habitat destruction and hunting. Mandrills are rare, living at relatively low densities (11). Throughout the species' range, it is poorly protected, and could be threatened with complete extinction should populations continue to decline under pressure from hunting and habitat disturbance (21).

Cameroon Mandrills are hunted for food (8), and much of the forest within their range has been cleared or logged $(8,15)$. 
Rio Muni (Equatorial Guinea) They are considered excellent meat, being preferred to domestic livestock by $20 \%$ of Fang people questioned (24). As a result, they have been heavily hunted and have become extremely rare (24). Dried and smoked Mandrill meat has been found for sale in some markets (23). Logging had also removed the majority of commercial tree species by 1972 (27).

Gabon Mandrills are hunted for their meat (15). A more serious threat is posed by the timber industry which, with the building of the Trans Gabonaise railway, will permit exploitation of previously inaccessible areas of primary forest (7). Logging also increases the local demand for meat by the timber workers, and many hunt, and log, illegally inside reserves and parks (7).

Congo (Brazzaville) Game meat is the most important source of protein after fish, and hunting and poaching are widespread $(25,28)$. The loss of fauna to hunting is so serious that in 1982 Verschuren thought the country would soon become a "zoological desert" (28). Much of the forest has been destroyed and replaced by fire-maintained grassland (25). Illegal logging occurs within the reserves (28). Suitable Mandrill habitat is now limited to small forest blocks in the south and west (10).

CONSERVATION MEASURES Surveys are urgently needed to determine where viable populations exist. The areas containing Mandrills need immediate protection, both legal and practical, against logging and hunting.

Cameroon Permits are required to trap or export $M$. (P.) sphinx (16). They do not occur in any current or proposed national parks, but are found in the Campo Reserve (1). The reserve has been heavily logged, and further exploitation is planned (1). Effective protection of existing reserves is essential.

Rio Muni (Equatorial Guinea) The species is unprotected (16).

Gabon Export is possible only under permit (19). Mandrills are known from Wonga-Wongué National Park, and five other reserves including the large Lopé-Okanda Reserve $(7,10)$. However, settlements, hunting and logging were taking place within many of these areas (7). Effective protection of reserves is essential (10).

Congo (Brazzaville) The range of $M$. sphinx should encompass four reserves (28), but these do not appear to have been formally gazetted and are primarily fire-maintained grassland (25) and therefore unsuitable for Mandrills. It is not known if viable populations of Mandrills are found in any of the reserves. Without outside financial support, it is unlikely that adequate enforcement of legal protection will be possible $(25,28)$.

Mandrillus (Papio) sphinx is listed in Class B of the African Convention (1969); it may be hunted, killed, captured or collected only under special authorization issued by the competent authority.

It is listed on Appendix 1 of the 1973 Convention on International Trade in Endangered Species of Wild Fauna and Flora, therefore any trade in it or its products is subject to strict regulation by ratifying nations, and trade for primarily commercial purposes is banned.

CAPTIVE BREEDING Mandrills are relatively easy to keep in captivity and breed well in many collections worldwide (22). Gestation periods are estimated to be 172-176 days (2) and 183-225 days (18).

REMARKS Both Drills and Mandrills are sometimes classified within the genus Papio. For a description see (5).

Peter Grubb and Michael Harrison kindly commented on this data sheet. 


\section{REFERENCES}

1. Agland, P.C. (1984). Pers. comm.

2. Carman, M. (1979). The gestation and rearing periods of the Mandrill Mandrillus sphinx at the London Zoo. International Zoo Yearbook 19: 159-160.

3. Curry-Lindahl, K. (1974). Conservation problems and progress in Equatorial Africa. Environmental Conservation 1(2): 111-122.

4. Dandelot, P. (1968). Preliminary Identification Manual for African Mammals. Primates, Anthro poidea. Smithsonian Institution, Washington.

5. Dandelot, P. (1974). Part 3: Order Primates. In: Meester, J. and Setzer, H.W. (Eds), (1971-77). The Mammals of Africa: An Identification Manual. Smithsonian Institution Press, Washington, D.C.

6. Dobroruka, L.J. (1966). Kleine notizen über baumpaviane, Papio leucophaeus (F. Cuvier, 1807) und Papio sphinx (Linnaeus, 1758). Rev. Zool. Biol. Afr. 73: 155-158.

7. Gandini, G. (1979). Gabon report. Unpublished report.

8. Gartlan, J.S. (1974). Pers. comm. In: Wolfheim, J.H. (1983). Primates of the World: Distribution, Abundance and Conservation. University of Washington Press, Seattle and London.

9. Grubb, P. (1973). Distribution, divergence and speciation of the Drill and Mandrill. Folia Primatologica 20: 161-177.

10. Harrison, M.J.S. (1983-84). In litt.

11. Harrison, M.J.S. (1988). The Mandrill in Gabon's rainforests: Ecology, distribution and status. Unpublished manuscript for Oryx

12. Hoshino, J. (1985). Feeding ecology of Mandrills (Mandrillus sphinx) in Campo Animal Reserve, Cameroon. Primates 26: 248-273.

13. Hoshino, J., Mori, A., Kudo, H., and Kawai, M. (1984). Preliminary report on the grouping of Mandrills (Mandrillus sphinx) in Cameroon. Primates 25: 295--307.

14. Jeannin, A. (1936). Les Mammifères Sauvages du Cameroun. Encyclo pédie Biol. No. 16. Lechevalier, Paris.

15. Jouventin, P. (1975). Observations sur la socio-ecologie du Mandrill. La Terre et la Vie 29(4): 493-532.

16. Kavanagh, M. and Bennett, E.L. (1984). A synopsis of legislation and the primate trade in habitat and user countries. In: Mack, D. and Mittermeier, R.A. (Eds), International Trade in Primates. TRAFFIC (U.S.A.).

17. Kudo, H. and Mitani, M. (1985). New record of predatory behaviour of Mandrills in Cameroon. Primates 26: 161-167.

18. Littlewood, A. and Smith, J. (1979). Breeding and hand-rearing Mandrills Mandrillus sphinx at Portland Zoo. International Zoo Yearbook 19: 161-165.

19. MacKinnon, J.R. (1977). Mountain Gorillas and Bonobos. Oryx 13(4): 372-382.

20. Malbrant, R. and MacLatchy, A. (1949). Faune de l'Equateur Africain Français. 2. Mammifères. Lechevalier, Paris.

21. Oates, J.F., Gartlan, J.S. and Struhsaker, T.T. (1982). A framework for planning rain-forest primate conservation. International Primate Society Newsletter No. 1.

22. Olney, P.J.S. (Ed.) (1986). International Zoo Yearbook 24/25. Zoological Society of London.

23. Sabater Pi, J. (1972). Contribution to the ecology of Mandrillus sphinx Linnaeus 1758 of Rio Muni (Republic of Equatorial Guinea). Folia Primatologica 17: 304-388.

24. Sabater Pi, J. and Groves, C. (1972). The importance of higher primates in the diet of the Fang of Rio Muni. Man 7: 239-243.

25. Spinage, C.A. (1980). Parks and reserves in Congo Brazzaville. Oryx 15(2): 292-295.

26. Struhsaker, T.T. (1969). Correlates of ecology and social organization among African cercopithecines. Folia Primatologica 11: 80-118.

27. Struhsaker, T.T. (1972). Rain-forest conservation in Africa. Primates 13: 103-109.

28. Verschuren, J. (1982). Republique Populaire de Congo. Relance de la conservation de la nature. Unpublished report. 


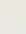


The IUCN Red Data Book

DRILL

ENDANGERED

Mandrillus leucophaeus (F. Cuvier, 1807)

Order PRIMATES

Family CERCOPITHECIDAE

SUMMARY The Drill is a highly endangered primate which now appears to be restricted to south-western Cameroon, being close to extinction in Nigeria and on Bioko (Fernando Po). No population estimates exist, but numbers have declined dramatically in recent years. The only protected population occurs within Korup National Park, Cameroon. The species is semi-terrestrial with a flexible social organization consisting of small units occasionally joining together in aggregations of up to 200 animals. Hunting and habitat destruction pose serious threats to the species' survival. Surveys are urgently needed to determine whether viable populations occur outside Korup and to provide immediate protection against hunting. The species breeds in captivity. It is listed in Class B of the African Convention and in Appendix 1 of CITES.

DISTRIBUTION The Drill occurs in the Gabon Forest block where its distribution is uncertain Three subspecies have been described. The subspecies $M$. l. poensis $(4,6)$ was knowr from Bioko $(2,7)$ and may still be present at low densities (3). M. l. leucophaeus was previously thought to occur south of the Sanaga River in southern Cameroon, Gabon and eastwards to the Zaire River $(4,6,14)$. However, its presence in Gabon (25) is still doubtful and reports await confirmation since misidentifications of young Mandrills (Mandrillus sphinx), in poorly lighted dense forest are likely (17). It is unlikely to co-occur with Mandrills due to similar ecological requirements (17). Currently, the Drill is thought to be separated from the Mandrill by the Sanaga River $(1,11,15)$ and thus occurs only from the Cross River in Nigeria south-eastwards to the Sanaga River in Cameroon (M. l. mundamensis) $(4,6)$. The Sanaga may act as a faunal boundary, but some primates are known to cross the river and this may be the case with the Drill $(13,15)$. The Drill is thought to be close to extinction in Nigeria (11) where it is now known only from isolated mountain forest patches near Afi River on the border with Cameroon (23). It is restricted to an area of 300 by $250 \mathrm{~km}$ in Cameroon $(1,11)$.

POPULATION No estimates exist. Numbers have undoubtedly declined throughout its restricted range in recent years and the species is thought to be threatened with complete extinction $(19,24)$. It was abundant in Korup National Park in 1972 (23), and this is the only protected area known to contain significant populations $(11,12)$. Other reserves, such as the Southern Bakundu Reserve, no longer support significant populations (11).

HABITAT AND ECOLOGY Drills are found in lowland rain forest, coastal, and riverine forest $(8,11,22)$. They occur in mature secondary forest, only infrequently in young secondary forest (13), and never in open country away from forests (9). Diet is not well known, but fruits and invertebrates are taken $(13,22)$. They are semi-terrestrial $(13,22)$ and group sizes are extremely variable ranging from 14 to close to $200(8,22)$. Groups appear to be composed of single-male units of about 20 animals, which frequently join other such units (8). Solitary males are also observed $(8,22)$. Coalescence of small units is accompanied by loud "crowing" calls $(8,22)$. Groups appear to range in a fairly restricted area (8).

THREATS Habitat destruction and hunting within its very limited distribution are the major threats. Extensive selective logging and forest clearance have taken place throughout its range in Cameroon. Reafforestation has involved the planting of non-palatable exotic species such as Eucalyptus and Gemlina arborea (10). Logging roads open areas to cultivators, causing further habitat loss, and allowing increased access by hunters (10).

Drills are shot as crop pests and hunted extensively for their meat which is preferred for its sweet flavour (9). The animals are particularly vulnerable to hunters since large aggregations are easily located by their loud vocalizations, and once found can be forced into trees by hunter's dogs. Twenty or more animals can be shot in a single encounter (10). The level of hunting in 1975 was so high that it was seriously threatening the Drill's chances of survival (10). 
CONSERVATION MEASURES Detailed surveys are urgently required to determine if viable populations remain in Nigeria, on Bioko, or in Cameroon outside of Korup. Any area containing adequate populations should be immediately protected, and all populations should be rigorously protected against hunting.

Recent observations of Drills in the forests of the Mbe Mountains and on the Obudu Cattle Ranch, Nigeria (16) suggest that effective protection of the forest reserves in this area (Afi River and Boshi-Okwangwo) are a high priority for the conservation of Drills. Proposals to restrict hunting of primates and reduce logging pressures (16) need to be implemented.

The status, and effective protection, afforded to Korup National Park needs monitoring. The development of the park is being financed by grants from the British Overseas Development Agency and World Wildlife Fund (U.K.). An extensive conservation education programme in the vicinity of the park was being conducted from 1981-1983 (21). Permits are required to trap or export Drills in Cameroon (18); this law needs to be enforced.

Mandrillus (Papio) leuco phaeus is listed in Class B of the African Convention (1969); it may be hunted, captured, killed or collected only under authorization issued by the competent authority.

It is listed on Appendix 1 of the 1973 convention on International Trade in Endangered Species of Wild Fauna and Flora and therefore any trade in it or its products is subject to strict regulation by ratifying nations, and trade for primarily commercial purposes is banned.

CAPTIVE BREEDING Drills have been bred for at least two generations in several collections around the world (16). Approximately 60 individuals were kept in zoos in 1985, many of them housed in pairs or as solitary animals. Reproductive success under such conditions has been low; only $25 \%$ of captive animals breed and only 2-4 young are produced each year (5). A successful breeding programme is underway at the Hannover Zoo, with four females who give birth regularly. A studbook for the Drill is maintained at Hannover Zoo by Dr Michael Boer (Address: Zoologischer Garten Hannover, D-3000 Hannover, Adenaueralle 3, West Germany) (16).

REMARKS Drills and Mandrills are often included in the genus Papio. Drills exhibit high levels of sexual dimorphism in canine and body size with males twice the size of females $(4,22)$. For a description see (4).

Peter Grubb and Michael Harrison kindly commented on this data sheet.

\section{REFERENCES}

1. Agland, P.C. (1984). Pers. comm.

2. Basilio, A. (1962). La Vida Animal en la Guinea Espanola. Inst. Estudios Africanos, Madrid.

3. Butynski, T.H. (1986). Pers. comm. to J.F. Oates.

4. Dandelot, P. (1974). Part 3: Order Primates. In: Meester, J. and Setzer, H.W. (Eds), (1971-77). The Mammals of Africa: An Identification Manual. Smithsonian Institution Press, Washington, D.C.

5. Dittrich, L. (1985). In litt. to Dr P J Olney.

6. Dobroruka, L.J. (1966). Kleine notizen über baumpaviane, Papio leucophaeus (F. Cuvier, 1807) und Pa pio sphinx (Linnaeus, 1758). Rev. Zool. Biol. Afr. 73: 155-158.

7. Eisentraut, M. (1973). Die Wirbeltierfauna von Fernando Poo und West Kamerun. Bonn. Zool. Monog. 3: 1-428.

8. Gartlan, J.S. (1970). Preliminary notes on the ecology and behavior of the Drill. In: Napier, J.R. and Napier, P.H. (Eds), Old World Monkeys. Academic Press, New York.

9. Gartlan, J.S. (1974). Pers. comm. In: Wolfheim, J.H. (1983). Primates of the World: Distribution, Abundance and Conservation. University of Washington Press, Seattle and London.

10. Gartlan, J.S. (1975). The African coastal rain forest and its primates - threatened resources. In: Bermant, G. and Lindburg, D.G. (Eds), Primate Utilization and Conservation. John Wiley and Sons, New York. 
11. Gartlan, J.S. (1977). In litt.

12. Gartlan, J.S. and Agland, P.C. (1980). A proposal for a program of rain-forest conservation and national park development in Cameroon, West-Central Africa. Unpublished report to the Gulf Oil Corporation.

13. Gartlan, J.S. and Struhsaker, T.T. (1972). Polyspecific associations and niche separation of rain-forest anthropoids in Cameroon. West Africa. Journal of Zoology 168: 221-266.

14. Grubb, P. (1973). Distribution, divergence and speciation of the Drill and Mandrill. Folia Primatologica 20: 161-177.

15. Grubb, P. (1984). In litt.

16. Harcourt, A.H., Stewart, K.J. and Inaharo, I.H. (1988). Nigeria's Gorillas: A survey and recommendations. Unpublished report to the Nigerian Conservation Foundation.

17. Harrison, M.J.S. (1988). The Mandrills of Gabon's rainforest: Ecology, distribution and status. Unpublished manuscript for Oryx.

18. Kavanagh, M. and Bennett, E.L. (1984). A synopsis of legislation and the primate trade in habitat and user countries. In: Mack, D. and Mittermeier, R.A. (Eds), International Trade in Primates. TRAFFIC (U.S.A.).

19. Oates, J.F., Gartlan, J.S. and Struhsaker, T.T. (1982). A framework for planning rain-forest primate conservation. International Primate Society Newsletter No. 1.

20. Olney, P.J.S. (Ed.) (1986). International Zoo Yearbook 24/25. Zoological Society of London.

21. Parrot, J. (1981). Cameroon forest parks conservation education programme, report 1980/81. Unpublished report.

22. Struhsaker, T.T. (1969). Correlates of ecology and social organization among African cercopithecines. Folia Primatologica 11: 80-118.

23. Struhsaker, T.T. (1972). Rain-forest conservation in Africa. Primates 13: 103-109.

24. Struhsaker, T.T. (1974). Pers. comm. In: Wolfheim, J.H. (1983). Primates of the World: Distribution, Abundance and Conservation. University of Washington Press, Seattle and London.

25. Tutin, C.E.G. and Fernandez, H. (1987). Gabon: A fragile sanctuary. Primate Conservation 8: 160-161. 

SUMMARY The Diana Monkey inhabits high canopy rain forest in Sierra Leone, Liberia, Côte d'Ivoire, Ghana and Guinea. Early reports of its occurrence in other areas are unconfirmed. No population estimates are available and reports of its rarity vary widely, although it is almost certainly threatened throughout much of its range as a result of habitat destruction and hunting. In all countries where it occurs it needs protection from hunting and the preservation of remaining areas of habitat. Further studies and local conservation education programmes are also urgently required. The species breeds well in captivity. It is listed in Class B of the African Convention and on Appendix 1 of CITES.

DISTRIBUTION The Diana Monkey occurs in southern Sierra Leone, Liberia, southern Côte d'Ivoire, western and southern Ghana $(10,42)$, and the Seredou area of south-west Guinea (31). Two subspecies are recognised: $C$. $d$. diana is found to the west of the Sassandra River, and $C$. $d$. roloway to the east (10). Western and northern limits of the species are about $12^{\circ} \mathrm{W}$ and $8^{\circ} 20^{\prime}$ E respectively (42), roughly coincident with the limits of the Guinea high forest. The species occurs only west of the Volta River $(4,5)$, and its north-east limit is probably the Afram River, a tributary of the Volta (14). Reports of its presence as far north-west as $13^{\circ} \mathrm{N}, 17^{\circ} \mathrm{W}$, in the Gambia (35) and as far east as Cameroon and Zaire have never been confirmed and are based on limited material (1 or 2 skins) whose origin and interpretation are highly questionable $(41,42)$. The former report seems particularly unlikely as it would involve the species living outside its usual habitat.

POPULATION Total numbers are unknown but have almost certainly declined rapidly during this century throughout the range (42). Its current status is poorly known. In 1974 the species was considered by Struhsaker to be "one of the most threatened in Africa" (33). In Sierra Leone, the species is found in the high forest zone in the south-east of the country, in the Freetown peninsula and in the Gola Forest Reserves (11). They are abundant only in those areas of Gola where primary forest is intact, and where hunting pressures are light (11). Populations appear to be fragmented by forest loss and only locally abundant $(25,39)$. Densities on the 12 sq.km Tiwai Island in the Gola Forest Area are high; 30-50 animals per sq. km (41). Where logging is combined with a high hunting pressure in the Gola Forests, the species is absent (11). No information is available on population sizes in Guinea and surveys of high forest areas are needed. It was previously considered common in the Mount Nimba area in Liberia, but has become rare (6). Its status elsewhere in the country is unknown. Population sizes have declined for most primates due to hunting and logging in Liberia (40). The species is rare throughout Côte d'Ivoire (34), but it was common in the Tai Forest in the early 1970s (9,23). In Ghana, all primates had been exterminated locally throughout much of the country by 1976 (4); Diana Monkeys are still found in the region of the Bia tributaries $(13,15)$ but their density appears to be low: 12 animals per sq. $\mathrm{km}(9)$.

HABITAT AND ECOLOGY Diana Monkeys inhabit high canopy forests, and are also found in mature secondary forest, riverine forest $(4,5,13,15,24)$, and areas of semi-deciduous forest (41). Although they are regarded as a crop-pest in some areas $(15,38)$ none have been observed to enter cultivated areas or to raid crops $(15,17,28,33,41)$. Diurnal and arboreal, Diana Monkeys are often sighted in the upper layers of the canopy $(5,24)$ but also forage in the dense understory (9). They are frequently observed associating with other species, such as Black-and-White Colobus Monkeys $(9,19,23,24)$. Group size is variable, ranging from $15-40(9,41)$. Typically groups are composed of one adult male with 6-8 adult females and their immature offspring $(9,41)$. Diets are poorly known, but in Bia in Ghana, the primary foods were fruits, arthropods, and oil-rich seeds $(7,9)$. Groups appear to be territorial (41) and defend large home ranges of 189 ha (7). 
THREATS Hunting and habitat destruction, especially in combination, are the primary threats throughout its relatively restricted range. $C$. diana can be found in lightly logged areas, but is absent when the canopy area is reduced, due to its dependence on upper layers of the forest $(11,41)$. They are also highly susceptible to hunting since they are conspicuous both in colour and vocalize frequently as they travel in the high canopy. They are desired prey due to their relatively large body size.

Large-scale deforestation by logging has resulted in vast reductions in forest cover throughout the habitats of $C$. diana in Sierra Leone $(2,37,38)$, Liberia (40) and Ghana $(4,12,13)$. In Sierra Leone, only $3 \%$ of the mature forest remains, and much of that is under logging concessions or is being cut $(2,25,38)$. Replanting with unpalatable species such as Eucalyptus reduces primate habitats even further (38). In Ghana, charcoal production, shifting agriculture and cocoa plantations continue to erode areas of forest, even within some reserves $(13,21)$. In Bia, a significant proportion of the diet of $C$. diana is derived from commercially important tree species (9), suggesting that even moderate levels of logging will decrease the density of the species in many areas.

Hunting pressures are considerable throughout the region. Between 1947 and 1962, about 250000 primates were killed in government pest control programmes in Sierra Leone $(20,24,36,38)$, driving populations to near extinction in the south-east. Many $C$. diana were undoubtedly killed, even though they are not crop pests $(24,38)$. While some Diana Monkeys are hunted by local residents of Sierra Leone, many more primates are killed by Liberian commercial hunters operating within the country and exporting the meat $(24,38)$. Tens of thousands of primate carcasses were exported by truck each year from Sierra Leone to Liberia $(24,38)$. High forest species such as $C$. diana seem to be taken preferentially $(24)$. In 1983, the Ministry of Agriculture and Forestry of Sierra Leone issued a directive that Liberian hunters should not be permitted to enter the country, and that licenses already granted should be withdrawn. This has led to a decrease in hunting in Sierra Leone (25), but its effect on primate populations needs to be monitored. In Liberia game meat is the primary source of protein, and primates in the country continue to be hunted on a very large scale $(15,16,29,40)$. Hunting is almost totally uncontrolled in Liberia and has led to extinctions of all wildlife in some regions $(30,40)$. In Ghana as well, primates including $C$. diana are intensively hunted for meat $(4,13,21,22)$, again resulting in local extinctions (4). C. diana is hunted for both its meat and its skin in Côte d'Ivoire (34), but no recent information on the effects of hunting on primate populations is available. Hunting pressure is obviously a major contributing factor in the decline of primate populations in the region. The combined effects of hunting and logging tend to make the situation even worse. Logging activities open new, previously inaccessible areas of forest to hunters when access roads are built (40). Demands for meat among logging and subsidiary workers increase in the area. Agriculturalists can also take advantage of recently cleared areas (40). And, the removal of commercial timber species, even when selective, reduces the canopy cover which provides protection, travel routes and food for primates. $C$. diana appears to be particularly susceptible to the combined pressures of hunting and logging, while it can survive in areas of light selective logging (11).

CONSERVATION MEASURES The hunting of $C$. diana needs to be totally banned or severely restricted, both legally and practically, in all countries within its range. Remaining areas of habitat require protection and integrated management of forests needs to be established. Conservation education is essential to alter attitudes so that primates are not perceived as crop-pests or abundant meat species. Further studies on the distribution and status of $C$. diana are also necessary.

Sierra Leone The survival of $C$. diana can best be assured by protecting it within the Gola Forest Reserves $(24,28,37,38)$. These reserves have been identified as areas suitable for protected status, and a management plan integrating protected areas with carefully controlled selective logging, and complete protection from hunting has been initiated $(7,25,38)$. Tiwai Island has been approved as a protected area for primates $(7,41)$. The export of all wildlife and wildlife products was banned in $1982(39)$. The effectiveness of this regulation needs to be monitored. The Sierra Leone Environment and Nature Conservation Association was conducting a media campaign to influence local attitudes in favour of protecting the Gola Forest $(2,38)$, but further 
educational campaigns to alter perceptions of primates as abundant crop-pests need to be initiated. The new Conservation Society is helping to develop a national conservation strategy (25).

Liberia Seven areas were proposed as reserves $(30,40)$, and a 1085 sq. km area of intact rain forest, Sapo National Park, was gazetted in 1984 (30). C. diana are found in the new park (3). The need for strict regulation of hunting within Liberia has been stressed $(30,40)$ in combination with a widespread conservation education programme (30). New hunting regulations were established in 1982 (29). Primate exports are illegal (18). The effectiveness of these laws needs to be assessed.

Ghana C. diana is found in Bia National Park, which was gazetted in 1974 (15). The development of alternative sources of protein to hunted meat is a priority for the area (13), as is the development of tourism in high forest national parks to provide a financial base $(4,13)$. Schemes for developing conservation education programmes within protected areas have been proposed (13). C. diana is protected by law from hunting, trapping or export in Ghana (18). Hunting, shooting, trapping or snaring animals within forest reserves is illegal (1); these laws need to be practically enforced.

Guinea No information is available on the protected status of Diana Monkeys.

Côte d'Ivoire The hunting, capture and export of all wild animals is illegal, apar form exceptional cases when special licenses may be granted (18); these laws need to be enforced. C. diana is found in the Tai Forest National Park (23).

The species is included in Class B of the African Convention (1969); it may be hunted, captured, killed or collected only under authorization issued by the competent authority.

Listed in Appendix 1 of the 1973 Convention on International Trade in Endangered Species of Wild Fauna and Flora (CITES), and therefore any trade in it or its products is subject to strict regulation by ratifying nations, and trade for primarily commercial purposes is banned.

CAPTIVE BREEDING $C$. diana has been captive-bred in many zoological collections $(14,27)$.

REMARKS For description, see (14).

\section{REFERENCES}

1. Anon. (1974). Oryx 12(5): 413.

2. Anon. (1983). Sierra Leone's last forests in serious danger. Oryx 17(4): 164-165.

3. Anon. (1984). Sapo National Park in West Africa: Liberia's first national park. American Journal of Primatology 6: 74-75.

4. Asibey, E.O.A. (1978). Primate conservation in Ghana. In: Chivers, D.J. and Lane-Petter, W. (Eds), Recent Advances in Primatology, Volume 2, Conservation. Academic Press, London.

5. Booth, A.H. (1956). The Cercopithecidae of the Gold and Ivory Coasts: Geographic and systematic observations. Ann. Mag. Nat. Hist. 9(12): 476-480.

6. Coe, M. (1975). Mammalian ecological studies on Mount Nimba, Liberia. Mammalia 39(4): 523-587.

7. Cords, M. (1987). Forest guenons and Patas monkeys: Male-male competition in one-male groups. In: Smuts, B.B., Cheney, D.L., Seyfarth, R.M., Wrangham, R.W. and Struhsaker, T.T. (Eds), Primate Societies. University of Chicago Press, Chicago.

8. Curtin, P. and Curtin, S.H. (1978). Pers. comm. In: Wolfheim, J.H. (1983). Loc. cit.

9. Curtin, P. and Curtin, S.H. In litt.

10. Dandelot, P. (1974). The order Primates. In: Meester, J. and Setzer, H.W. (Eds), (1977). The Mammals of Africa: An Identification Manual. Smithsonian Institution Press, Washington, D.C.

11. Davies, A.G. (1987). The Gola Forest Reserves, Sierra Leone. Wildlife Conservation and Forest Management. IUCN, Gland and Cambridge. 
12. Foggie, A. and Hinds, J.H. (1951). In: Management and Conservation of Vegetation in Africa. Bulletin No.41 of the Commonwealth Bureau of Pastures and Field Crops. Penglais Aberystwyth, Wales.

13. Gartlan, J.S. (1981). The forests and primates of Ghana. Prospects for protection and proposals for assistance. Unpublished report.

14. Hill, W.C.O. (1966). Primates, Comparative Anatomy and Taxonomy, Vol. VI. Edinburgh University Press, Edinburgh.

15. Jeffrey, S.M. (1975). Ghana's new forest national park. Oryx 13(1): 34-36.

16. Jeffrey, S.M. (1977). How Liberia uses wildlife. Oryx 14(2): 168-173.

17. Jones, T.S. (1950). Notes on the monkeys of Sierra Leone. Oryx 11: 117-122.

18. Kavanagh, M. and Bennett, E.L. (1984). A synopsis of legislation and the primate trade in habitat and user countries. In: Mack, D. and Mittermeier, R.A. (Eds), International Trade in Primates. TRAFFIC (U.S.A.).

19. Laidler, K. (1982). Children of the gods. Animal Kingdom 85(5): 12-17

20. Mackenzie, A.F. (1952). Proceedings of the Zoological Society of London 122: 541.

21. Martin, C. (1976). Report of Project 1251. WWF Progress Re port No. 102. August 1976.

22. Mertz, A. (1981). In litt.

23. Monfort, A. and Monfort, N. (1973). Quelques observations sur les grands mammifères du Parc National de Tai (Côte d'Ivoire). La Terre et la Vie 27(4): 499-506

24. Oates, J.F. (1980). Report on a pilot study of Colobus verus and other forest monkeys in southern Sierra Leone with comments on conservation problems. Unpublished report.

25. Oates, J.F. (1983-88). In litt.

26. Oates, J.F., Gartlan, J.S. and Struhsaker, T.T. (1982). A framework for planning rain-forest primate conservation. International Primate Society Newsletter No. 1.

27. Olney, P.J.S. (Ed.). (1986). International Zoo Yearbook 24/25. Zoological Society of London.

28. Phillipson, J.R. (1978). Wildlife conservation and management in Sierra Leone. Special report to the Ministry of Agriculture and Forestry, Freetown.

29. Roben, P. (1982). In litt.

30. Robinson, P.T. and Peal, A. (1981). Liberia's wildlife - the time for decision. ZooNooz 54(10): 7-21.

31. Roche, J. (1971). Recherches mammalogiques en Guinée forestière. Bull. du Mus. Nat. d'Histoire Naturelle Ser. 3 (16): 737.

32. Roure, G. (1963). Conservation in the Ivory Coast. IUCN Publication New Series 2: 309-310.

33. Struhsaker, T.T. (1974). Pers. comm. In: Wolfheim, J.H. (1983). Loc. cit.

34. Tahiri-Zagrët, C. (1976). Le Cercopithecidae de Côte d'Ivoire Bull. Inst. Fondam. Afr. Noire 38(1): 206-230

35. Tappen, N.C. (1960). Problems of distribution and adaptation of the African Monkeys. Current Anthropology 1: 91-120.

36. Tappen, N.C. (1964). Primate studies in Sierra Leone. Current Anthropology 5(4): 339-340.

37. Teleki, G. and Baldwin, L. (1981). Sierra Leone's wildlife legacy: Options for survival. ZooNooz 54(10): 21-27.

38. Teleki, G. (1980). Hunting and trapping wildlife in Sierra Leone: Aspects of exploitation and exportation. Unpublished report.

39. Teleki, G. (1982). Pers. comm. In: Kavanagh, M. and Bennett, E.L. (1984). Loc. cit.

40. Verschuren, J. (1983). Conservation of tropical rainforest in Liberia. Report of IUCN to the Government of Liberia.

41. Whitesides, G.H. (1985) In litt.

42. Wolfheim, J.H. (1983). Primates of the World: Distribution, Abundance, and Conservation. University of Washington Press, Seattle and London. 
SUMMARY The Salongo Guenon is endemic to the Wamba Forest in Zaire where it has only recently been observed in the wild. It is relatively terrestrial, inhabiting thickets in secondary forest. Although the population density is low, it may not be rare within its restricted range. It is known to be hunted for meat. Further information is needed on its geographical distribution and population sizes. None are known to be held in captivity. It is listed in Class B of the African Convention and in Appendix 2 of CITES.

DISTRIBUTION A recently described species, thus far known only from the Wamba Forest, Zone de Djolu, Zaire ( $\left.0^{\circ} 10^{\prime} \mathrm{N}, 23^{\circ} 30^{\prime} \mathrm{E}\right)(1,2)$.

POPULATION Unknown. The population density in those areas of the Wamba forest where it has been observed are low, but it may not be a rare species within the forest (2).

HABITAT AND ECOLOGY The primary habitat of the species is thought to be thickets in secondary forest, and it may occasionally exploit swamp forest (2). It is one of the smallest cercopithecines $(1,2)$, and its small body size may be an adaptation to moving through dense vegetation (2). Observed troop sizes range from 2-15 individuals of both sexes, multi-male troops of up to 30 are reported, and solitary animals have been seen (2). They occasionally mix with other Guenons in polyspecific associations (2).

THREATS The species is hunted by residents of the forest and is very elusive as a result (2). Until further information is available on population sizes and distributions, the threat posed by hunting cannot be assessed. However, if the Guenon is an endemic species, restricted to a small forest area with low population densities, then hunting could have a considerable impact on its prospects for survival.

CONSERVATION MEASURES Further studies of distribution and conservation status are required before adequate measures can be proposed. If it is not found to live within any existing protected area then one should be established. The known populations are currently under observation by members of the Japanese Pygmy Chimpanzee (Pan paniscus) Research Project (2) in Wamba, which is a potential conservation area for many primate species.

All Guenons are included in Class B of the African Convention (1969); they may be hunted, killed, captured or collected only under special authorization granted by the compeistent authority.

The species is listed on Appendix 2 of the 1973 Convention on International Trade in Endangered Species of Wild Fauna and Flora, trade in it between acceding nations is therefore subject to regulation and monitoring of its effects.

CAPTIVE BREEDING None are known to be held in captivity.

REMARKS Originally described from a single incomplete skin (1); a more complete description, including photographs and observations in the wild has clarified its status as a separate species (2). However, further information on its taxonomic affinities is needed.

Peter Grubb and Colin Groves very kindly commented on the draft data sheet of this species. 


\section{REFERENCES}

1. Thys van den Audenaerde, D.F.E. (1977). Description of a new monkey-skin from East Central Zaire as a probably new monkey-species (Mammalia, Cercopithecidae). Rev. Zool. Afr. 91: 1000-1010.

2. Kuroda, S., Kano, T., and Muhindo, K. (1985). Further information on the new monkey species Cerco pithecus salongo Thys van den Audenaerde, 1977. Primates 26(3): 325-333. 



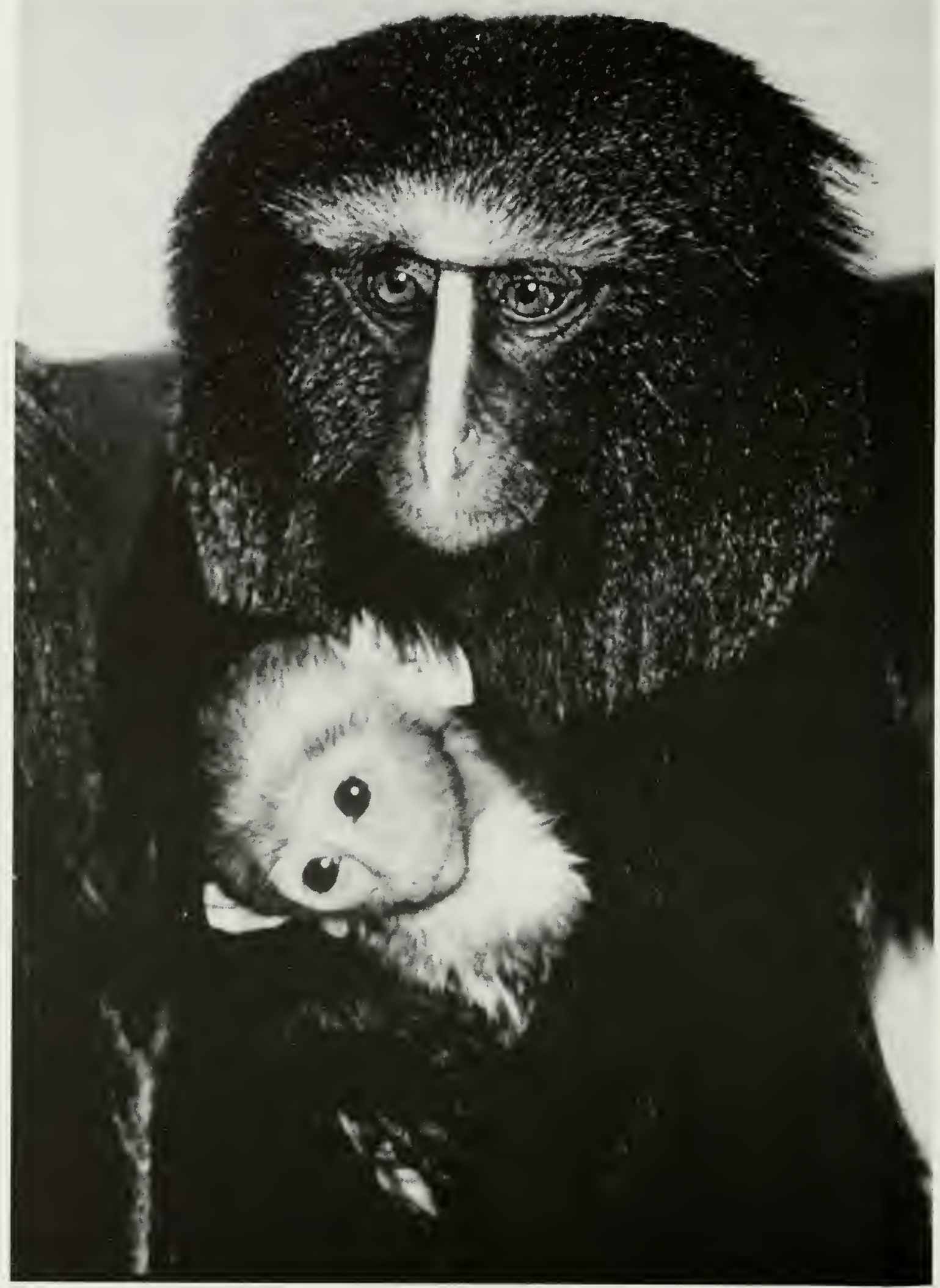

The Owl-faced Guenon Cercopithecus hamlyni is found primarily in eastern Zaire and is threatened by widespread deforestation.

Photo by C. Thouvenin. 
The IUCN Red Data Book

VULNERABLE

Cercopithecus hamlyni Pocock, 1907

SUMMARY The Owl-faced Guenon occurs principally in eastern Zaire, with a small range extension into extreme south-western Uganda and possibly Rwanda. Its habitat of lowland, montane and bamboo forests is being extensively deforested. No information is available on its occurrence within protected areas. Surveys of its status and distribution are urgently needed, as is full protection of remaining areas of habitat. The species breeds well in captivity. It is listed on Class B of the African Convention and on Appendix 2 of CITES.

DISTRIBUTION Occurs in east-central Zaire in the Ituri and Kivu districts $(1,6)$ and in extreme south-western Uganda, possibly extending into north-western Rwanda $(1,6,9,10)$. The approximate range is from $26^{\circ}-29^{\circ} \mathrm{E}$ and $2^{\circ}-4^{\circ} \mathrm{S}(11)$ and appears to be bounded by the Lukuga River to the south and the Zaire River to the west, but it is not known whether the Ituri-Epulu River is the northern limit (10). By 1960, and probably for several hundred years previously, the species was divided by a belt of savannah into lowland and highland populations (10).

POPULATION No population estimates exist. Since the species is nowhere abundant or well protected, it is considered vulnerable to extinction (7).

HABITAT AND ECOLOGY C. hamlyni inhabits lowland, montane and bamboo forests up to $4600 \mathrm{~m}$ in elevation $(10,11,14)$. It is diurnal and reported to live in small groups of less than ten individuals, frequently descending to the ground (10). No other information on ecology is available.

THREATS Widespread deforestation in lower elevation forests is the major threat. In the Kivu and Ituri regions of Zaire, most of the forest between 1200 and $2200 \mathrm{~m}$ was destroyed by 1975 (13). Wildlife in the area is non-existent and human populations are dense (13).

CONSERVATION MEASURES Surveys of its status and distribution are urgently needed. Immediate full protection should be granted to remaining areas of habitat. It is not known to occur within any protected areas in the nations within its suspected range. No legal controls on export exist in Zaire (4), and hunting of primates is uncontrolled.

Included in Class B of the African Convention (1969); it may be hunted, killed, captured or collected only under special authorization granted by the competent authority.

Listed in Appendix 2 of the 1973 Convention on International Trade in Endangered Species of Wild Fauna and Flora, trade in it between acceding nations being therefore subject to regulation and monitoring of its effects.

CAPTIVE BREEDING The first captive breeding record dates from 1959 in Rotterdam Zoo, since when it has been captive-bred in many collections. Nine zoological institutions world-wide reported a total holding of 42 animals in captivity for $1980 ; 23$ were captive-bred (8).

REMARKS For description see (2). In 1928, Schwarz (12) stated that $C$. hamlyni was probably a subspecies of $C$. lhoesti, but since the two taxa are sympatric, they are now almost invariably regarded as separate species $(3,5,10)$. Lowland and highland forms of $C$. hamlyni are somewhat different, and Rahm (10) suggested that they might be different subspecies.

\section{REFERENCES}

1. Dandelot, P. (1974). Part 3: Order Primates. In: Meester, J. and Setzer, H.W. (Eds), (1971). The Mammals of Africa: An Identification Manual. Smithsonian Institution Press, Washington D.C. 
2. Hill, W.C.O. (1966). Primates, Comparative Anatomy and Taxonomy, Volume VI. Edinburgh University Press, Edinburgh.

3. Kavanagh, M. (1983). A Complete Guide to Monkeys, Apes and other Primates. Jonathan Cape, London.

4. Kavanagh, M. and Bennett, E.L. (1984). A synopsis of legislation and the primate trade in habitat and user countries. In: Mack, D. and Mittermeier, R.A.(Eds), International Trade in Primates. TRAFFIC (U.S.A.).

5. Napier, J.R. and Napier, P.H. (1967). A Handbook of Living Primates. Academic Press, London.

6. Nowak, R.M. and Paradiso, J.L. (1983). Walker's Mammals of the World. The Johns Hopkins University Press, Baltimore and London.

7. Oates, J.F., Gartlan, J.S. and Struhsaker, T.T. (1982). A framework for planning rain-forest conservation. International Primate Society Newsletter No. 1.

8. Olney, P.J.S. (Ed.) (1982). International Zoo Yearbook 22. Zoological Society of London.

9. Rahm, U.H. (1965). Distribution et écologie de quelques mammifères de l'est du Congo. Zoologica Africana 1: 149-166.

10. Rahm, U.H. (1970). Ecology, zoogeography and systematics of some African forest monkeys. In: Napier, J.R. and Napier, J.H. (Eds), Old World Monkeys: Evolution, Systematics and Behavior. Academic Press, New York.

11. Rahm, U.H. and Christiaensen, A.R. (1963). Les mammifères de la règion occidentale du Lac Kivu. Ann. Mus. Roy. Cent., Tervuren, Sci. Zool. 41: 215-220.

12. Schwarz (1928). (Cited in Rahm, 1970).

13. Verschuren, J. (1975). Wildlife in Zaire. Oryx 13(1): 25-33.

14. Wolfheim, J.H. (1983). Primates of the World: Distribution, Abundance, and Conservation. University of Washington Press, Seattle and London. 



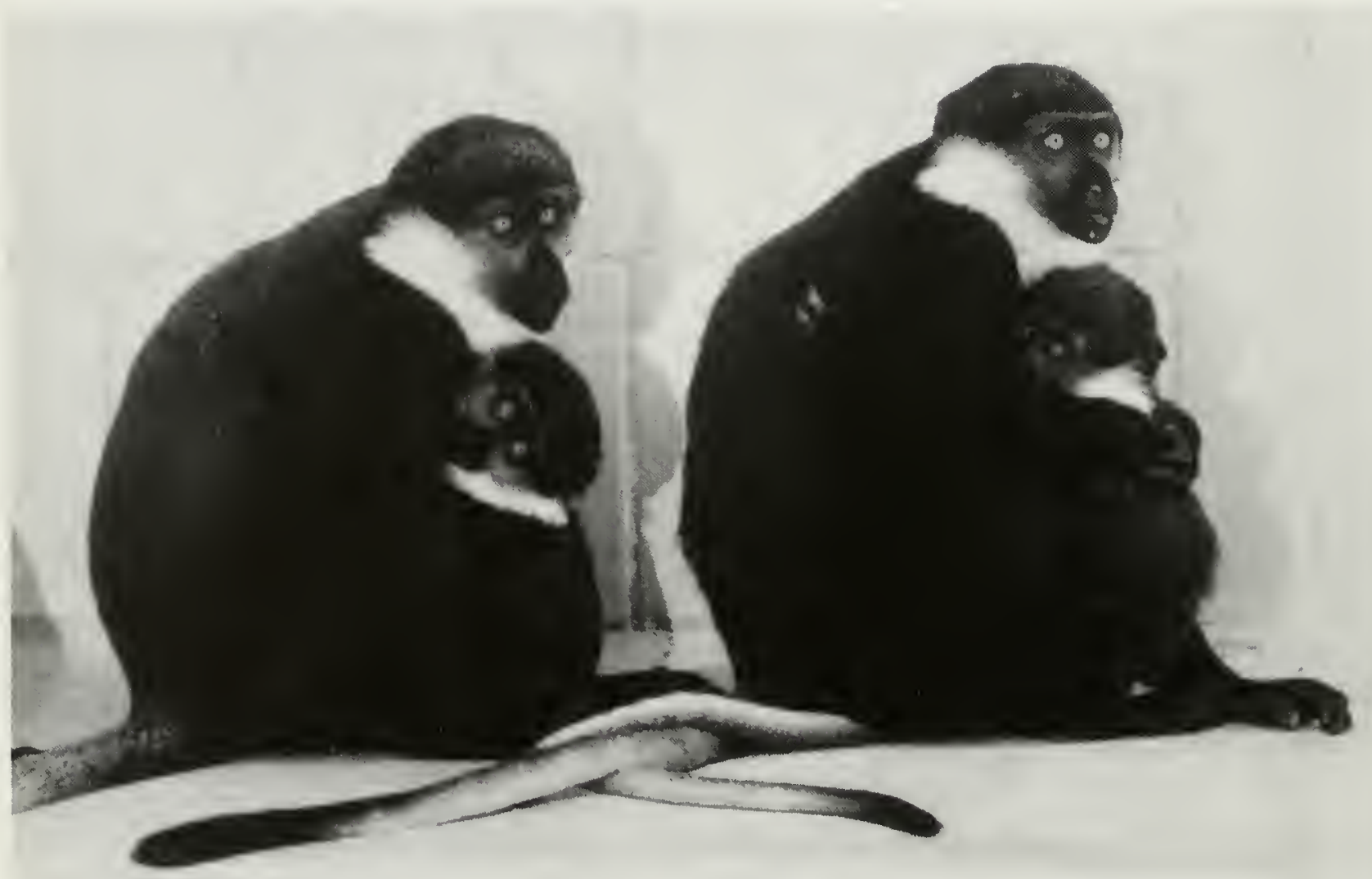

L'Hoest's Guenon Cercopithecus lhoesti is a frugivorous species dependent on undisturbed, dense montane forests. Found in the border regions of Zaire, Uganda and Rwanda, it is threatened by widespread deforestation and habitat disturbance.

Photo by Russell A. Mittermeier, WWF-US. 
The IUCN Red Data Book

SUMMARY L'Hoest's Guenon inhabits montane forests in the border regions between Zaire, Uganda, Rwanda and Burundi. Total numbers are unknown. A fruit eater, dependent on undisturbed thick forest, habitat destruction and hunting are threats within its relatively small range. While no specific measures exist to protect the species, it occurs in reserves in Uganda and Rwanda. Surveys of its status and distribution are needed, as is full protection of remaining areas of habitat and the enforcement of anti-poaching laws. A small number are held and have bred in captivity. It is listed in Class B of the African Convention and in Appendix 2 of CITES.

DISTRIBUTION C. lhoesti occurs in the border regions between Zaire, Uganda, Rwanda and Burundi $(5,14,33)$. In Zaire, it is found only in the extreme east in Uele and Kivu Districts (5); the approximate distribution is thought to be from just north of the Ituri River $\left(2^{\circ} \mathrm{N}\right)$ to just south of the Ulindi River $\left(2^{\circ} 30^{\prime} \mathrm{S}\right)(23)$, although it was previously thought to extend to $4^{\circ} \mathrm{S}$ (11). In Uganda, it occurs in the south-west of the Kigezi District (5) and in the Ruwenzori Mountains; it is found in the Budongo, Bwindi and Kibale Forests $(1,7)$. It is limited to the west of both Burundi and Rwanda (23). For map see (33).

POPULATION Total numbers are unknown. The only information on population densities is from Uganda: in one area of Kibale Forest it is found at high densities of 50 animals per sq. km but it is rare or absent from many other parts and is generally uncommon in the forest (29). It is reported to be one of the rarest cercopithecines in Bwindi Forest (1). There are no estimates of numbers or densities in other parts of its range. It is probably more abundant in montane forest than in lowland areas $(14,27)$.

HABITAT AND ECOLOGY C. lhoesti inhabits montane forest, mature lowland rain forest, gallery forest, wooded mountain slopes, and enters cultivated land to raid crops $(7,14,23,24,27)$. In the lower elevation forests, it prefers thick, regenerating vegetation and lower layers of the canopy $(14,27)$. It is also commonly seen on the ground $(7,27)$. It is apparently absent from disturbed areas of Kibale Forest (29) and is strongly associated with those areas of mature forest where canopy cover is greater than $15 \mathrm{~m}(26)$. Diets are varied and it is an opportunistic, eclectic feeder $(18,27)$, concentrating on fruits from many tree species (14). Polyspecific groups are frequently observed, both with Colobus monkeys and other Guenons $(14,18)$. Social structure usually consists of one-male groups, with a mean group size of 10-17 animals in Kibale $(4,29)$ and 17 in Bwindi (18); large bands have also been observed (7). Home range sizes are large for Forest Guenons (4): about $10 \mathrm{sq}$. km (18). In the Ruwenzori Mountains, groups have been observed descending $600 \mathrm{~m}$ into the foothills in a single day to raid crops (7). Little is known of their reproductive parameters in the wild, but births appear to be seasonal (4).

THREATS The primary threat to $C$. lhoesti is deforestation. They are one of the few forest species that appears not to survive even under very light conditions of logging, and require dense canopy, mature vegetation (26). They are also hunted in some areas (8). In the Kivu region of Zaire, much of the montane forest was destroyed by 1975 , with wildlife non-existent and a dense human population (31). Whether $C$. lhoesti survives in much of this region needs to be determined. In Burundi and Rwanda, exapanding human populations have increased the pressure to exploit remaining areas of forested habitats for cultivation, grazing, timber and mineral resources $(6,25,32)$. In Uganda, the species was hunted in colonial times for food and its skin (7). More recently, it may have come under poaching pressure during the mid-1970s when much of Uganda's wildlife was slaughtered by Ugandan and Tanzania troops $(2,3,15,17,22)$. While $C$. Ihoesti may have been protected from the worst of this poaching due to the inaccessible nature of much of its habitat, poaching of forest primates is a continuing problem since enforcement of hunting regulations remains difficult (8). Severe human encroachment on existing reserves and national parks is also a problem for a species sensitive to light levels of disturbance. Logging and agricultural encroachment were extensive in parts of Bwindi, Kibale 
and Semliki Forest Reserves (8,9,17), and Ruwenzori National Park is similarly threatened (17). Despite strong legislation protecting parks, development projects were initiated in the heart of Ruwenzori (15); the reserves have weak status and their protection can be removed easily (15).

CONSERVATION MEASURES The most urgent conservation measure is the protection of remaining areas of habitat, which are under severe pressure throughout the species" range. Thus, surveys of the status and distribution of the species are needed and immediate protection given to remaining areas of habitat containing viable populations.

The species is not covered by legislation restricting hunting or export in Zaire (13). In Burundi, export of $C$. lhoesti is illegal, and it can only be exported from Rwanda under permit (13). In Uganda, permits are required to trap or export C. lhoesti (13). Surveys for its presence in protected areas are needed in Zaire, Burundi and Rwanda. No information on its presence in protected areas is available for Zaire. In Burundi, it is not known if the species is found in Kibira National Park or in the Rumango-Bururi Forest Reserves. The species is known from the Nyungwe Forest Reserve in Rwanda (10), but this area has been disturbed by logging and mining activities (25). They may also occur in the Parc de Volcans in Rwanda. In Uganda, after initial surveys, it was proposed that: i) Bwindi and Kibale Forest Reserves be upgraded to national park status; ii) a new category of reserve be established with full legal protection but restricted tourism; iii) all reserves be vigorously protected against encroachment, including the demarkation of boundaries by exotic tree species such as cypress $(8,15,17)$. The training and equipping of anti-poaching units began in 1981 with extensive support from conservation bodies, and has resulted in declines in levels of poaching (17).

The species is listed in Class B of the African Convention (1969); it may be hunted, killed, captured or collected only under special authorization granted by the competent authority.

It is included on Appendix 2 of the 1973 Convention on International Trade in Endangered Species of Wild Fauna and Flora, trade in it between acceding nations being subject to regulation and monitoring of its effects.

CAPTIVE BREEDING In 1983 the species had bred at Mulhouse Zoo and Royan Zoo in France (21).

REMARKS For a description see $(7,11)$. C. lhoesti and C. preussi are sometimes regarded as subspecies $(5,12,14,20,23,33)$, but are more commonly regarded as similar species with disjunct ranges $(11,19,30)$.

\section{REFERENCES}

1. Albrecht, H. (1976). Chimpanzees in Uganda. Oryx 13(4): 357-361.

2. Anon. (1979). Shocking news from Uganda. Swara 2(2): 23.

3. Anon. (1979). Uganda bans hunting - but can poaching be stopped? Swara 2(4): 22.

4. Cords, M. (1987). Forest guenons and Patas monkeys: Male-male competition in one-male groups. In: Smuts, B.B., Cheney, D.L., Seyfarth, R.M., Wrangham, R.W. and Struhsaker, T.T. (Eds), Primate Societies. University of Chicago Press, Chicago.

5. Dandelot, P. (1974). Part 3: Order Primates. In: Meester, J. and Setzer, H. W. (Eds), (1971-77). The Mammals of Africa: An Identification Manual. Smithsonian Institution Press, City of Washington.

6. Fitter, R. and Fitter, M. (1974). Ceylon and Rwanda. Oryx 12(4): 475-478.

7. Haddow, A.J. (1952). Field and laboratory studies on an African monkey, Cercopithecus ascanius schmidti Matschie. Proceedings of the Zoological Society of London 122: 297-394.

8. Harcourt, A.H. (1980). Gorillas in Bwindi Forest Reserve, Uganda. WWF Monthly Re port February 1980.

9. Harcourt, A.H. (1980-81). Can Uganda's gorillas survive? - A survey of the Bwindi Forest Reserve. Biological Conservation 19: 269-282.

10. Harcourt, A.H. (1983). Note from a corresponding member of Conservation Working Party on the Nyungwe Forest, Rwanda. Primate Eye 20: 11-12. 
11. Hill, W.C.O. (1966). Primates, Comparative Anatomy and Taxonomy, Volume VI. Edinburgh University Press, Edinburgh.

12. Honacki, J.H., Kinman, K.E. and Koeppl, J.W. (Eds) (1982). Mammal Species of the World. Allen Press Inc. and The Association of Systematics Collections, Lawrence, Kansas.

13. Kavanagh, M. and Bennett, E.L. (1984). A synopsis of legislation and the primate trade in habitat and user countries. In: Mack, D. and Mittermeier, R.A., International Trade in Primates. TRAFFIC (U.S.A.).

14. Kingdon, J. (1971). East African Mammals: An Atlas of Evolution in Africa, Vol. 1. Academic Press, London.

15. Malpas, R.C. (1981). Uganda's wildlife: Planning for the future. Wildlife News 16(2): 12-16.

16. Malpas, R.C. (1982). Rehabilitating conservation in Uganda. WWF Monthly Report January 1982.

17. Malpas, R.C. (1982). Uganda, conservation of wildlife and wildlife habitats. Report of WWF Project 1942.

18. Moller (1971). Pers. comm. In: Kingdon, J., East African Mammals: An Atlas of Evolution in Africa, Vol. 1. Academic Press, London.

19. Napier, J.R. and Napier, P.H. (1967). A Handbook of Living Primates. Academic Press, London.

20. Nowak, R.M. and Paradiso, J.L. (1983). Walker's Mammals of the World. 4th Edition. The Johns Hopkins University Press. Baltimore and London.

21. Olney, P.J.S. (Ed.) (1986). International Zoo Yearbook 24/25. Zoological Society of London.

22. Orsdol, K.G. van (1980). Slaughter of the innocents. Animal Kingdom 82(6): 19-26.

23. Rahm, U.H. (1970). Ecology, zoogeography and systematics of some African forest monkeys. In: Napier, J.E. and Napier, P.H. (Eds), Old World Monkeys: Evolution, Systematics and Behavior. Academic Press, New York.

24. Rahm, U.H. and Christiaensen, A.R. (1963). Les mammifères de la région occidentale du Lac Kivu. Ann. Mus. Roy. Afr. Cent., Tervuren Sci. Zool. 41: 215-220.

25. Rodgers, W.A. (1981). Brief report on the conservation status of the Nyungwe Forest, Rwanda, with comments on similar forests in Rwanda and Burundi. Unpublished Report.

26. Skorupa, J.P. (1986). Responses of rainforest primates to selective logging in Kibale Forest, Uganda: A summary report. In: Benirschke, K. (Ed.), Primates: The Road to Self-Sustaining Po pulations. Springer-Verlag, London.

27. Struhsaker, T.T. (1969). Correlates of ecology and social organization among African cercopithecines. Folia Primatologica 11: 80-118.

28. Struhsaker, T.T. (1974). Pers. comm. In: Wolfheim, J.H. (1983). Primates of the World: Distribution, Abundance and Conservation. University of Washington Press, Seattle and London.

29. Struhsaker, T.T. (1975). The Red Colobus Monkey. University of Chicago Press, Chicago.

30. Tappen, N.C. (1960). Problems of distribution and adaptation of the African monkeys. Current Anthropology 1:91-120.

31. Verschuren, J. (1975). Wildlife in Zaire. Oryx 13(1): 25-33.

32. Verschuren, J. (1978). Burundi and wildlife: Problems of an overcrowded country. Oryx 14(3): 237-240.

33. Wolfheim, J.H. (1983). Primates of the World: Distribution, Abundance, and Conservation. University of Washington Press, Seattle and London. 


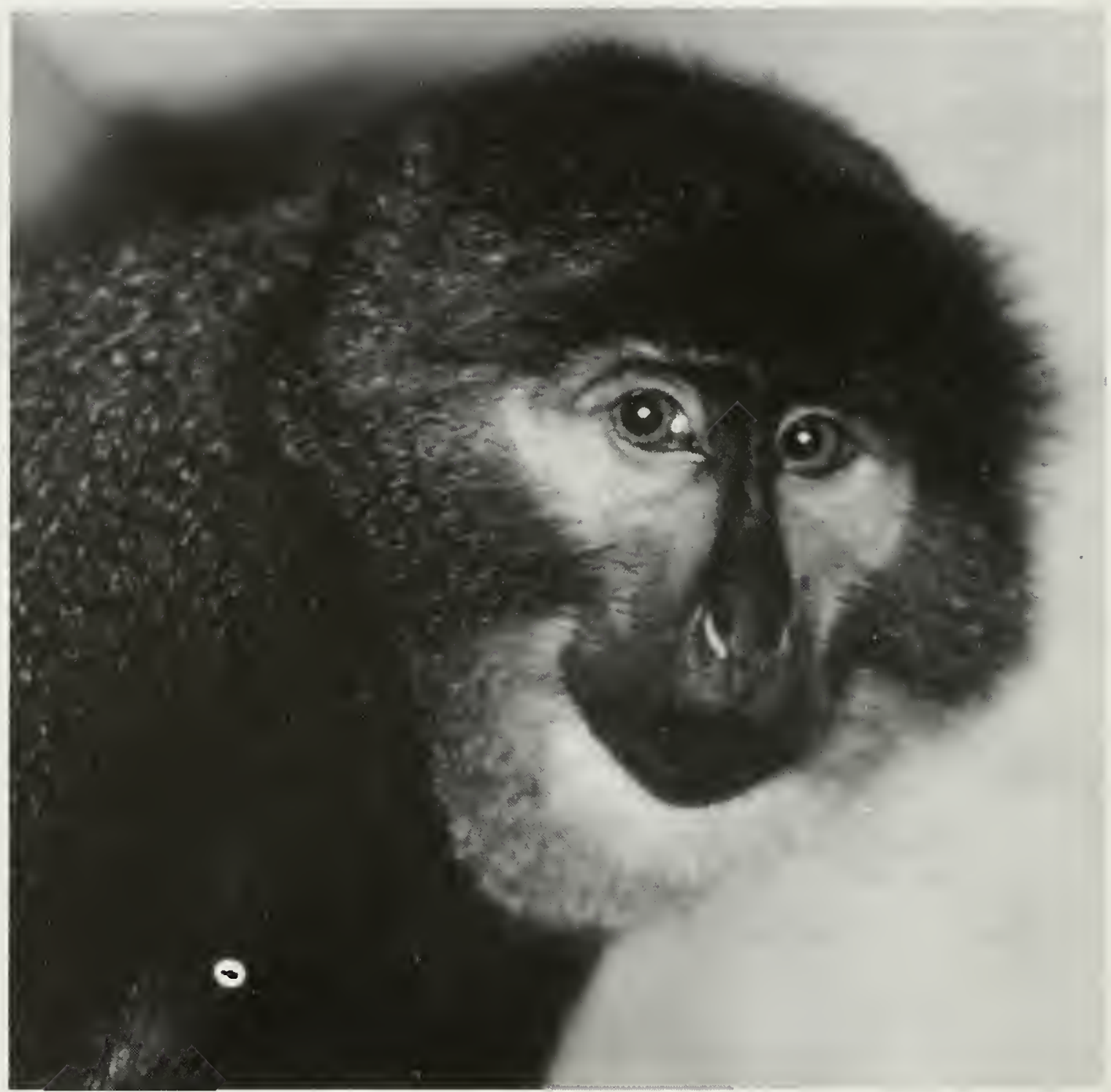

Preuss's Guenon Cercopithecus preussi is found in montane forests only in Southern Nigeria, Cameroon, and the island of Bioko (Equatorial Guinea). Numbers are thought to be declining as a result of deforestation and hunting.

Photo by Russell A. Mittermeier, WWF-US. 
The IUCN Red Data Book

ENDANGERED

Cercopithecus preussi Matschie, 1898

Order PRIMATES

Family CERCOPITHECIDAE

SUMMARY Preuss's Guenon is a montane forest species with a distribution limited to southern Nigeria and Cameroon, on or around Mount Cameroon, and the island of Bioko (Equatorial Guinea) in West Africa. No population estimates exist, but numbers are thought to be declining as a result of habitat destruction and hunting within its very limited range. The species is particularly vulnerable due to its restricted distribution. Surveys of its status and distribution are urgently needed, and full protection of remaining habitats and enforcement of hunting regulations are required. No members of this species are known to be held in captivity. The species is listed in Class B of the African Convention and in Appendix 2 of CITES.

DISTRIBUTION C. preussi occurs only in Nigeria, Cameroon and on the island of Bioko. In Nigeria, it is restricted to the extreme south-east, south of about $7^{\circ} \mathrm{N}(8,20)$ and east of the Cross River at about $8^{\circ} \mathrm{E}(2)$. It probably occurs at the edge of the Obudu Plateau, although there are no recent records of its presence (15). In Cameroon, the species is found only in an area of less than $120 \mathrm{~km}$ by $120 \mathrm{~km}$ (5) between the Sanaga River in the south and the Nigerian border in the north-west (2). There is no information on its distribution in Bioko.

POPULATION Total numbers are unknown. In 1974, the species was common in Cameroon only in the area of Mt Cameroon, being absent elsewhere (6). Numbers were thought to be declining as its range was being reduced in the area (6). There are no estimates of populations in Nigeria or Bioko.

HABITAT AND ECOLOGY C preussi is found mainly in primary and old secondary montane rain forest above $1000 \mathrm{~m}(5,7)$. It can occur in isolated forest patches in mountainous grasslands (18). It is an eclectic and opportunistic feeder (19) which frequently joins polyspecific associations with other Guenons (7). Groups tend to be small, ranging between 2-9 with a mean size of $4(5,19)$, and composed of a single adult male with one or more females. Adult males give loud calls in the early evening (19), but are otherwise quiet monkeys (12).

THREATS Deforestation and hunting are the major threats. By 1974, the forests of the Mt Cameroon area were being logged, drastically reducing the habitat available to $C$. preussi, and forcing them further up the mountain. Hunting and trapping within their range was reducing populations further (6). In the Oban Hills Forest Reserves of Nigeria, the remaining relict patches of forest on mountainous slopes are under pressure from cultivation and logging, and hunting of primates for meat is widespread (15). No information on the status of the species is available from Bioko, although the confiscation of firearms in 1976 has reduced hunting pressures and remote areas with poor soils for agriculture have been left relatively undisturbed (3).

CONSERVATION MEASURES Permits are required to hunt, trap or export primates in Nigeria and Cameroon (11). Enforcement of these laws and strict restrictions on hunting of threatened species are essential. Significant populations of C. preussi may exist in the Oban Hills Forest Reserves of Nigeria $(15,16)$, and in the mountains near Obudu (16). Surveys of these areas are needed and the protected status of reserves needs to be effectively enforced. Proposals for the creation of national parks in the Oban Hills and Obudu area should be implemented. In Cameroon, Korup National Park may contain some $C$. preussi, although the population density is likely to be low since the species has only been recorded once (1). Remaining areas of habitat on and around Mt Cameroon need to be strictly protected from encroachment and poaching. The species may occur in the Takamanda Reserve, but the area remains poorly known (16). On Bioko, plans for integrating conservation priorities with the development of natural resources, and conservation education programmes to alert residents to the value of forest resources have been proposed and need implementation (3). Surveys of the 
status and distribution of $C$. preussi are urgently needed in all remaining areas where the species could occur.

The species is listed in Class B of the African Convention (1969); it may be hunted, killed, captured or collected only under special authorization granted by the competent authority.

It is also listed in Appendix 2 of the 1973 Convention on International Trade in Endangered Species of Wild Fauna and Flora, trade in it between acceding nations being therefore subject to regulation and monitoring of its effects.

CAPTIVE BREEDING None are known to be held in captivity.

REMARKS For description see $(4,9,18)$. C. preussi and Cerco pithecus lhoesti are commonly regarded as separate species (e.g. $9,13,20$ ) as cited in the RDB; however they are also sometimes considered to be conspecific with C. lhoesti taking precedence (e.g. 10,12,14,17,21).

In 1984 a population closely related to the lhoesti-preussi Guenons was discovered by Mike Harrison in Gabon; in 1988 it was named as a new species Cercopithecus solatus, the Sun-tailed Guenon. It is listed in the Red Data Book as "Vulnerable".

\section{REFERENCES}

1. Agland, P. (1984). Pers. comm.

2. Booth, A.H. (1958). The zoogeography of West African primates: A review. Bull. Inst. Fondam. Afr. Noire 20: 587-522.

3. Butynski, T.M. and Koster, S.H. (1986). Preliminary outline for three conservation activities on Bioko Island (Fernando Po), Equatorial Guinea. Unpublished report to IUCN/WWF.

4. Dandelot, P. (1974). Part 3: Order Primates. In: Meester, J. and Setzer, H.W. (Eds), (1971-77). The Mammals of Africa: An Identification Manual. Smithsonian Institution Press, Washington D.C.

5. Gartlan, J.S. (1973). Influences of phylogeny and ecology on variations in the group organization of primates. In: Menzel, E.W. (Ed.), Precultural Primate Behaviour. Symposium of the 4th International Congress of Primatology. Vol. 1. Karger, Basel.

6. Gartlan, J.S. (1974). Pers. comm. In: Wolfheim, J.H. (1983). Primates of the World: Distribution, Abundance and Conservation. University of Washington Press, Seattle and London.

7. Gartlan, J.S. and Struhsaker, T.T. (1972). Polyspecific associations and niche separation of rain-forest anthropoids in Cameroon, West Africa. Journal of Zoology 168: 221-266.

8. Happold, D.C.D. (1971). A Nigerian high forest reserve. In: Happold, D.C.D. (Ed.), Wildlife Conservation in West Africa. IUCN Publication New Series 22: 58-59.

9. Hill, W.C.O. (1966). Primates, Comparative Anatomy and Taxonomy, Volume VI. Edinburgh University Press, Edinburgh.

10. Honacki, J.H., Kinman, K.E. and Koeppi, J.W. (Eds) (1982). Mammal Species of the World. Allen Press Inc. and the Association of Systematics Collections, Lawrence, Kansas.

11. Kavanagh, M. and Bennett, E.L. (1984). A synopsis of legislation and the primate trade in habitat and user countries. In: Mack, D. and Mittermeier, R.A. (Eds), International Trade in Primates. TRAFFIC (U.S.A.).

12. Kingdon, J. (1971). East African Mammals: An Atlas of Evolution in Africa, Vol. 1. Academic Press, London.

13. Napier, J.R. and Napier, P.H. (1967). A Handbook of Living Primates. Academic Press, London.

14. Nowak, R.M. and Paradiso, J.L. (1983). Walker's Mammals of the World. 4th Edition. 4th Edition. The Johns Hopkins University Press. Baltimore and London.

15. Oates, J.F. (1984). In litt.

16. Oates, J.F. (1986). IUCN/SSC Primate Specialist Group Action Plan for African Primate Conservation: 1986-90. IUCN/WWF, Gland and Cambridge. 
17. Rahm, U.H. (1970). Ecology, zoogeography and systematics of some African forest monkeys. In: Napier, J.E. and Napier, P.H. (Eds), Old World Monkeys: Evolution, Systematics and Behavior. Academic Press, New York.

18. Sanderson, I.T. (1940). The mammals of the North Cameroons Forest area. Being the results of the Percy Sladen Expedition to the Mamfe Division of the British Cameroons. Transactions of the Zoological Society of London 24: 623-725.

19. Struhsaker, T.T. (1969). Correlates of ecology and social organization among African cercopithecines. Folia Primatologica 11: 80-118.

20. Tappen, N.C. (1960). Problems of distribution and adaptation of the African monkeys. Current Anthro pology 1: 91-120.

21. Wolfheim, J.H. (1983). Primates of the World: Distribution, Abundance, and Conservation. University of Washington Press, Seattle and London. 

The IUCN Red Data Book

VULNERABLE

Cercopithecus solatus Harrison, 1988

Order

PRIMATES

Family CERCOPITHECIDAE

SUMMARY Cercopithecus solatus is a recently described species of Guenon endemic to tropical lowland rain forest in central Gabon. It has a very restricted distribution and is rare throughout its range. It is under imminent threat from forestry exploitation and is hunted. Little is known of its habits, and further studies are needed on all aspects of the species' biology. A small number are currently held in captivity. It is listed in Class B of the African Convention and in Appendix 2 of CITES.

DISTRIBUTION The species is thought to be restricted to a large undisturbed forest block in central Gabon south of the Ogooué River between $0^{\circ} 5^{\prime}-1^{\circ} 30^{\prime} \mathrm{S}, 11^{\circ} 45^{\prime}-12^{\circ} 30^{\prime} \mathrm{E}$ (1). Its distribution is roughly bounded on the west, north and east by the Offoué and Ogooué Rivers and to the south by human settlements and savannah (1). It was first discovered in the Forêt des Abeilles and preliminary surveys of its distribution were completed in 1987. Its total range is thought to be less than $9000 \mathrm{sq} . \mathrm{km}(2)$.

POPULATION No estimates are available, but it is probably extremely rare since it was only discovered in 1984 despite the relative accessibility of many forested areas of Gabon.

HABITAT AND ECOLOGY The species is known only from one lowland rain forest in Gabon. It is reported by local hunters to be predominantly terrestrial and is occasionally caught in snares (2). It is a quiet species that occasionally raids crops (2). Little is known of its diet or social organization in the wild, but in captivity it readily eats most fruits and vegetables (2).

THREATS The species is hunted for meat, and was first discovered when it was shot for hunters' food while Harrison was censusing primates in the forest (1). One live individual was recovered from a non-local hunter who had kept it as a pet since he had not seen such a monkey before (1). Logging is a threat to its forest habitat. While logging in the Forêt des Abeilles has temporarily stopped, hunting pressures have increased with expansion of human activities into the forest. Logging is likely to be less of a direct problem for the Guenons than hunting since the trees removed on a selective basis tend not to be food species (1). The rarity of this species, combined with a very restricted distribution and threats from hunting and logging, make it vulnerable to major declines in population.

CONSERVATION MEASURES Surveys of the distribution of this new species have recently been carried out by J.P. Gautier in order to recommend areas to the Direction-Générale des Eaux et Fôrets that can be included within the protected area of Lopé Reserve (1). The authorities are willing to incorporate new areas into the reserve, but logging concessions are still held by a logging company. Hunting within the reserve, including any newly added areas, urgently needs to be controlled, both to guarantee the survival of the Sun-Tailed Guenon and all the other resident primates within the reserve (1). The recent discovery of this species highlights the importance of tropical forests as genetic reserves, and the necessity for effective and rapid conservation integrated with development activities. Since this species was previously unknown, it is not yet included under any protective legislation. More detailed studies of its distribution and biology are urgently needed.

Included in Class B of the African Convention (1969); it may be hunted, killed, captured or collected only under special authorization granted by the competent authority.

Listed on Appendix 2 of the 1973 Convention on International Trade in Endangered Species of Wild Fauna and Flora, trade in it between acceding nations being therefore subject to regulation and monitoring of its effects. 
CAPTIVE BREEDING A colony of three animals is kept at the CIRMF Primatology Centre in Gabon, and a further three are in France (1).

REMARKS For a description see (2). The species is thought to be closely related to the lhoesti group of Cerco pithecus monkeys, separated from populations in Zaire, Rwanda and Uganda by $1600 \mathrm{~km}$, and from populations of $C$. preussi in Cameroon by $600 \mathrm{~km}$ (2).

Michael Harrison kindly commented on this data sheet.

\section{REFERENCES}

1. Harrison, M.J.S. (1984-88). In litt.

2. Harrison, M.J.S. (1988). A new species of guenon (genus Cercopithecus) from Gabon. Journal of Zoology in press. 


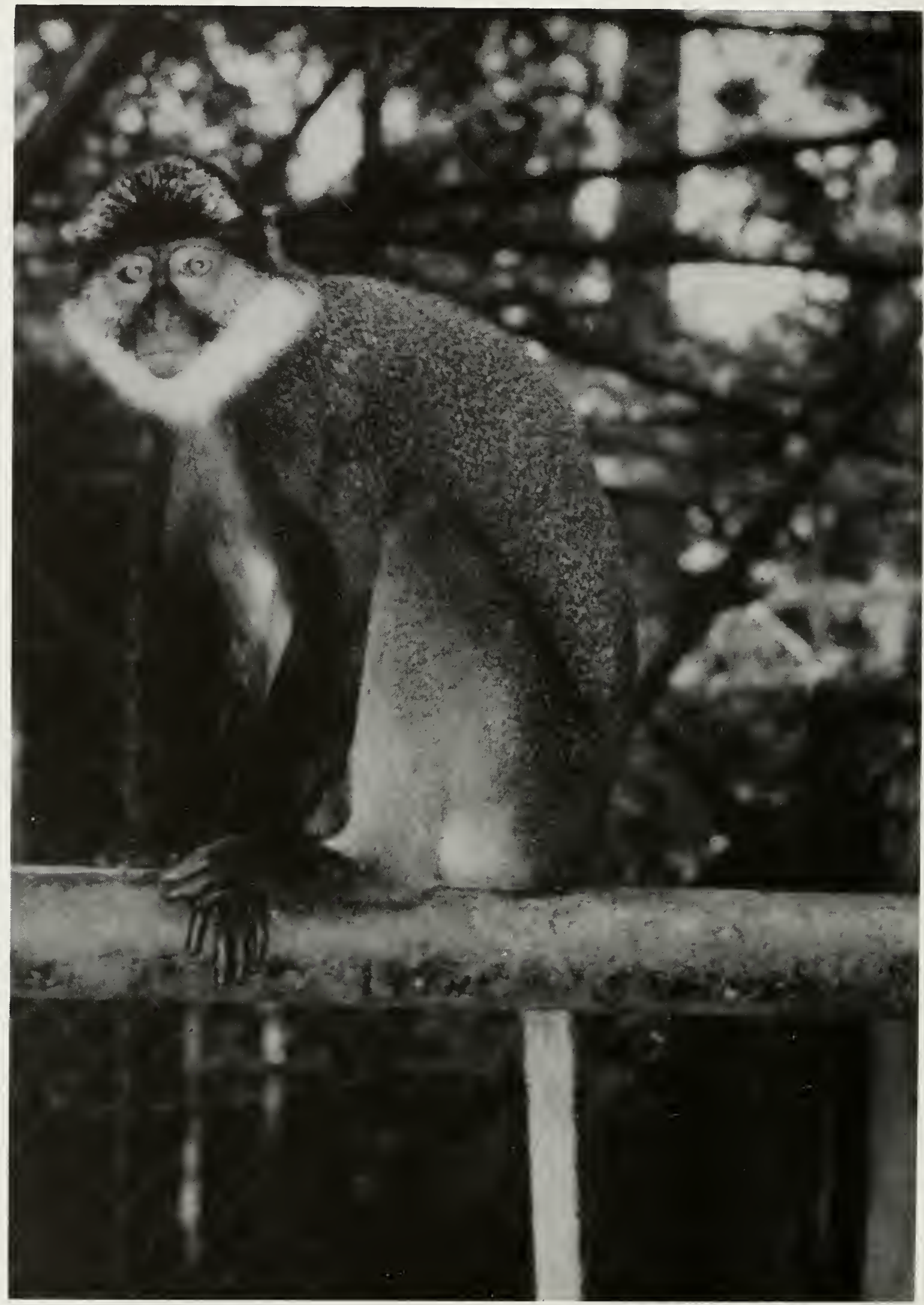

The "Endangered" White-throated Guenon Cercopithecus erythrogaster is found only in forests in south-west Nigeria. Deforestation has left only scattered patches of habitat and hunting pressures are severe.

Photo by J.F. Oates 
The IUCN Red Data Book

ENDANGERED

\author{
Cercopithecus erythrogaster Gray, 1866
}

Order PRIMATES

Family CERCOPITHECIDAE

SUMMARY The highly endangered White-throated Guenon is a small bodied animal living in forest patches in south-west Nigeria, and possibly in Benin. It is threatened by habitat destruction and increasing fragmentation of forests within its range. Hunting is a further threat. Numbers are estimated to be small and declining. Stringent habitat protection and hunting restrictions are necessary. A few are held in captivity. The species is listed in Class B of the African Convention and in Appendix 2 of CITES.

DISTRIBUTION The species is widespread in lowland forests in south-western Nigeria, between Ijebu-Ode $\left(3^{\circ} 54.5^{\prime} \mathrm{E}, 6^{\circ} 49^{\prime} \mathrm{N}\right)$ and the Niger River $(5,1,17,3,13,18)$. It is now confined to small, isolated forest patches $(1,13)$. It was thought to occur in Benin, on the Nigerian border $(2)$, but the evidence is based on a single captive animal (16).

POPULATION Surveys in $1981 / 82$ by Oates found populations scattered in many of the remaining high forest areas of south-western Nigeria $(10,11,13)$. Densities in the Okomu Forest were higher than elsewhere and averaged 1 group per sq.km (13). By extrapolating the survey results to similar data on the densities of $C$. ascanius in Kibale Forest, Uganda, numbers in Okomu were estimated to be 6000 animals (13). The estimates remain highly tentative (13). Total numbers are unknown but are thought to be declining along with the loss of habitat.

HABITAT AND ECOLOGY In the lowland rain forest zone, the species is found in high canopy forests, secondary forests $(10,11)$, and in bush and old farmland close to high forests (8). It prefers dense, tangled vegetation and tends to be found between $2-15 \mathrm{~m}$ above the ground (13). The animals are diurnal and arboreal $(1,9)$, with a diet of fruit and possibly insects (13). Social organization is poorly known. They are thought to live in groups composed of one male accompanied by several fernales and their offspring (13). Foraging groups tend to be around 5 animals (13), but groups of more than 30 animals have been reported (8). Reproductive parameters in the wild are unknown.

THREATS The forests of south-western Nigeria have been intensively exploited, and now exist only as small, isolated patches $(1,10,11,13)$. Timber extraction (both legal and illegal) continues even within reserve areas (13). Farming, road construction, oil exploration and conversion to plantations have all reduced the extent of forests $(1,10,11,13)$. Hunting of primates and most forest wildlife for meat is intense in the area (13).

CONSERVATION MEASURES While the species is known from at least 12 forest reserves in Nigeria (13), effective management and protection of the reserve areas are essential. C. erythrogaster can apparently survive in dense secondary forests within very small areas; a group was seen in the 5 sq.km Udo Forest Reserve (13). However, such tiny genetically-isolated populations may not be viable over the long-term and protection of remaining forests, especially those containing relatively large populations such as Okomu, should be made effective. A $67 \mathrm{sq} . \mathrm{km}$ wildlife sanctuary at the centre of Okomu was gazetted in 1985 $(1,11,14,15)$, within which hunting and tree-felling are prohibited. This should be implemented in conjunction with more complete protection of two smaller strict nature reserves - Ifon and Omo Forest Reserves. The species is not specifically protected by hunting regulations (7). Effective hunting regulations are required.

The species is listed in Class B of the African Convention (1969); it may be hunted, killed, captured or collected only under special authorization granted by the competent authority.

It is included in Appendix 2 of the 1973 Convention on International Trade in Endangered Species of Wild Fauna and Flora, and trade in it or its products is thus subject to monitoring by ratifying nations. 
CAPTIVE BREEDING A pair have been kept in Ibadan Zoo since 1970 (and were still alive in 1982 (12)), and at least one adult male and four adult females are in other Nigerian zoos, but none have ever bred (1).

REMARKS For description see $(4,6,10)$.

\section{REFERENCES}

1. Anadu, P.A. and Oates, J.F. (1982). The status of wildlife in Bendel State, Nigeria, with recommendations for its conservation. Report of IUCN/WWF Project 1613.

2. Asibey, E.O.A. (1978). Primate conservation in Ghana. In: Chivers, D.J. and Lane Petter, W. (Eds), Recent Advances in Primatology,Vol.2, Conservation. Academic Press, London.

3. Booth, A.H. (1958). The zoogeography of West African primates: A review. Bull. Inst. Fondam. Afr. Noire 20: 587-622.

4. Dandelot, P. (1974). Part 3: Order Primates. In: Meester, J. and Setzer, H.W. (Eds), (1971-77). The Mammals of Africa: An Identification Manual. Smithsonian Institution Press, Washington, D.C.

5. Haltenorth, T. and Diller, H. (1980). A Field Guide to the Mammals of Africa including Madagascar. Collins, London. English translation.

6. Hill, W.C.O. (1966). Primates, Comparative Anatomy and Taxonomy, Vol. VI. Edinburgh University Press, Edinburgh.

7. Kavanagh, M. and Bennett, E.L. (1984). A synopsis of legislation and the primate trade in habitat and user countries. In: Mack, D. and Mittermeier, R.A. (Eds), International Trade in Primates. TRAFFIC (U.S.A.).

8. Mason, P.F. (1940). A brief faunal survey of north-western Benin. I. Mammals. Nigerian Field 9: 17-22.

9. Nowak, R.M. and Paradiso, J.L. (1983). Walker's Mammals of the World, 4th Edition. The Johns Hopkins University Press, Baltimore and London.

10. Oates, J.F. (1982). In search of rare forest primates in Nigeria. Oryx 16(5): 431-436.

11. Oates, J.F. (1983). Primates of the Nigerian rainforest. WWF Monthly Report January: 399-402.

12. Oates, J.F. (1984). In litt.

13. Oates, J.F. (1985). The Nigerian Guenon, Cerco pithecus erythrogaster: Ecological, behavioural, systematic and historical observations. Folia Primatologica 45: 25-43.

14. Oates, J.F. (1988). In litt.

15. Oates, J.F. and Davies, A.G. (1986). Primate Conservation in West Africa. Unpublished report for the Primate Society of Great Britain.

16. Sayer, J.A. and Green, A.A. (1984). The distribution and status of large mammals in Benin. Mammal Review 14(1):

17. Tappen, N.C. (1960). Problems of distribution and adaptation of the African monkeys. Current Anthropology 1: 91-120.

18. Wolfheim, J.H. (1983). Primates of the World: Distribution, Abundance and Conservation. University of Washington Press, Seattle and London. 
The IUCN Red Data Book

RUSSET-EARED or RED-EARED NOSE-SPOTTED GUENON

ENDANGERED

\author{
Cercopithecus er ythrotis Waterhouse, 1838
}

Order

PRIMATES

Family CERCOPITHECIDAE

SUMMARY The Russet-eared Guenon is a poorly known monkey found only in southern Nigeria, northern Cameroon, and Bioko Island (Equatorial Guinea). The species lives in primary lowland rain forest, and is threatened by hunting and habitat destruction. It is protected within forest reserves, but adequate practical enforcement of reserve status is necessary. Stringent regulation of hunting is also required within its restricted range. Further data on the habitats and ecology of these Guenons are needed. It has been known to breed in captivity. It is listed in Class B of the African Convention and in Appendix 2 of CITES.

DISTRIBUTION The species is found in southern Nigeria, in northern Cameroon, and on the island of Bioko (Equatorial Guinea) $(3,4,14,22)$. Its distribution within this area is poorly known. Three subspecies are recognized. C. e. camerunensis occurs in south-eastern Nigeria and northern Cameroon on the upper course of the Cross River, between the Benue and Sanaga Rivers $(5,22)$. C. e. erythrotis is endemic to Bioko $(5,19)$. The third subspecies, C. e. sclateri has a patchy distribution around the delta and lower course of the Niger River in southern Nigeria (5). A brief survey in early 1988 located specimens within the AGIP Akri oil field on the Niger flood plain west of Oguta, Imo State (16). This subspecies may be distinct enough to merit recognition as a separate species $(15,16)$.

POPULATION No estimates are available. It was thought to be uncommon in 1958 (3), rare in southern Nigeria in 1960 (22) and declining in the Mungo Forest Reserve in 1974 (11). Densities in the Lombé part of Douala-Edea Reserve, Cameroon, were reported as 2-3 groups per sq.km, but populations elsewhere in the reserve had declined significantly due to hunting (13). It was thought to be abundant only in Korup National Park, Cameroon (23). C. e. sclateri is thought to have declined in numbers and may be threatened with extinction $(15,17)$. There is no information on population sizes on Bioko.

HABITAT AND ECOLOGY The Guenons are found in primary lowland rain forest, but are also present in secondary, immature and seasonally flooded forest $(8,20)$. They are diurnal and arboreal, but preferences for different canopy heights are unclear $(8,19,20)$. Diets are unknown. Group size ranges from four to over 30, and solitary males have been observed (20). Large, multi-male groups were frequently found in Cameroon (6), and polyspecific associations have been noted ( 8 ). No further information on ecology or reproduction is available.

THREATS Habitat destruction and hunting are the primary threats. By 1974, rapid deforestation was occurring throughout most of its limited geographical range in Nigeria and Cameroon (23). The 1988 survey of C.e. sclateri found that the Akri area it inhabited was under heavy human exploitation. This included widespread farming (especially of cassava), tree cutting (for fuel and timber), and oil exploration and extraction (16). The species is hunted for meat in both Nigeria and Cameroon $(1,12,16,23)$. It is not adequately protected (17) and encroachment on reserves for agricultural land, timber and poaching for meat is widespread $(2,17,21)$.

On Bioko, wildlife in remote areas has been spared agricultural development due to poor soils which are incapable of retaining water year-round and a decline in human population pressures (4). The majority of firearms were confiscated in 1974, and primate populations may have recovered in the absence of hunting (4). With a return to economic and political stability, pressures to develop the island's natural resources may threaten remaining areas of habitat (4).

CONSERVATION MEASURES Permits are required to trap, hunt or export all monkeys in both Nigeria and Cameroon (12). These laws need to be enforced, particularly in regard to the hunting of threatened species. C. erythrotis is protected within the Douala-Edea Reserve and the recently (1984) gazetted Korup National Park in Cameroon. Douala-Edea has been 
proposed as a national park (7) and illegal loggers were expelled in 1976 (2). However, the area is under pressure from proposals for oil exploration, and resident populations of $C$. erythrotis need protection. The Oban Hills Forest Reserves in Nigeria contain populations of this species. The reserves are threatened by logging and primates are extensively hunted (15). Proposals for a national park in the area have yet to be acted upon (15). The species is also reported to occur in the Sonkwala Mountains, in the area of the Afi River and Boshi-Okwango Forest Reserves (9). The subspecies C. e. sclateri was the object of a brief survey in late 1987/early 1988; a more thorough survey will be conducted in January and February 1989 sponsored by the National Geographic Society. The recent survey could not confirm the presence of Sclater's Guenon in a protected area (16).

The species is unprotected on Bioko (12), although previous hunting pressures may have eased with the confiscation of firearms (4). The integration of conservation priorities with development of resources is essential for Bioko, as the pace of development increases under a stable political climate. Several conservation projects have been proposed, and educational programmes to inform residents of the need to safeguard natural resources have been suggested (4). These projects require funding. Further information on the status, distribution and ecology of the species throughout its range is urgently needed.

C. erythrotis is included in Class B of the African Convention (1969); it may be hunted, killed, captured or collected only under special authorization granted by the competent authority.

It is listed in Appendix 2 of the 1973 Convention on International Trade in Endangered Species of Wild Fauna and Flora, trade in it between acceding nations being therefore subject to regulation and monitoring of its effects.

CAPTIVE BREEDING In 1980, it was bred in Duisburg Zoo, Germany (18).

REMARKS For a description see $(5,10)$.

\section{REFERENCES}

1. Anadu, P.A. and Oates, J.F. (1982). The status of wildlife in Bendel State, Nigeria, with recommendations for its conservation. Report of IUCN/WWF Project 1613.

2. Anon. (1976). Cameroun rainforest. Oryx 13(4): 340.

3. Booth, A.H. (1958). The zoogeography of West African primates: A review. Bull. Inst. Fondam. Afr. Noire 20: 587-622.

4. Butynski, M. and Koster, S. H. (1986). Preliminary outlines for three conservation activities on Bioko Island (Fernando Po), Equatorial Guinea. unpublished report.

5. Dandelot, P. (1974). Part 3: Order Primates. In: Meester, J. and Setzer, H.W. (Eds), (1971-77). The Mammals of Africa: An Identification Manual. Smithsonian Institution Press, Washington D.C.

6. Gartlan, J.S. (1973). Influence of phylogeny and ecology on variations in the group organization of primates. In: Menzel, E.W. (Ed.), Precultural Primate Behavior. Symp. 4th Int. Congr. Primatol., Vol 1. Karger, Basel.

7. Gartlan, J.S. and Agland, P.C. (1980). A proposal for a program of rain-forest conservation and national park development in Cameroun, West-Central Africa. Unpublished report to the Gulf Oil Corporation.

8. Gartlan, J.S. and Struhsaker, T.T. (1972). Polyspecific associations and niche separation of rain-forest anthropoids in Cameroun, West Africa. Journal of Zoology 168: 221-266.

9. Harcourt, A.H., Stewart, K.J., and Inaharo, I.M. (1988). Nigeria's gorillas: a survey and recommendations. Unpublished report to the Nigerian Conservation Foundation.

10. Hill, W.C.O. (1966). Primates, Comparative Anatomy and Taxonomy, Volume VI. Edinburgh University Press, Edinburgh.

11. Howard (1974). Pers. comm. In: Wolfheim, J.H. (Ed.), loc. cit.

12. Kavanagh, M. and Bennett, E.L. (1984). A synopsis of legislation and the primate trade in habitat and user countries. In: Mack, D. Mittermeier, R.A. (Eds), International Trade in Primates. TRAFFIC (U.S.A.).

13. McKey, D.B. (1978). Ph.D thesis, University of Michigan. 
14. Nowak, R.M. and Paradiso, J.L. (1983). Walker's Mammals of the World. The Johns Hopkins University Press, Baltimore and London.

15. Oates, J.F. (1984). In litt.

16. Oates, J.F. (1988). Survey to locate Sclater's Guenon, Part Two. Preliminary Report to the IUCN and the Nigerian Conservation Foundation.

17. Oates, J.F., Gartlan, J.S. and Struhsaker, T.T. (1982). A framework for planning rain-forest primate conservation. International Primate Society Newsletter No. 1.

18. Olney, P.J.S. (Ed.) (1982). International Zoo Yearbook 22. Zoological Society of London.

19. Sanderson, I.T. (1940). The mammals of the North Camerouns Forest area. Being the results of the Percy Sladen expedition to the Mamfe Division of the British Camerouns. Transactions Zoological Society of London 24: 623-725.

20. Struhsaker, T.T. (1969). Correlates of ecology and social organization among African cercopithecines. Folia Primatologica 11: 80-118.

21. Struhsaker, T.T. (1972). Rain-forest conservation in Africa. Primates 13: 103-109.

22. Tappen, N.C. (1960). Problems of distribution and adaptation of the African monkeys. Current Anthropology 1: 91-120.

23. Wolfheim, J.H. (1983). Primates of the World: Distribution, Abundance and Conservation. University of Washington Press, Seattle and London. 

The IUCN Red Data Book

INSUFFICIENTLY KNOWN

Allenopithecus nigroviridis Pocock, 1907

Order

PRIMATES

Family CERCOPITHECIDAE

SUMMARY Allen's Swamp Monkey occurs in riverine and swamp forests of northern Congo (Brazzaville), Zaire and possibly north-east Angola. Population estimates are not yet available, but some large bands are found near areas of human habitation. By day, they forage at ground level and congregate in large associations in riverine or swamp areas to sleep. Their preference for dense riverine or swamp forest may provide some protection, since such areas are relatively inaccessible and difficult to develop. However, hunting in such habitats may pose a threat. The tendency to raid crops may place the species in greater conflict with humans in areas of agricultural development. One male is known to be held in a zoological garden. The species is listed in Class B of the African Convention and in Appendix 2 of CITES.

DISTRIBUTION The Swamp Monkey is confined to northern Congo (Brazzaville) and Zaire $(2,14,17)$ and possibly north-eastern Angola $(2,5,17)$. In Congo, its distribution extends from about $3^{\circ} 17^{\prime} \mathrm{N}$ in the north to $16^{\circ} 14^{\prime} \mathrm{E}$ in the west (14). In Zaire, it is found on both sides of the Zaire River, from the Oubangui River in the north to $2^{\circ} 17^{\prime} \mathrm{S}(2,17)$. It may occur as far as $7^{\circ} 5^{\prime} \mathrm{s}$ in the Kwango and Wanba Valleys (3). It has been reported from north-eastern Angola (5) with an eastern limit around the Tshuapa River at about $24^{\circ} \mathrm{E}(2,17)$.

POPULATION No estimates of numbers exist. Populations are thought to have declined in recent years throughout the species' range (9).

HABITAT AND ECOLOGY The monkey may be restricted to riverine forests that are regularly innundated (14) although they have been observed temporarily to leave riverine habitats and associate with other species in drier areas (3). They are commonly found in swampy areas (6) as well as adjacent dry ground (3). Diets have not been documented in detail, but Swamp Momkeys are primarily frugivorous and insectivorous and will raid crops, especially manioc (3). Grouping patterns are poorly known; they have been reported as occurring in small, family groups $(1,17)$ although they have also been observed in large "bands" containing several adult males (3). They tend to forage in small monogamous groups at ground level, and congregate at night to sleep in trees 8-20 $\mathrm{m}$ in height on river banks (3). Reproductive parameters are poorly known in the wild.

THREATS Hunting and habitat destruction probably pose threats. Hunting of primates for meat is common in both Congo (Brazzaville) and Zaire, and hunting from rivers is a frequent practice $(7,11,12,15)$. Along the Zaire River and its tributaries upstream from Kinshasa, hunting from boats is so extensive that streamside zones have "mere remnants of wildlife" (7). $A$ nigroviridis is likely to be especially vulnerable to such hunting since it commonly congregates along river banks. Although wildlife away from rivers is less pressured by hunting (7), the occurrence of $A$. nigroviridis in such habitats is unknown. Hunting of Swamp Monkeys in their very dense habitats may be reduced since the areas are difficult to penetrate and humans are noisy and conspicuous in their approach (3). The effects of hunting on the species have yet to be adequately assessed.

Little information is available on the extent of deforestation in the region. While areas of the Abumonbazi Forest between the Zaire and the Oubangui Rivers were intact in 1975, and the forest swamps around Mbandaka were uninhabited at the time (15), logging concessions had been granted by 1981 (12). These consessions are within the range of $A$ nigroviridis. Logging results in increased displacement of the resident primates, and increases pressures from hunters, as well as opening areas to agriculture (12). Some of the dense riverine and swampy habitats of $A$. nigroviridis may be less susceptible to human exploitation, since they are difficult to penetrate (3). The existence of large bands near villages and the presence of crop-raiding groups suggest that the species has not yet been hunted intensively (3). However, as agriculture expands into previously unexploited areas, conflicts between humans and crop-raiding species of 
primates are likely to intensify and pose a serious threat to the survival of a species with both a restricted distribution and narrow habitat preferences.

CONSERVATION MEASURES Surveys on the status, distribution and habitat preferences of $A$ nigroviridis are urgently needed in order to determine conservation priorities. Such surveys are underway in Zaire (3). The species needs legal and practical protection from hunting, and remaining areas of its habitat require protection. $A$ nigroviridis is not known to occur in any national park or protected area in Congo (Brazzaville) $(11,16)$. In the absence of outside financial assistance, wildlife protection in the country is unlikely to be efffective (11). It is not yet known whether $A$ nigroviridis occurs in reserves within Zaire although it is likely to be found in the northern part of Salonga National Park (3).

The species is included in Class B of the African Convention (1969); it may be hunted, killed, captured or collected only under special authorization granted by the competent authority.

It is listed in Appendix 2 of the 1973 Convention on International Trade in Endangered Species of Wild Fauna and Flora, trade in it between acceding nations being therefore subject to regulation and monitoring of its effects.

CAPTIVE BREEDING In 1983, one male was known to be held by Karlsruhe Zoo in West Germany (10).

REMARKS Allenopithecus is sometimes considered as a subgenus of Cercopithecus (e.g. 2). Usually it is given generic status $(5,8,13,17)$ and is considered by Gautier (4) to be an intermediate form between the Cercopithecinae and the Papioninae.

\section{REFERENCES}

1. Cords, M. (1987). Forest guenons and patas monkeys: Male-male competition in one-male groups. In: Smuts, B.B., Cheney, D.L., Seyfarth, R.M., Wrangham, R.W. and Struhsaker, T.T. (Eds), Primate Societies. University of Chicago Press, Chicago.

2. Dandelot, P. (1974). Part 3: Order Primates. In: Meester, J. and Setzer, H.W. (Eds), (1971-77). The Mammals of Africa: An Identification Manual. Smithsonian Institution Press, Washington. D.C.

3. Gautier, J.P. (1984). In litt.

4. Gautier, J.P. (1984). Vocalizations of Allenopithecus nigroviridis and phylogenetic affinities with Cercopithecidae and Papioninae. Paper presented to the Xth Congress of the International Primatological Society. July 22-27, 1984, Nairobi, Kenya.

5. Honacki, J.H., Kinman, K.E. and Koeppi, J.W. (Eds) (1982). Mammal Species of the World. Allen Press Inc. and the Association of Systematics Collections, Lawrence, Kansas.

6. Malbrant, R. and Maclatchy, A. (1949). Faune de l'Equateur Française. 2. Mammifères. Lechevalier, Paris.

7. Myers, N. (1976). Zaire: Nation with a wild future. Animal Kingdom April/May: 2-8.

8. Nowak, R.M. and Paradiso, J.L. (1983). Walker's Mammals of the World. The Johns Hopkins University Press, Baltimore and London.

9. Oates, J.F., Gartlan, J.S. and Struhsaker, T.T. (1982). A framework for planning rain-forest primate conservation. International Primate Society Newsletter No. 1.

10. Olney, P.J.S. (Ed.) (1986). International Zoo Yearbook 24/25. Zoological Society of London.

11. Spinage, C.A. (1980). Parks and reserves in Congo Brazzaville. Oryx 15(3): 292-295.

12. Susman, R.L., Badrian, N., Badrian, A. and Handler, N.T. (1981). Pygmy Chimpanzees in peril. Oryx 16(2): 179-183.

13. Thorington, R.W. Jr. and Groves, C.P. (1970). An annotated classification of the Cercopithecidae. In: Napier, J.R. and Napier, P.H. (Eds), Old World Monkeys. Academic Press, New York.

14. Verheyen, W.N. (1963). New data on the geographical distribution of Cercopithecus (Alleno pithecus) nigroviridis Pocock, 1907. Rev. Zool. Bot. Afr. 68(3-4): 393-396.

15. Verschuren, J. (1975). Wildlife in Zaire. Oryx 13(1): 25-33. 
16. Verschuren, J. (1982). Republique Populaire de Congo. Relance de la conservation de la nature. Unpublished report.

17. Wolfheim, J.H. (1983). Primates of the World: Distribution, Abundance, and Conservation. University of Washington Press, Seattle and London. 


\section{Threatened Primates of Africa}

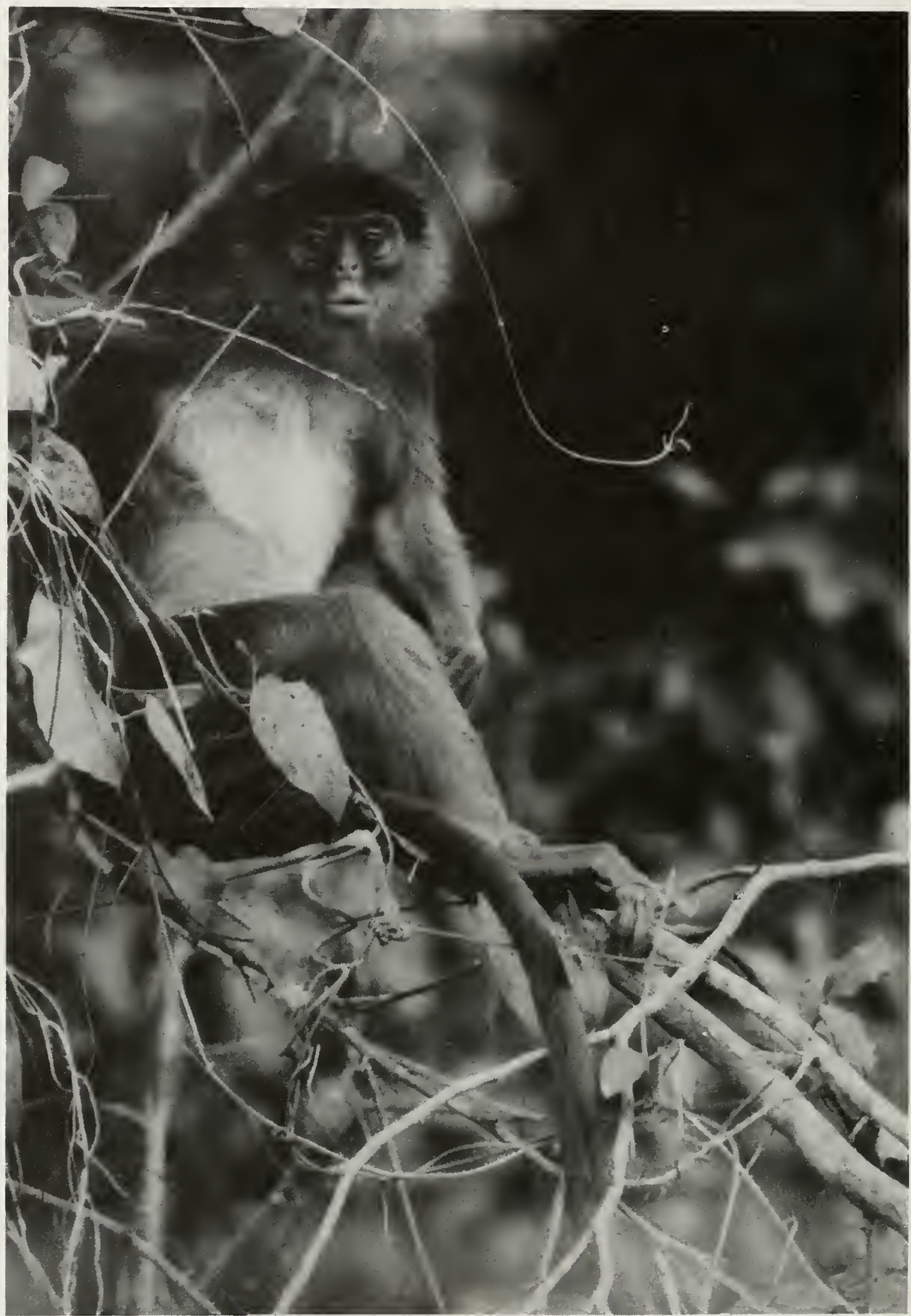

The Temminck's Colobus Procolobus badius temmincki is an arboreal leaf-eater found from Southern Senegal to north-west Guinea. Habitat loss and hunting are likely threats. Photo by D. Starin. 
The IUCN Red Data Book

RED COLOBUS

VULNERABLE

Procolobus badius (Kerr, 1792)

Order PRIMATES

Family CERCOPITHECIDAE

SUMMARY Red Colobus monkeys are relatively large bodied, leaf-eating primates widely distributed in West African forest blocks, extending into central/eastern forests as far as Uganda, Kenya and Tanzania. The taxonomy of the species is confused and there is no general agreement as to classification. The designation Procolobus is used in this publication rather than Colobus (reserved for the Black and White species) or Piliocolobus (a later term). At least 14 subspecies have been recognized, and here they are grouped into forms that are regionally, morphologically and behaviourally distinctive. Following Oates (Action Plan for African Primate Conservation, 1985), five species groups are distinguished within a superspecies [badius].

The Western Red Colobus, Procolobus [badius] badius (badius, temmincki, waldroni), occurs from Senegal to Ghana and is threatened by habitat loss due to logging, and by hunting. The Pennant's Red Colobus, Procolobus [badius] pennanti (pennanti, preussi, bouvieri), is restricted to lowland evergreen forest from Cameroon to Congo (Brazzaville) and the island of Bioko (Equatorial Guinea). These animals are "Endangered" primarily through intensive hunting and forest destruction within their restricted range.

The central/eastern group, Procolobus [badius] rufomitratus (tholloni, oustaleti, foai, ellioti, tephrosceles, rufomitratus), is found in the rain forests of central/eastern Zaire, the mountain forests of Uganda and Tanzania and in the gallery forests along the Tana River, Kenya. The Zairean forms are poorly known, but are thought to be threatened by hunting and deforestation. The main threat to the Ugandan/Tanzanian tephrosceles form is habitat loss from logging and agricultural encroachment. The Kenyan rufomitratus form is on the verge of extinction, and currently totals less than 300 animals within a tiny range. Changes in patterns of gallery forest regeneration as a result of river management and development appear to be the major cause of the catastrophic decline in numbers.

Two further forms are distinctive. Procolobus [badius] gordonorum is found only in the forests of the Uzungwa Mountains, Tanzania. Habitat loss due to logging and agricultural encroachment are serious threats. Procolobus [badius] kirkii is found only on the island of Zanzibar, Tanzania. Selective logging within forest reserves on the island is the major threat.

It should be noted that international efforts and action by the Governments of Tanzania and Kenya have been important in attempts to conserve the "Endangered" Colobus monkeys. Further financial assistance to ongoing conservation projects in these nations is essential to the survival of these rare forms.

Data sheets for each of the five distinctive forms are presented below. 
Procolobus [badius] badius (Kerr, 1792)

Order

SUMMARY The Western Red Colobus group of monkeys are found from Senegal to Ghana in West Africa. Three distinct subspecies are included in this species group. $P$. [b.] b. temminckii is found in southern Senegal, Gambia, Guinea-Bissau and north-west Guinea. The "Endangered" $P$. $[b]$.$b . waldroni occurs only in the high forests of the southern Côte d'Ivoire$ east of the Bandama River and in western Ghana. P. [b.] b. badius lives in Sierra Leone, Liberia, Guinea and Côte d'Ivoire. No population estimates are available for any subspecies, and numbers of waldroni and badius are thought to have declined throughout their ranges. All are highly arboreal and found in the high canopy. They inhabit a variety of forest types with badius and waldroni restricted to denser forests than temminckii, which can also be found in mangrove swamps, dry woodland or cultivated areas. Diets probably consist of mature and young leaves. The main threats are habitat destruction from logging activities and hunting. The temminckii form is found in at least four protected areas, while badius is protected only in the Gola Forest Reserves of Sierra Leone and Sapo National Park in Liberia. The waldroni form is found in two national parks in western Ghana. No specimens of any of the subspecies are known to be held in zoological collections. All subspecies are listed in Class B of the African Convention and in Appendix 2 of CITES. Information on the conservation status of each of the three subspecies is listed separately below.

Procolobus [badius] badius waldroni Hayman, 1936

DISTRIBUTION Found only in high forests in southern Côte d'Ivoire east of the Bandama River, and in western Ghana $(3,4,6)$.

POPULATION No estimates are available. Numbers probably have declined rapidly in this century. It was considered to be common in Bia National Park in 1974, but rare in the Nini-Souhien National Park and Ankasa Game Production Reserve in Ghana (3).

HABITAT AND ECOLOGY Inhabits high forest $(3,6,10)$. The only information on ecology and diets comes from Booth's analysis of stomach contents (4), which found leaves derived primarily from the main commercial timber spcies.

THREATS Habitat destruction and hunting are serious threats. Poaching for meat is endangering the fauna of Côte d'Ivoire (28). In Ghana, the majority of forest areas were cleared between 1900 and 1950 (9) for agriculture and cocoa plantations (3,10). By 1981 as little as $20 \%$ of forest areas were thought to remain intact, with charcoal production, logging and farming all encroaching on reserve areas $(10,18)$. All primates are intensively hunted for meat in Ghana $(3,10,18,19)$ and the subspecies has probably been locally exterminated in many parts of its range (3). The animals are highly conspicuous to hunters as a result of their vocalizations and are easy targets since they travel in single file (3).

CONSERVATION MEASURES Hunting of the subspecies needs to be banned or strictly controlled, both legally and practically. The remaining areas of habitat require protection. Conservation education is also required to alter attitudes to the animals. Studies of its distribution and status, especially in Côte d'Ivoire, are urgently needed. 
Hunting, capture or export of all wild animals is illegal in Côte d'lvoire (16) but enforcement of laws is needed. In Ghana, Wildlife Conservation Regulations protect the subspecies from hunting, trapping and export (16). Again, enforcement of existing regulations is necessary. The establishment of the Bia and Nini-Souhien National Parks in Ghana $(3,10,15)$ has protected some areas of forest habitats. Efforts are underway in Ghana to develop alternative sources of meat to hunted primates, to expand the economic potential of the National Parks through increased tourism, and to provide conservation education centres (10).

The subspecies is included in Class B of the African Convention (1969); it may be hunted, killed, captured or collected only under special authorization issued by the competent authority.

It is listed in Appendix 2 of the 1973 Convention on International Trade in Endangered Species of Wild Fauna and Flora, trade in it between acceding nations being therefore subject to regulation and monitoring of its effects.

CAPTIVE BREEDING Not known to occur in any zoological collections.

REMARKS For a description see (24).

TEMMINCK'S RED COLOBUS

RARE

Procolobus [badius] badius temminckii Kuhl, 1820

DISTRIBUTION This subspecies generally is coastal in distribution, and is found in southern Senegal, Gambia, Guinea-Bissau, and north-west Guinea $(25,31)$. The northernmost record is from Dalaba $\left(13^{\circ} 45^{\prime} N\right)(11)$. The eastern limits are uncertain (6).

POPULATION No overall population estimates exist. In Gambia's Abuko National Park, population densities range from 3.1-8.8 animals per ha (13). In Senegal 0.45-4.8 per ha have been recorded (11).

HABITAT AND ECOLOGY The subspecies lives in a range of forest types, from riverine forests, mangrove swamps, montane forest, to open woodland in savanna, and occasionally near cultivation $(6,29)$. They tend to be arboreal, but will come to the ground to forage or travel (13). Group size averages about 25 animals $(11,13,29)$, and may contain more than one adult male (29). Both males and females move between groups, although males attempting to enter a new group may be killed by other group members (29). Group composition varies over the short-term and may reflect a fission-fusion type of sociality $(13,29)$. The diet varies seasonally and consists primarily of young leaves, with seeds and fruits as major components $(13,29)$. Home range size has been recorded as between 9-20 ha (12). Predators, aside from humans, include Crocodiles and Pythons $(13,29)$.

THREATS None are specified. Habitat loss is probably a threat, especially in Guinea. Hunting may also be a problem. The protected habitat of the subspecies in Niokolo-Koba National Park, Senegal, may be threatened by the planned construction of a dam on the River Gambia which would cause extensive flooding (8). Fires (set by honey poachers) also destroy forests in the area of Niokolo-Koba (8).

CONSERVATION MEASURES In Gambia, the subspecies is abundant in Abuko National Park $(8,13,29)$. In Senegal, it is common in Basse Casamanse National Park $(8)$. There is a population of at least 600 in the Saloum Delta National Park (8). There is no information on its status in protected areas of Guinea or Guinea-Bissau. In Gambia, it has total legal protection under 1977 Wildlife Conservation Act against hunting, capture and trade, except in defence of crops or other property (16). In Senegal, it can only be trapped or exported under permit from the Water and 
Forest Service (16). More information is needed on the status and distribution of the subspecies in other parts of its range.

It is included in Class B of the African Convention (1969); it may be hunted, killed, captured or collected only under special authorization granted by the competent authority.

It is listed on Appendix 2 of the 1973 Convention on International Trade in Endangered Species of Wild Fauna and Flora, trade in it between acceding nations being therefore subject to regulation and monitoring of its effects.

CAPTIVE BREEDING None are known to be held in zoological collections.

REMARKS For photographs see (29).

\section{BAY COLOBUS}

VULNERABLE

Procolobus [badius] badius badius (Kerr, 1792)

DISTRIBUTION The subspecies is found in high forest areas of Sierra Leone, Liberia, Guinea and Côte d'Ivoire east of the Bandama River $(6,25,31)$. It may also occur on the west bank of the River Nzi in Côte d'Ivoire (5).

POPULATION No estimates are available, but numbers have declined thoughout its range during the past century. It was thought to be abundant in the Tai National Forest (Côte d'Ivoire) as late as $1978(3,30)$. In Sierra Leone, it is extremely rare (33) and in the Gola Forest Reserves very low densities are recorded from gallery forests (7). No information is available on populations in Liberia or Guinea.

HABITAT AND ECOLOGY The subspecies is found in primary and secondary high forests $(18,19)$ and in riverine or gallery forest $(6,21)$. It lives high in the canopy and group size averages from $25-40(10,31)$. It frequently associates in polyspecific groups with other Cercopithecus monkeys (10). The diet is thought to consist of leaves of leguminous plants, fruits and seeds (31).

THREATS Habitat loss and hunting continue to be major threats. In Sierra Leone, widespread forest clearance has reduced mature forest from $70 \%$ to less than $4 \%$ in the past century $(2,33,34)$. The Gola Forest Reserves in the south-east remain as important refuge areas for primates, but logging is continuing in these areas $(2,7,22,33)$. Government pest control programmes killed as many as 250000 primates between 1947-62 (17,21,32,33), driving many populations near extinction in the south-east $(21,33)$. Although the subspecies is not a crop pest, many were probably killed (21). In the Gola Forests, the subspecies appears to be especially vulnerable to logging disturbance in combination with hunting (7).

Liberian commercial hunters operating in Sierra Leone, in addition to local hunting, had a devastating effect on the primate populations $(21,33)$. Little information is available from Guinea, but hunting of primates for export of meat to Liberia may affect populations of Colobus Monkeys (27). In Liberia, logging activities increase the requirements for meat among the workers, open areas to hunters as a result of road building, and decrease cover as well as the availability of food species, which act to reduce primate populations $(21,35)$. Game meat is the most important source of protein and primates, including $P$. [b.] badius badius, are hunted extensively $(14,15,26,35)$. Hunting is virtually uncontrolled in Liberia and has led to the extinction of wildlife in some areas $(27,35)$. Little information is available from Côte d'Ivoire, but poaching of wildlife was thought to be a serious problem in $1963(28)$.

CONSERVATION MEASURES The hunting of the subspecies in all countries should be totally banned or strictly controlled, both legally and practically. The remaining areas of habitat 
urgently require protection and forestry needs to be managed for integration with conservation aims. Conservation education is urgently needed, as are further studies on the distribution and status of the subspecies. In Sierra Leone, the Gola Forest Reserves are the focus of projects integrating management of logging with conservation needs and controls on hunting $(7,22)$. Additional financial resources are needed to patrol existing reserves and effectively enforce hunting bans. Since 1982, the export of wildlife and wildlife products has been banned (16), and the effectiveness of these regulations needs to be monitored. The Sierra Leone Environment and Nature Conservation Association has provided public information on the Gola Forest $(2,7,33)$ and the new Conservation Society is helping to develop a national conservation strategy (22). Seven potential conservation areas in Liberia have been identified in a WWF/IUCN project carried out by Verschuren (35), and one of the areas, the 1085 sq.km Sapo National Park has been gazetted (27). The effectiveness of these conservation measures also needs to be monitored. In Côte d'Ivoire, the subspecies is protected in Tai National Park (20), and the hunting, capture or export of all wildlife is illegal, apart from "exceptional cases" when special licences may be granted (16). Enforcement of these laws is essential. No current information is available from Guinea.

The subspecies is included in Class B of the African Convention (1969); it may be hunted, killed, captured or collected only under authorization issued by the competent authority.

It is listed in Appendix 2 of the 1973 Convention on International Trade in Endangered Species of Wild Fauna and Flora, trade in it between acceding nations being therefore subject to regulation and monitoring of its effects.

CAPTIVE BREEDING Not known to occur in zoological gardens.

REMARKS For a description see (6).

\section{REFERENCES}

1. Anon. (1974). Oryx 12(5): 412.

2. Anon. (1983). Sierra Leone's last forests in serious danger. Oryx 17(4): 164-165.

3. Asibey, E.O.A. (1978). Primate conservation in Ghana. In: Chivers, D.J. and Lane-Petter, W. (Eds), Recent Advances in Primatology, Volume 2, Conservation. Academic Press, London.

4. Booth, A.H. (1956). The distribution of primates in the Gold Coast. Journal of the West African Science Association 2: 122-133.

5. Booth, A.H. (1958). The zoogeography of West African primates: A review. Bull. Inst. Fondam. Afr. Noire 20: 587-622.

6. Dandelot, P. (1974). Part 3: Order Primates. In: Meester, J. and Setzer, H.W. (Eds), (1971-77). The Mammals of Africa: An Identification Manual. Smithsonian Institution Press, Washington, D.C.

7. Davies, A.G. (1987). The Gola Forest Reserves, Sierra Leone: Wildlife Conservation and Forest Management. IUCN, Gland and Cambridge.

8. Dupuy, A.R. and Verschuren, J. (1977). Wildlife and parks in Senegal. Oryx 14(1): 36-46.

9. Foggie, A. and Hinds, J.H. (1951). In: Management and Conservation of Vegetation in Africa. Bulletin No. 41 of the Commonwealth Bureau of Pastures and Field Crops. Penglais Aberystwyth, Wales.

10. Gartlan, J.S. (1981). The forests and primates of Ghana. Prospects for protection and proposals for assistance. Unpublished report.

11. Gatinot, B.L. (1974). Précisions sur la répartition du Colobe Bai (Colobus badius temmincki Kuhl, 1820) et de la Mone de Campbell (Cercopithecus mona campbelli Waterhouse, 1838) en Sénégambie. Mammalia 38(4): 711-716.

12. Gatinot, B.L. (1975). Ecologie d'un Colobe Bai (Colobus badius temmincki Kuhn, 1820) dans un mileau marginal au Senegal. Ph.D thesis, Paris VI University.

13. Gunderson, V. (1977). Some observations on the ecology of Colobus badius temmincki, Abuko Nature Reserve, The Gambia, West Africa. Primates 18(2): 305-314.

14. Jeffrey, S. (1977). How Liberia uses wildlife. Oryx 14(2): 168-173. 
15. Jeffrey, S.M. (1975). Ghana's new forest national park. Oryx 13(1): 34-36.

16. Kavanagh, M. and Bennett, E L. (1984). A synopsis of legislation and the primate trade in habitat and user countries. In: Mack, D. and Mittermeier, R.A. (Eds), International Trade in Primates. TRAFFIC (U.S.A).

17. Mackenzie, F. (1952). Proceedings of the Zoological Society of London 122: 541.

18. Martin, C. (1976). Report of Project 1251. WWF Progress Report No. 102.

19. Mertz, A. (1981). In litt.

20. Monfort, A. and Monfort, N. (1973). Quelques observations sur les grands mammifères du Parc National de Tai (Côte d'Ivoire). La Terre et la Vie 27(4): 499-506

21 Oates, J.F. (1980). Report on a pilot study of Colobus verus and other forest monkeys in southern Sierra Leone with comments on conservation problems. Unpublished report.

22. Oates, J.F. (1983-1988). In litt.

23. Phillipson, J.R. (1978). Wildlife conservation and management in Sierra Leone. Special report to the Ministry of Agriculture and Forestry, Freetown.

24. Pocock, R.I. (1935). The external characters of a female Red Colobus Monkey. Proceedings of the Zoological Society of London: 939-944.

25. Rahm, U. (1970). Ecology, zoogeography and systematics of some African forest monkeys. In: Napier, J.R. and Napier, P.H. (Eds), Old World Monkeys. Academic Press, New York.

26. Roben, P. (1982). In litt.

27. Robinson, P.T. and Peal, A. (1981). Liberia's wildlife - the time for decision. ZooNooz 54(10): 7-21.

28. Roure, G. (1963). Conservation in the Ivory Coast. IUCN Publications New Series 1:309-310.

29. Starin, E.D. (1981). Monkey moves. Natural History 90(9): 36-43.

30. Struhsaker, T.T. (1972). Rain-forest conservation in Africa. Primates 13: 103-109.

31. Struhsaker, T.T. (1975). The Red Colobus Monkey. Chicago University Press, Chicago.

32. Tappen, N.C. (1964). Primate studies in Sierra Leone. Current Anthropology 5(4):339-340.

33. Teleki, G. (1980). Hunting and trapping wildlife in Sierra Leone: Aspects of exploitation and exportation. Unpublished report.

34. Teleki, G. and Baldwin, L. (1981). Sierra Leone's wildlife legacy: Options for survival. ZooNooz 54(10): 21-27.

35. Verschuren, J. (1983). Conservation of Tropical Rain Forest in Liberia. Recommendations for Wildlife Conservation and National Parks. Report of IUCN to the Government of Liberia. 
The IUCN Red Data Book

SUMMARY A West African group, containing three distinct subspecies all of which are "Endangered". This form of Red Colobus has a vcry restricted range and is known only from lowland evergreen forests of Cameroon $(P .[b$.$] p preussi), from a single reserve in Congo$ (Brazzaville) (P. [b.] p. bouvieri), and the island of Bioko (Equatorial Guinea) $(P .[b$.$] p. pennanti). No population estimates are available for the group as a whole, but all$ populations are thought to be extremely small. They inhabit dense forest or gallery forest and are probably arboreal folivores. The main threats to this group are hunting and habitat loss through logging. No individuals of any of the subspecies are known to be held in zoological gardens. They are listed in Class B of the African Convention and in Appendix 2 of CITES. Information concerning the subspecies in this group are presented separately below.

BOUVIER'S RED COLOBUS

ENDANGERED

Procolobus [badius] pennanti bouvieri (Rochebrune, 1887)

DISTRIBUTION The subspecies is endemic to Congo (Brazzaville), where it is known only from the Lefini Reserve $(4,13)$. It may occur at the confluence of the Oubangui and Zaire Rivers.

POPULATION No estimates, although numbers are thought to be perilously low (4).

HABITAT AND ECOLOGY Unknown. In the Lefini Reserve, 90\% of the vegetation is fire-induced grassland which is presumably not inhabited by the leaf-eating Colobus. The animals are probably restricted to the rich dense gallery forests fringing the River Lefini and its tributaries $(15,17)$.

THREATS All animals within the reserve are extensively hunted, especially in the vicinity of roads or along the rivers, where hunting from canoes is possible $(15,17)$. Both residents of villages near the reserve and commercial poachers supplying meat for towns hunt in the area $(15,17)$. Habitat loss as a result of proposals to dam the River Lefini might pose a problem, although a proposal to build a large dam which would have caused widespread flooding within the reserve has now been rejected (17).

CONSERVATION MEASURES The protected status of the Lefini area has expired (17) and it had not been officially gazetted by 1980 (15). Financial support and staffing levels are not adequate to protect the reserve area $(15,17)$ and outside support is essential $(15)$. Surveys of the distribution and status of the subspecies are urgently needed, and effective controls on hunting need to be implemented if the subspecies is to survive. Such protection may already be too late (4).

The subspecies is included in Class B of the African Convention (1969); it may hunted, killed, captured or collected only under special authorization granted by the relevant authority.

It is listed on Appendix 2 of the 1973 Convention on International Trade in Endangered Species of Wild Fauna and Flora, trade in it between acceding nations being therefore subject to regulation and monitoring of its effects. 
Threatened Primates of Africa

CAPTIVE BREEDING None are known to be held in zoological gardens.

REMARKS For description, see (13).

PENNANT'S RED COLOBUS

ENDANGERED

Procolobus [badius] pennanti pennanti Waterhouse, 1838

DISTRIBUTION This subspecies is endemic to the island of Bioko (Fernando Po) which is part of Equatorial Guinea $(4,8,11,12,16)$. The principal refuge appears to be the Caldera de San Carlos, in the island's interior (14). The crater is about $5 \mathrm{~km}$ in diameter with walls of up to $1000 \mathrm{~m}$ in height (14).

POPULATION No estimates are available. All primate species have been of conservation concern since Independence. No monkeys were observed in the forests near Moka in 1964 (10) and the survival of the subspecies was in doubt in 1984 (14).

HABITAT AND ECOLOGY Inhabits forest areas (4). No other information is known.

THREATS Hunting and habitat destruction have been historical threats, which have contributed to the significant loss of primate populations on the island $(2,10)$. A brief survey in 1985 found that wildlife was under less threat in the remote areas with soils incapable of sustaining year-round agriculture (3). Political and economic problems in the past 20 years have led to a reduction of human populations and their ability to exploit the island's natural resources. Firearms were confiscated in 1975 , and hunting pressure on primates was reduced. A recovery of primate populations is thought to have occurred (3).

CONSERVATION MEASURES No effective protection for the subspecies exists on Bioko (9) and surveys are urgently required to determine whether any significant populations remain and can be saved (11). The possibility of establishing the Caldera de San Carlos as a refuge area should be explored. With the return to stable political and economic conditions, integrated management of natural resources is a high development priority. Conservation education and management projects have been proposed, but require funding (3).

The subspecies is included in Class B of the African Convention (1969); it may be hunted, killed, captured or collected only under special authorization granted by the competent authority.

It is listed in Appendix 2 of the 1973 Convention on International Trade in Endangered Species of Wild Fauna and Flora, trade in it between acceding nations is therefore subject to regulation and monitoring of its effects.

CAPTIVE BREEDING None are known to be held in zoological gardens.

REMARKS For a description see (4).

Jorge Sabater Pi kindly commented on the draft data sheet. 
DISTRIBUTION Confined to northern Cameroon along the border with Nigeria. They are found south of the Ikon-Mamfe road $\left(4^{\circ} 24^{\prime}-5^{\circ} 36^{\prime} \mathrm{N}, 8^{\circ} 48^{\prime}-9^{\circ} 20^{\prime} \mathrm{E}\right)$ in a forest strip approximately $60 \mathrm{~km}$ wide and $120 \mathrm{~km}$ long (6). The majority of the population is now thought to be found in Korup National Park, with some animals in the Ejhagen Reserve to the north. They are not known to survive elsewhere (6). In the past their range was thought to have extended from the Cross River to the Sanaga River in coastal forests of Cameroon and in the lowland forests of south-east Nigeria $(4,16)$, where it is probably now extinct (6). The type specimen was collected by Matschie in the Barombi Mbo Forest some $60 \mathrm{~km}$ from the nearest present population (6). For a map see (16).

POPULATION The total number is unknown. Estimates based on observed group sizes of 30 animals in Korup National Park suggest that fewer than 8000 survive in all known inhabited areas (7).

HABITAT AND ECOLOGY They inhabit coastal lowland evergreen forest (6), typically in areas with rainfall over $1000 \mathrm{~mm}$ per month (16). They are exclusively arboreal and predominantly folivorous, depending on emergent trees for food and resting (6). Group size can be as large as 50 animals (16).

THREATS Habitat destruction is the main threat at present. Due to a dependence on high canopy trees, the animals are particularly vulnerable to logging or activities disrupting the canopy. Logging has taken place in part of the Ejhagen Reserve (6). Colobus monkeys are also easily hunted and commonly taken for food (6). Hunting has probably caused local extinctions, such as in the Barombi Mbo Forest (5).

CONSERVATION MEASURES Korup was gazetted as a national park in 1984 and contains the only protected viable population of the subspecies (1). The development of an infrastructure for the park is being financed and grants from the British Overseas Development Agency and World Wide Fund for Nature (U.K.). Extensive conservation education programmes were conducted in the vicinity of the Park between 1981-83 (17). It is illegal to hunt, trap or export the subspecies in Cameroon without a permit $(6,9)$.

The subspecies is included in Class B of the African Convention (1969); it may be hunted, killed, captured or collected only under special authorization granted by the competent authority.

The subspecies is listed in Appendix 2 of the 1973 Convention on International Trade in Endangered Species of Wild Fauna and Flora, trade in it between acceding nations being therefore subject to regulation and monitoring of its effects.

CAPTIVE BREEDING None are known to be held in zoological collections.

REMARKS For a description, see $(4,8)$.

\section{REFERENCES}

1. Agland, P.C. (1984). Pers. comm.

2. Anon. (1969). Threat to monkeys on Fernando Po. Oryx 10: 146-147.

3. Butynski, M. and Roster, S.H. (1986). Preliminary outlines for three conservation activities on Bioko Island (Fernando Po), Equatorial Guinea. Unpublished report.

4. Dandelot, P. (1974). Part 3: Order Primates. In: Meester, J. and Setzer, H.W. (Eds), (1971-1977). The Mammals of Africa: An Identification Manual. Smithsonian Institution Press, Washington D.C. 


\section{Threatened Primates of Africa}

5. Gartlan, J.S. (1975). The African coastal rain forest and its primates - threatened resources. In: Bermant, G. and Lindburg, D.G. (Eds), Primates Utilization and Conservation. John Wiley and Sons, New York.

6. Gartlan, J.S. (1977). In litt.

7. Gartlan, J.S. and Agland, P.C. (1980). A proposal for a program of rain-forest conservation and national park development in Cameroon, West-Central Africa. Unpublished report to the Gulf Oil Corporation.

8. Haltenorth, T, and Diller, H. (1980). A Field Guide to the Mammals of Africa including Madagascar. Collins, London. English Translation.

9. Kavanagh, M. and Bennett, E.L. (1984). A synopsis of legislation and the primate trade in habitat and user countries. In: Mack, D. and Mittermeier, R.A. (Eds), International Trade in Primates. TRAFFIC (U.S.A.).

10. Oates, J.F., (1977). The Guereza and Man: How Man has affected the distribution and abundance of Colobus guereza and other Black Colobus monkeys. In: Rainier, H.R.H. III and Bourne, G.H. (Eds), Primate Conservation. Academic Press, New York and London.

11. Oates, J.F., Gartlan, J.S. and Struhsaker, T.T. (1982). A framework for planning rain-forest primate conservation. International Primate Society Newsletter No. 1.

12. Parrot, J. (1981). Cameroon forest parks conservation education programme, report 1980/81. Unpublished report.

13. Rahm, U. (1970). Ecology, zoogeography and systematics of some African forest monkeys. In: Napier, J.R. and Napier, P.H. (Eds), Old World Monkeys. Academic Press, New York.

14. Sabater Pi, J. (1984). In litt.

15. Spinage, C.A. (1980). Parks and reserves in Congo Brazzaville. Oryx 15(3): 292-295.

16. Struhsaker, T.T. (1975). The Red Colobus Monkey. Chicago University Press, Chicago.

17. Verschuren, J. (1982). Republique Populaire de Congo. Relance de la conservation de la nature. Unpublished report. 
The IUCN Red Data Book

VULNERABLE

Procolobus [badius] rufomitratus Peters, 1879

Order PRIMATES

Family CERCOPITHECIDAE

SUMMARY The Eastern Red Colobus group is recognized as distinct from the western forms. Six subspecies are distinguished and occur in Central and East Africa where they inhabit a variety of forest habitats ranging from lowland and montane rain forests to swamp and gallery forests. Four of the subspecies are found in Eastern Zaire (tholloni, foai, ellioti, oustaleti), while the remaining two are found in Uganda and Tanzania (tephrosceles), and Kenya (rufomitratus). Of the four found in Zaire, the distributions and population sizes are basically unknown within the large forest blocks. Some are found in protected areas while others do not occur in any protected area. No threats are specified, but hunting is likely to be a problem in some areas. The two subspecies found further to the east occur in dense forests in Uganda and Tanzania, and in gallery forests in the Tana River area of Kenya. These subspecies are found in relatively low numbers and do occur in protected areas. The Kenyan subspecies, rufomitratus, is currently highly "Endangered" and may possibly become extinct in the near future. Tephrosceles is considered "Vulnerable" because of habitat loss due to pressures on forest areas from the increasing numbers of humans. None of the subspecies are known to be held in zoological gardens. All forms are listed in Class B of the African Convention and in Appendix 2 of CITES except the Tana River Red Colobus (rufomitratus) which is listed in Class A and in Appendix 1.

Information on the conservation status of the different forms is detailed below. Since little is known of the subspecies in Zaire, they are summarized together. The other two subspecies are presented separately.

\section{INSUFFICIENTLY KNOWN}

Procolobus [badius] ru fomitratus tholloni Milne Edwards, 1886

P. [b.] r. foai Pousargues, 1899

P. [b.] r. ellioti Dollman, 1909

P. [b.] r. oustaleti Trouessart, 1906

DISTRIBUTION All of the above four subspecies occur only in Zaire and principally in the east of the country. The tholloni form is found in the Salongo forest block where its range is between the Zaire and the Kasai-Sankuru Rivers $(5,22)$. The foai form is bounded by Lake Tanganyika on the east, but the western extent of its range is uncertain $(5,22)$. To the north and south, the Elila and Lukuga Rivers appear to limit its range. The ellioti form is found between the Zaire River in the west, the Aruwimi-Ituri River in the north and the Elila River in the south $(5,33)$. It was reported to occur in the Semliki Forest Reserve in Uganda in the 1950s (31), but its presence there is now unlikely (31). The oustaleti form is found in northern Zaire, probably only north of the Arumimi-Ituri River $(5,22)$. Its range extends from the Oubangui and Zaire Rivers in the west $(5)$ to Lake Albert and the Ituri River in the east $(5,22)$. One skin has been reported to orginate in Sudan (22), but presence outside Zaire has yet to be confirmed.

POPULATION No population estimates exist for any of the four subspecies.

HABITAT AND ECOLOGY The subspecies are found in a variety of habitats, from dense lowland or montane forest, to swamp forests and gallery forests $(5,22)$. No further information is available. In keeping with most Colobus Monkeys, they are probably folivorous (30). 
THREATS Specific threats are unknown since the status of the subspecies are so poorly known. It is likely however that hunting is a problem in some areas $(31,33)$ and deforestation may be a problem in the future (33).

CONSERVATION MEASURES Surveys are required to determine the distribution and conservation status of these subspecies. Protected areas such as the Salongo National Park may contain the tholloni form, while the ellioti form may be found in Kahuzi-Biega and Maiki National Parks. It is not known whether the other two subspecies occur in protected areas. Colobus monkeys are legally protected in Zaire, and can only be exported under special authorization of the Minister of Agriculture (11).

These primates are included in Class B of the African Convention (1969); and may be hunted, killed, captured or collected only under authorization issued by the competent authority.

They are also listed in Appendix 2 of the 1973 Convention on International Trade in Endangered Species of Wild Fauna and Flora, trade in them between acceding nations being therefore subject to regulation and monitoring of its effects.

CAPTIVE BREEDING None are known to be held in zoological gardens.

REMARKS For a description see (5).

\section{UGANDA RED COLOBUS}

VULNERABLE

\section{Procolobus [badius] ru fomitratus tephrosceles Elliot, 1907}

DISTRIBUTION This subspecies occurs in south-western Uganda and western Tanzania, possibly extending into Burundi and eastern Zaire $(5,22)$. The one population thought to be viable occurs in Kibale Forest in Uganda $(22,31)$. Tiny, patchy populations are known from areas immediately to the west of the Kibale Forest boundary and a narrow forest strip along the Mpanga River near the escarpment above Lake George. In Tanzania it is known from a small forest patch on the edge of the Bilharamula Game Reserve and from the Birigi Game Reserve (24). It is also found in various sites in the mountains on the edge of Lake Tanganyika $(4,24)$. Several populations in Tanzania are thought to have become extinct in the past 30 years (24). It is not known if te phrosceles currently occurs in Burundi, where it was thought to exist up to the late $1970 \mathrm{~s}(22,34)$. There is no confirmation of its reported presence in Zaire (5).

POPULATION The total population is probably in the low thousands. In those areas of the Kibale Forest where it is most common, densities average 297 animals per sq.km (30), but in other areas of the same forest it is much less abundant. Estimates for Tanzania suggested that small widely separated populations totalled less than 300 in $1981(23,24)$. Numbers have declined considerably thoughout its range in recent years as a result of deforestation $(25,30,31,34)$.

HABITAT AND ECOLOGY It is frequently found in relatively undisturbed mature rain forest (31), and also in gallery and montane forest $(5,10,21)$. Group size tends to be large, about 50 animals in good habitats such as Gombe, Mahale and Kibale $(4,21,32)$, and is around 25 in Mbizi (23). Groups are stable and multi-male, with females tending to migrate between groups (32). Over $80 \%$ of the diet is composed of leaves and leaf parts from many different tree species (31). Feeding and foraging occupy around $45 \%$ of time, with over $30 \%$ spent resting. Mean home range size in Kibale is 35 ha, with complete overlap between groups. Ranging patterns are determined by the location of foods, and to a lesser degree, the location of other groups $(9,29,32)$. Common predators include Crowned Hawk Eagles, Ste phanoetus coronatus (28) and Chimpanzees, Pan troglodytes (3). 
THREATS The main threat is habitat destruction. In Uganda, little natural forest remains outside forest reserves, and selective logging on a cyclical basis continues even within the reserves (31). Poisoning of "undesirable" non-timber species also negatively affects primate densities (31). Agricultural encroachment in the southern part of the Kibale Reserve is also a serious problem, which has not yet been dealt with by the government authorities (31). Timber poaching with a $200 \%$ return against the potential fines is a further cause of forest loss (31). Red Colobus appear to survive in lightly logged forests, as long as those tree species making up the majority of the diet are present (27). Hunting of primates does not appear to be a problem in Uganda.

In Tanzania, forest reserves were created during the colonial administration, but many of these were replanted with exotic species and therefore do not constitute a food source for the monkeys (25). Encroachment on reserves by cultivation and the illegal production of charcoal are major problems (24). Fires are a cause of habitat loss in some areas (25). However, the populations in national parks are under no threat at the moment, and those remaining in forest reserves appear to be reasonably safe (24). Hunting for meat or skins is a minor threat in some areas (10), but is not widespread (25).

CONSERVATION MEASURES With full practical and legal protection for the reserve areas containing the subspecies, it should survive. Conservation education is urgently required throughout its range to ensure public awareness of the problems facing the animals in forest habitats $(25,31,34)$. Surveys are needed to determine whether the subspecies is still present in Burundi.

Procolobus badius is fully protected by law in both Uganda and Tanzania $(11,26)$. It is found in the central area of the Kibale Forest Reserve, which is protected from all forms of human exploitation (31). With adequate enforcement, the reserve should protect a large population of the subspecies. In Tanzania, the subspecies is fully protected in Gombe and Mahale Mountains National Parks, and is present in some protected reserve areas (25). If the reserve areas receive increased levels of practical protection and the parks continue to receive adequate protection, the future of the animals should be secure.

The subspecies is included in Class B of the African Convention (1969); it may be hunted, killed, captured or collected only under authorization issued by the competent authority.

It is listed in Appendix 2 of the 1973 Convention on Trade in Endangered Species of Wild Fauna and Flora, trade in it between acceding nations being therefore subject to regulation and monitorng of its effects.

\section{CAPTIVE BREEDING Unknown.}

REMARKS For a description see (12,30).

\section{TANA RIVER RED COLOBUS}

\section{ENDANGERED}

\section{Procolobus [badius] ru fomitratus ru fomitratus Peters, 1879}

DISTRIBUTION The Tana River Red Colobus is endemic to small patches of gallery forest along the floodplains of the Tana River in Kenya $(1,5,6,7,12,15)$. The total known range is $52 \mathrm{~km}$ from Kipende in the north to Lango la Simba in the south, where the Lamu-Garsen road enters the Tana River floodplain $(1,14)$. Reports of its presence in the Sokoke-Arabuko Forest $100 \mathrm{~km}$ south of Garsen have never been confirmed and were probably due to misidentification (14). 
POPULATION A survey in 1985 suggested a total of 200-300 (13). This represents a drastic drop since 1975 when the estimate was between $1245-1700(14,15)$. In 1972 the total was 1860 (6). Most of the population is found in the northern half of its tiny range $(6,14,31)$.

HABITAT AND ECOLOGY The subspecies lives in small patches of gallery forest, often less than a few ha in size, which are seasonally innundated by the Tana River $(1,6,7,14)$. The gallery forest is made up of a mosaic of habitats, and the subspecies is found in areas closest to the river, in all areas dominated by Pachystela forests, in $70 \%$ of mixed species areas and in just over $50 \%$ of areas dominated by Barringtonia (14). Diet consists of young leaves (36\%) and fruit (25\%), with leaf buds (16\%), mature leaves (12\%) and flowers (6\%) making up the remainder. The diet is relatively restricted, with low diversity and concentrating on Ficus sycomorus (20). Just over $30 \%$ of time is spent feeding, and over $50 \%$ is inactive (19). Group size ranges between 12-20, with each group containing one or, at the most, two adult males (16). Each group travels about $600 \mathrm{~m}$ in a day within a home range of 9 ha, this is used as a function of the availability of young leaves (18). Adult and subadult females emigrate between groups, and group size can vary as a result throughout a year (16).

THREATS Habitat destruction was previously considered to be the major threat within a very restricted range, and hunting was not thought to be a problem $(1,2,7,17)$. The initial population declines were related to clearance of the gallery forest for agriculture, the loss of figs (Ficus) for canoe construction, fires set to enhance grass production on the surrounding floodplains, and habitat alteration from large herbivores. Changes in river management affecting regeneration in the forests on the floodplains was expected to be a problem $(13,15)$.

The 1985 resurvey has highlighted that the decline in the Colobus population is a result of changes in forest regeneration (13). Changes in the water table due to the construction of a dam downstream from the Tana River Reserve and the diversion of water to the Bura Rice Irrigation Scheme appears to have drastically slowed the rate of vegetation, and especially tree, regrowth. The senescence of those mature trees forming the staple diet of the Colobus has had marked effects on a selective feeder that is unable to utilize secondary forest $(13,20)$.

CONSERVATION MEASURES Areas of the gallery forest along the banks of the Tana River were gazetted as a Primate Reserve in 1976 (2). The forest is in discontinuous patches and totals only 12 sq.km out of the 170 sq.km reserve $(2,31)$; the status of the reserve allows for some mixed use rather than complete protection (13). Only $50-60 \%$ of the remaining population of Colobus is protected in the reserve $(13,31)$.

A project is underway which aims to investigate the causes of change in patterns of tree regeneration in the reserve and will implement experimental planting (13). Additional financial support is required for the project. In the light of the recent catastrophic decline in numbers of this Colobus monkey, it may be too late to save it from extinction. However the area also contains the "Endangered" subspecies of Mangabey, Cercocebus galeritus galeritus, as well as other more common primates and the project is therefore also necessary for their future wellbeing..

$R u$ fomitratus has legal protection in Kenya and cannot be exported.

It is included in Class A of the African Convention (1969); it may be hunted, killed, captured or collected only on the authorization of the highest competent authority if required in the national interest or for scientific purposes.

It is listed on Appendix 1 of the 1973 Convention on International Trade in Endangered Species of Wild Fauna and Flora, trade in it between acceding nations is subject to severe restrictions and trade for primarily commercial purposes is banned.

CAPTIVE BREEDING None are known to be held in zoological collections.

REMARKS For a description, see (12). 


\section{REFERENCES}

1. Andrews, P., Groves, C.P. and Horne, J.F.M. (1975). Ecology of the lower Tana River flood plain (Kenya). Journal of the East African Natural History Society National Museum 151: 1-31.

2. Anon. (1976). Kenyans demand new reserves. Oryx 13(3): 232.

3. Busse, C.D. (1977). Chimpanzee predation as a possible factor in evolution of Red Colobus Monkey social organization. Evolution 31: 907-911.

4. Clutton-Brock, T.H. (1972). Feeding and ranging behaviour of the Colobus Monkey. Ph.D thesis, University of Cambridge.

5. Dandelot, P. (1974). Part 3: Order Primates. In: Meester, J. and Setzer, H.W. (Eds), (1971-1977). The Mammals of Africa: An Identification Manual. Smithsonian Institution Press, Washington, D.C.

6. Groves, C.P., Andrews, P. and Horne, J.F.M. (1974). Tana River Colobus and Mangabey. Oryx 12(5): 565-575.

7. Homewood, K.M. (1975). Can the Tana Mangabey survive? Oryx 13(1): 53-59.

8. Hughes, F.M.R. (1984). A comment on the impact of development schemes on the floodplain forests of the Tana River of Kenya. The Geographical Journal 150(2): 230-244.

9. Isabell, L.A. (1983). Daily ranging behavior of Red Colobus Colobus badius te phrosceles) in the Kibale Forest, Uganda. Folia Primatologica 41: 34-48.

10. Kano, T. (1971). Distribution of primates on the eastern shore of Lake Tanganyika. Primates 12: 281-304.

11. Kavanagh, M. and Bennett, E.L. (1984). A synopsis of legislation and the primate trade in habitat and user countries. In: Mack, D. and Mittermeier, R.A. (Eds), International Trade in Primates. TRAFFIC (U.S.A.).

12. Kingdon, J. (1971). East African Mammals, Volume 1. Academic Press, New York.

13. Marsh, C.W. (1985). A Resurvey of Tana River Primates. Report to Institute of Primate Research, Kenya and Department of Wildlife Conservation and Management.

14. Marsh, C.W. (1978). Ecology and social organisation of the Tana River Red Colobus, Colobus badius ru fomitratus. Ph.D thesis, University of Bristol.

15. Marsh, C.W. (1978). Problems of primate conservation in a patchy environment along the lower Tana River, Kenya. In: Chivers, D.J. and Lane-Petter, W. (Eds), Recent Advances in Primatology, Vol. 2. Conservation. Academic Press, London and New York.

16. Marsh, C.W. (1979). Comparative aspects of social organization in the Tana River Red Colobus, Colobus badius rufomitratus. Z. Tier psychol. 51: 337-362

17. Marsh, C.W. (1980). Primates and economic development on the Tana River, Kenya: The monkeys in the works. In: Furtado, J.I. (Ed.), Tropical Ecology and Develo pment: Tropical Ecology. International Society of Tropical Ecology.

18. Marsh, C.W. (1981). Ranging behaviour and its relation to diet selection in Tana River Red Colobus (Colobus badius rufomitratus). Journal of Zoology 195: $473-492$

19. Marsh, C.W. (1981). Time budget of Tana River Red Colobus. Folia Primatologica 35: 30-50.

20. Marsh, C.W. (1981). Diet choice among Red Colobus (Colobus badius rufomitratus) on the Tana River, Kenya. Folia Primatologica 35: 147-216.

21. Nishida, T. (1972). A note on the ecology of the Red Colobus Monkeys (Colobus badius te phrosceles) living in the Mahale Mountains. Primates 13(1): 57-64.

22. Rahm, U. (1970). Ecology, zoogeography and systematics of some African forest monkeys. In: Napier, J.R. and Napier, P.H. (Eds), Old World Monkeys. Academic Press, New York.

23. Rogers W.A., Struhsaker, T.T., and West, C.C. (1984). Observations on the Red Colobus (Colobus badius te phroscles) of Mbizi Forest, south-west Tanzania. African Journal of Ecology 22(3): 187-194.

24. Rogers, W.A. (1981). The distribution and conservation status of Colobus monkeys in Tanzania. Primates 22: 33-45. 
25. Rogers, W.A. (1983). The conservation of primates in Tanzania. In: Harper, D. (Ed.), Proceedings of the Symposium on the Conservation of Primates and their Habitats. Volume 1, Primate Conservation in the Wild. Department of Adult Education, University of Leicester.

26. Rogers, W.A. and Homewood, K.M. (1980). In litt.

27. Skorupa, J.P. (1987). Responses of rainforest primates to selective logging in Kibale Forest, Uganda: A summary report. In: Benirschke, K. (Ed.), Primates: The Road to Self-Sustaining Po pulations. Springer-Verlag, London.

28. Skorupa, J.P. (1983). Pers. comm.

29. Struhsaker, T.T. (1974). Correlates of ranging behavior in a group of Red Colobus Monkeys (Colobus badius te phrosceles). American Zoologist 14: 177-184.

30. Struhsaker, T.T. (1975). The Red Colobus Monkey. Chicago University Press, Chicago.

31. Struhsaker, T.T. (1981). Forest and primate conservation in East Africa. African Journal of Ecology 19: 99-114.

32. Struhsaker, T.T. and Leland, L. (1979). Socioecology of five sympatric monkey species in the Kibale Forest, Uganda. In: Rosenblatt, J.S., Hinde, R.A., Beer, C. and Busnel, M.C. (Eds), Advances in the Study of Behavior, Volume 9. Academic Press, New York.

33. Verschuren, J. (1975). Wildlife in Zaire. Oryx 13(1): 25-33.

34. Verschuren, J. (1978). Burundi and wildlife: Problems of an overcrowded country. Oryx 14(3): 237-240. 
The IUCN Red Data Book

UHEHE, GORDON'S Or IRINGA RED COLOBUS

ENDANGERED

Procolobus [badius] gordonorum (Matschie, 1900)

Order PRIMATES

Family CERCOPITHECIDAE

SUMMARY The Uhehe Red Colobus is endemic to Tanzania where it is found only in forests on the Uzungwa Mountains. It is extremely rare with a patchy distribution. The most viable population is found in the Magombero Forest which has been bisected by the Tanzania-Zambia railway, and is threatened by further habitat disturbance. Some populations have been virtually eliminated by hunting. Recommended conservation measures include increased protection for reserve areas and reduction of habitat disturbance both within and outside reserves. No individuals are known to be held in zoological collections. The taxon is listed in Class A of the African Convention and in Appendix 2 of CITES.

DISTRIBUTION This type of Red Colobus is found only in south central Tanzania and is restricted to the southern and eastern slopes of the Uzungwa Mountains from Chita eastwards to Msolwa $(3,5,6,7,8)$. They often occur in isolated groups in forest patches (4). The most northerly population is isolated in the Magombero Forest Reserve $\left(3^{\circ} 47^{\prime} \mathrm{S}, 37^{\circ} 0^{\prime} \mathrm{E}\right)$ and adjacent riverine forest (7).

POPULATION No overall estimates exist, but it is generally extremely rare $(4,6,7,8)$. A 1977 survey estimated the minimum population in the $11 \mathrm{sq} . \mathrm{km}$ Magombero Forest Reserve to be 150 animals $(6,8)$, and a 1979 survey suggested a total population of $450(4,5)$. The age structure suggested a healthy population in both surveys $(5,6,8)$. Densities in the Uzungwa Mountain forests are lower, with no more than 200 groups in 800 sq.km of forest (4). Since many of these groups are isolated in small forest patches, their survival is doubtful (4).

HABITAT AND ECOLOGY A high forest primate, living in riverine and montane forest patches at elevations between 550-6000 m (4,5,7). Group sizes in Magombero average about 25 animals with one or more adult males $(5,6,8)$, but smaller groups of $4-6$ animals are known from the Uzungwa forests (3). It is not known if the observed groups are typical, or the result of forest disturbance (8). Groups are frequently found in polyspecific associations with Forest Cercopithecines in Magombero $(5,8)$, or in association with Black-and-White Colobus monkeys in the Uzungwas (3). The diet is poorly known and a few incidental feeding observations suggest that young leaves primarily from Albizia gumnifera or leaf parts are eaten (3) along with some fruits (8).

THREATS Habitat loss within a restricted range is the most serious threat and hunting is a problem in some areas. The largest population is found in the Magombero Forest Reserve, which has been incorporated into the Selous Game Reserve. The forest rezerve is severely threatened by timber removal and extensive agricultural encroachment on all but the southern edges $(4,5,6,7,8)$. The Tanzania-Zambia Railway, which was constructed between $1972-75$, runs through the reserve for $6 \mathrm{~km}$ and completely bisects it. The railway embankments, flanked by large ditches and cleared land on all sides, form a $60-70 \mathrm{~m}$ wide barrier to monkey dispersal, effectively splitting them into a northern and southern population $(4,5,6,7,8)$. The presence of the railway has also facilitated agricultural encroachment on the reserve and increased the number of bush fires. Fires appear to be responsible for the decline in size of the reserve from 15 sq.km in 1955 to less than 11 sq.km by 1979 (5). The development of rubber plantations in the area poses an additional threat (5). In the Mwanihana Forest Reserve, agricultural encroachment is again the major source of habitat alteration (6). Hunting is a problem in the Uzungwa highlands, where the Wahehe people consider its meat a delicacy (5). Some populations have been virtually eliminated in these areas (5). Hunting is less common in the Magombero area.

CONSERVATION MEASURES $P$. badius has the status of "Presidential Game" in Tanzania, and is therefore totally protected by law (4). Certificates are required to possess skins or any other part (4) and it can only be exported under permit (1). Enforcement of these laws is 
essential in areas where the animals are hunted. Surveys of the distribution and status of $P$. [b.] gordonorum within its range are required. The remaining areas of habitat urgently need protection. Recommendations include: i) The creation of firebreaks along the forest edge in Magombero to prevent the further incursion of fires; ii) The removal of illegal agricultural encroachment in all reserve areas and the enforcement of legal protection; iii) Remaining areas of habitat containing viable populations should be strictly protected $(4,5,6,7,8)$.

The species is included in Class A of the African Convention (1969); it may be hunted, killed, captured or collected only on the authorization of the highest competent authority, if required in the national interest or for scientific purposes.

It is listed on Appendix 2 of the 1973 Convention on International Trade in Endangered Species of Wild Fauna and Flora, trade in it between acceding nations being therefore subject to regulation and monitoring of its effects.

CAPTIVE BREEDING None are known to be held in zoological gardens at the present time.

REMARKS For description see $(2,8)$.

\section{REFERENCES}

1. Kavanagh, M. and Bennett, E.L. (1984). A synopsis of legislation and the primate trade in habitat and user countries. In: Mack, D. and Mittermeier, R.A. (Eds), International Trade in Primates. TRAFFIC (U.S.A.).

2. Kingdon, J. (1971). East African Mammals, Volume 1. Academic Press, New York.

3. Lovett, J.C. (1983). Tanzania: Habitat evaluation in Uzungwa and Usambara Mountains. Interim Report to WWF/IUCN.

4. Rodgers, W.A. and Homewood, K.M. (1980). In litt.

5. Rodgers, W.A., Homewood, K.M. and Hall, J.B. (1980). The railway and a rare Colobus monkey. Oryx 15(5): 491-495.

6. Struhsaker, T.T. (1977). Report on a survey of rare Colobus monkeys in the Magombero Forest Reserve - Lukoga, Msolwa and Pala Ulanga Forest Reserve, Madizini, Tanzania. Unpublished report.

7. Struhsaker, T.T. (1981). Forest and primate conservation in East Africa. African Journal of Ecology 19: 99-114.

8. Struhsaker, T.T. and Leland, L. (1980). Observations on two rare and endangered populations of Red Colobus monkeys in East Africa: Colobus badius gordonorum and Colobus badius kirkii. African Journal of Ecology 18: 191-216. 
The IUCN Red Data Book

ENDANGERED

Procolobus [badius] kirkii Gray, 1868

Order

PRIMATES

Family CERCOPITHECIDAE

SUMMARY The Zanzibar Red Colobus is endemic to Zanzibar Island off the coast of Tanzania. High densities are found only in four forest areas on the island. It lives in relatively large multi-male groups with overlapping home ranges. Habitat destruction within its very restricted range is a major threat and no populations are effectively protected. Full legal and practical protection of Jozani Forest Reserve and remaining areas of habitat are required if the taxon is to survive. None are known to be held in captivity. The animal is listed in Class $\mathrm{A}$ of the African Convention and in Appendix 1 of CITES.

DISTRIBUTION Endemic to the 1600 sq.km Zanzibar Island, Tanzania $(2,4,7)$. It is now known to occur at very low densities throughout the island in small, isolated forest patches, while higher densities are found only in four southern forests: Jozani Forest, Muungwi Forest, the Muyuni coastal strip and Uzi Island (11). Small populations of translocated animals are found at Masingini, Kichwele, and on Pemba Island $75 \mathrm{~km}$ north-east of Zanzibar $(8,11)$.

POPULATION The total population was estimated in 1981 to be almost 1500 animals in 75 groups (11). The Jozani population was thought to contain 235 animals (11); this population appears to be relatively stable, since it was estimated at 200 in 1964 (1) and 155 in 1972 (3). The ratio of one infant for every two adults in 1981 is further evidence that the Jozani population is healthy (11). The other significant populations are Muungwi with about 200 animals, Muyuni coastal strip with 350 animals and Uzi Island with 300 animals (11).

HABITAT AND ECOLOGY The monkeys live primarily in areas of ground water and swamp forest, and scrub forest on coral rag. They are aiso found in mangrove swamp $(9,11,12)$. Diets have not been described in detail. Groups tend to be large, containing 35 animals with at least two adult males $(11,12)$. Separate groups are often found in close proximity to each other, are relatively tolerant and home ranges overlap extensively $(5,12)$. Vocalizations are distinct from those of other Red Colobus and have been described by Struhsaker and Leland (12).

THREATS Habitat destruction is the primary threat (12). All areas where the animals occur lack legal protection and are selectively logged (11). Timber felling, charcoal production, clearance for cultivation, and bush burning to facilitate hunting of pigs and duikers contribute to habitat loss (12). The Jozani Forest is threatened by logging; however if the current rate of exploitation is not increased, the Colobus population there should survive (11,12). Animals are occasionally shot for food, sport, or as a supposed crop pest, but habitat loss is a more serious threat (12).

CONSERVATION MEASURES Under the Wildlife Conservation Act, $P$. [b.] kirkii is fully protected (10), and $P$. badius has the status of "Presidential Game" (9); posession of any part of the animal is illegal without a certificate of ownership and live capture requires permits from the Ministry of Agriculture. The 31 sq.km Jozani Forest was gazetted as a Forest Reserve in 1960. However, to ensure the survival of the Colobus, its status should be upgraded to that of a National Park and human exploitation should be prohibited $(11,12)$. Further recommendations (12) include the extension of the boundaries to include (i) mangrove swamp to the north; (ii) more areas of evergreen scrub in the east; (iii) Pete Forest to the south. Reforestation of the area between the reserve and the highway in the south would enhance the movement of animals between Jozani and Pete Forests (12). Other areas with major populations, such as the Muyuni coastal strip and the southern part of Uzi Island, should be gazetted as national parks. Since none of the existing populations are effectively protected, between 1979 and 1981, 36 animals were translocated into "safer" forest reserves at Masinini and Kichweli (11). 
The taxon is included in Class A of the African Convention (1969); it may be hunted, killed, captured or collected only on the authorization of the highest competent authority if required in the national interest or for scientific purposes.

It is listed on Appendix 1 of the 1973 Convention on International Trade in Endangered Species of Wild Fauna and Flora, trade in it between acceding nations is subject to severe restrictions and trade for primarily commercial purposes is banned.

CAPTIVE BREEDING None are known to be held in captivity. Nine $P$. [b]. kirkii were kept in captivity by the Tanzanian authorities for educational display to the public during a holiday period. After two months all the animals were released (12).

REMARKS For a description, see $(2,12)$.

\section{REFERENCES}

1. Grimwood, I.R. (1964). In litt.

2. Kingdon, J. (1971). East African Mammals, Volume 1. Academic Press, New York.

3. Kingston, T.J. et al. (1974). The Oxford Expedition to Zanzibar 1972. Oxford University Exploration Club Bulletin 21: 156-188.

4. Dandelot, P. (1974). Part 3: Order Primates. In: Meester, J. and Setzer, H.W. (Eds), (1971-77). The Mammals of Africa: An Identification Manual. Smithsonian Institution Press, Washington D.C.

5. Mturi, F. (1983). In litt.

6. Oates, J.F., Gartlan, J.S. and Struhsaker, T.T. (1982). A framework for planning rain-forest primate conservation. International Primate Society Newsletter No 1.

7. Rahm, U. (1970). Ecology, zoogeography and systematics of some African forest monkeys. In: Napier, J.R. and Napier, P.H. (Eds), Old World Monkeys. Academic Press, New York. Pp. 591-626.

8. Rodgers, W.A. (1977). In litt.

9. $\quad$ Rodgers, W.A. (1980). In litt.

10. Rodgers, W.A. (1983). The conservation of primates in Tanzania. In: Harper, D. (Ed.), Proceedings of the Symposium on the Conservation of Primates and their Habitats, Volume 1, Primate Conservation in the Wild. Department of Adult Education, University of Leicester.

11. Silkilwasha, F. (1981). The distribution and conservation status of the Zanzibar Red Colobus. African Journal of Ecology 19: 187-194.

12. Struhsaker, T.T. and Leland, L. (1980). Observations on two rare and endangered populations of Red Colobus Monkeys in East Africa: Colobus badius gordonorum and Colobus badius kirkii. African Journal of Ecology 18: 191-216. 
The IUCN Red Data Book

OLIVE COLOBUS or VAN BENEDEN'S COLOBUS

RARE

Procolobus verus Van Beneden, 1838

Order PRIMATES

Family CERCOPITHECIDAE

SUMMARY The Olive Colobus inhabits dense vegetation in the forest zone stretching from Sierra Leone to Nigeria. No population estimates are available; the species is generally rare but locally numerous. While it is hunted occasionally, its cryptic behaviour may make it less vulnerable than other forest primates. Habitat destruction is the primary threat, but the species can live in riverine as well as dense forest. Remaining areas of habitat need protection and hunting should be controlled, in conjunction with conservation education programmes. Further information on distribution and status is needed. Not known to be held in captivity. The species is listed in Class A of the African Convention and in Appendix 2 of CITES.

DISTRIBUTION The species occurs in Sierra Leone, Guinea, Côte d'Ivoire, Ghana $(5,6,38)$, extending into Nigeria as far as Ayangba region in Benue State (21) and along the Okura River (27), both east of the Niger River. Its distribution in Nigeria may be even more widespread, since Oates reports that hunters have described animals resembling $P$. verus from the Niger Delta (25). While it presently does not occur in Benin, early specimens in the Berlin Museum were collected in Togo adjacent to the border with Ghana (25). The north-western limit in Sierra Leone is unclear; Hill (12) and Wilkinson (37) place it at $10^{\circ} \mathrm{N}$, close to the northern border, while according to Jones (15) and Oates (26), it is found only in the most southern areas of the country.

POPULATION No estimates are available. Due to its cryptic behaviour and poor visibility within its dense habitats, censuses are difficult to carry out $(5,12,14)$. Although rare throughout its range, the species can be locally abundant.

HABITAT AND ECOLOGY It is found primarily in rain forest, especially in the thick lower layers of high canopy forests and the dense growth around tree falls. It is also present in swamps, riverine forest and abandoned cultivation $(5,6,8,14,26,32)$. The animals are diurnal and largely arboreal, being very infrequentiy observed on the ground (25). They are shy, quiet, elusive and cryptic $(5,14,26,28,32)$. The diet consists primarily of young leaves $(5,17,26)$, and includes small amounts of fruits and seeds (25). Feeding and travel tend to occur in the lower layers of the canopy, usually below $12 \mathrm{~m}$. They commonly form polyspecific associations with other Cerco pithecus species $(5,10,26)$, such as $C$. diana, and will then travel at the higher canopy levels common to the other species (25). Group size averages 10 animals, and ranges from 6-20 (5), with members of a group being highly dispersed (25). Females have conspicuous perineal swellings around the time of ovulation $(5,12,26)$ and are very unusual in transporting young infants by carrying them in the mouth $(5,26)$.

THREATS No threats have been specified, although loss of habitat is undoubtedly the major threat. In comparison to the larger Colobus monkeys, $P$. verus may be less frequently hunted as it is smaller, difficult to locate, and some people say its flesh causes digestive disorders (25). Threats to the species are presented by nation.

Sierra Leone Massive deforestation over the past 200 years has resulted in the decline of the mature forest from $70 \%$ to less than $4 \%$ by $1980(2,3,4,35)$. Of the remaining forests, $65 \%$ was either being cut or under long-term concession to timber companies in 1980 (34). These forests now comprise the Gola Forest Reserves (7) in the south-east of the country; much of this area has already been logged $(2,25)$ and small areas have been planted with Eucalyptus which is unpalatable to primates (34). However, $P$. verus may be less affected than other primates since it can survive in the relatively less modified riverine forest habitats (26). Government pest control programmes between $1947-1962$ killed some 250000 primates $(19,26,33,34)$. Many $P$. verus were probably killed even though they are not crop pests (26). They may be hunted locally (26), but are not taken for the pet trade since they are difficult to keep in captivity (25). 
Guinea No specific information is available on the extent of forest loss or hunting pressure on the species. Liberian hunters operating in Guinea export bushmeat (29), this could include some $P$. verus.

Liberia Although some $50 \%$ of the country was still covered by primary or mature secondary forests in 1979, logging concessions are widely held (36). Logging and supporting developments open up forest areas to agriculturalists and hunters (36). Game meat is the primary source of protein in people's diets, and all primates are hunted extensively $(13,14,18,28,36)$. Such hunting is almost uncontrolled and has reduced wildlife numbers to the point of extinction in some regions $(29,36)$.

Côte d'Ivoire No information on the threats to the species have been obtained.

Ghana Over $80 \%$ of the forest has been lost to agriculture and cocoa plantations $(4,9,11)$, with felling for charcoal at the forest edges eroding what remains (11). Logging, farming and hunting occur illegally in some forest reserves $(11,20)$, and primates (including $P$. verus) are hunted intensively for food $(3,4,11,20,22)$.

Nigeria In the area along the Okura River where $P$. verus have been observed, the forest appears to be relatively undisturbed (27). Agricultural and economic development to meet the needs of an expanding human population appear to be placing severe pressures on remaining forest areas, including logging within reserves (27).

CONSERVATION MEASURES Remaining areas of habitat require protection, and hunting of Olive Colobus needs to be strictly controlled both legally and practically in all nations. Conservation education is urgently required to alert local residents to the extent of damage done by hunting and encroachment on forested areas. Further studies on the distribution and abundance of the species are necessary.

Sierra Leone Although the framework for habitat protection and species preservation exists under the Wildlife Conservation Act of 1972, inadequate funding and staffing has reduced the effectiveness of enforcement (34). The wording of the Act in regard to $P$. verus is ambiguous and does not appear to be enforced (25). The Gola Forest Reserves, within the range of $P$. verus, have been established as protected areas allowing for selective logging in combination with areas of complete protection and where hunting of wildlife is banned $(7,25)$. The $12 \mathrm{sq} . \mathrm{km}$ Tiwai Island, with a diverse primate community, has become a conservation area $(7,26)$. Since 1982 , the export of all wildlife and wildlife products has been banned (16); the effectiveness of this ban on controlling the Liberian trade is unknown. Conservation education, to make people aware of the negative impact of hunting on wildlife $(34,35)$, is underway in the area of the Gola Forest Reserves $(2,7,34)$.

Guinea No legislation protecting primates appears to exist. The presence of $P$. verus in protected areas is unknown.

Liberia Potential conservation areas were identified in 1979, and one of the seven proposed reserve areas $(29,36)$ - Sapo National Park - has been gazetted. The abundance of $P$. verus within this 1085 sq.km area of undisturbed rain forest is as yet unknown. Hunting regulations were established 1982 (28) and exports of primates are illegal (16). The effectiveness of these laws needs to be monitored. Conservation information has been provided to the public by the Forestry Development Authority to increase awareness of the need to manage and protect forests, flora and fauna $(29,36)$.

Côte d'Ivoire Olive Colobus occur within the 3500 sq.km Tai National Park (23). The hunting, capture and export of all wildlife is illegal apart from "exceptional cases" when special licences may be granted (16). The effectiveness of these laws has not been assessed.

Ghana Two national parks, Bia and Nini-Souhien, have been gazetted and extensions of their area have been suggested $(4,11,14)$. Schemes to develop alternative sources of protein to bushmeat have been implemented, and increasing tourism to the high forest national parks has been proposed as a way of generating additional revenue to sustain the parks $(4,11)$. 
Conservation education for primary and secondary students has been suggested as critical to changing public attitudes to wildlife conservation (11). P. verus is totally protected from hunting, trapping and export by Wildlife Conservation Regulations of 1971 (16). It is also illegal to hunt, shoot or set traps or snares in any forest reserve; penalties for infringement include fines and up to ten years imprisonment for a second offence (1). These laws should be enforced.

Nigeria No information is available on the occurrence of $P$. verus in protected areas. A survey is needed to determine distribution and status and to recommend appropriate conservation measures.

The species is included in Class A of the African Convention (1969); it may be hunted, killed, captured or collected only on the authorization of the highest competent authority, if required in the national interest or for scientific purposes.

It is listed on Appendix 2 of the 1973 Convention on International Trade in Endangered Species of Wild Fauna and Flora, trade in it between acceding nations being therefore subject to regulation and monitoring of its effects.

CAPTIVE BREEDING No information. They are apparently difficult to keep in captivity (25).

REMARKS For a description see (12). It has often been placed in the genus Colobus, but has also been considered to be distinct and is now grouped with the Red Colobus under its original name of Procolobus. No subspecies are recognized $(5,24)$.

\section{REFERENCES}

1. Anon. (1974). Oryx 12(5): 413.

2. Anon. (1983). Sierra Leone's last forest in serious danger. Oryx 17(4): 164-165.

3. Asibey, E.O.A. (1974). Wildlife as a source of protein in Africa south of the Sahara. Biological Conservation 6(1): 32-39.

4. Asibey, E.O.A. (1978). Primate conservation in Ghana. In: Chivers, D.J. and Lane-Petter, W. (Eds), Recent Advances in Primatology, Volume 2, Conservation.

Academic Press, London.

5. Booth, A.H. (1957). Observations on the natural history of the Olive Colobus Monkey Procolobus verus Van Beneden. Proceedings of the Zoological Society of London 129: 421-430.

6. Dandelot, P. (1974). Part 3: Order Primates. In: Meester, J. and Setzer, H.W. (Eds), (1971-77). The Mammals of Africa: An Identification Manual. Smithsonian Institution Press, Washington, D.C.

7. Davies, A.G. (1987). The Gola Forest Reserves, Sierra Leone: Wildlife Conservation and Forest Management. IUCN, Gland and Cambridge.

8. Dekeyser, P.L. (1955). Les Mammifères de l'A frique Noire Française. I.F.A.N., Dakar.

9. Foggie, A. and Hinds, J.H. (1951). In: Management and Conservation of Vegetation in Africa. Bulletin No. 41 of the Commonwealth Bureau of Pastures and Field Crops. Penglais, Aberystwyth, Wales.

10. Galat, G. (1978). Comparaison de l'abondance relative et des assocations plurispecifiques des Primates diurnes de deux zones du Parc National de Tai, Côte d'Ivoire. ORSTOM, Abidjan.

11. Gartlan, J.S. (1981). The forests and primates of Ghana. Prospects for protection and proposals for assistance. Unpublished report.

12. Hill, W.C.O. (1952). The external and visceral anatomy of the Olive Colobus Monkey (Procolobus verus). Proceedings of the Zoological Society of London 122: 127-186.

13. Jeffrey, S. (1977). How Liberia uses wildlife. Oryx 14(2): 168-173.

14. Jeffrey, S.M. (1975). Ghana's new forest national park. Oryx 13(1): 34-36.

15. Jones, T.S. (1950). Notes on the monkeys of Sierra Leone. Sierra Leone Agriculture Notes 22. Department of Agriculture, Sierra Leone.

16. Kavanagh. M. and Bennett, E.L. (1984). A synopsis of legislation and the primate trade in habitat and user countries. In: Mack, D. and Mittermeier, R.A. (Eds), International Trade in Primates. TRAFFIC (U.S.A.). 
17. Kuhn, H.-J. (1964). Zur Kenntnis von Bau und Funktion des Magens der Schlankaffen (Colobinae). Folia Primatologica 2: 193-221.

18. Leutenegger, W. (1976). Metric variability in the anterior dentition of African colobines. American Journal of Physical Anthro pology 45: 45-52.

19. Mackenzie, A.F. (1952). Proceedings of the Zoological Society of London 122: 541.

20. Martin, C. (1976). Report of Project 1251. WWF Progress Re port 102.

21. Menzies, J.I. (1970). An eastward extension to the known range of the Olive Colobus monkey (Colobus verus van Beneden). Journal of the West African Science Association 15: 83-84.

22. Mertz, A. (1981). In litt.

23. Monfort, A. and Monfort, N. (1973). Quelques observations sur les grands mammifères du Parc National de Tai (Côte d'Ivoire). La Terre et la Vie 27(4): 499-506

24. Napier, J.R. and Napier, P.H. (1967). A Handbook of Living Primates. Academic Press, London.

25. Oates, J.F. (1979-84). In litt.

26. Oates, J.F. (1980). Report of a pilot study of Colobus verus and other forest monkeys in southern Sierra Leone with comments on conservation problems. Unpublished report.

27. Oates, J.F. (1982). In search of rare forest primates in Nigeria. Oryx 16(5): 431-436.

28. Röben, P. (1980). In litt.

29. Robinson, P.T. and Peal, A. (1981). Liberia's wildlife - the time for decision. ZooNooz 54(10): 7-21.

30. Roure, G. (1963). Conservation in the Côte d'Ivoire. IUCN Publications New Series 1:309-310.

31. Struhsaker, T.T. (1975). The Red Colobus Monkey. Chicago University Press, Chicago.

32. Tappen, N.C. (1960). Problems of distribution and adaptation of the African monkeys. Current Anthropology 1: 91-120.

33. Tappen, N.C. (1964). Primate studies in Sierra Leone. Current Anthropology 5(4): 339-340.

34. Teleki, G. (1980). Hunting and trapping wildlife in Sierra Leone: Aspects of Exploitation and Exportation. Unpublished report.

35. Teleki, G. and Baldwin, L. (1981). Sierra Leone's wildlife legacy: Options for survival. ZooNooz 54(10): 21-27.

36. Verschuren, J. (1983). Conservation of tropical rain forest in Liberia. Recommendations for wildlife conservation and national parks. Report of IUCN to the Government of Liberia.

37. Wilkinson, A.F. (1974). Areas to preserve in Sierra Leone. Oryx 12(5): 596-597.

38. Wolfheim, J.H. (1983). Primates of the World: Distribution, Abundance, and Conservation. University of Washington Press, Seattle and London. 
The IUCN Red Data Book

ENDANGERED

Colobus satanas Waterhouse, 1838

Order PRIMATES

Family CERCOPITHECIDAE

SUMMARY The Black Colobus is restricted to high canopy evergreen rain forest from Cameroon to the Zaire River. Numbers are declining as a result of hunting and habitat loss. It is apparently unable to survive in secondary forest after disturbance and a reduction in canopy height with logging. The species is now found only in protected or undisturbed inaccessible areas, including at least one reserve in Cameroon and it may be relatively abundant in intact forest areas of western Gabon. There are no reports of it being maintained in captivity. It is listed in Class B of the African Convention and in Appendix 2 of CITES.

DISTRIBUTION Colobus satanas has the most limited distribution of any of the five "Black Colobus" species $(20,21)$ and is restricted to south-west Cameroon, Equatorial Guinea including Bioko (Fernando Po), western and central Gabon $(4,18,30)$, and probably extending into Congo (Brazzaville) $(6,13,20,27)$. It does not occur in Zaire (19). It was previously seen throughout the $1000 \mathrm{~km}$ long and $240 \mathrm{~km}$ wide evergreen forest belt between the Sanaga and Zaire Rivers $(6,17,27)$. Early records of the inland extent of its range suggested eastern Gabon and western Congo (13), but the eastern end of the Dja Reserve in Cameroon is outside its range $(6,9)$. In Gabon, it is limited to central and western areas, with unconfirmed reports of sparse populations east of the Ogooué and Ivindo Rivers (9). It is now rare or absent in those parts of its former range where there has been extensive logging; its range in Rio Muni had been reduced to one third of its former size by 1967 (22), and is undoubtedly even less by this time (6).

POPULATION No estimates exist.

Cameroon Information on the species' status is patchy: it was considered rare even in the 1930s (13), and has undoubtedly declined since then (6); it has all but vanished from the Campo Reserve (6); it was reported to be abundant in the Douala-Edea Reserve in 1972 (26), and in 1978, densities were estimated at 38 animals, or a biomass of $176 \mathrm{~kg}$, per sq.km (14). However, McKey (14) also noted that densities were considerably lower elsewhere in the reserve where hunting had been more intense.

Equatorial Guinea Numbers are thought to have declined in Rio Muni $(6,22)$, although the species was considered abundant in 1972 in the mountains of the Abumnzok-Aninzok area (24).

Gabon Colobus satanas is common near Boué, but absent from areas near Makokou and further east and is probably declining throughout its range $(3,18)$. In the Lopé Reserve, numbers were estimated at 26 animals per sq.km (similar to those from Douala-Edea) but are variable from area to area (10). Densities in the Forêt des Abeilles, central Gabon, are also thought to be between 25-30 animals per sq.km (9).

Congo (Brazzaville) Its status is unknown.

HABITAT AND ECOLOGY The species lives in coastal evergreen rain forest, typically high in the canopy of dense, primary forest (6), and it has been found in montane (13) and swamp forests (30). It is reported to be unable to survive in secondary forest (30). The animals are diurnal and arboreal, feeding selectively; young leaves and seeds compose the bulk of the diet, while mature leaves tend to be avoided $(8,14,16)$. Over $50 \%$ of the day is spent inactive and about $22 \%$ spent feeding $(14,15)$. Home range sizes vary from 70 ha in coastal forests $(14,15)$ to 180 ha in inland forests (8). Day ranges are about $640 \mathrm{~m}$ and are longer when seasonally preferred foods are scarce $(14,15)$. Group sizes tend to be small, averaging from $6(25)$ to $13(22)$ in Rio Muni, 10 in Gabon $(8,10)$, and 15 in Cameroon $(14,15)$ and groups contain one or more adult males.

THREATS The main threats are habitat destruction (from logging and forest clearance for agriculture) and hunting. The species appears to be especially vulnerable to all forms of forest 


\section{Threatened Primates of Africa}

felling since high canopy habitats are essential and it is unable to survive in secondary forests $(6,20)$.

Cameroon Extensive logging of hardwoods between 1969 and 1971 has reduced the area of habitat $(28,30)$. The monkeys are preferred food and are intensively hunted $(20)$, even inside the Douala-Edea Reserve (14). The species is rare wherever people are present (20).

Equatorial Guinea While virtually all of the commercially valuable timber species had been removed by 1972 (26), C. satanas was reported to be present in dense forests of Matama and Okorobiko in 1973 (23). Sabater Pi estimated that 1000-1500 animals were killed annually for meat $(24,30)$. On Bioko, the survival of all primates has been of conservation concern since Independence. The species was intensively hunted in the south of the island, and no primates were observed in forests near Moka in 1964 (20).

Gabon While significant areas of intact forest remain, hunting of primates is extensive near areas of human settlements $(5,11)$, which if uncontrolled could threaten the fauna $(5)$.

Congo (Brazzaville) No information was obtained on the status of the species.

CONSERVATION MEASURES The Black Colobus needs effective protection against hunting, and forest loss. Further data on the status and distribution of $C$. satanas are urgently required, especially in Congo (Brazzaville), with a view to suggesting areas that might be suitable for reserves.

No hunting restrictions apply to the species in any nation (11). In Cameroon, permits are required to trap or export $C$. satanas (11), and in Gabon, primates may be exported under permit (11). It is effectively unprotected in Rio Muni (11). It occurs in Douala-Edea National Park in Cameroon, which has been protected from illegal logging since $1976(2,7,11)$ but the area is threatened by proposed oil exploration (1). Effective protection of the park is needed. It is also known to occur in the Lopé-Okanda Reserve in central Gabon $(8,10)$ and primates in this reserve are currently well protected from most logging and hunting pressures (9).

The species is included in Class B of the African Convention (1969); it may be hunted, killed, captured or collected only under authorization issued by the competent authority.

It is listed in Appendix 2 of the 1973 Convention on International Trade in Endangered Species of Wild Fauna and Flora, trade in it between acceding nations being therefore subject to regulation and monitoring of its effects.

CAPTIVE BREEDING Not known to be kept in captivity.

REMARKS For a description and photographs see $(12,13)$. The species has variously been considered to be a subspecies of other forms of Black-and-White Colobus, and is now separated on the basis of cranial, dental and vocal characteristics (21). For a review of the taxonomy of the Black-and-White Colobus see (21).

\section{REFERENCES}

1. Agland, P.C. (1983). Pers. comm.

2. Anon. (1976). Cameroun rainforest. Oryx 13(4): 340.

3. Brossett, A. (1980). In litt.

4. Dandelot, P. (1974). Part 3: Order Primates. In: Meester, J. and Setzer, H.W. (Eds), (1971-77). The Mammals of Africa: An Identification Manual. Smithsonian Institution Press, Washington, D.C.

5. Gandini, G. (1979). In litt.

6. Gartlan, J.S. (1977). In litt.

7. Gartlan, J.S. and Agland, P.C. (1980). A proposal for a program of rain-forest conservation and national park development in Cameroon, West-Central Africa. Unpublished report to the Gulf Oil Corporation. 
8. Harrison, M.J.S. (1986). Feeding ecology of Black Colobus, Colobus satanus, in central Gabon. In: Else, J.G. and Lee, P.C. (Eds), Primate Ecology and Conservation. Cambridge University Press, Cambridge.

9. Harrison, M.J.S. (1988). In litt.

10. Harrison, M.J.S. and Hladik, C.M (1986). Un primate granivore: Le Colobe Noir dans la foret du Gabon; potentialite d'evolution du comportement alimentaire. Rev. Ecol. (Terre Vie). 41: 281-298.

11. Kavanagh, M. and Bennett, E.L. (1984). A synopsis of legislation and the primate trade in habitat and user countries. In: Mack, D. and Mittermeier, R.A. (Eds), International Trade in Primates. TRAFFIC (U.S.A.).

12. Lydekker, R. (1905). Colour evolution in Guereza monkeys. Proceedings of the Zoological Society of London 2: 325-329.

13. Malbrant, R. and Maclatchy, A. (1949). Faune de l'Equateur Africain Français. 2. Mammifères. Encyclo pédie Biologique 36. Paul Lechevalier, Paris.

14. McKey, D.B. (1978). Plant chemical defenses and the feeding and ranging behaviour of Colobus monkeys in African rain forests. Ph.D thesis, University of Michigan.

15. McKey, D.B. and Waterman, P.G. (1982). Ranging behaviour of a group of Black Colobus (Colobus satanas) in the Douala-Edea Reserve, Cameroon. Folia Primatologica 39: 264-304.

16. McKey, D.B., Gartlan, J.S., Waterman, P.G. and Choo, G.M. (1981). Food selection by Black Colobus monkeys (Colobus satanas) in relation to plant chemistry. Biological Journal of the Linnaean Society 16: 115-146.

17. Napier, J.R. and Napier, P.H. (1967). A Handbook of Living Primates. Academic Press, London.

18. Nicoll, M. and Langrand, O. (1986). Conservation et utilization rationnelle des ecosystemes forestiers du Gabon. Report to WWF/IUCN.

19. Oates, J. (1984). In litt.

20. Oates, J.F. (1977). The Guereza and Man: How man has affected the distribution and abundance of Colobus guereza and other Black Colobus Monkeys. In: Rainier, H.R.H. III and Bourne, G.H. (Eds), Primate Conservation. Academic Press, New York and London.

21. Oates, J.F. and Trocco, T.T. (1983). Taxonomy and phylogeny of Black-and-white Colobus Monkeys. Folia Primatologica 40: 83-113.

22. Sabater Pi, J. (1970). Aportacion a la ecologia de los Colobus polykomos satanas Waterhouse 1838, de Rio Muni (Republica de Guinea Ecuatorial). P. Inst. Biol. Apl. (Barcelona) 48: 17-32.

23. Sabater Pi, J. (1973). Contribution to the ecology of Colobus polykomos satanas (Waterhouse, 1838) of Rio Muni, Republic of Equatorial Guinea. Folia Primatogica 19: 193-207.

24. Sabater Pi, J. and Groves, C. (1972). The importance of higher primates in the diet of the Fang of Rio Muni. Man 7: 239-243.

25. Struhsaker, T.T. (1969). Correlates of ecology and social organization among African cercopithecines. Folia Primatologica 11: 80-118.

26. Struhsaker, T.T. (1972). Rain-forest conservation in Africa. Primates 13: 103-109.

27. Tappen, N.C. (1960). Problems of distribution and adaptation of the African monkeys. Current Anthropology 1: 91-120.

28. United Nations (1974). Yearbook of International Trade Statistics 1972-1973. United Nations.

29. Verschuren, J. (1975). Wildlife in Zaire. Oryx 13(1): 25-33.

30. Wolfheim, J.H. (1983). Primates of the World: Distribution, Abundance, and Conservation. University of Washington Press, Seattle and London. 


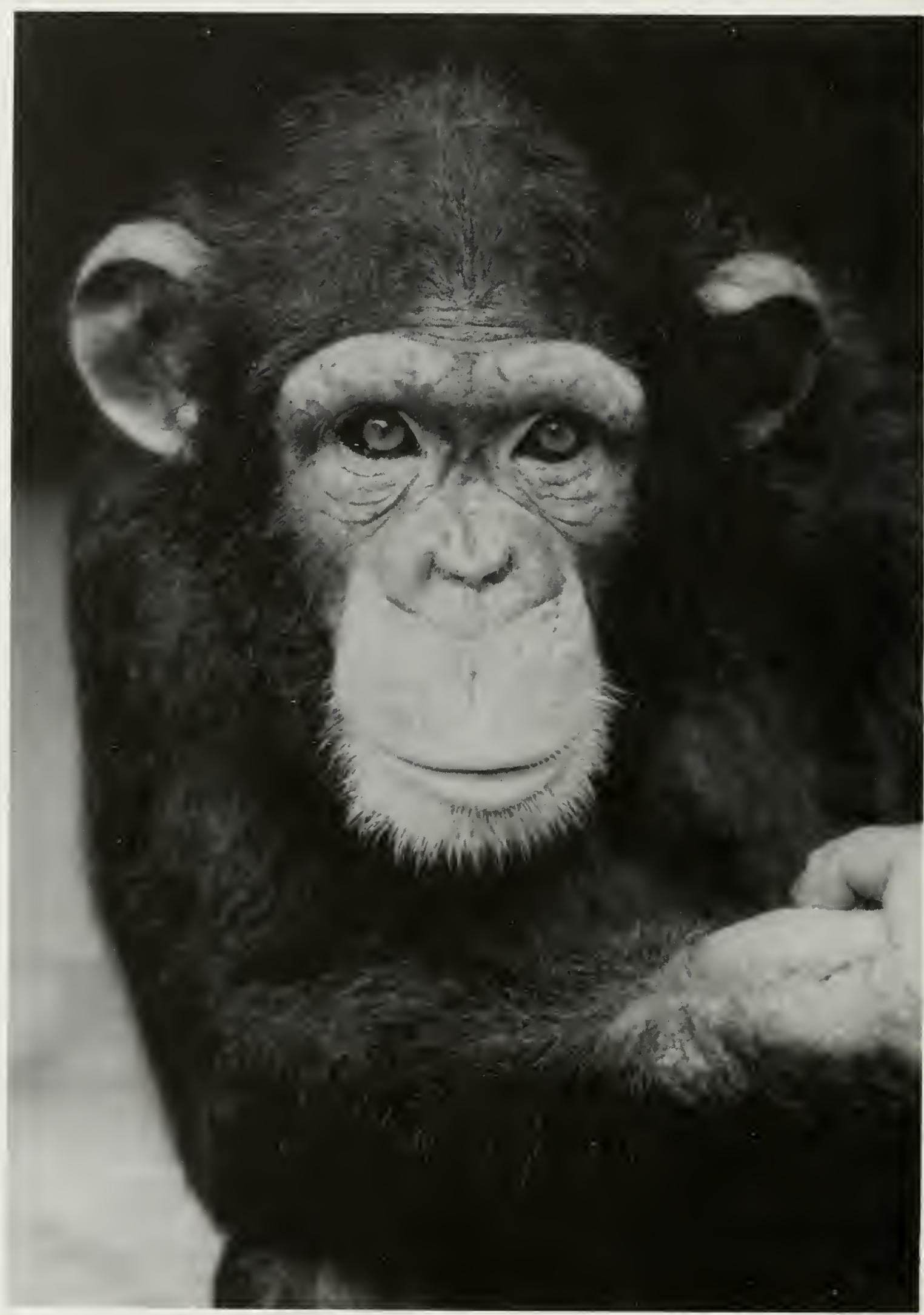

The Chimpanzee Pan troglodytes is threatened throughout much of its range in Equatorial Africa by hunting, habitat loss and the export trade.

Photo by Russell A. Mittermeier, WWF-US. 
The IUCN Red Data Book

SUMMARY The Chimpanzee has a wide but discontinuous distribution in Equatorial Africa between $13^{\circ} \mathrm{N}$ and $7^{\circ} \mathrm{S}(10,56,70,111,127)$. Three subspecies are usually recognized $(42,70,119,130)$. For a distribution map see (42). Current distributions within the various countries of the species' range are poorly known, and few accurate estimates of population size exist. For the continent as a whole, numbers of Chimpanzees in known localities are less than 20000 . Estimates based on area of suitable habitat which could potentially contain Chimpanzees suggest that a maximum of 200000 animals might remain in a variety of forest habitats $(108,111)$. Such estimates are highly speculative and much more information is needed on populations and their distributions in the different nations. The vast majority of the known and estimated numbers are thought to be found in only two of the 20 nations containing Chimpanzees. Around 65000 are found in Gabon (116) and a potential maximum of over 80000 could exist in Zaire (108). The remainder of the population is distributed in small numbers throughout the further 18 nations. The main threats to Chimpanzees come from hunting for meat, from habitat loss and from poaching for the biomedical export trade. This latter threat is particularly critical in light of the unpredictable demand for Chimpanzees in biomedical research and should be carefully monitored. Chimpanzees are listed in Class A of the African Convention (1969) and included on Appendix 1 of CITES. The three subspecies have different ranges and face different threats. They are summarized separately below.

The western subspecies, Pan troglodytes verus, occurs from southern Senegal eastwards as far as the Niger River in Central Nigeria $(42,70)$. The majority of the known population is currently confined to Guinea, with small populations in Sierra Leone, Liberia and Côte d'Ivoire. Only relict populations are found in Mali, Ghana and Senegal and the subspecies is extinct in the wild in six countries (Gambia, Guinea-Bissau, Burkina, Togo, Benin, and western Nigeria). Total numbers are estimated to be less than 17000 with 2000 in known habitats and 15000 in potential habitats (108). The main threat is the export trade for behavioural research and the biomedical industry. Allthough the trade has been extensively reduced in the past 15 years, it has not been eliminated. Over $95 \%$ of all overseas exports in recent decades has come from populations in West Africa $(28,56,107,112)$. Two wildlife dealers alone exported at least 1395 infants from Sierra Leone between January 1973 and April 1978, many of which were of illegal Guinean or Liberian origin $(56,83,107,112)$. This total probably represents between $5000-7000$ animals killed and removed from the wild, since mothers and older siblings are usually killed when infants are captured $(40,56,112,113)$. One current market for exports is Spain and the Canary Islands, where Chimpanzees are used by beach photographers for the tourist trade (54). Reproductive females are probably scarce in areas where commercial hunters have been operating in the recent past. Hunting for meat is a serious problem in some countries such as Liberia and Sierra Leone. Habitat loss as a result of logging activities and encroachment from cultivation are further threats. The species is protected by law in some countries, and healthy populations do exist in a small number of protected areas. However enforcement of legal protection, especially against poaching for export and meat does not appear to be effective in halting the decline in the populations of this subspecies. The establishment of additional protected areas with adequate levels of staffing and financial support is vital.

The central subspecies, $P$. $t$. troglodytes, ranges from Nigeria east of the Niger River to the Ubanghi River and south to the Zaire River (42). Flourishing populations are now found only where large areas of forest remain relatively undisturbed. The majority of the known population is found in Gabon, with substantial populations presumed to exist in Congo (Brazzaville), Cameroon and possibly in western Zaire. Small, isolated or relict populations are known from the Central African Republic, Rio Muni (Equatorial Guinea), eastern Nigeria and Angola. Estimates of population size in known localities are around 5000, but a further 80000 may exist in unsurveyed areas of suitable liabitat (108). The main threats to this subspecies are hunting for meat and habitat loss due to logging or the encroachment of cultivation. Hunting is a major 
problem in most countries since game meat is the primary source of dietary protein $(24,35,89,109)$, and large species such as Chimpanzees are both more desirable and more easily spotted (49). Capture for the export trade is not widespread, but could become a problem should the level of demand increase. Forest clearance has led to the reduction of forest cover in most countries and thus to declines in Chimpanzee numbers. Some legal protection exists in most countries, but the effectiveness of enforcement is poorly monitored and therefore unknown. Although some protected areas of habitat do exist throughout the subspecies' range, more efforts are required to establish conservation areas in remaining tracts of forest.

The eastern subspecies, P. t.schweinfurthi, is found north and east of the Zaire River, from the Ubanghi River in eastern Zaire to the Rift Valley lakes in the east, and from southern Sudan to the southern end of Lake Tanganyika near the Zambia border (42). Estimates of population size from known habitats are around 10000 , with a further $43000-86000$ animals possibly to be found in areas of potential habitat (108). The majority of the population is thought to be concentrated in the vast unsurveyed areas of eastern Zaire, but the status of Chimpanzees in this country is poorly known. Small populations are found in the western forests of Uganda and Tanzania, with tiny relict populations in Rwanda, Burundi and Sudan. Loss or fragmentation of forests due to the exploitation of resources in these areas is the main threat to this subspecies. The encroachment of agriculture into previously forested areas is a major problem in those nations which have rapidly expanding human populations and little land suitable for cultivation. Most nations have some protected forest areas and legal protection for Chimpanzees. The forest refuges are facing increasing pressure from human development needs and programmes of integrated forest managment are a priority for these nations.

Chimpanzees have been extensively studied in the wild and are highly social, livingin complex communities. They depend primarily on fruit in their diets and thus are restricted to areas of dense primary forest, or secondary forests where fruit trees remain. Some marginal populations live in dry, open woodlands, but need large ranges to sustain fruit intakes. Reproductive potential is influenced by the migration of females between neighbouring communities, and small isolated communities could suffer from inbreeding leading to reduced reproductive rates. Small communities are also vulnerable to local habitat disturbance, hunting pressure or epidemics, potentially leading to rapid local extinction. Chimpanzees have a long period of dependence on the mother and a late age of maturation, which combined with long periods between births of five to six years, leads to very low reproductive rates in the wilo. Their close genetic relationship with humans has led to extensive use of Chimpanzees as models of disease in biomedical research. Wild caught animals breed well in captivity, but captive reared animals have low fertility. Effective management of existing captive populations is essential for sustaining the demands for research.

STATUS BY NATION Detailed information on the distribution, population sizes, threats and conservation measures for each country containing Chimpanzees is listed below. Subspecies are presented separately.

Pan troglod ytes verus Schwarz, 1934

\section{Guinea}

DISTRIBUTION Chimpanzees are thought to be relatively abundant in the west and south-east corner $(83,111)$.

POPULATION No recent surveys have been made. Small populations are known from a variety of habitats, including gallery forest and forest patches surrounded by cultivation and secondary forests (101). Estimates, based on known local populations and area of suitable habitat, suggest a total population between $8000-10000$, with less than 2300 breeding females $(108,111)$. Guinea 
could thus contain up to $60 \%$ of the western subspecies (108).

THREATS Prior to the 1960 s, large numbers of Chimpanzees were exported for biomedical research (108). The extent of current threats from agricultural encroachment on forest habitats, from hunting or from export trade are unknown.

CONSERVATION MEASURES No legislation protecting Chimpanzees appears to exist (45). Chimpanzees are found in the Mount Nimba Strict Nature Reserve $(25,46)$, and in surrounding forest patches. One tiny population of 20 animals at Bossou (10 km from Mt Nimba) has remained stable in size since the 1960s (25). Chimpanzees are also said to occur in the Reserve de la Biosphere du Massif du Zaiama (46). Their behaviour has been observed at a number of locations since the $1920 \mathrm{~s}(3,17,55,56,58,75,101,102)$. However, population sizes, distribution, and status of protected areas remain unknown. Further information is essential before conservation measures can be recommended.

\section{Sierra Leone}

DISTRIBUTION Chimpanzees are widely distributed at low densities throughout most parts of the country $(25,77)$. The largest concentrations are thought to occur in the north near the border with Guinea $(77,111)$. They are known from the Gola Forest complex in the south-east $(25,38,77)$.

POPULATION A nationwide wildlife survey in 1980 concluded that the species had declined drastically in the past 20 years, and that the population was only about 2000 animals with fewer than 500 breeding females (114). However, this total may be an underestimate and the degree of the decline is uncertain (77).

THREATS Habitat loss, subsistence hunting for meat and trapping for a local pet trade or for export are the major threats $(111,114)$. Human population increases and consequent needs to expand areas of agricultural land during the past 100 years reduced the previously extensive forest cover to less than $4 \%$ of the land surface by 1964 (106). Few areas of suitable habitat thus remain undisturbed, and clearance and timber extraction are still serious sources of habitat loss (25). Sierra Leone has been one of the primary sources of Chimpanzees for export for the biomedical industry. Between 1959-1979 over 2000 infants were exported to Europe, North America and Japan (114). In 1978, a Presidential Ban was imposed on exports which reduced, but did not eliminate, the trade. A minimum of 30 animals were exported to Japan in 1983 alone (62). Exports to Europe also continue (108). Systematic hunting by commercial gangs of poachers is probably the most serious threat at present (25).

CONSERVATION MEASURES Young Chimpanzees are Protected Animals under the 1972 Wild Life Conservation Act. Trade in captive animals is regulated by permit (45). Although the 1978 Presidential Ban on exports of infants still exists, this does not have the status of formal law. While ratification of CITES by Japan has led to a reduction in that country's imports (62), controlling the trade at itssource is one of the major measures necessary for protecting the animals remaining in the country. Chimpanzees occur in the Gola Forest Reserves (25), and in the proposed Outamba-Kilimi National Park in the north of the country $(25,46,114)$. This area contains a small population of $60-75$ animals in 240 sq. $\mathrm{km}$. (38). A major research and conservation programme is in progress in the Gola Forest Reserves $(25,77)$. The nationwide survey of wildlife in 1980 had as one primary aim the determination of numbers and distributions of Chimpanzees $(109,112)$. In order to increase the level of protection afforded to the species, measures to gazette areas of forest reserves and national parks need to be implemented urgently (25).

\section{Liberia}

DISTRIBUTION Chimpanzees are rare, but found throughout the country in areas of protected forest (79).

POPULATION No nationwide surveys have been made. Estimates based on areas of suitable habitat suggest that the population could total between 2000-4000 (108) with at least 600 breeding females (108). In 1983, Peal considered the population to be stable, and potentially abundant in undisturbed forest areas (80).

THREATS Habitat destruction and capturing for export for biomedical research are the most serious threats (80). Chimpanzees are also captured for the pet trade, and hunted for meat (47). Between 1958 and 1958, at least 570 Chimpanzees were exported from the country (85). 
CONSERVATION MEASURES The species is protected by law and national and international trade is regulated or restricted (45). The effectiveness of this legislation against poachers working for the export trade is unknown. Chimpanzees are found within the Sapo National Park, which was only recently $(1984)$ gazetted $(5,6,7,46,86)$. The density of Chimpanzees in the park was found to be low during a 1982 survey (5). No estimates of the population contained within the park yet exist. The species may be found in the Loffa-Mano Reserve (46), but their presence has not been confirmed. Accurate information on population numbers and distributions are needed for the country before appropriate conservation measures can be suggested. A rehabilitation project attempting to reintroduce wild-born animals from laboratories in Liberia or which were kept as pets is underway on a small island in a river near Robertsfield (33).

\section{Côte d'Ivoire}

DISTRIBUTION Prior to the 1960s, Chimpanzees were thought to be widespread in the country $(55,56)$. Currently only small populations are known from protected forest areas primarily in the south-west along the border with Liberia (111). No further specific information is available.

POPULATION Estimates from known populations and areas of suitable habitat place the total numbers at less than 750 , with fewer than 175 breeding females $(108,111)$.

THREATS Hunting and logging, especially within protected areas, have been suggested (108).

CONSERVATION MEASURES The species is fully protected by law and trade is regulated by special permit (45). The effectiveness of these regulations has not been assessed. Chimpanzees are known to occur in the Tai National Park, where their behaviour and ecology has been studied $(14,15,65)$. They are also listed as present in Comoe National Park, Marahoue National Park, Mount Nimba Strict Nature Reserve, and Mont Peko National Park (46). Their presence in these areas and the status of the parks need confirmation. Chimpanzees previously were found in Banco National Park, but have been exterminated (111). A rehabilitation project, started with animals from a biomedical research facility, is in progress on Bandama Island near Azagny National Park $(13,82)$, but has had only limited success.

\section{Mali}

DISTRIBUTION Chimpanzees are known to occur only in the south-east near the borders with Guinea and Senegal $(66,91)$. The northern limit of the species appears to be south of a line projecting due east from the Senegal border to Manantali, from there to Kita and on to Bamako (66). Chimpanzees appear to use areas of riparian forest and nests were found in open woodland well away from rivers, as well as around cliffs with small waterholes (67).

POPULATION Chimpanzees are widespread in this southern area, but are found at low densities (66). A brief survey in December 1984 confirmed the presence of Chimpanzees through observations, counts of nests and interviews with residents (66). Total population was estimated to be between $500-1000$ based on densities comparable to other dry woodland habitats (66). Previous estimates of the population were low; 100 animals with 25 breeding females (111). The recent survey suggests a healthy population with greater potential for protection.

THREATS Hunting for meat, or more commonly medicinal purposes, is a minor threat and they are occasionally kept as pets in villages (66). Although Chimpanzees do not currently appear to be threatened, Moore considered them highly vulnerable should any illegal export trade start operating. People knew of their locations and could hunt them with ease, potentially leading to their extermination within the space of one year (66).

CONSERVATION MEASURES Chimpanzees are protected by law and national and international trade is regulated or restricted. Chimpanzees previously occurred in the Baoule National Park, but they no longer are seen in the area (66). A national park along the west bank of the Bafing River has been proposed, which would potentially protect between 50-150 animals and their habitat (66). No further protected areas of Chimpanzee habitat exist in the country. More information is needed on the status of the species before additional conservation measures can be suggested. 


\section{Ghana}

DISTRIBUTION Only a few relict populations survive in the south-west $(8,48,111)$.

POPULATION One or possibly two separate populations survive in national parks and total numbers are estimated to be less than 400 , with fewer than 90 breeding females (108).

THREATS Hunting of Chimpanzees for meat and, to a lesser degree, logging may pose threats to these small populations (108). The tiny population size would be vulnerable to any major habitat disturbance or to diseases.

CONSERVATION MEASURES Chimpanzees are protected by law and national and international trade is regulated or restricted (45). They are found in Bia National Park and in the Nini-Souhien National Park and adjacent Ankasa Game Production Reserve $(8,46,61,111)$. A rehabilitation project was attempted in Bia National Park but was abandoned through lack of funds $(108,111)$.

\section{Senegal}

DISTRIBUTION Chimpanzees are thought to occur only in the south-east of the country. Confirmed reports come only from the area of Mt Assirik $\left(12^{\circ} 53^{\prime} \mathrm{N}, 12^{\circ} 46^{\prime} \mathrm{S}\right)$ in Niokolo-Koba National Park $(11,27,64,118,125)$ but they may occur in areas to the east and south of the park (63).

POPULATION The known community at Mt Assirik numbers between 25-37 animals (118), and the populations outside the park probably are less than 100 in total (63). Chimpanzee densities in dry woodland tend to be low $(64,118)$, and numbers elsewhere are unlikely to be high, or to total more than 300 in the country (108).

THREATS Although Chimpanzees are protected within the national park, plans proposed to dam the Gambia River on the southern boundary of the park could threaten this population. Innundation of the essential gallery forest habitats, habitat disturbance from supporting developments such as roads and settlements, and the isolation of populations separated by higher river levels all could contribute towards the rapid demise of Chimpanzees in this area (63). CONSERVATION MEASURES The species is protected by law and national and international trade is regulated or restricted (45). Protected in Niokolo-Koba National Park, where studies of behaviour and ecology have been made $(11,13,64,118)$. A reintroduction project was attempted near Mt Assirik, but hostility from resident wild Chimpanzees forced the project to move to the Gambia (60).

\section{Gambia}

In the wild, Chimpanzees became extinct at the turn of the century (83). Two projects exist which are attempting to rehabilitate and reintroduce Chimpanzees in the Gambia. There is an orphanage in the Abuko Nature Reserve for young Chimpanzees that have been confiscated from poachers or that have been zoo-reared $(60)$. Chimpanzees have also been reintroduced into the wild on Baboon Island in the River Gambia National Park (18). This attempt to reintroduce captive Chimpanzees has proved highly successful to date (16). Chimpanzees have full legal protection (45).

\section{Guinea Bissau}

In the early 1960s Chimpanzees were thought to occur along the south-east border with Guinea $(56,111)$, but their presence was confirmed only in Guinea. By 1978 , they were considered extinct in the country (83) although some areas of suitable habitat still remain which potentially could contain 100 animals (108). The species is listed as protected under wildife legislation (45).

\section{Burkina}

Extinct $(83,111)$. Unconfirmed sightings suggest that Chimpanzees from Côte d'Ivoire may cross into forested areas in the south-west during rainy periods. Although resident Chimpanzees are extinct, the species is protected by law and national and international trade is regulated or restricted (45). 


\section{Togo}

In the early 1960s a small population was reported from the south-west corner on the border of Ghana $(56,58)$. In 1971, they were listed as present in the Koue and Kamassi Reserves $(40,111)$. By 1978 , Chimpanzees were considered to be extinct in the country $(83,111)$. The species is protected by law and national and international trade is regulated or restricted (45).

\section{Benin}

Extinct $(57,58,92)$. Chimpanzees are thought to have been widespread in the south-eastern and central forests, but have been exterminated in recent decades (92). No legislation protecting Chimpanzees exists (45).

\section{CENTRAL CHIMPANZEE}

VULNERABLE

Pan troglod ytes troglodytes Blumenbach, 1779

\section{Gabon}

DISTRIBUTION Chimpanzees occur throughout the country in all types of forest. They are found at the highest densities in areas of primary rain forest covering $85 \%$ of the country, at lower densities in savannah habitats, and are absent only in areas of intense human activity $(116,117)$.

POPULATION A nationwide census carried out between 1980-1983 estimated the numbers of Chimpanzees to be $64000 \pm 13000(116,117)$. Since the human population of Gabon is low and projected to increase relatively slowly (12), and large areas of forest remain undisturbed, Chimpanzees can still be considered as safe $(116,117)$.

THREATS The most serious threat is local hunting for meat. Rural people have no tradition of raising livestock and rely heavily on hunted forest animals for their protein intake (116). Selective logging is a lesser threat. Although the habitat is changed, and lower densities of Chimpanzees are typically found in logged areas (94), these densities return to normal levels 3-6 years after logging $(116,117)$. However logging and supporting road building and development increase the requirements for meat, and hunting pressure is intensified in logged areas (12).

CONSERVATION MEASURES Chimpanzees have had total legal protection since 1967 in Gabon, although the law is rarely enforced in rural areas $(116,117)$. Young Chimpanzees are occasionally offered openly for sale and have been confiscated by the authorities (117). No national parks have yet been established in the country but both the proposed Ogooué-Onangué and the Nogouié National Parks have Chimpanzees, as well as many other primate species (12). The species occurs in the Sette-Cama Nature Reserve and the Wonga-Wongué Reserve (46). In the Lopé Reserve, heavy logging and plans for further logging might affect resident Chimpanzees. The M'Passa Biosphere Reserve near Makakou also contains Chimpanzees, but despite complete legal protection of all animals and plants there is heavy poaching of all species including Chimpanzees, and the area is further threatened by encroaching cultivation (12). The Moukalaba Game Reserve in the south-west also contains Chimpanzees (71). One of the aims of the census project funded by the Centre International de Recherche Medicale de Franceville (CIRMF) is to identify areas of high Chimpanzee density with no conflicting human interests in order to establish new protected areas $(116,117)$.

\section{Congo (Brazzaville)}

DISTRIBUTION No information is yet available on the distribution of Chimpanzees in the Congo. Although the country has extensive areas of forest, reports of Chimpanzees come primarily from the north and along the border with Gabon $(55,108)$.

POPULATION Surveys have just been completed (1987), but no data are yet available (73). Estimates based on area of suitable habitat suggest a total of between 3000-5000 (108). 
THREATS None specifically mentioned, but reports suggest that hunting and habitat disturbance due to logging may have led to a decline in numbers (108).

CONSERVATION MEASURES Protected by law, and wounding of animals is required to be reported. Export is possible only by permit (45). Chimpanzees probably are found within the recently created Conkouati Conservation Area $(46,96,124)$, which consists of a national park and reserve in the south-west adjacent to Gabon, and extends from the coast to the Kouboula Mountains (96). They are also believed to occur in Odzala National Park in the north-west (46). The distribution and population sizes of Chimpanzees in the country need to be confirmed before conservation priorities can be determined.

\section{Cameroon}

DISTRIBUTION Chimpanzees are probably most common in the relatively undisturbed forests of the south-east (39), and isolated populations exist along the western coast (108). They were previously found in forests along the border with Nigeria (108) and highland forests in the region of Mount Cameroon $(30,78)$. Their current status in these areas is unknown.

POPULATION No census has been made. Even in south-eastern forests they are nowhere common, and unlike Gabon (116) they appear to exist at lower densities than do Gorillas (39). Maximum numbers are estimated to be less than 10000 (108). Accurate population estimates are urgently needed.

THREATS Chimpanzees are hunted for meat $(39,111)$ but the effect of such hunting is unknown. Plans for logging forested areas could pose a threat, but currently logging is relatively limited (39).

CONSERVATION MEASURES Chimpanzees are protected by law, but there are no restrictions on trade (45). They are known to occur in the Dja Forest Reserve (46), Campo Reserve (111), and Korup National Park $(78,111)$. They are thought to be present in Takamanda Reserve (78,111), in Douala-Edea Forest Reserve (46), and the South Bakundu Forest Reserve $(30,111)$. The current status of these protected areas is unknown. In the south-eastern forests, logging is still limited in extent and the future development of the region is being planned. This area could potentially benefit from the establishment of protected areas which would safeguard areas of Chimpanzee habitat (1). More information is needed on population sizes and distribution throughout the country before conservation measures can be recomended.

\section{Central African Republic}

DISTRIBUTION Chimpanzees are known to occur in the south-west of the country, but at low densities (21). This habitat may be less preferred than the forests of the south-east (95), where most previous observations have been made $(56,58,83,111,119)$.

POPULATION No nationwide census has been carried out and only scant data are available on densities from one south-western forest (21). In the Dzanga-Sangha region, very low numbers of Chimpanzees $(0.01-0.13 \mathrm{sq} . \mathrm{km}$ ) have been counted (21). No other numbers are available, and estimates based on area of suitable habitat range from 800-1000 (108). Essentially the population is unknown.

THREATS Spinage (FAO wildlife advisor to C.A.R.) thought that the Chimpanzee was not facing any specific threats (95), but hunting could be a minor problem (108). There is no evidence of trade.

CONSERVATION MEASURES Chimpanzees are protected by law and international trade is regulated or restricted (45). Chimpanzees are reported to occur in the Basse-Lobaye Forest Reserve (proposed as a UNESCO Biosphere reserve in 1977) (46) and are known to occur in the, as yet, ungazetted forest reserve in Dzanga-Sangha region (21). Further information on the status of these proposed protected areas is needed, as well as additional data on population sizes and distributions throughout the country, before conservation measures can be recommended.

\section{Rio Muni (Equatorial Guinea)}

DISTRIBUTION Field studies of Chimpanzees in the 1960s found that their distribution coincided with those areas of mature primary forests existing in a few undisturbed parts of the country. Chimpanzees were also found in relict stands of tall trees surrounded by disturbed vegetation $(47,87,90)$. For maps, see $(50,90)$. 


\section{Threatened Primates of Africa}

POPULATION No recent census has been made. Total numbers in 1980 were estimated by Sabater Pi (88) to be close to 1500 with 150 breeding females. Teleki (108) suggested a total of 2000 animals, with 460 breeding females. The species was common in the forests of Abumnzok-Aninzok region $\left(1.28^{\circ} \mathrm{N}, 10.05^{\circ} \mathrm{E}\right)$, and in the Monte Alén region $\left(1.45^{\circ} \mathrm{N}, 10.15^{\circ} \mathrm{E}\right)$ (87).

THREATS Prior to the late 1960 s, vast areas of forest habitat were destroyed in Rio Muni $(50,90)$. However, periods of political and social unrest led to the abandonment of commercial logging schemes, a reduction in human population through emigration and concentration of the populace in coastal regions $(88,89)$, reducing the threats to Chimpanzees. The return to political stability may encourage forest exploitation, in combination with increasing human population sizes, which could place pressures on Chimpanzees $(50,88,89)$.

CONSERVATION MEASURES Hunting of Chimpanzees as game is regulated by law, as is national and international trade (45). The effectiveness of these regulations is unknown. The status of Chimpanzees in protected areas urgently needs to be assessed as well as their distribution and population sizes throughout the country. Conservation priorities need to be determined for integration into plans for economic development.

\section{Nigeria}

DISTRIBUTION A few relict populations survive in the south-east, near the border with Cameroon $(34,83,111)$. Recent reports confirm the presence of Chimpanzees in montane forests $(1500 \mathrm{~m})$ south of the Obudu Plateau (69) close to the border with Cameroon. The western subspecies, which was previously found in the south-west, is probably extinct (4).

POPULATION No current information is available on population sizes, but censuses are underway (69). Only very small isolated populations survive, which may lack long-term viability even if immediately protected (111).

THREATS Hunting of Chimpanzees for meat is known, but the degree of threat has not yet been determined (69). Heavy hunting pressure in Cameroon may have led to the concentration of Chimpanzees in the southern regions of Nigeria.

CONSERVATION MEASURES Laws protecting the species and regulating or restricting national and international trade have been enacted (45), but their effectiveness is unknown. The presence of Chimpanzees in the Bosni and Oban Forest Reserves and Gasaka/Gumti Game Reserve is now confirmed (69), but these areas are not fully protected, and their status needs to be assessed. Previously, Chimpanzees were reported from the Obudu Game Reserve $(46,81,111)$ and from Ifon Forest Reserve in Ondo State $(46,61)$, as well as recent sightings in the Afi River and Boshi-Okwango Forest Reserves in the Sonkwala Mountains (37). Information is urgently needed on the present distribution and population size of the species before effective conservation measures can be recommended.

\section{Angola}

DISTRIBUTION Chimpanzees are known to occur in the Cabinda enclave north of the Zaire River $(28,44)$, but no details of their distribution are available.

POPULATION No census has been undertaken. Based on area of suitable habitat alone, between 200-500 animals potentially could occur in the region (108).

THREATS Some habitat alteration has taken place Cabinda $(28,76)$, but how this might affect the Chimpanzee population is not known. Hunting of Chimpanzees for meat may pose a threat $(16,108)$.

CONSERVATION MEASURES Chimpanzees are protected by law and national and international trade is regulated or restricted (45). The effectiveness of these regulations is unknown. No protected areas occur in the enclave. Surveys are necessary to determine the status of the species and to recommend appropriate conservation measures. 
Pan troglod ytes schwein furthi (Giglioli, 1872)

\section{Zaire}

DISTRIBUTION Chimpanzees are known from a number of forested areas in the country. They appear to be rare but widely distributed in the Ituri Forest (41), and are present along the eastern regions parallel to the Rift Valley stretching from the Sudan border in the north to the south end of Lake Tanganyika $(108,111)$. They also occur in the north-west near the Congo border (108).

POPULATION No nationwide survey has been attempted and population estimates are vague. Verschuren noted in 1975 that the species was "relatively common" in forests on the right bank of the Zaire River (121), but a 1985 survey of the Ituri Forest found Chimpanzees to be uncommon, and groups were infrequently seen (41). The maximum population in known localities was estimated to be 2000 (108). Estimates of numbers in unsurveyed areas of potential habitat range from 65000 to 84000 (108). These large numbers remain highly speculative and a more realistic total might be in the range of 20000 (108).

THREATS Deforestation and commercial hunting for urban markets (41) as well as capture for pet or export trades (126) appear to be the main threats.

CONSERVATION MEASURES Chimpanzees are protected by law and national and international trade is regulated or restricted (45). They probably occur in Garamba National Park $(46,111)$ and in Kahuzi-Beiga National Park (46). The degree and effectiveness of protection within national parks is not known. In Virunga National Park, a programme of Chimpanzee protection has been initiated in order to aid conservation of mature forests and encourage and control tourism, in conjunction with the Zaire Gorilla Conservation Project (22). One centre for maintaining confiscated captive Chimpanzees has also been established (126). More information on current distribution and status is needed before effective conservation measures can be recommended. In particular, the presence and distribution of the central subspecies in central or western areas needs to be determined.

\section{Uganda}

DISTRIBUTION Chimpanzees are known from a number of forested areas in western Uganda only (100).

POPULATION No overall survey has been made, but estimates of population size from known habitats suggest 2000 animals, with an additional 2000-3000 animals potentially occurring in unsurveyed areas of appropriate habitat (108).

THREATS Some populations are known to have declined drastically as a result of habitat loss in the last decades $(2,98,99,105,111)$. Chimpanzees appear to be particularly vulnerable to disturbance and forest fragmentation from logging activites and densities are much lower than in surrounding unlogged area $(31,49,94)$.

CONSERVATION MEASURES Chimpanzees are protected by law and national and international trade is regulated or restricted (45). They are thought to occur in the Gorilla Game Sanctuary (46), but this tiny $30 \mathrm{sq}$. $\mathrm{km}$ reserve is highly disturbed by settlements within its boundaries and surrounding human activities (9). They are well protected in the Kibale Forest Corridor Game Reserve and the Toro and Budongo Forests $(20,31,98)$. They also occur in the Rabongo Forest of Murchison Falls (Kabalega) National Park (46) and small populations may be found in Kigezi Game Reserve $(46,98)$. Minimizing habitat disturbance or loss due to forestry both within and outside protected areas is a major priority for ensuring effective conservation of Chimpanzees in the country.

\section{Tanzania}

DISTRIBUTION Chimpanzees occur only in western Tanzania where patchy, dispersed populations live in forested areas along the shores of Lake Tanganyika $(51,53,68,83,111)$. They range through western Kigoma and northern Mpanda Districts from the Burundi border (68) as far south as the Wansisi Mountains $\left(6^{\circ} 38^{\prime} \mathrm{S}\right)$ and inland from the lake as far east as the Ugalla 
River $\left(31^{\circ} 01^{\prime} \mathrm{E}\right)(52)$. The total area covers approximately $9500 \mathrm{sq} . \mathrm{km}(52)$.

POPULATION In the early 1970 s Kano estimated the population to be over 2000 , with most animals found in the area of the Mahale Mountains and adjacent woodlands inland from the lakeshore (51,52). A small population of 160 is known from Gombe National Park (32). Estimates for the country suggest a maximum of 2500 animals (108).

THREATS Habitat loss from increasing expansion of cultivation into areas inhabited by Chimpanzees is the major threat (32).

CONSERVATION MEASURES Chimpanzees are protected by law and export is banned (45). They are well protected in Gombe National Park and Mahale Mountains National Park, where they have been extensively studied for the past 25 years $(32,52,53,59,72)$. Chimpanzees have been introduced onto Rubondo Island National Park where they are breeding successfully (108).

\section{Burundi}

DISTRIBUTION Isolated units are found in forested areas north of Lake Tanganyika $(73,122,123)$.

POPULATION Recent surveys (1987) found two extant populations. In Kibira National Park, the population was estimated to be between 200-250 animals. A second smaller population of less than 50 animals was found in Rumango-Bururi Forest Reserve (73).

THREATS The expansion of cultivation into previously suitable habitats and resulting deforestation is probably the main threat $(108,122)$.

CONSERVATION MEASURES Chimpanzees are not protected by any existing wildlife regulations, but export of primates is illegal (54). The status of the national park and forest reserves needs urgent assessment, particularly with respect to their increasing isolation and thus the vulnerability of the Chimpanzees to extinction.

\section{Rwanda}

DISTRIBUTION Restricted to the Nyungwe Forest Reserve in the south of the country (36). Previously Chimpanzees were known from the Gishwati Forest (near Ruhengeri), and at least 13 still remain (97). They were thought to occur in some other forested areas in the past $(83,111)$.

POPULATION Preliminary surveys in 1982 confirmed the existence of Chimpanzees in the Nyungwe Reserve, but no counts were made (36). Estimates of uncertain accuracy suggest that 100-200 animals may remain (108), but these numbers await confirmation.

THREATS The Nyungwe Reserve has been heavily disturbed through mineral exploitation and supporting road building. Selective logging and reforestation with exotic species is also a threat (36).

CONSERVATION MEASURES Chimpanzees are protected by law and national and international trade is restricted (45). Hunting is not common (36). The Nyungwe Forest Reserve is $4 \%$ of the land surface in Rwanda and with effective management could act as a refuge for Chimpanzees and many other species of primates (36). It is currently the focus of studies on the effects of disturbance on primate communities (120). To ensure the continuance of Chimpanzees in the reserve, habitat disturbance needs to be minimized and effective integrated management of forest and mineral resources should be instituted.

\section{Sudan}

DISTRIBUTION Relict populations are thought to survive in the south-west of the country, west of the Nile $(19,26)$, and in forest areas on the border with Zaire such as the Aloma Plateau near Yei (26).

POPULATION No information is available. Estimates of population based on area of suitable habitat alone range from 100 (111) to 400 (108), with fewer than 70 breeding females (108). The species could be considered highly endangered if not already extinct in the country.

THREATS Capture of animals for the pet trade and habitat loss have been suggested as threat (26).

CONSERVATION MEASURES Chimpanzees are a totally protected species under the 1975

Wildlife Conservation and Parks Act (26) and national or international trade is restricted (45). They are thought to occur in the Mbarizunga, Bangangai and Bire Kpatuos Reserves (26). More information is needed on their status and that of the reserve areas before conservation measures can be recommended. 
HABITAT AND ECOLOGY Chimpanzees live in a wide variety of habitats, from humid evergreen forests, though mosaic woodlands and deciduous forest to dry savanna woodlands $(42,52,53,55,56,64,103)$. They are found from sea level in West Africa to $3000 \mathrm{~m}$ in some parts of East Africa $(17,74)$. The presence of surface water throughout the year is an important factor in limiting their distribution $(11,53,55,60,66)$. Animals living in dry areas tend to have larger ranges and lower densitites (0.07-0.38 per sq. $\mathrm{km}$ ) than do those in denser canopy forests or mosaic woodlands (3.0-5.0 per sq. $\mathrm{km})(11,43,64,104,115,129)$. Such high densities are found only at a small number of sites (Gombe and Mahale Mountains in Tanzania, Budongo Forest in Uganda, Beni Reserve in Zaire, and possibly at Mt Cameroon (111)). An optimal habitat cannot yet be defined, and densities appear to vary without an obvious relationship to habitat types $(103,111,129)$.

Chimpanzees eat a wide range of foods, with a concentration on fruits, flowers and seeds, but including some young leaves and a variety of small mammals and invertebrates $(31,32,128,129)$. As many as 330 food types can be eaten in a year (110). Diets can be diverse in terms of the numbers of foods and variable from area to area as a function of food availability, but they are characterized by the dominance of ripe fruits from forest trees (128). Movement between foraging sites often takes place on the ground but at least $1 \%$ of tree cover is necessary for the provision of food sites and nesting or sleeping sites (128).

Chimpanzees live in communities (or "unit groups") of between 20-106 animals $(32,43)$, with an average size of about 35 animals (128). Foraging and travelling parties are between 2-10 animals and are fluid in composition $(31,72,128)$. Adults often travel alone, especially when food is scarce (129), which makes them vulnerable to hunting or trapping. Individuals, usually females, move between neighbouring communities $(32,43,128)$ while males remain and appear to defend the boundaries of their ranges $(32,74)$.

In the wild, Chimpanzees have very low reproductive rates. They reach sexual maturity late, at around $10-13$ years, and typically give birth every six years $(32,43)$. Infants are highly dependent on their mothers for the first five years $(23,32,115)$. With a reproductive lifespan of around 25 years, four to five infants could be produced by a single female (115). In the wild, however, it is unlikely that more than three will be raised (32).

CAPTIVE BREEDING Around 1770 animals exist in captivity (93), with over 1400 in the U.S. alone (29) for research and display purposes. Although they appear to breed successfully in captivity, a 1985 survey of U.S. animals found that only eight males and 27 females born in captivity and of reproductive age had ever reproduced (29). Only about $16 \%$ of captive reared males breed, compared to over $80 \%$ for wild caught males (93). Few animals are kept in conditions to promote reproduction and there is high mortality $(21 \%)$ of infants in their first year (93). With the reproductive senescence of wild caught animals expected within five years, there is an urgent need to manage captive populations to increase reproductive rates and sustain the requirements for captive animals $(29,93)$.

REMARKS For a description of the species see $(42,70)$.

The following people very kindly contributed information on the status of the Chimpanzee: Jim Moore, Jane Goodall, Geza Teleki, Caroline Tutin, Michel Fernandez, Bill McGrew, Amy Vedder, Conrad Aveling and Adrian Kortlandt.

\section{REFERENCES}

1. Agland, P. and Harrison, M.J.A. (1987). Proposal for three rain forest national parks in Southeast Cameroon. Manuscript for Ministry of Tourism.

2. Albrecht, H. (1976). Chimpanzees in Uganda. Oryx 13(4): 357-361.

3. Albrecht, H. and Dunnett, S.C. (1971). Chimpanzees in Western Africa. R. Piper and Co., München.

4. Anadu, P.A. and Oates, J.F. (1982). The status of wildlife in Bendel State, Nigeria, with recommendations for its conservation. Report of IUCN/WWF Project 1613.

5. Anderson, J.R., Williamson, E.A. and Carter, J. (1983). Chimpanzees of Sapo Forest, Liberia: Density, nests, tools and meat-eating. Primates 24(4): 594-601. 
6. Anon. (1984). Sapo National Park in West Africa: Liberia's first National Park. American Journal of Primatology 6: 74-75.

7. Anon. (no date). Sapo National Park. Leaflet of the Division of Wildlife and National Parks, Monrovia, Liberia.

8. Asibey, E.O.A. (1978). Primate conservation in Ghana. In: Chivers, D.J. and Lane-Petter, W. (Eds), Recent Advances in Primatology, Vol. 2, Conservation. Academic Press, London.

9. Aveling, C. and Harcourt, A.H. (1984). A census of the Virunga Gorillas. Oryx 18: 8-13.

10. Baldwin, L.A. and Teleki, G. (1973). Field research on Chimpanzees and Gorillas: An historical, geographical, and bibliographical listing. Primates 14:315-330.

11. Baldwin, P.J., McGrew, W.C. and Tutin, C.E.G. (1982). Wide-ranging Chimpanzees at Mt. Assirik, Senegal. International Journal of Primatology 3(4): 367-385.

12. Barnes, R.F.W. and Jensen, K.L. (1987). Forest elephant survey progress report 1986-87. Report for Wildlife Conservation International (NYZS), New York.

13. Bemojo, M., Illera, G. and Sabater Pi, J. (in press). New observations on the tool-behaviour of the Chimpanzees of Mt. Assirik (Senegal, West Africa). Primates.

14. Boesch, C. and Boesch, H. (1981). Sex differences in the use of natural hammers by wild Chimpanzees: A preliminary report. Journal of Human Evolution 10: 585-593.

15. Boesch, C. (1978). Nouvelles observations sur les Chimpanzes de la forest de Tai (Cote d'Ivoire). La Terre et la Vie 32: 195-201.

16. Bothma, J. du P. (1975). Conservation status of large mammals of Southern Africa. Biological Conservation 7: 87-95.

17. Bournonville, D. de. (1967). Contribution a l'étude du Chimpanzé en République de Guinée. Bulletin de l'Institut Fondamental d'Afrique Noire 29: 1188-1269.

18. Brewer, E. (1984). Pers. comm.

19. Butler, H. (1966). Some notes on the distribution of primates in the Sudan. Folia Primatologica 4: 416-423.

20. Butynski, T.M. (1985). Primates and their conservation in the Impenetrable (Bwindi) Forest, Uganda. Primate Conservation 6: 68-72.

21. Carroll, R.W. (1986). Status of the Lowland Gorilla and other wildlife in the Dzanga-Sangha region of southwestern Central African Republic. Primate Conservation 7: 38-41.

22. Chivers, D.J. (1987). IPS Conservation Appeal. Primate Eye 33: 11-17.

23. Clark, C.B. (1977). A preliminary report on weaning among Chimpanzees of the Gombe Natonal Park, Tanzania. In: Chevalier-Skolinkoff, S. and Poirier, F.E. (Eds), Primate Bio-social Development: Biological, Social and Ecological Determinants. Garland, New York.

24. Cousins, D. (1978). Gorillas - a survey. Oryx 14: 254-258.

25. Davies, A.G. (1987). The Gola Forest Reserves, Sierra Leone: Wildlife Conservation and Forest Management. IUCN, Gland and Cambridge.

26. Department of Wildlife Management, Sudan (1982). Wildlife Information Booklet. Democratic Republic of the Sudan, Ministry of Wildlife Conservation and Tourism, Southern Region.

27. Dupuy, A.R. and Verschuren, J. (1977). Wildlife and parks in Senegal. Oryx 14(1): 36-46.

28. Estes, R.D. (1983). The Giant Sable and wildlife conservation in Angola. Report to IUCN.

29. Fritz, J. (1986). Resocialization of asocial Chimpanzees. In: Benirschke, K. (Ed.), Primates: The Road to Self-Sustaining Po pulations. Springer-Verlag, London.

30. Gartlan, J.S. and Struhsaker, T.T. (1972). Polyspecific associations and niche separation of rain-forest anthropoids in Cameroon, West Africa. Journal of Zoology 168: 221-226.

31. Ghiglieri, M.P. (1984). The Chimpanzees of Kibale Forest. Columbia University Press, New York.

32. Goodall, J. (1986). The Chimpanzees of Gombe. Belknap/Harvard Press, Cambridge, Mass.

33. Hannah, A.C. and McGrew, W.C. (1987). Chimpanzees using stones to crack open oil palm nuts in Liberia. Primates 28: 31-46.

34. Happold, D.C.D. (1971). A Nigerian High Forest Reserve. In: Happold, D.C.D. (Ed.), Wildlife Conservation in West Africa. IUCN Publications new series No. 22. Pp. 58-59. 
35. Harako, R. (1981). The cultural ecology of hunting behaviour among Mbuti Pygmies in the Ituri Forest, Zaire. In: Harding, R.S.O. and Teleki, G. (Eds), Omnivorous Primates: Gathering and Hunting in Human Evolution. Columbia University Press, New York.

36. Harcourt, A.H. (1983). Note from a corresponding member of the Conservation Working Party on the Nyungwe Forest, Rwanda. Primate Eye 20: 11-12.

37. Harcourt, A.H., Stewart, K.J. and Inaharo, I.H. (1988). Nigeria's gorillas: a survey and recommendations. Unpublished report to the Nigerian Conservation Foundation.

38. Harding, R.S.O. (1984). Primates of the Kilimi area, Sierra Leone. IUCN/SSC Primate Specialist Group Newsletter 4: 32-34.

39. Harrison, M.J.A. (1987). Pers. comm.

40. Harrisson, B. (1971). Conservation of nonhuman primates in 1970. In: Goldsmith, E.I. and Moor-Janowski, J. (Eds), Primates in Medicine. Vol.5. S. Karger, Basel.

41. Hart, J.A. and Thomas, S. (1986). The Ituri forest of Zaire: Primate diversity and prospects for conservation. Primate Conservation 7: 42-43.

42. Hill, W.C.O. (1969). The nomenclature, taxonomy and distribution of Chimpanzees. In: Bourne, G.H. (Ed.), The Chimpanzee. Vol. 1. Anatomy, Behaviour and Diseases of Chimpanzees. S. Karger, Basel and New York.

43. Hiraiwa-Hasegawa, M., Hasegawa, T. and Nishida, T. (1984). Demographic study of a large-sized unit-group of Chimpanzees in the Mahale Mountains, Tanzania: A preliminary report. Primates 25: 401-413.

44. Huntley, B.J. (1974). Outlines of wildlife conservation in Angola. Journal of the South African Wildlife Management Association 4(3): 157-166.

45. IUCN (1986). African Wildlife Laws: IUCN Environmental Policy and Law Occasional Paper No.3. Gland and Cambridge, IUCN.

46. IUCN Conservation Monitoring Centre (1985). IUCN Directory of Afrotropical Protected Areas. IUCN, Cambridge, U.K. and Gland, Switzerland.

47. Jeffrey, S. (1977). How Liberia uses wildlife. Oryx 14(2): 168-173.

48. Jeffrey, S.M. (1974). Primates of the dry high forest of Ghana. Nigerian Field 39(3): $117-127$

49. Johns, A.D. and Skorupa, J.P. (1987). Response of rain-forest primates to habitat disturbance: A review. International Journal of Primatology 8(2): 157-191.

50. Jones, C. and Sabater Pi, J. (1971). Comparative ecology of Gorilla gorilla (Savage and Wyman) and Pan troglodytes (Blumenbach) in Rio Muni, West Africa. Bibliotheca Primatologica 13: 1-96.

51. Kano, T. (1971). Distribution of the primates on the Eastern shore of Lake Tanganyika. Primates $12(3-4): 281-304$

52. Kano, T. (1971). The Chimpanzees of Filabanga, western Tanzania. Primates 12: $229-246$.

53. Kano, T. (1972). Distribution and adaptation of the Chimpanzees on the eastern shore of Lake Tanganyika. Kyoto University African Studies 7: 37-129.

54. Kavanagh, M. and Bennett, E.L. (1984). A synopsis of legislation and the primate trade in habitat and user countries. In: Mack, D. and Mittermeier, R.A. (Eds), International Trade in Primates. TRAFFIC (U.S.A.).

55. Kortlandt, A. (1983). Marginal habitats of Chimpanzees. Journal of Human Evolution 12: 231-278.

56. Kortlandt, A. (1965). Some results of a pilot study on Chimpanzee ecology. Unpublished report. $59 \mathrm{pp}$.

57. Kortlandt, A. (1966). Chimpanzees in vrijheid. Journal of Royal Society Zool. Antwerp 31: 111-116.

58. Kortlandt, A. and van Zon, J.C.J. (1969). The present state of research on the dehumanization hypothesis of African ape evolution. Proceedings of the 2nd International Congress of Primatology. Vol. 3. S. Karger, Basel.

59. Lawick-Goodall, J. van (1968). The behaviour of free-living Chimpanzees in the Gombe Stream Reserve. Animal Behaviour Monographs 1: 161-311.

60. Marsden, S. (1983). Rehabilitating Chimpanzees in Gambia. Fund for Animals (Australia) Newsletter 3(2): 14-15.

61. Martin, C. (1976). WWF Project 1251. Bia National Park, Ghana - Conservation programme B/11/132.1. WWF Progress Report November - December 1976, No.105, P.5. 
62. Matsubayashi, K., Gotoh, S. and Suzuki, J. (1986). Changes in import of non-human primates after ratification of CITES (Washington Convention) in Japan. Primates 27: 125-135.

63. McGrew, W. (1985). In litt.

64. McGrew, W.C., Baldwin, P.J. and Tutin, C.E.G. (1981). Chimpanzees in a hot, dry and open habitat: Mt Assirik, Senegal, West Africa. Journal of Human Evolution 10:227-244.

65. Monfort, A. and Monfort, N. (1973). Quelques observations sur les grands mammifères du Parc National de Tai (Côte d'Ivoire). La Terre et la Vie 27(4): 499-506.

66. Moore J.J. (1985). Report of a brief wildlife survey to Mali. Unpublished report.

67. Moore, J.J. (1985). In litt.

68. Moreau, E. (1942). The distribution of the Chimpanzee in Tanganyika Territory. Tanganyika Notes and Records 14: 52-55.

69. Mshelbwala, J.H. (1987). The Kanyang Gorilla project. Report of the Nigerian Conservation Foundation.

70. Napier, J.R and Napier, P.H. (1967). A Handbook of Living Primates. Academic Press, London and New York.

71. Niedl, M. and Langrand, O. (1986). Conservation et utilization rationnelle des ecosystemes forestiers du Gabon. Report to WWF/IUCN.

72. Nishida, T. (1979). The social structure of Chimpanzees of the Mahale Mountains. In: Hamburg, D.A. and McCown, E.R. (Eds), The Great Apes. Benjamin/Cummings, Manlo Park, California.

73. Nishida, T. (1987). In litt. to W. McGrew.

74. Nishida, T. and Kawanaka, K. (1972). Inter-unit-group relationships among wild Chimpanzees of the Mahali Mountains. Kyoto University African Studies 7: 131-169.

75. Nissen, H.W. (1931). A field study of the Chimpanzee. Comp. Psychol. Monogr. 8: 1-22.

76. Nkosi Luta Kingengo (1982). In litt. to P. Portas, IUCN.

77. Oates, J. (1985). In litt.

78. Oates, J.F. (1985). IUCN/SSC Primate Specialist Group: Action Plan for African Primate Conservation 1986-90. IUCN/WWF, Gland and Washington, D.C.

79. Peal, A. (1979). In litt. to Geza Teleki.

80. Peal, A. (1983). In litt.

81. Petrides, G.A. (1965). Advisory Re port on Wildlife and National Parks in Nigeria 1962. Special Publication No. 18., American Committee for International Wild Life Protection, Bronx, New York, 10460, U.S.A.

82. Prince, A.M. (1985). Rehabilitation and release program for Chimpanzees. Primate Conservation 5: 33.

83. Report of special consulting committee (Members: J.S. Gartlan, C.J. Jones, A. Kortlandt, T.T. Struhsaker) convened by the Interagency Primate Steering Committee of the National Institutes of Health, Washington, D.C., March 1978. International Primate Protection League Newsletter 5(2): 14 (August 1978).

84. Robinson, P.T. and Peal, A. (1981). Liberia's wildlife: The time for decision. ZooNooz 54(10): 7-21.

85. Robinson, P.T. (1971). Wildlife trends in Liberia and Sierra Leone. Oryx 11(2-3): 117-122.

86. Robinson, P.T. (1983). Birth pains for Sapo National Park in Liberia. IUCN/SSC Primate S pecialist Group Newsletter 3: 23-24.

87. Sabater Pi, J. and Groves, C. (1972). The importance of higher primates in the diet of the Fang of Rio Muni. Man 7(2): 239-243.

88. Sabater Pi, J. (1980). In litt.

89. Sabater Pi, J. (1981). Exploitation of Gorillas Gorilla gorilla gorilla Savage and Wyman 1847 in Rio Muni, Republic of Equatorial Guinea, West Africa. Biological Conservation 19(2): 131-140.

90. Sabater Pi, J. and Jones, C. (1967). Notes on the distribution and ecology of the higher primates of Rio Muni, West Africa. Tulane Studies in Zoology 14(3): 101-109.

91. Sayer, J.A. (1977). Conservation of large mammals in the Republic of Mali. Biological Conservation 12: 245-263.

92. Sayer, J.A. and Green, A.A. (1984). The distribution and status of large mammals in Benin. Mammal Review 14(1): 37-50. 
93. Seal, U.S. and Flesness, N.R. (1986). Captive Chimpanzee populations past-present and future. In: Benirschke, K. (Ed.), Primates: The Road to Self-Sustaining Populations. Springer-Verlag, London.

94. Skorupa, J.P. (1986). Responses of rain-forest primates to selective logging in Kibale Forest, Uganda: A summary report. In: Benirschke, K. (Ed.), Primates: The Road to Self-Sustaining Po pulations. Springer-Verlag, London.

95. Spinage, C. (1985). Pers. comm.

96. Spinage, C.A. (1980). Parks and reserves in Congo Brazzaville. Oryx 15(3): 292-295.

97. Stewart, K.J. \& Harcourt, A.H. (1987). In litt.

98. Struhsaker, T.T. (1987). Forestry issues and conservation in Uganda. Biological Conservation 39: 209-234.

99. Struhsaker, T.T. (1975). The Red Colobus Monkey. University of Chicago Press, Chicago.

100. Struhsaker, T.T. (1981). Forest and primate conservation in East Africa. African Journal of Ecology 19: 99-114.

101. Sugiyama, Y. (1984). Population dynamics of wild Chimpanzees at Bossou, Guinea, between 1976-1983. Primates 25: 391-400.

102. Sugiyama, Y. and Koman, J. (1979). Social structure and dyramics of wild Chimpanzees at Bossou, Guinea. Primates 20(3): 323-339.

103. Suzuki, A. (1969). An ecological study of Chimpanzees in a savanna woodland. Primates 10: $103-148$.

104. Suzuki, A. (1971). Carnivority and cannibalism observed among forest-living Chimpanzees. Journal of the Anthropological Society of Nippon 79(1): 30-48.

105. Suzuki, A. (1971). On the problems of conservation of the Chimpanzees in East Africa and the preservation of their environment. Primates 12: 415-418.

106. Tappen, N.C. (1964). Primate studies in Sierra Leone. Current Anthropology 5(4): 339-340.

107. Teleki, G. (1978). A summary of scientific evidence pertaining to the application of Merck, Sharp and Dohme Research Laboratories for a permit to import 125 Chimpanzees (Pan troglodytes) from Sierra Leone. Unpublished report to the Office of Endangered Species, United States Department of the Interior, Washington, D.C., March 16, 1978.

108. Teleki, G. (1987). Current threats to the survival of Chimpanzees (Pan troglodytes) in Equatorial Africa. Unpublished report by the Committee for Conservation and Care of Chimpanzees, Washington, D.C.

109. Teleki, G. (1980). Hunting and trapping wildlife in Sierra Leone: Aspects of exploitation and exportation. Unpublished report.

110. Teleki, G. (1981). The omnivorous diet and eclectic feeding habits of Chimpanzees in Gombe National Park, Tanzania. In: Harding, R.S.O. and Teleki, G. (Eds), Omnivorous Primates: Gathering and Hunting in Human Evolution. Columbia University Press, New York.

111. Teleki, G. and Baldwin, L. (1979). Known and estimated distributions of extant Chimpanzee populations (Pan troglodytes and Pan paniscus) in Equatorial Africa. Special report to the IUCN/SSC Primate Specialist Group, June 1979.

112. Teleki, G. and Baldwin, L. (1979). The need for a systematic survey of Chimpanzee populations in West Africa, focusing initially on the Republic of Sierra Leone. Unpublished report to the IUCN/SSC Primate Specialist Group.

113. Teleki, G. and Baldwin, L. (1975). Breeding programs aim to keep this a planet of the Apes. Smithsonian 5: 76-81.

114. Teleki, G. and Baldwin, L. (1981). Sierra Leone's wildlife legacy: Options for survival. ZooNooz 54(10): 21-27.

115. Teleki, G., Hunt, E.E. and Pfifferling, J.H. (1976). Demographic observations (1963-1973) on the Chimpanzees of Gombe National Park, Tanzania. Journal of Human Evolution 5: 559-598.

116. Tutin, C.E.G. and Fernandez, M. (1984). Nationwide census of Gorilla (Gorilla g. gorilla) and Chimpanzee (Pant.troglodytes) populations in Gabon. American Journal of Primatology 6: 313-336.

117. Tutin, C.E.G. and Fernandez, M. (1983). Gorilla and Chimpanzee census in Gabon. IUCN/SSC Primate S pecialist Group Newsletter 3: 22-23. 
118. Tutin, C.E.G., McGrew, W.C. and Baldwin, P.J. (1983). Social organization of savanna-dwelling Chimpanzees, Pan troglodytes verus, at Mt. Assirik, Senegal. Primates 24(2): 154-173.

119. Vandebroek, G. (1958-59). Notes ecologiques sur les anthropoides Africains. Annales Société Royale Zoologique de Belgique 89:203-211.

120. Vedder, A. (1986). Deals with the Devil? Bilateral and multilateral aid agencies and primate conservation in Rwanda. Primate Report 14: 156.

121. Verschuren, J. (1975). Wildlife in Zaire. Oryx 13(2): 149-163.

122. Verschuren, J. (1978). Burundi and wildlife: Problems of an overcrowded country. Oryx 14(3): 237-240.

123. Verschuren, J. (1978). Les grands mammifères du Burundi. Mammalia 42(2): 209-224.

124. Verschuren, J. (1981). Relance de la Conservation de la Nature. Faune, Flore, Reserves Naturelles. Report produced for the Ministere des Eaux et Forêts Brazzaville, Republique Populaire du Congo.

125. Verschuren, J.C. (1982). Recherches scientifiques dans les parcs nationaux du Sénégal. XIX. Notes de Bio-écologie des grands mammifères du Parc National du Niokolo-Koba. Examen comparé avec le Zaire et l'Afrique de l'est. Mémoires de l'Institut Fondamental d'Afrique Noire. No. 92.

126. White, F.J. and Susman, R.L. (1986). Program for the confiscation and protection of contraband Pygmy and Common Chimpanzees in the Republic of Zaire. Primate Conservation 7:59-60.

127. Wolfheim, J.H. (1983). Primates of the World, their: Distribution, Abundance, and Conservation. University of Washington Press, Seattle and London.

128. Wrangham, R.W. (1986). Ecology and social relationships in two species of Chimpanzee. In: Rubenstein, D.I. and Wrangham, R.W. (Eds), Ecological Aspects of Social Evolution. Princeton University Press, New Jersey.

129. Wrangham, R.W. (1977). Feeding behaviour of Chimpanzees in Gombe National Park, Tanzania. In: Clutton-Brock, T.H. (Ed.), Primate Ecology: Studies of Feeding and Ranging Behaviour in Lemurs, Monkeys and Apes. Academic Press, London.

130. Yerkes, R.M. (1943). Chimpanzees. A Laboratory Colony. Louis Stern Memorial Fund. 



\section{Threatened Primates of Africa}

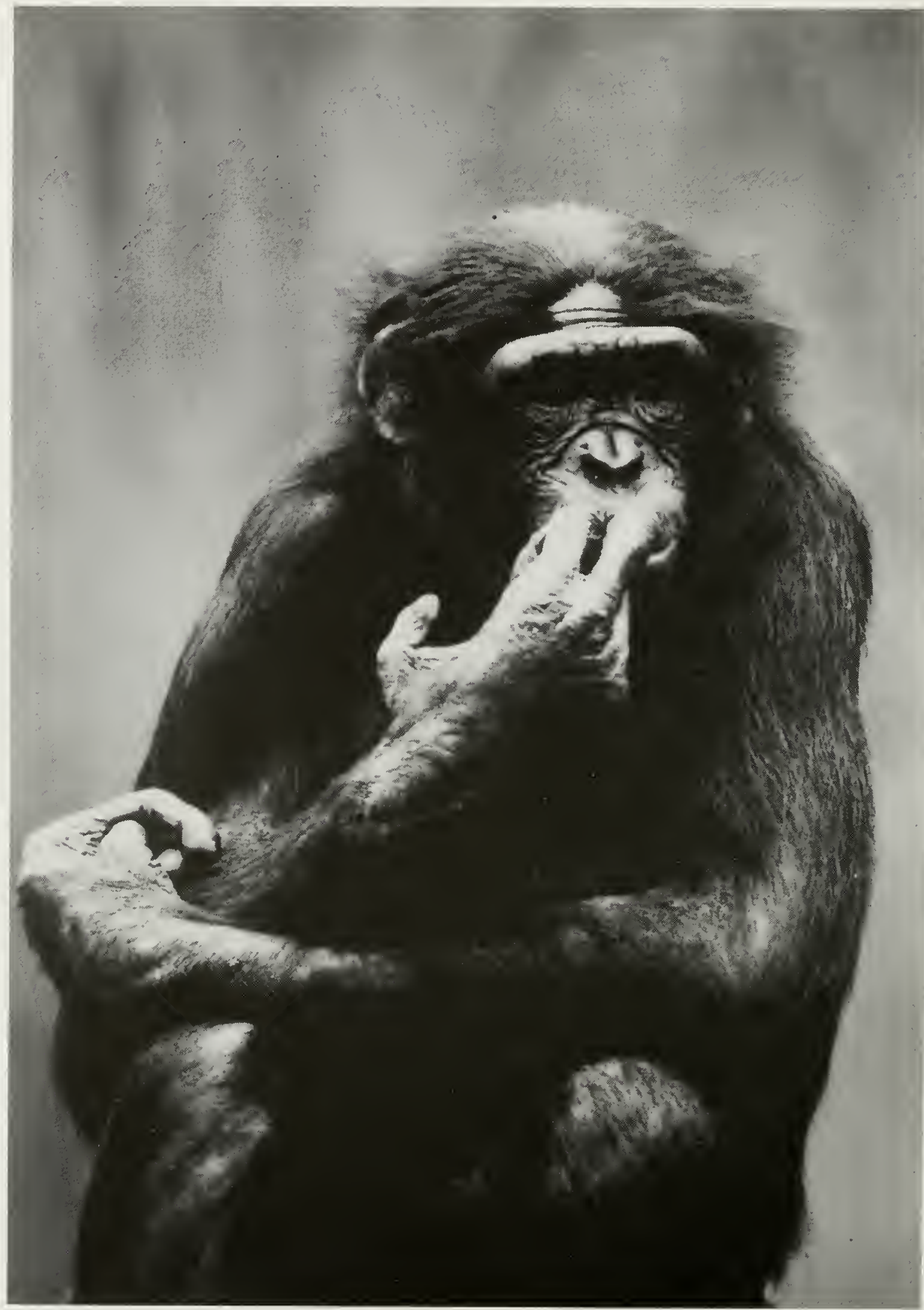

The Pygmy Chimpanzee Pan paniscus is found only south of the Zaire River in the central Zaire rain forests. No protected areas contain the species and it is threatened by habitat loss in its restricted range.

Photo by Russell A. Mittermeier, WWF-US. 
The IUCN Red Data Book

VULNERABLE

Pan paniscus Schwarz, 1929

Order PRIMATES

Family PONGIDAE

SUMMARY The Pygmy Chimpanzee has a discontinuous distribution in the central Zaire basin and is found only south of the Zaire River. Although extensive areas (350 $000 \mathrm{sq} \cdot \mathrm{km}$ ) of potential habitat are found in the region, Pygmy Chimpanzees are known from only a few scattered locations. Total numbers are essentially unknown; estimates range from 15000 to 200000 with little reliable data. The species depends on fruit and lives in fluid communities. It is hunted for meat and for religious purposes, but the main threats come from habitat loss due to increasing slash and burn cultivation and commercial logging operations. Although protected by law, enforcement is negligible. Salongo National Park was established to help conserve Pygmy Chimpanzees, but does not appear to contain a sizeable population. The establishment of parks and reserves in areas of high Pygmy Chimpanzee densities is an urgent conservation requirement. Surveys to determine distribution and abundance are also needed. The Bonobo breeds well in captivity. It is listed in Class A of the African Convention and in Appendix 1 of CITES.

DISTRIBUTION Pan paniscus occurs in the central Zaire Basin, between the Zaire River $\left(2^{\circ} \mathrm{N}\right)$, the Lomami River $\left(24^{\circ} \mathrm{E}\right)$, the Kasai/Sankuru Rivers $\left(4^{\circ} \mathrm{S}\right)$ and Lake Tumba/Lac Ndombe area $\left(18^{\circ} \mathrm{E}\right)(2,3,10,35,40,64)$. It appears to be absent from the central part of this area between the Momboyo River and the Busira River $(32,64)$. Suggestions that the range extends east to the Lualaba River and the headwaters of the Zaire River remain unconfirmed $(53,56)$. It was orginally suggested that its range was continuous $(10,16,38,71)$, but field observations have found the species absent or rare in many areas, and common only in a few scattered localities $(2,3,6,35,56)$. Few field studies were carried out prior to the 1970s since few Pygmy Chimpanzees could be located in those areas where they were thought to occur. Studies in the last decade have confirmed viable populations only near the towns of Befale, Djolu, Bokungu and Ikela, and in a 3000 sq.km area between the Yekokora and Lomako Rivers $(2,3,4,18,26,33,35,40,56)$. For a map, see $(50)$.

POPULATION No reliable estimates of total numbers are yet available. Speculative estimates based on extrapolations of Common Chimpanzee (Pan troglodytes) densities to areas of Pygmy Chimpanzee habitat suggest a total of between $100000-200000$ (31). However, estimates of numbers from known localities where field studies have been made suggest that a maximum of 13000 survive in all areas of potential habitat (60). Even if the unsurveyed forests of central Zaire contain dispersed Pygmy Chimpanzee communities, total numbers would probably rise only by a few thousand (60) (when applying demographic parameters from $P$. troglodytes to areas of potential habitat and taking into account variation in forest type and hunting pressures which are significant in central Zaire) $(2,14,35,40,45,46,74)$. Densities are given only for two study sites and are 2-3 animals per sq. km (67). Essentially, total numbers of Pygmy Chimpanzees are unknown and further studies on density and distribution are required.

HABITAT AND ECOLOGY The species utilizes a variety of forest types including primary and secondary forests $(35,2,4,6,13,18,20,26,29,33,34,40,64)$ and occasionally ranges into seasonally innundated swamp forest (1). While an optimal habitat cannot yet be identified, high densities are known fromsecondary forest on dry ground $(17,26,40)$. In some wet localities, e.g. the Lake Tumba area, seasonal nomadism can be extensive $(18,40)$. Community ranges vary in size from area to area $(33,34)$, and are between $22 \mathrm{sq.km}$ in Lomako to $50 \mathrm{sq} . \mathrm{km}$ in Wamba (67). Terrestrial travel is common and Bonobos are not averse to wading through shallow water $(2,4,17,18,34,35)$. Foraging and feeding are both terrestrial and arboreal (57). Feeding occupies about $30 \%$ of the day (67), with fruit comprising the majority of the dict while leaves, pith, flowers, seeds and invertebrates are also eaten $(5,6,20,29)$. Fiberous plant foods appear to be important when fruits are seasonally scarce $(1,39,67)$. Pygmy Chimpanzees have also been observed to eat small mammals $(67,75)$. Sleeping nests are built in trees, typically at $20 \mathrm{~m}$ above the ground $(2,3,20,29,35,40)$. 
Social structure is based on fluid communities of 30-80 (or as many as 120 (67)) animals $(26,33,34,40,64)$, that split into foraging groups often containing more than six animals $(2,6,26,33,34,35,40,53,56,67)$. Adult males sometimes travel alone $(33,34,40)$ and thus are more susceptible to hunting and trapping $(33,34)$. Foraging parties tend to contain animals of both sexes $(1,39,67)$, with long-term associations between females (1) and possibly between males (67). Reproductive parameters are still poorly known, but a late age at first reproduction of 13-14 years and a long inter-birth interval of 3-7 years (67) suggest that, like the Common Chimpanzee, they reproduce very slowly in the wild (62).

THREATS The greatest threats to Pan paniscus are habitat loss $(3,67)$ and hunting $(24)$. Some may be captured for local trade or for export for biomedical research $(67,69)$.

While habitat loss was not a threat prior to the 1970s, increasing human population pressures were forcing Pygmy Chimpanzee to retreat into remote forest areas by the 1980 s $(3,55,56)$. Traditional methods of slash and burn agriculture and commercial forestry are intensifying in central Zaire $(2,35,56)$, eliminating habitats especially near villages and roads $(2,26)$. However, secondary forests can be used by the species $(33,34,35,40)$, occasionally with an increase in density in the absence of hunting pressures (29). When the habitat is disturbed, Pygmy Chimpanzees tend to leave the region; only in a few places such as Wamba can they coexist with humans (56).

Commercial logging also poses a threat. In 1981, a multinational company, Karl Danzer Furnier-Werk, acquired the logging rights to an area that largely corresponds with the species' range, and logging operations began in the Lomako tract containing one of the two study sites for Pygmy Chimpanzees $(6,56)$. In 1984, Susman and Mubalamata noted that they were encouraged by efforts to remove an area of undisturbed forest from logging; an area of some $500 \mathrm{sq.km}$ bordered by the Lomako and its watershed to the north (55). Susman states that the company had "pulled back reducing the threat to the Lomako" (51). At the Wamba study site, logging was a threat (56), but the area may now be safer from imminent deforestation (55).

Subsistence hunting for meat $(3,40,55,65)$, and commercial hunting of bushmeat to supply large labour forces employed by companies in the area, are both widespread in central Zaire $(40,56,65)$. Pygmy Chimpanzees (and other primates) are prized prey $(2,26,35,40,56)$. Around Wamba, hunting apes is taboo (34) and the species is not hunted near Yalosidi (29). However, hunting pressure may be an important factor in the patchiness of Pygmy Chimpanzee distributions (2). The species is especially vulnerable to the increasing use of firearms, since they flee into trees and can be surrounded $(2,3,4,40,56)$. They are occasionally hunted for medicinal or magical purposes, since specific body parts are thought to enhance strength and sexual vigour $(2,3,40,55)$. Such charms are widely available in some areas, suggesting that large numbers of Pygmy Chimpanzees may be killed annually (40).

Infant Pygmy Chimpanzees are captured by killing the mother, and are kept as pets $(2,3,55,56)$ or presented as gifts to visiting dignitaries (2). While the threat that the species could become a popular species for laboratory biomedical research $(12,22,37,44,59,66,72)$, has yet to materialize (30), the species is illegally traded with European countries (especially Belgium) and the Far East (55). Infants and juveniles are currently sold to zoological gardens, laboratories in Europe and Asia, and for the pet trade $(24,55,69)$. Hunting activity is especially severe in the lower Equateur region, where it is a highly profitable activity (24).

CONSERVATION MEASURES The Pygmy Chimpanzee is the only great ape not yet adequately protected in a national park or reserve $(2,4,18,26,33,34,35,40)$; the Salonga National Park established in part for its protection $(2,3,40)$ does not apparently harbour sizeable numbers of Pygmy Chimpanzees comparable to areas such as Lomako or Wamba $(2,3,26,54,56)$. The most urgently required conservation measure is therefore the establishment of at least one park or reserve specifically to protect the species $(35,54,56)$ following a comprehensive survey of Equateur. The Lomako Forest, which is the site of a long term Pygmy Chimpanzee study, has been suggested as a possible site. The area contains a reasonably large and viable Pygmy Chimpanzee population, has a good forest cover, is remote, with an area of $3100 \mathrm{sq.km}$ bounded by rivers, and has a low human population density. The local people, who only sporadically enter 
the forest, use traditional weapons for hunting game and do not kill Pygmy Chimpanzees $(2,3,4,23,5154)$. This area was also proposed as a national park in 1976 by Dr Kabala Matuka because of its unique flora and fauna (23). A survey is also urgently required to pinpoint remnant populations with the best survival potential.

The species is protected by law throughout Zaire $(2,3,34)$ but in practice there is no enforcement $(2,4)$. By 1984 efforts to curtail illegal export had been increased $(55,69)$. Major efforts to reduce hunting are also necessary. Conservation education programmes to alert local residents to the devastating effects of hunting on primate populations should be initiated throughout the range of species.

Several field studies have been conducted $(35,2,4,26,7,40,17,18,3,6,13,15,20,28, \quad 29$, $33,34,53,56,57$ ), but only two long term studies have been successful (Kano, 1982 et seq. and Susman, $1984(50)$ ). Captive behavioural studies are underway $(21,42,43,63,70)$. Two principal study sites exist - the Lomako Forest, and Wamba $(6,34,36)$. At both sites there are long-term study projects: at Lomako principally by students from the State University of New York at Stony Brook under the auspices of the Institut de Recherche Scientifique (I.R.S.), Kinshasa (55); at Wamba principally by Japanese workers from the University of the Ryukyus and also under the auspices of the I.R.S. The species has also been studied near Lake Tumba (20), and at Yalosidi (29).

Plans are underway for a comprehensive conservation programme consisting of: i) Confiscation in Zaire of contraband animals and their housing in local animal parks; and ii) a systematic survey of Pan paniscus in Central Zaire in order to establish a reserve area $(52,69)$.

The Pygmy Chimpanzee is listed in Class A of the African Convention, (1969); it may be hunted, killed, captured or collected only on the authorization of the highest competent authority, if required in the national interest or for scientific purposes.

The species is also included in Appendix 1 of the 1973 Convention on International Trade in Endangered Species of Wild Fauna and Flora (CITES), and therefore any trade in it or its products is subject to strict regulation by ratifying nations, and trade for primarily commercial purposes is banned.

CAPTIVE BREEDING In 1984 there were 25 males and 32 females ( 28 captive bred) held in eleven zoological collections (41). The studbook is maintained by B. Van Puijenbroeck at Antwerp Zoo, Koningen Astridplein 26, B-2000, Antwerp, Belgium (41). Numbers held in laboratory colonies and their breeding success are not known.

REMARKS For a description of the species see $(2,3,9,10,16,38)$. The taxonomic affinity between $P$. paniscus and $P$. troglodytes is still under review $(8,11,19,48,72,73)$ and several authors advocate separation only at the subspecific level $(19,48)$. Accounts exist that in some areas the two species are sympatric, however this remains unconfirmed (56).

This data sheet was compiled with the assistance of Geza Teleki and benefited greatly from his 1979 report to the IUCN/SSC Primate Specialist Group.

\section{REFERENCES}

1. Badrian, N. and Malenky, R. (1984). Feeding ecology of Pan paniscus in the Lomako Forest, Zaire. In: Susman, R.L. (Ed.), The Pygmy Chimpanzee: Evolutionary Biolgy and Behaviour. Plenum Press, New York.

2. Badrian, A. and Badrian, N. (1977). Pygmy Chimpanzees. Oryx 13(5): 463-468.

3. Badrian, A. and Badrian, N. (1980). The other Chimpanzee. Animal Kingdom 83(4): 8-14.

4. Badrian, A. and Badrian, N. (1978). Wild Bonobos of Zaire. African Wildlife Leadership Foundation Wildlife News 13: 12-16.

5. Badrian, N. and Malenky, R. (1982). Feeding and ranging behaviour of Pan paniscus in the Lomako Forest. Paper presented to the 9th Congress of the International Primate Society, Atlanta, Georgia. 
6. Badrian, N., Badrian, A. and Susman, R.L. (1981). Preliminary observations on the feeding behaviour of Pan paniscus in the Lomako Forest of Central Zaire. Primates 22(2): 173-181.

7. Baldwin, L.A. and Teleki, G. (1973). Field research on Chimpanzees and Gorillas: An historical, geographical and bibliographical listing. Primates 14(2-3): 315-330.

8. Bone, E.L. and Haumont, S. (1969). The International Primatological Center in west central Africa. Proceedings of the 2nd International Congress of Primatology, Atlanta, Georgia. Vol. 2. S. Karger, Basel.

9. Coolidge, H.J. and Shea, B.T. (1982). External body dimensions of Pan paniscus and Pan troglodytes Chimpanzees. Primates 23(2): 245-251.

10. Coolidge, H.J., Jr. (1933). Pan paniscus. (Pigmy Chimpanzee) from south of the Congo River. American Journal of Physical Anthropology 8(1): 1-57.

11. Cronin, J.E. (1977). (Pygmy Chimpanzees) (Pan paniscus) systematics. American Journal of Physical Anthropology 47(1): 125.

12. Goldsmith, E.I. and Moor-Janowski, J. (1978). Some aspects of the proposed captive breeding of Dwarf Chimpanzees (Pan paniscus). Journal of Medical Primataology 7: 65-69.

13. Hansinger, M.J., Simons, E.L., Pilbean, D.R., Horn, A.D., and Gartlan, J.S. (1974). The 1972 field study of the Pygmy Chimpanzee (Pan paniscus) in central Africa. American Journal of Physical Anthro pology 40: 139.

14. Harrisson, B. (1971). Conservation of Nonhuman Primates in 1970. In: Goldsmith, E.I. and Moor-Janowski, J. (Eds), Primates in Medicine. Vol. 5. S. Karger, Basel.

15. Hasegawa, H., Kano, T. and Molavwa, M. (1983). A parasitological survey of the feces of Pygmy Chimpanzees, Pan paniscus, at Wamba, Zaire. Primates 24(3): 419-423.

16. Hill, W.C.O. (1969). The nomenclature, taxonomy and distribution of Chimpanzees. In: Bourne, G.H. (Ed.), The Chimpanzee. Vol. 1. Anatomy, Behaviour, and Diseases of Chimpanzees. S. Karger, Basel.

17. Horn, A.D. (1975). Adaptations of the Pygmy Chimpanzee (Pan paniscus) to the forests of the Zaire basin. American Journal of Physical Anthropology 42(2): 307.

18. Horn, A.D. (1977). A preliminary report on the ecology and behaviour of the Bonobo Chimpanzee, Pan paniscus Schwarz, 1929, and a reconsideration of the evolution of the Chimpanzee. Ph.D thesis, Yale University, New Haven.

19. Horn, A.D. (1979). The taxonomic status of the Bonobo Chimpanzee. American Journal of Physical Anthro pology 51(2): 273-282.

20. Horn, A.D. (1980). Some observations on the ecology of the Bonobo Chimpanzee (Pan paniscus, Schwarz 1929) near Lake Tumba, Zaire. Folia Primatologica 34(3-4): 145-169.

21. Hübsch, I. (1970). Eineges zum verhalten der zwergschimpanzen (Pan paniscus) und der schimpansen Pan troglodytes in Frankfurter Zoo. Der Zoologische Garten 38 (3/4): 107-132.

22. International Primate Protection League correspondence files on agreements between Yerkes Regional Primate Research Center (YRPRC) and Institut pour la Recherche Scientifique en Afrique Centrale (IRSAC) to export Bonobos to the U.S.A. for biomedical research.

23. Kabala, M. (1976). Aspects de la Conservation de la Nature. Edition Lokole, Kinshasa.

24. Kabongo, K.M. (1984). Will the Pygmy Chimpanzee be threatened with extinction like the elephant and the white rhinoceros in Zaire? In: Susman, R.L. (Ed.), The Pygmy Chimpanzee: Evolutionary Biology and Behaviour. Plenum Publishing Corporation, New York.

25. Kano, T. (1984). Distribution of Pygmy Chimpanzees (Pan paniscus) in the central Zaire basin. Folia Primatologia 43: 36-52.

26. Kano, T. (1979). A pilot study on the ecology of Pygmy Chimpanzees (Pan paniscus). In: Hamburg, D.A. and McCown, E.R. (Eds), The Great Apes. Benjamin/Cummings, Menlo Park.

27. Kano, T. (1980). Social behaviour of wild Pygmy Chimpanzees at Wamba: A preliminary report. Journal of Human Evolution 9: 243-260.

28. Kano, T. (1982). The social group of Pygmy Chimpanzees (Pan paniscus) of Wamba. Primates 23(2): 171-188.

29. Kano, T. (1983). An ecological study of the Pygmy Chimpanzees (Pan paniscus) of Yalosidi, Republic of Zaire. International Journal of Primatology 4(1): 1-31. 
30. Kavanagh, M. and Bennett, E.L. (1984). A synopsis of legislation and the primate trade in habitat and user countries. In: Mack, D. and Mittermeier, R.A. (Eds), International Trade in Primates. TRAFFIC (U.S.A.).

31. Kortlandt, A. (1976). Letters: Statements on Pygmy Chimpanzees. Laboratory Primate Newsletter 15(1): 15-17.

32. Kortlandt, A. and Van Zon, J.C. (1969). The present state of research on the dehumanisation hypothesis of african ape evolution. Proceedings of the 2nd International Congress of Primatology, Atlanta, Georgia. Vol. 3. S. Karger, Basel.

33. Kuroda, S. (1976). Ecological and sociological study of Pygmy Chimpanzees in Wamba District. Journal of the Anthropological Society of Nippon 84: 309-310.

34. Kuroda, S. (1979). Grouping of the Pygmy Chimpanzees. Primates 20(2): 161-183.

35. MacKinnon, J. (1976). Mountain Gorillas and Bonobos. Oryx 13(4): 372-382.

36. Malenky, R. (1982). Natural history of the Lamako study site. Paper presented to the 9 th Congress of the International Primate Society, Atlanta, Georgia.

37. McHenry, H.M. and Corruccini, R.S. (1981). Pan paniscus and human evolution. American Journal of Physical Anthro pology 54(3): 355-367.

38. Napier, J.R. and Napier, P.H. (1967). A Handbook of Living Primates. Academic Press, London and New York.

39. Nishida, T. and Hiraiwa-Hasegawa, M. (1987). Chimpanzees and Bonobos: Cooperative relationships among males. In: Smuts, B.B., Cheney, D.L., Seyfarth, R.M., Wrangham, R.W. and Struhsaker, T.T. (Eds), Primate Societies. University of Chicago Press, Chicago.

40. Nishida, T. (1972). Preliminary information of the Pygmy Chimpanzees (Pan paniscus) of the Congo Basin. Primates 13(4): 415-425.

41. Olney, P.J.S. (Ed.) (1986). International Zoo Yearbook 24/25. Zoological Society of London.

42. Patterson, T. (1979). The behaviour of a group of captive Pygmy Chimpanzees (Pan paniscus). Primates 20(3): 341-354.

43. Rempe, U (1961). Einiege beobachtungen an Bonobos, Pan paniscus. Z. f. Wiss. Zool. 165: 81-87.

44. Report of the task force on the use of and need for Chimpanzees. National Institutes of Health, Bethesda, MD, July 1978.

45. Sabater Pi, J. (1979). Chimpanzees and human predation in Rio Muni. International Primate Protection League Newsletter 6(2): 8.

46. Sabater Pi, J. and Groves, C.P. (1972). The importance of the higher primates in the diet of the Fang of Rio Muni. Man 7: 239-243.

47. Schouteden, H. (1930). Le Chimpanze de la rive gauche du Congo. Bull. Cercle. Zool. Congolais 7 : 114-119.

48. Schultz, A. H. (1969). The skeleton of the Chimpanzee. In: Bourne, G.H. (Ed.), The Chimpanzee. Vol. 1. Anatomy, Behaviour, and Diseases of Chimpanzees. Karger, Basel.

49. Schwarz, E. (1929). Das Vorkommen des Schimpansen auf den linken Kongo-Ufer. Rev. Zool. Bot. Afr. 16(4): 425-433

50. Susman, R. L. (1984). The Pygmy Chimpanzee: Evolutionary Biology and Behaviour. Plenum Publishing Corporation, New York.

51. Susman, R. L. (1985). In litt.

52 Susman, R. L. (in press). Conservation strategy for the Pygmy Chimpanzee in Zaire. IUCN/SSC Primate Specialist Group Newsletter.

53. Susman, R. L. (1980). Acrobatic Pygmy Chimpanzees. Natural History 89(9): 32-38.

54. Susman, R. L. and Badrian, N. (1982). A proposed protected area for the Pygmy Chimpanzee in Zaire. IUCN/SSC Primate S pecialist Group Newsletter 2: 18.

55. Susman, R.L. and Mubalamata, K.K. (1984). Update on the Pygmy Chimp in Zaire. IUCN/SSC Primaie S pecialist Group Newsletter 4: 34-36.

56. Susman, R.L., Badrian, N., Badrian, A. and Handler, N.T. (1981). Pygmy Chimpanzees in peril. Oryx 16 (2): 179-183.

57. Susman, R.L., Badrian, N.L. and Badrian, A.J. (1980). Locomotor behaviour of Pan paniscus in Zaire. American Journal of Physical Anthro pology 53(1): 69-80.

58. Tanaka, J. (1978). A study of the comparative ecology of African gatherer-hunters with special reference to San (Bushman-speaking peoples) and Pygmies. Senri Ethnol. Stud. 1: $189-212$. 
59. Teleki, G. (1978). A summary of scientific evidence pertaining to the application of Merck, Sharp and Dohme Research Laboratories for a permit to import 125 Chimpanzees (Pan troglodytes) from Sierra Leone. Unpublished report to the Office of Endangered Species, U.S. Dept. of Interior, Washington, D.C., March 16, 1978.

60. Teleki, G. and Baldwin, L.A. (1979). Known and estimated distributions of extant Chimpanzee populations (Pan troglodytes and Pan paniscus) in Equatorial Africa. Special report for the IUCN/SSC Primate Specialist Group, June 1979.

61. Teleki, G. and Baldwin, L. (1975). Breeding programs aim to keep this a planet of the apes. Smithsonian 5: 76-81.

62. Teleki, G., Hunt, E.E. and Pfifferling, J.H. (1976). Demographic observation (1963-1973) on the Chimpanzees of Gombe National Park, Tanzania. Journal of Human Evolution 5: 559-598.

63. Tratz, E.P. and Heck, H. (1954). Der afrikanische anthropoide "Bonobo", keine neue menschenaffengattung. Säugetierkunde Mitteilungen 2: 97-101.

64. Vandebroek, G. (1958-59). Notes ecologiques sur les anthropoides africains. Annales Sociéte Royale Zoologique Belgique 89: 203-211.

65. Verschuren, J. (1975). Wildlife in Zaire. Oryx 13(2): 149-163.

66. Wade, N. (1978). New vaccine may bring man and Chimpanzee into tragic conflict. Science 200: 1027-1030.

67. White, F.J. (1986). Behavioral Ecology of the Pygmy Chimpanzee. Ph.D. Thesis, State University of New York, Stony Brook.

68. White, F.J. and Susman, R.L. (1986). Program for the confiscation and protection of contraband Pygmy and Common Chimpanzees in the Republic of Zaire. Primate Conservation 7: 59-60.

69. Wrangham, R.W. (1986). Ecology and social relationships in two species of Chimpanzee. In: Rubenstein, D.I. and Wrangham, R.W. (Eds), Ecological Aspects of Social Evolution. Princeton University Press, Princeton.

70. Yerkes R.M. and Learned, B.W. (1925). Chimpanzee Intelligence and its Vocal Expression. Williams and Wilkins, Baltimore.

71. Yerkes, R.M. (1943). Chimpanzees: A Laboratory Colony. Yale University Press, New Haven.

72. Zihlman, A.L., Cronin, J.E. and Sarich, V.M. (1978). Pygmy Chimpanzee as a possible prototype for the common ancestor of Humans, Chimpanzees, and Gorillas. Nature (London) 275: 744-745.

73. Zilhman, A.L. and Cramer, D.L. (1978). Skeletal differences between Pygmy (Pan paniscus) and Common Chimpanzees (Pan troglodytes). Folia Primatologica 29: 86-94. 


\section{Threatened Primates of Africa}

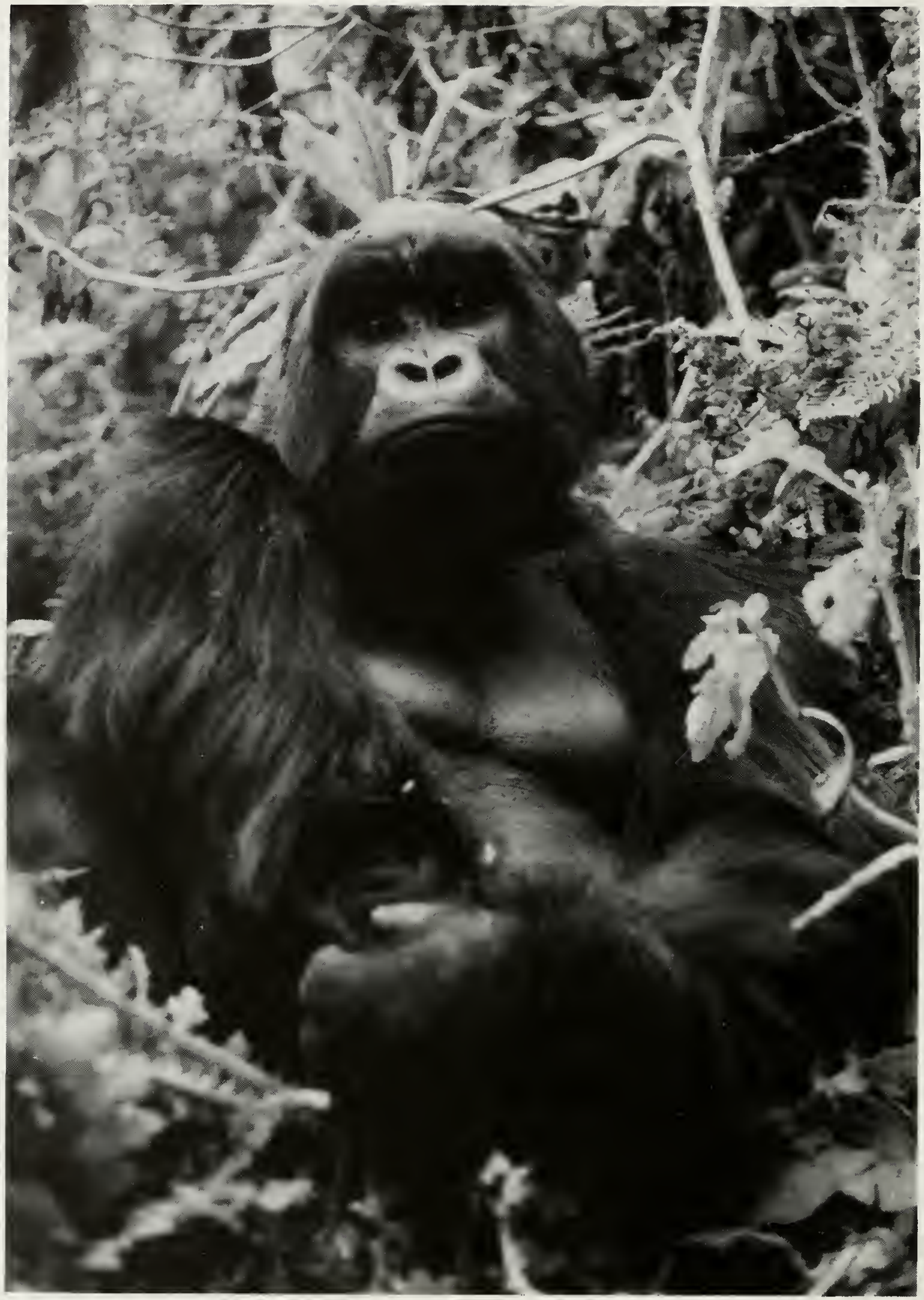

The Mountain Gorilla Gorilla gorilla berengei lives only in the Virunga Volcanoes region of Zaire, Uganda and Rwanda. Extensive conservation efforts during the past 20 years have reversed declines in the population which now numbers between $370-440$ animals.

Photo by R. Weyerhauser . 
The IUCN Red Data Book

GORILLA

VULNERABLE

Gorilla gorilla Savage and Wyman, 1847

Order PRIMATES

Family PONGIDAE

SUMMARY Gorillas occur in two regions of Africa - Equatorial West Africa and East Central Africa, the two areas being separated by the $1000 \mathrm{~km}$ of the Congo Basin tropical forest. Three subspecies are now usually recognised $(40,41)$. The Western Lowland Gorilla (G. g. gorilla) from Cameroon, the south-west corner of the Central African Republic, north-west, central west and south-west Congo (Brazzaville), in much of Rio Muni (Equatorial Guinea) and Gabon $(8,15,31,65,71,78,79,85,86,87,93,96)$, and in Angola in the Cabinda enclave which is north of the Zaire River $(62,68,73)$. Small numbers are found in south-east Nigeria $(31,59,70)$, but the species may be extinct in the Mayumbe District of Zaire just north of the mouth of the Zaire River (90). The Eastern Lowland Gorilla (G. g. graueri) occurs in eastern Zaire. The Mountain Gorilla (G. g. beringei) is found in the Virunga Volcanos region of Rwanda, Uganda and Zaire, and in the Bwindi Forest Reserve of Uganda $(7,23,24,39,81,84)$. Earlier this century Gorillas could also be found in the northern Congo basin, north of the Uele River in the vicinity of the town of Bondo $(1,14,23,39,81)$ but have, as far as is known, become extinct (81).

Little detailed knowledge exists of Gorilla numbers, and details of their distribution in Zaire and Congo (Brazzaville) are largely unknown. Western Gorilla population numbers are tentatively estimated at least $35000-45000$, the majority occurring in Gabon where a nationwide census undertaken between December 1980 and February 1983 suggested a total of $35000 \pm 7000$ $(85,86,87)$. This figure for Gabon, and hence for the Western Lowland population in general, is far higher than earlier estimates (e.g. 1980 estimate for Gabon of 5000-7500 (31)) because: i) Gorillas occur in almost all types of forest including primary forest, and are at higher densities in primary forest than had been previously thought; and ii) the geographical distribution of Gorillas in Gabon covers a greater area than previously known $(85,87)$. Given the finding that Gorillas do in fact occur in primary forest, albeit at low density, and that much of this habitat is still intact in Congo (Brazzaville) and Rio Muni (Equatorial Guinea), the total estimate for the Western Lowland Gorilla could be even higher. The Eastern Lowland Gorilla is thought to be about 3000-5000, and the highly "Endangered" Mountain Gorilla between 370-440, 95-130 in the Bwindi Forest Reserve, and $280-300$ in the Virunga Volcano region $(4,58,89)$.

Forest clearance for agriculture and commercial logging (the wood usually going for export) and hunting for food are factors which adversely affect Gorillas and are likely to increase as human numbers rise $(15,16,18,19,20,21,23,24,31,38,47,49,60,67,79)$. Already Gorilla distribution has been reduced in many countries such as Nigeria and Cameroon and this restriction of range will undoubtedly continue. Early big-game hunting and collecting for scientific purposes are unlikely to have ever posed a major threat. A number of Gorillas, especially infants, are annually captured for sale abroad $(8,16,55,79)$. However, the numbers currently involved are small, and since capturing is usually a side effect of hunting for other reasons, the export market is rarely a major threat except perhaps in Uganda (50).

Of the five countries containing substantial Gorilla populations, only Gabon and perhaps Rio Muni have harboured stable or increasing populations during the 1970s (31). Laws controlling hunting and capture exist in all countries but enforcement of protective legislation is almost non-existent (50). The species is included in both Appendix 1 of the Convention on International Trade in Endangered Species of Wild Fauna and Flora, and in Class A of the African Convention on the Conservation of Nature and Natural Resources. Conservation areas containing Gorillas exist in all relevant countries except the Central African Republic and Angola, but most are so poorly protected that they cannot be considered sanctuaries for the species. Only an estimated 3000 Gorillas live in parks and reserves: about $2000 \mathrm{G}$. g. gorilla, 750-1000 G. g. graueri, and 400 G. g. beringei.

The species has been the subject of numerous studies, many of which have been directly concerned with its conservation $(24,31,35,37,47,48,49,53,54,72,93,94)$. The Mountain Gorilla has 
been the focus of an extensive conservation programme in Rwanda $(47,51,52,53,94)$ and recently in Zaire $(4,58,89)$. Conservation needs for the Gorilla include the implementation of protection laws, and ideally laws prohibiting, not simply controlling, the capture and sale of Gorillas need to be passed in all countries; the adequate protection of conservation areas and the gazetting of additional areas; and the development of tourism and conservation education programmes. Surveys in Congo (Brazzaville) and Rio Muni would also be desirable.

STATUS BY NATION Detailed information on conservation status of Gorillas in the countries within its range are presented below separately for the different subspecies.

\section{WESTERN LOWLAND GORILLA}

VULNERABLE

\section{Gorilla gorilla gorilla Savage and Wyman, 1847}

\section{Gabon}

DISTRIBUTION About $85 \%$ of Gabon's 267667 sq.km is still covered by forest (9) and Gorillas are widespread through most of the country, being absent only in the south-east and in areas of savanna $(85,86,87)$.

POPULATION A nationwide census undertaken between December 1980 and February 1983 estimated Gorilla numbers to be $35000 \pm 7000(85,86)$. The figure for Gorillas is much larger than previous estimates (e.g. 1980 estimate of $5000-7500$ (31)). This is because i) Gorillas occur in almost all types of forest and are at higher densities in primary forest than had been previously thought; and ii) the geographical distribution of Gorillas in Gabon is wider than previously believed $(85,87)$. Gabon has one of the lowest human population densities in the world (about 3 people per sq.km) and extensive areas of the country are almost uninhabited. Gorillas occur at low population density $(0.2$ per sq. $\mathrm{km})$ in primary forest which is the predominant vegetation type, but population density increases in areas where seccndary forest is also available $(86,87)$.

THREATS Because of the low human population and the huge areas of forest still remaining, Gorillas can still be considered as safe in Gabon in the 1980 s $(85,86,87)$. The most serious threat to ape populations in the country is local hunting for meat $(85,86,87)$. Although the human population density is low, the rural population depends heavily on forest animals as a source of protein since there is no tradition of raising domestic livestock. The level of hunting pressure varies, being heaviest in the north where Gorilla flesh is considered a delicacy and lightest in the south-west where the major ethnic group has a taboo against killing or eating apes $(55,85,86,87)$. Selective logging is a lesser threat. The density of commercially valuable trees is low, and although the habitat is changed, it appears that Gorilla densities return to normal levels 3-6 years after logging $(85,86,87)$.

CONSERVATION MEASURES The Gorilla is temporarily protected by a law dating from February 1981, which suspends "big-game" hunting in Gabon (87). These laws however are not enforced in rural areas $(85,87)$. No national parks have yet been established in the country but there are several large reserves. The Gorilla is known to occur in the Lopé-Okanda Reserve (5000 sq.km) in central Gabon, in the Moukalaba Reserve (1000 sq.km) in the south-west (87), and in the Wonga-Wongue Reserve in the west $(17,29,85,86,87)$. Within the Lope-Okanda Reserve Gorillas are subject to hunting (29). However the Ministry of Eaux et Forêts has recently (1982) built a camp on the central access route and is controlling entry into the reserve in an attempt to reduce poaching from the villages on the northern limit. A 1982 report has suggested moving this northern boundary $5 \mathrm{~km}$ south of the main Libreville-Booue railway, in order to create a reserve that can be adequately protected. Both the Lope-Okanda and the Moukalaba have been selectively logged, the latter extensively, and the threat of future forestry activity is very real unless these two areas are granted national park status (87). A census project funded by the Centre International de Recherches Medicale de Franceville (CIRMF) began in December 1980 and was completed in February $1983(86,87)$. It is planned to use the results to identify areas of high Gorilla density with no major conflicting human interests and to encourage the establishment of new protected areas $(6,87)$. In particular, Tutin and Fernandez have 
recommended that the Lopé-Okanda Reserve should be made the first national park in Gabon, and that more reserves should be established in the north and north-east of the country (85). Since Gabon contains more than half of the total West African Gorilla population it is strongly recommended that these conservation areas be established for the Gorilla and the tropical forest ecosystem (86).

\section{Rio Muni (Equatorial Guinea)}

DISTRIBUTION There are four main centres of Gorilla distribution in the country: i) a $60 \times 25 \mathrm{~km}$ area in the extreme north-west (Campo-Mbia) north of the capital, Bata, and contiguous with the Campo Reserve area of Cameroon; ii) a $20 \times 50 \mathrm{~km}$ area in the extreme south-east (Mokula); iii) a $60 \times 30 \mathrm{~km}$ area (Mobumuom-Mitra) at the base of the region encompassed by the northward curve of the River Benito; and iv) a $35 \times 30 \mathrm{~km}$ area (Nkin) just north-east of the northward curve of the River Benito. Gorillas also occur in a number of smaller areas scattered throughout the rest of the country $(65,78,79)$. For map see $(79)$.

POPULATION The estimated total was 1000 in 1980, possibly as high as 2000 (50). Jones and Sabater Pi (1971) stated that they believed "a few hundred Gorilla" remained in the country in the late 1960s (65). Measurement of the area occupied by the four principal populations (79), and assumption of a density of 0.5 Gorillas per sq.km (65) gives a figure of 925 animals. Given the occurrence of Gorillas outside these main areas (79), the population could well be in excess of 1500 animals (50).

THREATS Sabater Pi reported that the normal threats of hunting and habitat loss existed up until 1968. With Independence and the confiscations of firearms, combined with the abandonment of commercial logging schemes, the concentration of the populace in the coastal regions where Gorillas do not occur, and large scale emigrations, these threats were reduced $(78,79,80)$. However Gartlan mentions that one of the main methods of Gorilla hunting in the country is trapping with wire nooses and he suspects that such trapping did continue after Independence (31). Forest exploitation and the human population will almost certainly increase $(65,78,79)$ as a result of a return to economic and political stability, which could be detrimental to the Gorilla population in the absence of management programmes.

CONSERVATION MEASURES The capture and sale of Gorillas is prohibited by law but is not enforced (65). Gorillas occur in the 10000 ha Monte del Frio National Park established in the extreme south-east in prime Gorilla habitat, and in the 26000 ha Monte Raices Wildlife Reserve although the population there is reported to be unstable $(78,79)$. Research by Sabater Pi $(65,78)$ has suggested the following priorities. National parks of at least 50000 ha need establishing in all the four main centres of Gorilla distribution $(78,79)$. Protection in the Campo-Mbia area in the north-west would be particularly valuable since it is adjacent to Cameroon's Campo Reserve and would thus provide a large contiguous protected area. However it is also closer to the capital city and therefore more difficult to protect against encroachment in the long-term unless it can be developed as a major tourist attraction. The extreme south-east is furthest from the coast and the capital and thus possibly safest for establishing a major protected area. The 10000 ha National Park of Monte del Frio would provide vital protection if considerably enlarged: 50000 ha would cover most of the area of dense Gorilla population in the region $(78,79)$.

\section{Congo (Brazzaville)}

DISTRIBUTION Gorillas occur in three disjunct areas. i) In the extreme north-west in a $280 \times 100 \mathrm{~km}$ rectangle between Gabon and Cameroon. ii) In the extreme south-west from approximately $20 \mathrm{~km}$ inland from the coast to the main Dolisie-Lambarené road; Gorillas used to be abundant in those areas where no logging had occurred (31). And iii) Gartlan in 1980 also mentioned Gorillas occurring in west central Congo near the headwaters of the Ogooue River around Zanaga (31). They may also occur between Ouesso and Impfondo in the central north where there have been reports of sightings, but since much of the area is apparently swamp, this seems unlikely $(15,31)$.

POPULATION In 1980 the total was believed to be probably not less than 1000 and could possibly be 2000-3000 (50), comprised of about 500 in the south-west (31), and more than 500 in the north-west where vegetation is known to be forest with apparently low human density and minimal road development (50).

THREATS Protected areas (whether in Gorilla habitat or not) comprise only $2.5 \%$ of the land surface and only one, Odzala National Park (which happens to contain Gorillas) is of sufficient 
legal status to prevent exploitation. In 1979 the Ministry des Eaux et Forêts (which manages all conservation areas) received no funds other than for salaries; no significant increase in protection can be expected therefore, without considerable international support (83).

CONSERVATION MEASURES The 126000 ha Parc National d'Odzala (which is also a UNESCO Man and the Biosphere Reserve) and the contiguous 68000 ha Lekoli-Pandaka Reserve in the north-west contain Gorillas $(83,91)$. They are also said to occur in the 30000 ha Tsoulou hunting area though vegetation is reported as grass and "forest remnants" (83). The Government has expressed an interest in augmenting protection afforded to existing areas with a view to increasing tourism. In particular, a $27700-87700$ ha national park and 127000 ha reserve (Conkouati conservation area), extending from the coast to the Kouboula Mountains in the south-west adjacent to Gabon, has been declared. Although the area is not primarily intended to protect the Gorilla, it is still densely forested and does contain the species $(83,91)$.

\section{Cameroon}

DISTRIBUTION Essentially Gorillas are found in four separate areas: i) the south-west, ii) the south-east, iii) the central south, and iv) the north-west (31). Main concentrations are those in the far south-west, including Campo Reserve, and the south-east (31). Gorillas are sparse in the central south where only relict populations now survive, their range having decreased by two-thirds in the last century (31); three surveys of the Dja Reserve in the late 1970s found only traces of Gorillas in one corner $(31,93)$. In the extreme north-west a relict population was reported to survive in 1977 in the Takamanda Reserve by the Cross River on the border with Nigeria (93) and recent surveys confirm the presence of Gorillas in the area (26). The species may also survive in the Pangar Djerem region in central east Cameroon where Gorillas were definitely present in the early 1970 s $(8,15,31)$.

POPULATION Gartlan, who has conducted extensive primate field studies in the country, reported in 1980 an estimated total of about 1500, comprising 500 in the south-west where there is a viable population (being relatively abundant in the Campo Reserve), less than 1000 in the south-east and central south, 200 in the north-west, and possibly a few in the central east (31).

THREATS Of populations in the four geographic areas, those in the south-west are probably the least threatened. These populations have however been affected by increasing human numbers and their associated pressures, and by development and logging projects, all of which can be expected to continue. The Campo Reserve, the main refuge for Gorillas, is facing problems. A French logging company, La Forestière de Campo, holds a 25 -year logging permit for the reserve (31); it has been logging since 1968 (10). Of greater threat for the future may be a Government Project (Societé Africaine Forestière et Agricole du Cameroun) whose aim is the development of perennial plantation crops. It has identified the extreme south-west, including the Campo Reserve, as agronomically the most interesting and therefore of developmental potential. Similarly, two oil companies, Elf and Gabon, are prospecting throughout the coastal region of Cameroon, including the south-west. If oil is found then the entire region can be expected to be greatly affected (31). In addition, Kribi, a port about $100 \mathrm{~km}$ north of Campo, is undergoing increasing development, and finds of natural gas deposits of considerable size make further development even more likely. A significant increase in the size of the city might increase the hunting pressure on adjacent rural areas including the Campo Reserve (10). Certainly a need to increase the availability of sources of protein for Kribi will become necessary (10). In the other main Gorilla population centre in the south-east, Gartlan in 1980 reported extensive logging operations to be in progress (31). In the central south the species disappeared as Yaoundé, the capital city, grew. Obala, where Gorillas were collected in colonial times, is now a suburb of Yaoundé and much of the surrounding area is extensively farmed (31). The few individuals left in the north-west are reported by Webb to be intensively hunted $(31,93)$. If the Pangar-Djerem population still survives in the central east of the country, it lives in the vicinity of the new railroad from Yaoundé to N'Goundéré and may be adversely affected by it (31).

CONSERVATION MEASURES The species is totally protected against hunting (10). Several reserves contain Gorillas: Campo (about $250000 \mathrm{ha}$ ) in the south-west is believed to contain about 200-300 (10); the Dja Reserve (about $400000 \mathrm{ha}$ ) in the central south (proposed as a National Park $(32,33)$ ), and the Takamanda Reserve (about $50000 \mathrm{ha}$ ) in the north-west. Surveys of the latter two areas by Julie Webb in the late 1970 s indicated that Gorillas were only found on the extreme edges of both reserves (southern boundary of Takamanda and eastern boundary of Dja) $(31,93)$. A new national park established in the central east (Pangar Djerem, about 450000 ha) may or may not contain Gorillas $(10,31)$. The proposed Gorilla Sanctuary at 
Lac Lobéké in the south-east is largely swamp forest and is unlikely to contain the species (31). Several workers have focused on Gorilla conservation problems in Cameroon $(8,10,30,31)$. The main requirements are the establishment of reserves or national parks in the south-east where none exist at present, and surveys of the Takamanda and Pangar-D jerem (central east) areas.

\section{Central African Republic}

DISTRIBUTION Gorillas occur in the extreme south-west of the country; the northern limit being possibly a line running east-west through $\mathrm{Ngama}\left(3^{\circ} 40^{\prime} \mathrm{N}\right)$, east to about $17^{\circ} 30^{\prime} \mathrm{E}$, where their range is probably cut off by a savanna strip extending down to Mandoukou. They are almost certainly extinct in the Mongoumba-Mbaika region (82).

POPULATION No nationwide survey has been made. In 1980, Spinage estimated that fewer than 500 Gorillas were present (82). A 1986 survey of the Dzanga-Sangha region in the south-west suggested that within a 700 sq.km block of forest densities ranged from $.89-1.45$ animals per sq.km (11).

THREATS About half the forested areas of the south-west are exploited for forestry $(11,82)$. Some hunting for meat is also a threat (11). A 3000 sq.km area of forest in the region has been designated as a forest reserve, but this reserve has not yet been gazetted and remains without formal protection (11).

CONSERVATION MEASURES Gorillas are protected by law (82). The relatively high densities in the Dzanga-Sangha region suggest that efforts to establish a protected area would contribute towards the protection of viable populations of Gorillas. Additional information on the threats facing Gorillas in this area are needed in order to determine adequate conservation measures.

\section{Nigeria}

DISTRIBUTION A survey in December 1987-January 1988 established the presence of Gorillas in pockets of forest along the southern border with Cameroon (59). Their distribution appeared to be limited to patches of montane vegetation, and they were absent from forest north of Korup National Park in Cameroon. Gorillas had been thought to have become extinct in Nigeria so the recent find is of importance. Gorillas survived in the rain forest zone of the south-east on the border with Cameroon, just north of the Cross River until at least the mid-1950s $(2,25,42,70,76)$. They have been found in four separate areas between 500-1000 $\mathrm{m}$ in elevation within the Afi River Forest Reserve and the Boshi-Okwangwo Forest Reserve, with a tiny population in forest patches on the Obudu Cattle Ranch (59).

POPULATION The area of historical distribution was very small, and it is unlikely that populations ever totalled more than a few hundred $(31,70)$. Those forest patches now containing Gorillas are extremely limited in size; between $0.5-1 \mathrm{sq} . \mathrm{km}$ (59). The populations in the Afi River and Boshi-Okwongwo Forest Reserves are very tentatively estimated by Harcourt et al. (1988) as between 50-250 animals, with as much as 50\% error (59). They have suggested that about 150 animals are likely to remain in the region.

THREATS Hunting has long been identified as a major threat (70). Currently, forest clearance for agriculture, such as on the Obudu Cattle Ranch, has restricted areas of Gorilla habitat to the slopes of mountains that are too steep to cultivate. Hunting is intense and has pushed Gorillas beyond the extension of agriculture; they are now found only in the most inaccessible areas of their range (59). Harcourt et al. estimated that about 15 Gorillas were killed each year in the region, while replacement through births was probably around 10 babies per year. If hunting is uncontrolled Gorillas could become extinct in the country with 15-20 years, even without further agricultural expansion (59). Hunting is primarily for cash sales in distant markets, rather than for local consumption.

CONSERVATION MEASURES Gorillas are protected by law in Nigeria (59). The control of hunting is one of the primary conservation efforts in the region. Three specific recommendations for the area have been made (59): i) Negotiate the cessation of hunting with the villagers in the area, primarily by replacing the lost revenue with alternative sources. This would involve a complete ban on the hunting of Gorillas, the establishment of core areas within the reserves where no hunting or forestry could take place, which could be graded with controls on the species that could be hunted in limited areas. ii) To attempt to develop the tourist potential of the area as a means of providing revenue to local residents when hunting is limited; this may be most possible on the Obudu Cattle Ranch, which already exists as an established 
tourist attraction. iii) To develop conservation education programmes through bodies such as the Nigerian Conservation Foundation. Such programmes have been demonstrated to have a major impact on creating positive attitudes both to the wildlife and to the necessity for controlling utilization of forest resources. While it would theoretically be possible to enlarge the reserves to incorporate all the now fragmented populations, this would have to be structured around existing villages and might lead to conflicts between the local residents and the central government, the effects of which would be felt primarily by the Gorillas.

\section{Angola}

DISTRIBUTION Reports were received in March 1982 confirming the continued presence of Gorillas in the Cabinda enclave which lies north of the Zaire River (73).

POPULATION Current status is unknown.

THREATS Some habitat alteration has taken place within their range but quite how much this has affected the population is not known (73). In 1976 it was reported that hostilities had probably not seriously affected Gorillas (62).

CONSERVATION MEASURES In the early 1970s plans were in progress for the establishment of a Gorilla sanctuary in Cabinda (61); however by 1984 no protected area had been established (3). Renewed efforts would be worthwhile.

EASTERN LOWLAND GORILLA

Gorilla gorilla graueri Matschie, 1914

MOUNTAIN GORILLA

Gorilla gorilla berengei Matschie, 1923
ENDANGERED

ENDANGERED

\section{Zaire}

DISTRIBUTION Until at least the 1960s Zaire harboured populations of both Western and Eastern Gorillas. However, Verschuren reported that the Western Gorilla, G. g. gorilla, inhabiting the Mayumbe District was almost certainly extinct by 1975 , although individuals possibly occasionally entered from the Cabinda enclave of Angola and from Congo (Brazzaville) (90). Little is known of the Eastern population. Emlen and Schaller conducted a five-month survey of the region in the late 1950 s (14). They reported about 60 population centres within a 91000 sq.km inverted triangle, its base on the equator extending east from north of Lubutu (about $26^{\circ} 30^{\prime} \mathrm{E}$ ) to Mt Tshiaberimu (near Lubero at the northern end of the Virunga National Park, just west of Lake Edward at about $29^{\circ} 15^{\prime} \mathrm{E}$ ) and its apex just west of Fizi west of the northern shore of Lake Tanganyika (about $4^{\circ} 20^{\prime} S$ ) (24). It is possible that the species range extends further north to the equator and, in the region of the equator, west to the Lualaba River. Emlen and Schaller estimated the area occupied by substantial populations within the 91000 sq.km limits as about 5000 sq.km. (24), while Schaller (81) estimated the total area occupied as 21000 sq.km. In view of Tutin and Fernandez' findings of Gorillas in primary forest, it is difficult now to identify the western limits to the population. Eastwards, however, the area occupied has undoubtedly diminished, because of the consistent spread of agriculture (37). There may have been some local range expansions in the north and north-east where mixed forest has replaced pure primary forest (36). A population existed in the Djabbir region, near Bondo, north of the Uele River as late as $1908(1,14,81)$; this is halfway between the present eastern and western populations of the species and it would be extremely useful to confirm if any Gorillas still survive in the region.

POPULATION The Western population (G. g. gorilla) is almost certainly extinct. The Eastern subspecies was estimated to number 3000-5000 within the known range in 1980 . If the population extends further west than currently established, the population estimates will have to be revised. Three different estimates exist at present: i) Assuming the total range has been 
effectively reduced to the population centres described by Emlen and Schaller in 1960 (i.e. about 5000 sq.km (24)) and assuming a density of 0.6 Gorillas per sq.km (known to be reasonable for population centres (56)) this gives a population of 3000 animals. ii) Assuming a mean density of 0.25 animals per sq.km in an original $21000 \mathrm{sq} . \mathrm{km}$ total range (81), gives just over 5000 animals (37). iii) However, it is highly unlikely that the same area of habitat is available now as in the late $1950 \mathrm{~s}$. Thus, assuming a $25 \%$ reduction to $15000 \mathrm{sq} . \mathrm{km}$ gives a total population of about 4000 animals at 0.25 per sq.km. For the late 1950 s Emlen and Schaller estimated a total population of 3000-15 000 (24), and Schaller (1963) 5000-15 000 (81). Although the present figures overlap these, it seems highly unlikely that the population has in fact remained stable. The decline in the Virunga Volcano population (the Mountain Gorilla, G. g. beringei) matches what has probably occurred over most of Africa. In the late 1950s, 400-500 Gorillas lived in the Virungas (81); by 1973 , the population was down to 275 (54), and by 1981 to 250 (58) with most of the decrease occurring in the Zaire section (58).

THREATS The main threat to Gorillas is forest clearance, e.g. a $450 \mathrm{sq} . \mathrm{km}$ area of mixed forest around Mt Tshiaberimu, which contained an important concentration of Gorillas, had by 1980 decreased to less than 250 sq.km, cattle ranches and cultivation replacing the other $200 \mathrm{sq} . \mathrm{km}$ (37). Goodall concluded from his $1979-80$ survey that Gorillas could become extinct in the area within a few years unless positive action was taken (37). Most of the reduction in the Virunga Gorilla population $G$. g. beringei has occurred in the Zaire section and yet, in contrast to Rwanda, no land has been officially appropriated from the reserve area. A possible reason for the decline may be that the presence of livestock in the Zaire Virungas has been of major detriment to the Gorilla population (50). Disturbance within conservation areas, resulting from the illegal use of the resources (wood and water collectors, smugglers, and poachers) is detrimental to Gorillas $(4,9)$. Gorillas, especially juveniles, are highly at risk from wire snares set to capture small game (4). While Gorillas are not hunted for food nor as crop pests in the Virungas, a peculiar threat has acted on that population. As well as being killed in order that infants can be captured for sale, adults, especially males, have since 1976 been killed so that their skulls can be sold as souvenirs to tourists and expatriate residents $(52,53,94)$.

CONSERVATION MEASURES Laws prohibit the hunting of Gorillas in Zaire. The species occurs in three major national parks. i) Maiko N.P. (1 $000000 \mathrm{ha})$ in the centre of the northernmost part of the range, although the Gorilla population in the region is sparse. ii) Kahuzi-Biega National Park established in 1970 (600 000 ha) just west of the south half of Lake Kivu ( $\left.2^{\circ} \mathrm{I}{ }^{\prime} \mathrm{S}, 2^{\circ} 45^{\prime} \mathrm{E}\right)(37,72)$. Murnyak, who conducted the first detailed Gorilla census in the park from March 1978 to February 1979, arrived at a total of about 240 Gorillas and on available evidence believed that the park supported a relatively stable and perhaps increasing Gorilla population (72). In the mid-1970s the park was extended to 600000 ha mainly into primary forest $(37,72)$. A programme of tourism based on the Gorilla presence in the park was developed during the early 1970s and continues. iii) Virunga National Park (est. 1925), north-east of Lake Kivu, which covers about 23000 ha and harbours a population of about 130 Gorillas (58), and Mt Tshiaberimu west of Lake Edward where the protected area is tiny (25000 ha) and now contains mainly bamboo forest, a vegetation zone used by Gorillas only seasonally in other areas (12,13,37). Between September 1979 and March 1980 Goodall undertook a pilot survey for conservation management of Eastern Gorillas in Zaire (IUCN/WWF Project 173l) (37). The project aimed to update the information of Emlen and Shaller's 1959 survey and to lay the foundation for future Gorilla conservation in the country (37). Goodall's recommendations included the establishment of an headquarters for Gorilla conservation management in Zaire (as a first stage towards a national conservation strategy being formulated for all of the country's natural resources) and surveys of the Mt Tshiaberimu and Kabara areas. In March 1984, "the Eastern Zaire Gorilla Conservation Project" was launched. The ongoing project aims to determine the distribution and status of the various populations of Gorillas in the Kivu Province of eastern Zaire, identify threats to their existence, recommend actions and policies which might alleviate these problems, and begin work on activities which are determined to be most urgent in conserving the most important populations. The project includes most of the existing G. g. graueri population and part of the Virunga population of $G . g$. beringei. Given adequate protection from poaching and disturbance, the Zaire populations have the potential for increasing, at least in the Virunga area $(4,89)$. 


\section{Uganda}

DISTRIBUTION Gorillas effectively exist only in 235 sq.km of the 310 sq.km Bwindi Forest Reserve (Impenetrable Forest Reserve) in south-west Uganda on the Zaire border, $30 \mathrm{~km}$ north of Kisoro (49). Stragglers also enter the $25 \mathrm{sq.km}$ Gorilla Game Sanctuary (Uganda's section of the Virunga Volcano conservation area) from the adjacent Rwandan section but the area is used so extensively by the local people that the Gorillas remain only a few days at most (48).

POPULATION A 1981 total of 95-135. A survey of the Bwindi Forest Reserve in early 1979 indicated a Gorilla population of 95-135 animals (49) i.e. about one-third of the world's Mountain Gorilla population. This overlaps Schaller's estimate in the late 1950s of 120-180 (81). However, along with Itani's estimate for the late 1950s of 150 (64), the results indicate a slight decline. There are effectively no Gorillas in the Gorilla Game Sanctuary in the Virungas (58).

THREATS Harcourt reported in 1979 (47) that the Bwindi Forest Reserve population was probably one of the better protected in Africa. He noted that the Forest Department allowed only manual extraction of timber and thus logging was highly selective. However, logging was effectively allowed over the whole reserve and some hunting of Gorillas did occur. In 1984, it was noted that illegal lumbering had increased considerably since Harcourt's survey (92). Furthermore a forest reserve, in contrast to a national park, can be degazetted at almost a moments notice and the land sold. Since the Uganda Forest Department had (as of 1982) neither the money nor the vehicles to protect the Bwindi Reserve properly, such an eventuality might not be unlikely $(48,49)$. The Gorilla Game Sanctuary, is a sanctuary in name only: extensive incursions by the local people and their livestock result in its acting merely as a buffer zone to the adjacent Rwandan Parc National des Volcans.

CONSERVATION MEASURES Gorillas occur in the 31000 ha Bwindi Forest Reserve (49). The Forest Reserve contains two nature reserves in which all forms of exploitation are forbidden and which were gazetted "to provide the Gorilla ... with a sanctuary" (67). The smaller of these (200 ha) is not in Gorilla habitat; the other $(800 \mathrm{ha})$ is not large enough to support even one Gorilla group, let alone a viable proportion of the population (49). Harcourt who conducted the 1981 survey made recommendations for increased protection of the reserve (49). The most important is to restrict logging to $15 \%$ of the reserve (a step that according to Harcourt can easily be accomplished within the present framework of management). In 1980 logging was allowed over $97.5 \%$, the recommended restriction would ensure 23000 ha of forest as a Gorilla sanctuary (49). A project entitled "Conservation of the Bwindi Forest, south-west of Uganda, with particular reference to the Mountain Gorilla" is underway $(89,92)$. Its aims are to implement practices to ensure the survival of the Bwindi Forest Gorillas; to provide a foundation for the long-term monitoring of the Bwindi's natural resources; to develop and effective management and conservation policy for the Bwindi Forest that can be incorporated into the Uganda National Conservation Strategy; and to promote an improvement in the protected area status of the forest should this be necessary (92). A few Gorillas occasionally use the 2500 ha Gorilla Game Sanctuary. However, the sanctuary is heavily settled and provides virtually no protection to the Gorillas $(48,69)$. Malpas and Infield visited the area in November 1981 and made recommendations for improved protection (69). If Gorillas are to survive in the area it is imperative that it be turned into a national park as soon as possible; in 1980 it afforded no sanctuary at all; in fact, the extent of encroachment into it threatened the adjacent Rwandan Parc National des Volcans (81).

\section{Rwanda}

DISTRIBUTION Found only in the extreme north-west in the 120 sq.km Parc National des Volcans (approx. $1^{\circ} 30^{\prime} \mathrm{S}, 30^{\circ} \mathrm{E}$.), Rwanda's section of the Virunga Volcano conservation area $(24,52,53,54,58,81)$.

POPULATION Recent censuses suggest that the population totals about 120 animals (58) and currently is stable or slightly increasing (89). About 150 Gorillas probably used the Rwandan section of the Virungas in the late 1950 s (81). In 1968, the area of Gorilla habitat in the country had almost halved, yet in 1973 about 110 animals used the Rwandan section much of the time and another 30-40 some of the time (Harcourt, A.H. unpubl.); in early 1981 the figures remained the same $(58,95)$.

THREATS All threats mentioned for the Zairian section above also face the Rwandan Gorilla population (19,52,53,94). By 1982, because of the work of the Mountain Gorilla Project (47), all were under control. However, Rwanda's human population is increasing rapidly (more than $3 \%$ 
per year) in what is already the most densely populated country in Africa $(53,94)$. Thus no natural habitat, even that in national parks, can be considered as safe. For example, up until early 1980, the Rwandan Ministry of Agriculture was considering removing up to $50 \mathrm{sq} . \mathrm{km}$ from the Parc National des Volcans for a cattle ranching scheme; having already removed, in collaboration with the Fonds Europeen de Development (F.E.D.), 100 sq.km in 1968 (19).

CONSERVATION MEASURES Gorillas occur, and are confined to, the 12000 ha Parc National des Volcans. In 1978 a major campaign was launched (initially entitled "Gorilla Habitat Preservation in Rwanda", in 1979 evolving into "The Mountain Gorilla Project"). By late 1979, a Tourism Development and Conservation Education programme was underway and in early 1980 the park guard force was fully supplied with uniforms and equipment, and a training programme had been started $(47,51,52,53,94)$. By late 1981, the Tourism Development Programme had been so successful that for the first time in its history the park was paying for itself (50). In addition to the programmes already in progress, a building programme of park offices and housing for the park guards has been funded by the Coopération Belge in Rwanda (50). Studies of the Mountain Gorilla have been ongoing for many years in particular from the Karisoke Research Centre $(4,27,28,45,46,51,54,95)$. Much that is needed for conservation has been initiated but the continuation of the programmes needs to be guaranteed $(47,50,89)$. Gorillas are fully protected by law in Rwanda.

HABITAT AND ECOLOGY Favoured Gorilla habitats are forest edges, regenerating (secondary) forest e.g. abandoned field and logging concessions, montane forest, riverine forest and, in certain seasons, bamboo forest $(12,13,34,37,72,79,81,86,87)$. The species will also occur in primary forest at low density $(86,87)$. Altitudinal range is from sea level up to (in the Virungas) $3400 \mathrm{~m}$, with very occasional forays even higher $(8,10,12,27,28,34,35,37,65,77,81,86,87)$. In East Africa the Gorilla is primarily a folivore, the diet being largely composed of herbs, shrubs and vines which occur where the forest canopy is broken (e.g. along rivers and roads). However, as for many other primates, fruits are far more important in the diet in Equatorial West Africa $(56,88)$, although observations in Cameroon (10) and Gabon (88) indicate that Gorillas continue to eat stem, pith, and small quantities of leaves along with fruits. Gorilla densities approach 1 per sq.km in favoured habitat, and biomass about $0.65 \mathrm{~kg}$ per ha. Using the standard definition of a territory as an actively defended area of land, Gorillas do not hold territories; yearly ranges overlap extensively, and the frequency and intensity of aggression between different groups, or between groups and lone males, bears no relation to site. Mutual avoidance does, however, result in areas of almost exclusive use within a group's range. The size of the yearly range varies from about $5 \mathrm{sq.km}$ in prime habitat for a group of about ten animals up to about $35 \mathrm{sq} . \mathrm{km}$; there is some evidence that range size is proportional to group size $(12,27,28,34,65,81)$. Seasonal patterns of range use have been shown in the Kahuzi region (47). The length of a group's day journey is normally between 0.5 and one $\mathrm{km}$.

In both West and East Africa the majority of Gorillas live in fairly stable bisexual groups that normally consist of a single fully adult male, 2-4 adult females and 2-5 immature animals (less than eight years of age) (56). Lone males (less than $9 \%$ of most populations) are the only individuals living outside such groups $(24,81)$. The median group size in West Africa of five animals (range 2-10) is significantly smaller than that in East Africa (nine animals, range 2-37) (56). The Gorilla is an unusual group-living primate in that instead of males leaving the natal group at adolescence, both sexes tend to do so. Thus adult females in a group were probably not born in it and bonds between the leading male and the females, not between adult females, maintain group cohesion. Emigrant females usually transfer to lone males and very small groups; males, however, travel alone until they can attract females and form a group of their own. Occasionally a son will stay to inherit leadership of a group $(43,44,45,46,48)$.

Females first breed in the wild at about ten years of age, males not before about 15 years, although in captivity both sexes are known to be fertile at about eight years. A single young is born after a gestation period of 8.5 months. Depending on conditions, the birth interval between surviving offspring varies between 4-8 years. Immature mortality averages about $40 \%, 60 \%$ of it in the first year of life. Longevity in the wild is not known, but the current guess is about 35 years $(55,56,57)$. 
CAPTIVE BREEDING 207 males and 263 females were recorded in 118 zoological collections at the end of 1981 (74). The International Studbook of the Gorilla published in 1979 (66) and covering the 15 years between 1 January 1962 and 31 December 1976 recorded that during that time a total of 658 Gorillas had been held in captivity ( 300 males, 356 females and two of undetermined sex in 139 collections). Of these 515 had been wild caught and 143 captive bred. By the end of 1976 deaths (160) had outnumbered births (143) and in particular 3.6 times as many animals had been taken from the wild as had been born in captivity; zoos and other such institutions can thus be said to have consumed more Gorillas than they had produced. However, the situation is improving: the ratio of wild caught to captive born animals changed between the periods 1 January 1962 - 30 June 1970 and 1 July 1970 - 31 December 1976 from 10.74:1 $(\mathrm{n}=411)$ to $1.33: 1(\mathrm{n}=247)$. The data from Great Britain and Ireland indicate that the trend can be expected to continue. Thus the ratio of wild to captive-born in November 1976 was $3.46: 1$ $(n=58)$ while on 31 December 1979 it was $1.86: 1(n=63)(68)$. Between 1 July 1970 and 31 December 1976, only three countries produced more Gorillas in captivity than they took from the wild. These were the U.S.A. $(+55)$, Spain $(+4)$ and Switzerland $(+5)$. All others contributed to Gorilla losses in the wild, with the worst offenders being West Germany $(-12)$, Holland $(-11)$, Japan, Czechoslovakia, Denmark and Poland (-9 each), Canada (-8), E. Germany (-7), U.S.S.R., South Africa and France ( -6 each), and Australia (-5). The figure for the U.S.A. becomes less impressive when deaths are taken into account. Then the sum increase contributed to the Gorilla population is +5 , but given that the 11 captured in that time probably resulted in at least as many more being killed in the process, it too must be counted as a consumer. Thus only Switzerland, who took none from the wild in that period, contributed to the conservation of the species.

REMARKS For description of animal see $(22,23,38,41,81)$. It is worth noting that the taxonomic position of the Gorillas in the Bwindi Forest Reserve of south-west Uganda (Uganda's only viable Gorilla population) is unclear $(40,41)$. Given the reserve's close proximity to the Virungas and the fact that forest joined the two regions comparatively recently, it seems reasonable to classify this population as beringei, especially as there is no trace of recent forest between Bwindi and the nearest known graueri population $(5,41)$. Bwindi and Tshiamberimu Gorillas were suggested by Groves (41) for inclusion in graueri. There is a tendency to place Gorillas in Pan rather than keeping them in the separate genus Gorilla.

The research and initial draft of this data sheet was very kindly undertaken for the Conservation Monitoring Centre by Dr Alexander $\mathrm{H}$. Harcourt. The following responded most helpfully to requests for information: Dr A. Brosset, Dr J. Calvert, Dr A.G. Goodall, Dr R. Kirchshofer, Mr J.J.C. Mallinson, Mr D.E. Murnyak, Dr J. Sabater Pi, Dr C.A. Spinage, Dr A. Vedder and especially Dr J.S. Gartlan .

\section{REFERENCES}

1. Allen, G.M. (1939). A Checklist of African Mammals. Bulletin of the Museum of Comparative Zoology, Harvard 83: 1-763.

2. Allen, J.G.C. (1931). Gorilla hunting in southern Nigeria. Nigerian Field 1: 4-9.

3. Anon. (1982). Os Parques Nacionais e as outras zonas de proteç̧ao da Natureza de Angola. Direcçao Nacional da Conservaçao da Natureza, Luanda, Angola.

4. Aveling, C. and Harcourt, A.H. (1984). A census of the Virunga Gorillas. Oryx 18(1): 8-13.

5. Awunti, J.C. (1978). In: Chivers, D.J. and Lane-Petter, W. (Eds), (1978). Recent Advances in Primatology II Conservation. Academic Press, London. Pp. 75-79.

6. Baulieu, E. (1980). The Centre International de Récherche Medicale de Franceville (CIRMF) and the Symposium on the Great Apes of Africa. In: Short, R.V. and Weir, B.J. (Eds), The Great Apes of Africa. Proceedings of a Symposium held in Gabon, West Africa. J. Reproduction and Fertility Supplement, No. 28. 173 pp.

7. Blancou, L. (1951). Notes sur les mammifères de l'equateur africain français. Mammalia 15: 143-151.

8. Bützler, W. (1980). Présence et répartition des Gorilles, Gorilla gorilla gorilla (Savage and Wyman, 1847), au Cameroun. Säugetierkundliche Mitteilungen 28: 69-79.

9. Caballé, G. (1978). Essai sur la géographie forestière du Gabon. Adansonia 17: 425-440.

10. Calvert, J. (1980). In litt. 
11. Caroll, R.W. (1986). Status of the Lowland Gorilla and other wildlife in the Dzanga-Sangha region of southwestern Central African Republic. Primate Conservation 7: 38-41.

12. Casimir, M.J. (1975). Feeding ecology and nutrition of an eastern Gorilla group in the Mt. Kahuzi region (République du Zaire). Folia Primatologica 24: 81-136.

13. Casimir, M.J. and Butenandt, E. (1973). Migration and core area shifting in relation to some ecological factors in a Mountain Gorilla group (Gorilla gorilla beringei) in the Mt. Kahuzi region (République du Zaire). Zeitschrift für Tier psychologie 33: 514-522.

14. Coolidge, H.J. (1929). A revision of the genus Gorilla. Memoirs of the Museum of Comparative Zoology, Harvard 50: 291-381.

15. Cousins, D. (1978). Gorillas - a survey. Oryx 14: 254-258.

16. Cousins, D. (1978). Man's exploitation of the Gorilla. Biological Conservation 13: 287-297.

17. Curry-Lindahl, K. (1968). Report to the United Nations Development Programme on the conservation and management of the fauna of the national parks of Gabon. $29 \mathrm{pp}$.

18. Curry-Lindahl, K. (1968). Report to UNDP on the conservation and management of the fauna of the national parks of Gabon. $29 \mathrm{pp}$.

19. Curry-Lindahl, K. (1969). Disaster for the Gorillas. Oryx 10: 7.

20. Curry-Lindahl, K. (1979). Development assistance with responsibility: Environment and development in developing countries. Report to the Government of Sweden.

21. Curry-Lindahl, K. (1979). Is Aid for developing countries destroying their environment. Oryx 15: 133-137.

22. Dandelot, P. (1974). Part 3: Order Primates. In: Meester, J. and Setzer, H.W. (Eds), (1971-1977). The Mammals of Africa: An Identification Manual. Smithsonian Institution Press, Washington D.C..

23. Dixson, A.F. (1981). The Natural History of the Gorilla. Weidenfeld and Nicolson, London.

24. Emlen, J.T. and Schaller, G.B. (1960). Distribution and status of the Mountain Gorilla (Gorilla gorilla beringei) - 1959. Zoologica, New York 45: 41-52.

25. F.C. (1934). Notes on Gorilla. Nigerian Field 3: 92-102.

26. Fay, J.H. (1987). Unpublished report to WWF(US).

27. Fossey, D. (1974). Observation on the home range of one group of Mountain Gorilla (Gorilla gorilla beringei). Animal Behaviour 22: 568-581.

28. Fossey, D. and Harcourt, A.H. (1977). Feeding ecology of free-ranging Mountain Gorilla (Gorilla gorilla beringei). In: Clutton-Brock, T.H. (Ed.), Primate Ecology. Studies of Feeding and Ranging Behaviour in Lemurs, Monkeys and Apes. Academic Press, London.

29. Gandini, G. (1979). Nature conservation and tourism in Gabon. Unpublished report.

30. Gartlan, J.S. (1975). The African forests and problems of conservation. In: Kondo, S., Kawai, M., Ehara, A. and Kawamura, S. (Eds), Symposium of the 5th Congress of the International Primate Society. Japan Science Press, Tokyo.

31. Gartlan, J.S. (1980). Conservation status of Western Gorillas. Unpublished report.

32. Gartlan, J.S. (1982). Forest conservation in Cameroon: The current situation. IUCN/SSC Primate S pecialist Grou p Newsletter 2: 20.

33. Gartlan, J.S. and Agland, P.C. (1980). A proposal for a program of rain-forest conservation and national park development in Cameroon, West-Central Africa. World Wildlife Fund Report. 31 pp.

34. Goodall, A.G. (1977). Feeding and ranging behaviour of a Mountain Gorilla group (Gorilla gorilla beringei) in the Tshibinda-Kahuzi region. In: Clutton-Brock, T.H. (Ed.), Primate Ecology. Studies of Feeding and Ranging Behaviour in Lemurs, Monkeys and Apes. Academic Press, London.

35. Goodall, A.G. (1978). On habitat and home range in eastern Gorillas in relation to conservation. In: Chivers, D.J. and Lane-Petter, W. (Eds), Recent Advances in Primatology, 2. Academic Press, London.

36. Goodall, A.G. (1980). In litt.

37. Goodall, A.G. (1980). Pilot survey for conservation management of Eastern Gorillas in Zaire. IUCN/WWF Project 1731. Final Report.

38. Goodall, A.G. and Groves, C.P. (1977). The conservation of Eastern Gorillas. In: Prince Rainier and Bourne, G.M. (Eds), Primate Conservation. Academic Press, New York. 

39. Groves, C.P. (1970). Gorillas. Arthur Barker Ltd., London and Arco Publishing Co.,
New York.

40. Groves, C.P. (1970). Population systematics of Gorilla. Journal of Zoology 161: 287-300.

41. Groves, C.P. and Stott, K.W. Jr. (1979). Systematic relationships of Gorillas from Kahuzi, Tshiaberimu and Kayonza. Folia Primatologica 32: 161-179.

42. Happold, D.C.D. (1982). In litt.

43. Harcourt, A.H. (1978). Strategies of emigration and transfer by primates, with particular reference to Gorillas. Zeitschrift für Tierpsychologie 48: 401-420.

44. Harcourt, A.H. (1979). Contrasts between male relationships in wild Gorilla groups. Behavioral Ecology and Sociobiology 5: 39-49.

45. Harcourt, A.H. (1979). Social relationships among adult female Mountain Gorilla. Animal Behaviour 27: 251-264.

46. Harcourt, A.H. (1979). Social relationships between adult male and female Mountain Gorillas in the wild. Animal Behaviour 27: 325-342.

47. Harcourt, A.H. (1979-80). Mountain Gorilla Project: Progress reports. Oryx 15: 10-11, 114-115, 324-325.

48. Harcourt, A.H. (1980). Kigezi Gorilla Sanctuary. In: Malpas, R. (Eds), Wildlife in Uganda 1980: A survey. Report to the Minister of Tourism and Wildlife, Uganda.

49. Harcourt, A.H. (1981). Can Uganda's Gorillas survive? - A survey of the Bwindi Forest Reserve. Biological Conservation 19(4): 269-282.

50. Harcourt, A.H. (1981). Draft RDB sheet for Gorilla. Unpublished report.

51. Harcourt, A.H. (1982). Census of Virunga Gorillas 1981. WWF Monthly Report February 1982: 51-52

52. Harcourt, A.H. and Curry-Lindahl, K. (1978). The FPS Mountain Gorilla Project - a report from Rwanda. Oryx 14:316-324.

53. Harcourt, A.H. and Curry-Lindahl, K. (1979). Conservation of the Mountain Gorilla and its habitat in Rwanda. Environmental Conservation 6: 143-147.

54. Harcourt, A.H. and Fossey, D. (1981). The Virunga Gorillas: Decline of an "island" population. African Journal of Ecology 19: 83-97.

55. Harcourt, A.H. and Stewart, K.J. (1980). Gorilla-eaters of Gabon. Oryx 15(3): 248-251.

56. Harcourt, A.H., Fossey, D., and Sabater Pi, J. (1981). Demography of Gorilla gorilla. Journal of Zoology 195: 215-233.

57. Harcourt, A.H., Fossey, D., Stewart, K.J. and Watts, D.P. (1980). Reproduction in wild Gorillas and some comparisons with Chimpanzees. J. Reproduction and Fertility, Supplement 28: 59-70.

58. Harcourt, A.H., Kineman, J., Campbell, G., Yamagiwa, J., Redmond, I., Aveling, C., Condiotti, M. (1983). Conservation and the Virunga Gorilla population. African Journal of Ecology 21: 139-142.

59. Harcourt, A.H., Stewart, K. and Inaharo, I.M. (1988). Nigeria's Gorillas: A Survey and Recommendations. Unpublished report to the Nigerian Conservation Foundation.

60. Harroy, J.P. (1980). Demain la Famine ou la Conspiration du Silence. Hayez, Brussels.

61. Huntley, B. (1972). An interim report on the status of Red Data Book species in Angola. Unpublished report.

62. Huntley, B. (1976). In litt. to C. Holloway, IUCN.

63. IUCN Conservation Monitoring Centre (1985). IUCN Directory of Afrotropical Protected Areas. IUCN, Cambridge, U.K. and Gland, Switzerland.

64. Itani, J. (1961). Forest of Gorillas and Pygmies. Iwanami, Tokyo.

65. Jones, C. and Sabater Pi, J. (1971). Comparative ecology of Gorilla gorilla (Savage and Wyman) and Pan troglodytes (Blumenbach) in Rio Muni, West Africa. Bibliotheca Primatologica 13: 1-96.

66. Kirchshofer, R. (1979). International Register and Studbook of the Gorilla (Gorilla gorilla). Frankfurt Zoological Garden, Frankfurt.

67. Leggat, G.J. and Osmaston H.A. (1961). Working plan for the Impenetrable Central Forest Reserve, Kigezi District. Uganda Forest Dept., Entebbe.

68. Mallinson, J.J.C. (1980). Studbook of Gorillas held in the British Isles and Ireland, 3.

69. Malpas, R.C. and Infield, M.M. (1982). The Mgahinga Forest and Gorilla Game Reserves, Uganda. Unpublished report.

70. March, E.W. (1957). Gorillas of eastern Nigeria: Oryx 4: 30-34.

71. Merfield, F.G. and Miller, H. (1956). Gorillas were my Neighbours. London. 
72. Murnyak, D.F. (1981). Censusing the Gorillas in Kahuzi-Biega National Park. Biological Conservation 21: 163-176.

73. Nkosi Luta Kingengo (1982). In litt. to P. Portas, IUCN.

74. Olney, P.J.S. (Ed.) (1986). International Zoo Yearbook 24/25. Zoological Society of London.

75. Petrides, G.A. (1965). Advisory Report on Wildlife and National Parks in Nigeria 1962. Special Publication No. 18. American Committee for International Wild Life Protection. Bronx, New York.

76. Rosevear, D.R. (1953). Checklist and Atlas of Nigerian Mammals. The Government Printer, Lagos, Nigeria.

77 Sabater $\mathrm{Pi}$, J. (1977). Contribution to the study of alimentation of Lowland Gorillas in the natural state, in Rio Muni, Republic of Equatorial Guinea (West Africa). Primates 18: 183-204.

78. Sabater Pi, J. (1980) In litt.

79. Sabater Pi, J. (1981). Exploitation of Gorillas Gorilla gorilla gorilla Savage and Wyman 1847 in Rio Muni, Republic of Equatorial Guinea, West Africa. Biological Conservation 19(2): 131-140.

80. Sabater Pi, J. and Groves, C.P. (1972). The importance of the higher primates in the diet of the Fang of Rio Muni. Man 7: 239-243.

81. Schaller, G.B. (1963). The Mountain Gorilla: Ecology and Behavior. University of Chicago Press, Chicago.

82. Spinage, C.A. (1980). Gorillas in the Central African Republic. Unpublished report.

83. Spinage, C.A. (1980). Parks and reserves in Congo-Brazzaville. Oryx 15(3): 292-295.

84. Stott, K.W. Jr. (1981). A suitable vernacular name for an intermediate Gorilla. Mammalia 45(2): 261.

85. Tutin, C. and Fernandez, M. (1983). Recensement des Gorillas et des Chimpanzes du Gabon. Centre International de Recherches Medicales de Franceville (CIRMF) et Department of Psychology, University of Stirling, Scotland.

86. Tutin, C.E.G. and Fernandez, M. (1984). Nationwide census of Gorilla (Gorilla g. gorilla) and Chimpanzee (Pan t. troglodytes) populations in Gabon. American Journal of Primatology 6: 313-336.

87. Tutin, C.E.G. and Fernandez, M. (1983). Gorilla and Chimpanzee census in Gabon. IUCN/SSC Primate Specialist Group Newsletter 3: 22-23.

88. Tutin, C.E.G. and Fernandez, M. (1985). Foods consumed by sympatric populations of Gorilla g. gorilla and Pan t. troglodytes in Gabon: Some preliminary data. International Journal of Primatology 6: 27-43.

89. Vedder, A. (1987). Status of Gorilla gorilla, 1987. Gorilla Conservation News 1: 7-24.

90. Verschuren, J. (1975). Wildlife in Zaire. Oryx 13: 25-33; 149-163.

91. Verschuren, J. (1982). Relance de la Conservation de la Nature. Faune, Flore, Reserves Naturelles. Report produced for the Ministère des Eaux et Forêts Brazzaville, République Populaire du Congo.

92. WWF/IUCN Regional Office (1984). Project proposal - Conservation of the Impenetrable (Bwindi) Forest, south-west Uganda, with particular reference to the Mountain Gorilla.

93. Webb, J. (1977). Gorilla ecology project in Cameroun. Unpublished report.

94. Weber, A.W. (1979). Gorilla problems in Rwanda. Swara 2: 29-32.

95. Weber, A.W. and Vedder, A. (1983). Population dynamics of the Virunga Gorillas: 1959-1978. Biological Conservation 26: 341-366.

96. Wolfheim, J.H. (1983). Primates of the World: Distribution, Abundance, and Conservation. University of Washington Press, Seattle and London. 



\section{APPENDIX A \\ INVENTORY REPORT FORM}

Report to be mailed to:

SCMU, IUCN Conservation Monitoring Centre

219(c) Huntingdon Rd, Cambridge, CB3 ODL, U.K.

1. Country

2. Date

3. Reporter

Name:

Address:

4. Taxon

Scientific Name:

Common Name:

5. Distribution

Present:

Former:

If possible, please include a map. Is present range preferred or enforced habitat?

6. Population

Estimated numbers in the wild. Indicate date of estimate and describe method of estimation. Are numbers increasing, decreasing or stable?

7. Habitat and Ecology

Biome type. Elevation range. Brief notes about social structure, feeding habits and diet, reproduction (gestation, breeding season, number of young, age of sexual maturation), longevity etc.

8. Scientific interest and potential value

Use in scientific or medical research; commercial value in trade or local economy.

9. Threats to Survival

Eg. habitat destruction, over-exploitation, hybridization, natural disasters, competition for food.

10. Conservation Measures Taken

Legal measures (international conventions, national laws); is law enforced? Protected areas does it occur in national parks, reserves etc.? If so, please list. Management programmes or research programmes in progress.

11. Conservation Measures Proposed

Same as for 10 , but measures that are needed for the conservation of the taxon. 
12. Captive Breeding

Numbers in captivity. Does it breed readily in captivity? Where and when?

\section{Remarks}

Reference citations for description of animal. Comments about related taxa. If the above information concerns a subspecies then brief information should be given about the distribution and status of the species as a whole. Special acknowledgements etc.

\section{References}

Can be published papers, unpublished manuscripts, or references to correspondence (cited as In litt.). 


\section{APPENDIX B}

Primates covered by protective international legislation

This legislation restricts or bans capture, hunting or trade. (African Convention, Class A and CITES, Appendix 1).

$\begin{array}{lll}\text { African } & \text { CITES } & \text { IUCN } \\ \text { Convention } & \text { Appendix } & \text { Category } \\ \text { Class A } & 1 & \end{array}$

Macaca sylvanus

Cercocebus galeritus galeritus

Mandrillus sphinx

Mandrillus leuco phaeus

Cerco pithecus diana

Procolobus [badius] gordonorum

Procolobus [badius] kirkii

Procolobus [badius] rufomitratus

Procolobus verus

Procolobus troglodytes

Pan paniscus

Gorilla gorilla

$\begin{array}{lll}X & & V \\ X & X & E \\ & X & V \\ X & X & E \\ X & X & \text { V } \\ X & X & E \\ X & X & \text { E } \\ X & & \text { R } \\ X & X & \text { V } \\ \text { X } & \text { X } & \text { V } \\ \text { X } & \text { X } & \end{array}$

All other primates are included in Class B or Appendix 2 whereby hunting and export should be regulated or monitored.

"Endangered" primates which should be considered for inclusion in protective legislation.

Cercocebus galeritus subspecies "sanjei"

Cerco pithecus preussi

Cerco pithecus erythrogaster

Cercopithecus erythrotis

Procolobus [badius] pennanti

Colobus satanas 



\section{APPENDIX C}

\section{Policy Statement on Use of Primates for Biomedical Purposes}

The Ecosystem Conservation Group and World Health Organisation recognize that nonhuman primates play an important role in biomedical research and testing, and that their use as experimental animals has made a significant contribution to advances in human health and disease control.

The ECG and WHO are committed to maintaining the current diversity of the Order Primates and to ensuring the survival of representative, self-sustaining populations of all species in their natural habitats.

A total of 76 primate taxa are currently considered Endangered, Vulnerable or Rare by the IUCN. Since these taxa are either in serious decline or already at very low and precarious population levels, any exploitation of them threatens their continued survival. Therefore, the ECG and WHO strongly recommend that:

1. Endangered, Vulnerable and Rare species be considered for use in biomedical research only if they are obtained from existing self-sustaining captive breeding colonies i.e. in captive breeding, all animals are required to be at least F2 generation);

2. Species categorized as Status Unknown or Indeterminate also not be considered for use in such research project until adequate data indicate that they are not Endangered, Vulnerable or Rare.

Members of more than 30 species of nonhuman primates, the majority of them wild-caught, are currently being used worldwide in biomedical research and testing. However, sustained yield trapping strategies for wild primates, based on long-term ecological field studies and adequate demographic data, have not yet been developed for any primate species. Continuing habitat loss in most areas where primates occur makes demographic projections difficult and unreliable in most cases. The ECG and WHO therefore recommend that:

1. Wild-caught primates be used primarily for the establishment of self-sustaining captive breeding colonies, the eventual goal of which should be to captive-breed most or all (depending on species) of the primates used in research;

2. Populations of the apparently common primate species be trapped only in:

(a) special management areas where demographic data are available, where the populations are continually monitored to avoid overexploitation, and where sustained yield trapping strategies are being developed and tested;

(b) areas where the animals are living in agricultural or other man-modified environments and have been shown to be agricultural nuisances that would otherwise be destroyed; or

(c) areas where the habitat is already being destroyed, where the primates would otherwise be killed or would die from starvation or stress, and where translocation is not a viable alternative.

To minimize impact on free-living populations, the ECG and WHO urge that trapping, holding and shipping techniques be perfected to the point that accidental death, destruction of habitat, disruption of family groups, and other forms of wastage are kept to an absolute minimum.

The ECG and WHO urge researchers and their funding agencies to assist in the control of international commerce in primates by requiring proper export and import documentation on all animals that they purchase or otherwise obtain, and to refuse animals obtained in contravention of CITES and/or protective legislation in the source countries. 

Allen's Galago xix

Allen's Swamp Monkey $\quad 75$

Alleno pithecus nigroviridis $\quad 75$

Angola Black-\&-White Colobus $\quad$ xx

Angwantibo

Arctocebus calabarensis

Baboon, Chacma

Gelada 33

Guinea xix

Hamadryas 29

Yellow xix

Barbary Macaque $\quad 11$

Bay Colobus $\quad 82$

Black Colobus 103

Black Mangabey 27

Blue Monkey xix

Bonobo 125

Bouvier's Red Colobus $\quad 85$

Bushbaby, Thomas's 3 Zanzibar

CERCOPITHECIDAE Xix

Central Chimpanzee 112

Cercocebus albigenia xix

Cercocebus aterrimus $\quad 27$

Cercocebus atys xix

Cercocebus galeritus xix

C.g. galeritus 21

C.g. "sanjei" 25

Cercocebus torquatus

Cercopithecinae

Cerco pithecus aethio ps

Cerco pithecus albogularis

Cerco pithecus ascanius

Cerco pithecus ce phus

Cerco pithecus diana

Cerco pithecus erythrogaster

Cerco pithecus erythrotis

Cerco pithecus hamlyni

Cerco pithecus lhoesti

Cerco pithecus mitis

Cerco pithecus mona

Cerco pithecus neglectus

Cerco pithecus nictitans

Cerco pithecus petaurista

Cerco pithecus preussi

Cerco pithecus salongo

Cerco pithecus solatus

Chacma Baboon

Chimpanzee

Chimpanzee,Central

Eastern

Pygmy, Dwarf

Western

Collared Mangabey

Colobinae

Colobus angolensis

Colobus guereza

Colobus satanas

Colobus vellerosus
Colobus,Angola Black-\&-White

$\mathrm{xx}$

Bay

Black

Bouvier's Red

Eastern Red

Elliot's Red

Foa Red

Geoffroy's Black-\&-white

Gordon's Red

Iringa

Miss Waldron's Bay

Olive

Oustalet's Red

Pennant's Red

Preuss's Red

Red

Tana River Red

Temminck's Red

Thollon's Red

Uganda Red

Uhehe

Van Beneden's

Western Black-\&-white

Western Red

Zanzibar Red

Crested Mangabey

DeBrazza's Monkey

Diana Guenon or Monkey

Drill

Dwarf Chimpanzee

Dwarf Galago

Eastern Chimpanzee

Eastern Lowland Gorilla

Eastern Red Colobus

Eastern needle-clawed Galago

Elliot's Red Colobus

Erythrocebus patas

Foa Red Colobus

Galaginae

Galago alleni

Galago crassicaudatus

Galago demidovii

Galago elegantulus

Galago garnettii

Galago inustus

Galago senegalensis

Galago thomasi

Galago zanzibaricus

Galago,Allen's

Dwarf

Eastern needle-clawed

Garnett's

Thick-tailed

Thomas's

Western needle-clawed

Zanzibar

Garnett's Galago

Gelada Baboon

Geoffroy's Black-\&-white Colobus

Golden Potto
82

103

85

89

89

89

$\mathrm{xx}$

95

95

80

99

89

85,86

87

79

91

81

89

90

95

99

$\mathrm{xx}$

80

97

xix

xix

45

41

125

xix

115

138

89

xix

89

xix

89

xix

xix

xix

xix

xix

xix

xix

xix

3

7

xix

xix

xix

xix

xix

3

xix

7

xix

33

$\mathrm{xx}$ 
Gordon's Red Colobus 95

Gorilla 133

Gorilla gorilla 133

G.g. berengei $\quad 138$

G.g. graueri 138

G.g. gorilla 134

Gorilla,Eastern Lowland $\quad 138$

Mountain 138

Western Lowland $\quad 134$

Green Monkey

Grey-cheeked Mangabey xix

Guenon,Diana 45

L'Hoest's $\quad 57$

Mountain $\quad 57$

Moustached xix

Owl-faced 53

Preuss's 61

Putty-nosed xix

Red-bellied 69

Red-eared Nose-spotted 69

Red-tailed $\quad$ xix

Russet-eared $\quad 71$

Salongo 49

Sclater's 71

Spot-nosed xix

Sun-tailed 65

White-throated 69

Guereza

Guinea Baboon

Hamadryas Baboon

Iringa Red Colobus

L'Hoest's Guenon

LORISIDAE

Lorisinae

Macaca sylvanus

Macaque, Barbary

Mandrill

Mandrillus leuco phaeus

Mandrillus s phinx

Mangabey,Black

Collared

Crested

Grey-cheeked

Red-capped

Sanje Crested

Smoky

Sooty

Tana River

Mio pithecus talapoin

Miss Waldron's Bay Colobus

Mona Monkey

Monkey,Allen's Swamp

Blue

DeBrazza's

Diana

Green

L'Hoest's

Mona

Mountain

Owl-faced
Patas

Preuss's

Red-bellied

Red-eared Nose-spotted 69

Russet-eared 69

Salongo 49

Sclater's $\quad 71$

Sun-tailed 65

Syke's xix

Mountain Gorilla 138

Mountain Guenon or Monkey $\quad 57$

Moustached Guenon xix

Olive Colobus $\quad 99$

Oustalet's Red Colobus $\quad 89$

Owl-faced Guenon or Monkey 53

Pan paniscus $\quad 125$

Pan troglodytes $\quad 107$

P.t. verus 108

P.t. troglodytes $\quad 112$

P.t. schweinfurthi 115

Papio cynoce phalus xix

Papio hamadryas 29

Papio papio xix

Papio ursinus $\quad$ xix

Patas Monkey xix

Pennant's Red Colobus $\quad 85,86$

Perodicticus potto xix

Pongidae 125

Potto xix

Potto, Golden 1

Preuss's Guenon or Monkey 61

Preuss's Red Colobus $\quad 87$

Procolobus badius superspecies $\quad 79$

P.[b.] badius $\quad 80$

P.[b.]b.badius $\quad 82$

P.[b.] b. temminckii $\quad 81$

P.[b.] b. waldroni $\quad 80$

P.[b.] gordonorum 95

P.[b.] kirkii $\quad 97$

P.[b.] pennanti $\quad 85$

P.[b.] p. pennanti $\quad 86$

P.[b.] p. bouvieri $\quad 85$

P.[b.] p. preussi $\quad 87$

P.[b.] rufomitratus $\quad 89$

P.[b.]r. rufomitratus $\quad 91$

$\begin{array}{ll}P .[b .] r . e l l i o t i & 89\end{array}$

$\begin{array}{ll}\text { P.[b.]r. foai } & 89\end{array}$

$\begin{array}{ll}P .[b .] r . \text { oustaleti } & 89\end{array}$

P.[b.]r. tholloni $\quad 89$

P.[b.] r.tephrosceles $\quad 90$

Procolobus verus 99

Putty-nosed Guenon or Monkey xix

Pygmy Chimpanzee 125

Red Colobus $\quad 79$

Red-bellied Guenon or Monkey 69

Red-capped Mangabey $\quad 17$

Red-eared Nose-spotted Guenon or Monkey $\quad 71$

Red-tailed Guenon or Monkey xix

Russet-eared Guenon or Monkey $\quad 71$

Salongo Guenon or Monkey $\quad 49$ 
Sanje Crested Mangabey $\quad 25$

Sclater's Guenon or Monkey $\quad 71$

Smoky Mangabey 17

Sooty Mangabey xix

Spot-nosed Guenon or Monkey xix

Sun-tailed Guenon or Monkey 65

Swamp Monkey, Allen's 75

Sykes's Monkey xix

Talapoin xix

Tana River Mangabey $\quad 21$

Tana River Red Colobus $\quad 91$

Temminck's Red Colobus $\quad 81$

Thero pithecus gelada 33

Thick-tailed Galago xix

Thollon's Red Colobus $\quad 89$

Thomas's Bushbaby or Galago 3

Uganda Red Colobus 90

Uhehe Red Colobus $\quad 95$

Van Beneden's Colobus 99

Vervet Monkey xix

Western Chimpanzee $\quad 108$

Western Lowland Gorilla $\quad 134$

Western Red Colobus $\quad 80$

Western needle-clawed Galago xix

White-throated Guenon 69

Yellow Baboon xix

Zanzibar Bushbaby or Galago 7

Zanzibar Red Colobus $\quad 97$ 




The primates of Alrica are a diverse and fascmating group of manmals Part of complex communitiens which have existed for milions of years. primates are invaluable to humans for many reasons - aesthetic, scientific, economic. Sadly, many species within the African Continent are now threcitened with extinction. This book focuses on the plight of primates in Africa, and highlights the specific conservation problems facing different species withir their geographic ranges. It also outlines the actions necessary or und rwaty to protect African primates and their habitats.

This book is In the IUCN Red Data Book Series, the authoritaive int $r$ national work that focuses attention on the earth's vanishing wildife

Published by IUCN, Gland, Switzerland and Cambridge. UK with financis support from World Wildlife Fund-US Primate Programme.

Prepared in collaboralion with the United Nalions Environment Programms and the World Wide Fund for Nature.

A CONTRIBUTION TO GEMS

THE GLOBAL ENVIRONMENT MONITORING SYSTEM
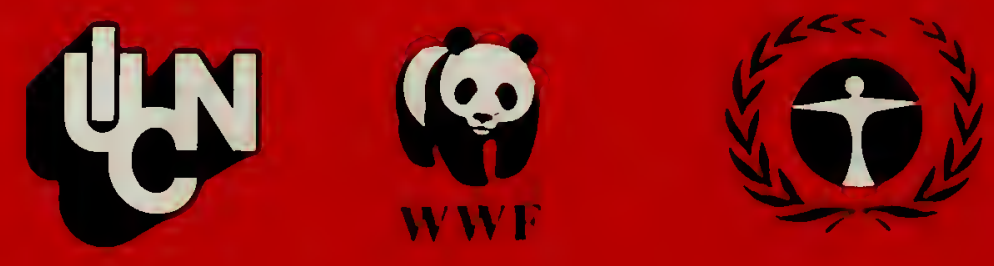

This book is part of

THE IUCN CONSERVATION LIBRARY

for a free copy of the complete catalogue please write to:

Publications Unit

IUCN Con ervation Momioring Centre

219. Huntıngdon Road, Cambridge, CB3 ODL. UK 